\title{
Macrolide inspired macrocycles as modulators of the IL-17A/IL- 17RA interaction
}

Sanja Koštrun ${ }^{1, *}$, Andrea Fajdetić ${ }^{1}$, Dijana Pešić ${ }^{1}$, Karmen Brajša ${ }^{1}$, Vlatka Bencetić Mihaljevići ${ }^{1}$, Dubravko Jelić ${ }^{1}$, Adriana Petrinić Grba ${ }^{1}$, Ivaylo Elenkov ${ }^{1}$, Renata Rupčić ${ }^{1}$, Samra Kapić ${ }^{1}$, Ivana Ozimec Landek ${ }^{1}$, Kristina Butković ${ }^{1}$, Ana Grgičevići ${ }^{1}$, Dinko Žiher ${ }^{1}$, Ana Čikoš ${ }^{1}$, Jasna Padovan ${ }^{1}$, Gordon Saxty' ${ }^{1}$, Kevin Dack ${ }^{2, *}$, Håkan Bladh ${ }^{2}$, Tine SkakNielsen ${ }^{2}$, Simon Feldbaek Nielsen², Maja Lambert ${ }^{2}$, Martin Stahlhut ${ }^{2}$

${ }^{1}$ Fidelta Ltd, Prilaz baruna Filipovića 29, 10000 Zagreb, Croatia;

${ }^{2}$ LEO Pharma A/S, Industriparken 55, 2750 Ballerup, Denmark

KEYWORDS: IL-17A, IL-17 RA, macrocycle, modulator

* Corresponding Authors

Sanja Koštrun, sanja.kostrun@fidelta.eu

Kevin Dack, kdddk@leo-pharma.com

\section{Author Contributions}

These authors contributed equally. 
TABLES

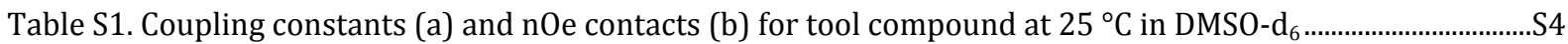

Table S2. List of compounds from Table2 with SMILES notation ....................................................................................S6

Table S3. Supplementary compounds. (prepared according to: (a) Scheme 2; (b) and (c) Scheme 3; (d) and (e) misc....

Table S4. Coupling constants (a), nOe contacts (b), ${ }^{1} \mathrm{H}$ NMR (c) ${ }^{13} \mathrm{C}$ NMR and (d) spectra of compound 4

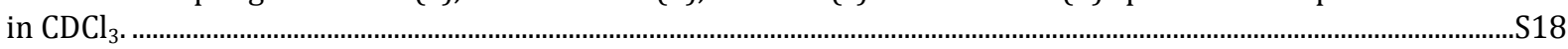

Table S5. Full assignment of compound 4 in buffered $\mathrm{D}_{2} \mathrm{O}$ at $25^{\circ} \mathrm{C}$ as preparation for epitope mapping.............S22

Table S6. Structural properties of most advanced compounds compared with guidelines for macrocyclic compounds. ${ }^{1,2}$.

FIGURES

Figure S1. Schematic presentation of protein binding ELISA biochemical assays, in which (a)

compounds were incubated with IL-17A (ELISA-I) and (b) with IL-17RA (ELISA-II).

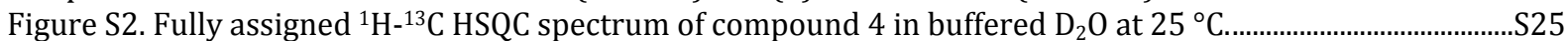

Figure S3. UPLC-MS of compound 4...

Figure S4. UPLC-MS of compound 48. ………………………………………………………………………………...... 22

Figure S5. UPLC-MS of compound 49.

Figure S6. UPLC-MS of compound 56 ....................................................................................................................... 30

Figure S7. Available X-ray structures of IL-17A homodimer in complex with macrocyclic inhibitors: a)

PDB: 5VB9 (magenta) ${ }^{3}$ aligned with PDB: 5HI4 (green) ${ }^{4}$, b) enlarged binding pocket of PDB: 5VB9 ${ }^{3}, c$ )

enlarged binding pocket of PDB: $5 \mathrm{HI} 4^{4}$.

METHODS

NMR METHODS

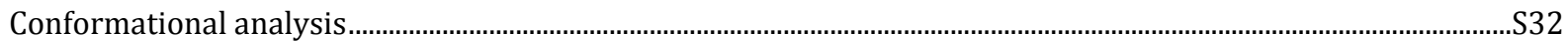

Epitope mapping of compound 4 interacting with human IL-17 …………………………………………………..S32

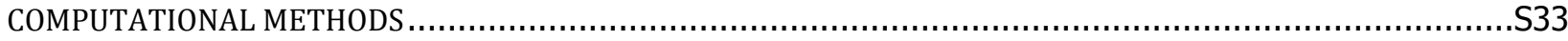

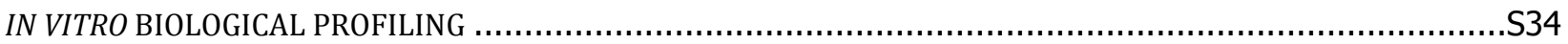

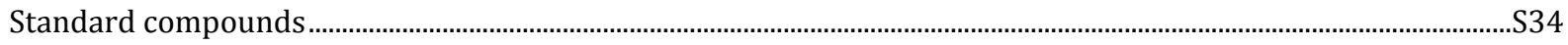

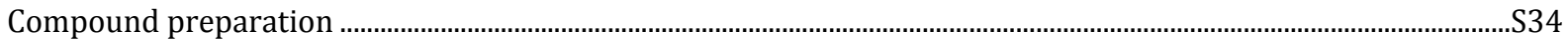

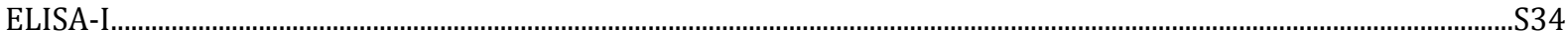

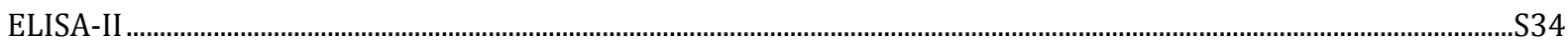

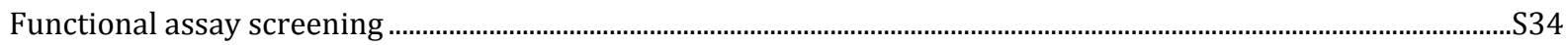

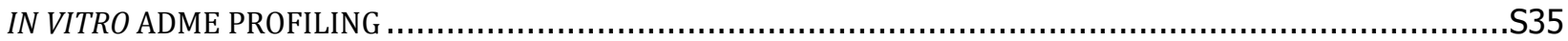

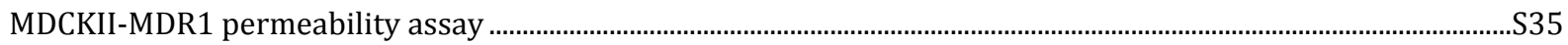

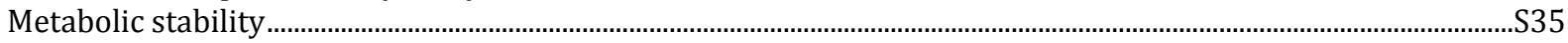

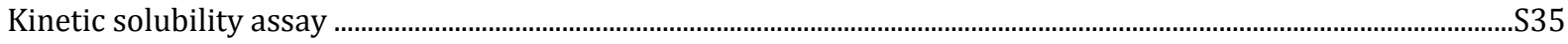

Chromatographic Hydrophobicity Index (CHI)/ChromLogD determination ...............................................................S35

Plasma protein binding.........................................................................................................................................................

CYP3A4 isoform inhibition assay ..............................................................................................................................................S36

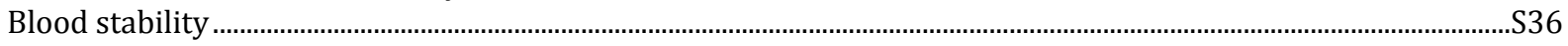

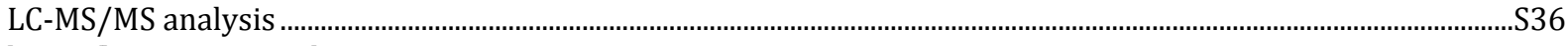

hERG fluorescence polarization assay ………………………………………………………………………………......

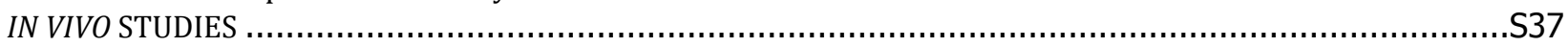

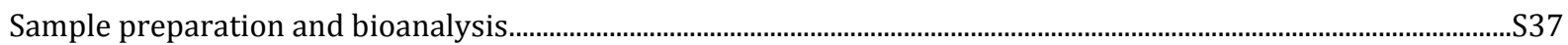

SYHNTHETIC PROCEDURES AND COMPOUND CHARACTERIZATION ................................................

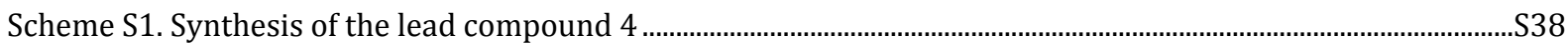

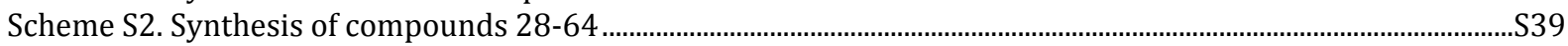

Synthesis of intermediates ........................................................................................................................................... 39

Scheme S3. Preparation of compounds 1-27, 34, 38 and 40 (analogy to synthesis of compound 4) .......................S39

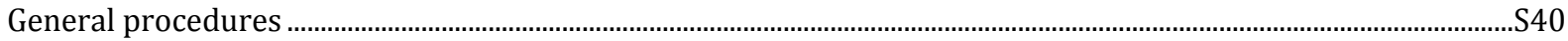

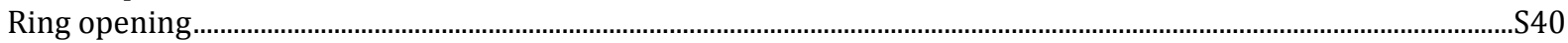

Step 1-Introduction of the first amino acid (synthesis of intermediates C-1a to C-6a) .............................................S40

Step 2 -Introduction of the second amino acid moiety (Scheme S3) ............................................................................S41

Step 3 - Macrocyclisation (synthesis of intermediates D-1-D-21, Scheme S3) ……………………………………......S42

Alternative procedures for the preparation of Intermediates D-7, D-10 and D-11 ……………………………....S42

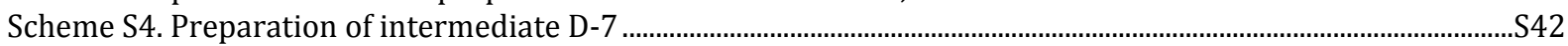


Scheme S5. Synthesis of intermediates D-10 and D-11 .......................................................................................... 44

Step 4a. Side chain modification (reduction of nitro group). Synthesis of intermediates E (Scheme S3) ..............S46

Step 4b. Side chain modification (amidation). Synthesis of intermediates E-1b-E-1g (Scheme S3) .......................S47

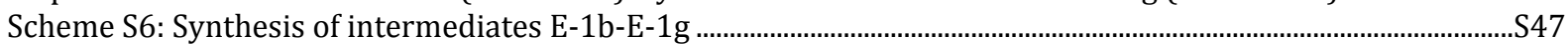

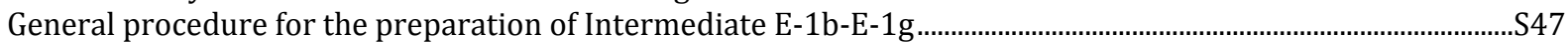

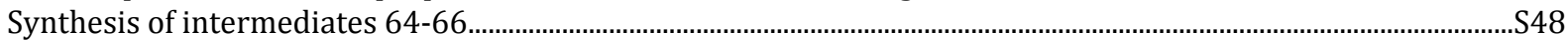

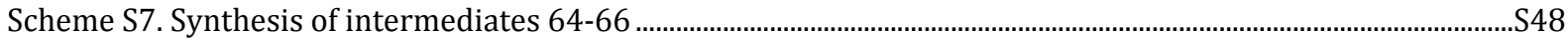

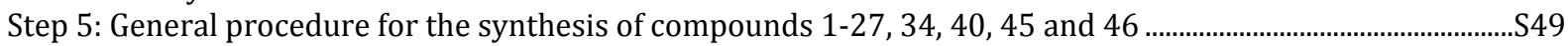

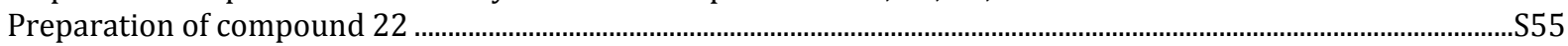

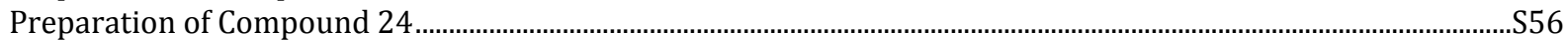

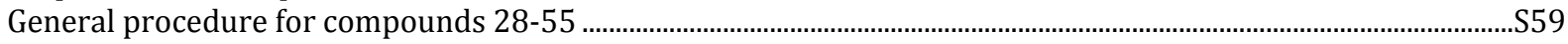

Scheme S8. Synthesis of compounds 28-63

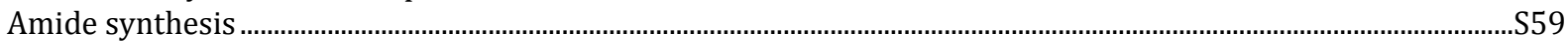

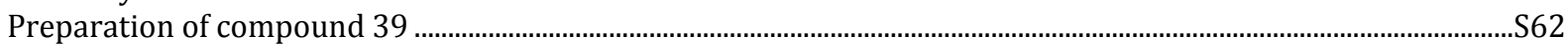

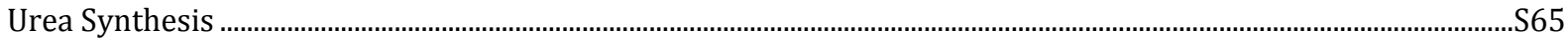

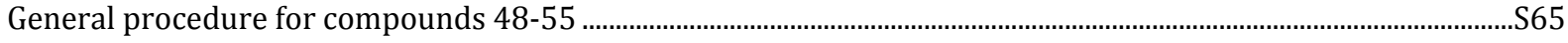

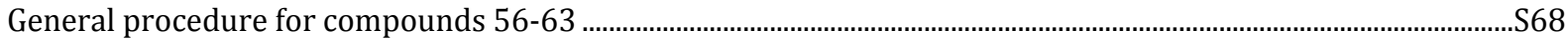

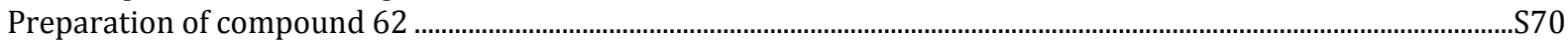

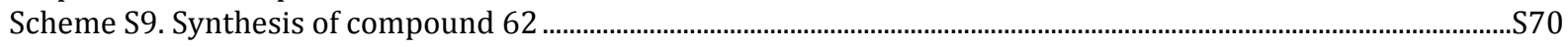

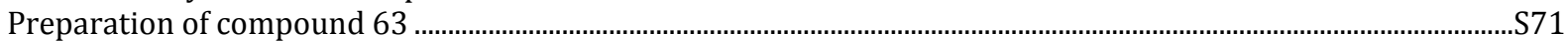

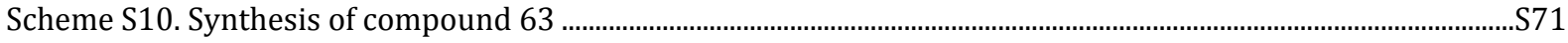

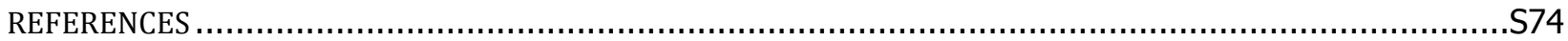




\section{TABLES}

Table S1. Coupling constants (a) and nOe contacts (b) for tool compound at $25^{\circ} \mathrm{C}$ in DMSO-d 6

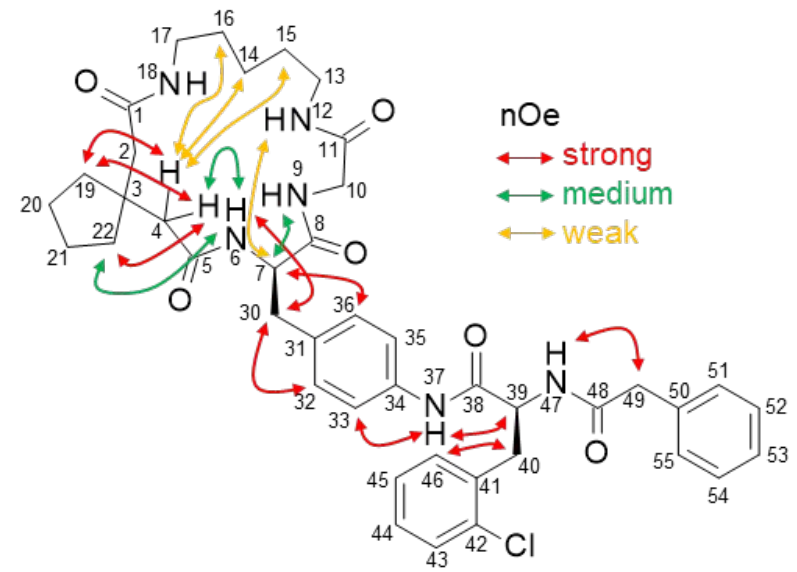

a) Coupling constants

\begin{tabular}{llll}
\hline Protons & xJ/Hz & Protons & xJ/Hz \\
\hline $6 \mathrm{NH}, 7$ & 6.6 & $39,40 \mathrm{~b}$ & 8.7 \\
$7,30 \mathrm{a}$ & 4.0 & $39,47 \mathrm{NH}$ & 8.4 \\
$7,30 \mathrm{~b}$ & 10.9 & 43,44 & 7.9 \\
$9 \mathrm{NH}, 10 \mathrm{a}$ & 6.8 & 43,45 & 1.1 \\
$9 \mathrm{NH}, 10 \mathrm{~b}$ & 5.5 & 44,45 & 7.6 \\
$12 \mathrm{NH}, 13 \mathrm{a}$ & 5.3 & 44,46 & 1.6 \\
$12 \mathrm{NH}, 13 \mathrm{~b}$ & 5.3 & 45,46 & 7.6 \\
13,14 & overlap & $51(55), 52(54)$ & 7.0 \\
$14 ; 15 ; 16$ & overlap & $52(54), 53$ & 7.0 \\
$16,17 \mathrm{a}$ & overlap & $2 \mathrm{a}, 2 \mathrm{~b}$ & 12.7 \\
$16,17 \mathrm{~b}$ & overlap & $4 \mathrm{a}, 4 \mathrm{~b}$ & 12.8 \\
$17 \mathrm{a}, 17 \mathrm{~b} ; 18 \mathrm{NH}$ & $5.7 ; 4.5$ & $10 \mathrm{a}, 10 \mathrm{~b}$ & 16.5 \\
$19 \mathrm{a} ; 20 \mathrm{a}, 20 \mathrm{~b}$ & $7.7 ; 6.1$ & $17 \mathrm{a}, 17 \mathrm{~b}$ & overlap \\
$19 \mathrm{~b} ; 20 \mathrm{a}, 20 \mathrm{~b}$ & $6.6 ; 6.6$ & $19 \mathrm{a}, 19 \mathrm{~b}$ & 12.7 \\
$22 \mathrm{a} ; 21 \mathrm{a}, 21 \mathrm{~b}$ & $7.2 ; 6.6$ & $22 \mathrm{a}, 22 \mathrm{~b}$ & 13.8 \\
$22 \mathrm{~b} ; 21 \mathrm{a}, 21 \mathrm{~b}$ & $8.3 ; 6.1$ & $30 \mathrm{a}, 30 \mathrm{~b}$ & 14.2 \\
20,21 & overlap & $40 \mathrm{a}, 40 \mathrm{~b}$ & 14.2 \\
$35(33), 36(32)$ & 8.4 & $49 \mathrm{a}, 49 \mathrm{~b}$ & 14.1 \\
$39,40 \mathrm{a}$ & 6.1 & & \\
\hline
\end{tabular}


b) nOe correlations






\begin{tabular}{|c|c|c|c|c|c|c|c|c|c|c|c|c|c|}
\hline Cpd \# & SMILES & 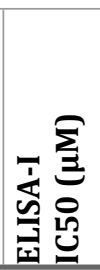 & 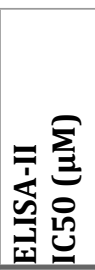 & 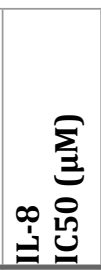 & 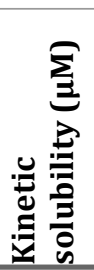 & 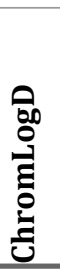 & 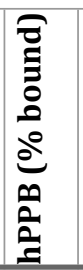 & 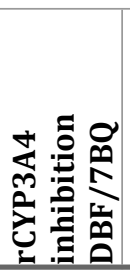 & 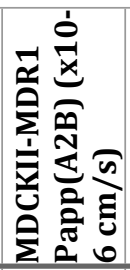 & 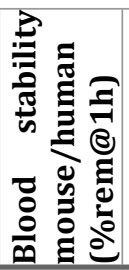 & 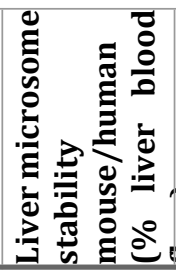 & 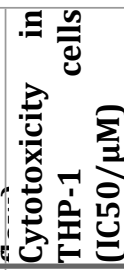 & : \\
\hline 1 & $\begin{array}{l}\mathrm{CO}[\mathrm{C} @] 1(\mathrm{C}) \mathrm{C}[\mathrm{C} @ \mathrm{H}](\mathrm{O}[\mathrm{C} @ \mathrm{H}] 2[\mathrm{C} @ \mathrm{H}](\mathrm{C})[\mathrm{C} @ @ \mathrm{H}](\mathrm{O}[\mathrm{C} @ @ \mathrm{H}] 3 \mathrm{O}[\mathrm{C} @ \mathrm{H}](\mathrm{C}) \mathrm{C}[\mathrm{C} \\
@ @ \mathrm{H}]([\mathrm{C} @ \mathrm{H}] 3 \mathrm{O}) \mathrm{N}(\mathrm{C}) \mathrm{C})[\mathrm{C} @](\mathrm{C})(\mathrm{O}) \mathrm{C}[\mathrm{C} @ \mathrm{H}](\mathrm{C}) \mathrm{CN}(\mathrm{C}) \mathrm{C}(=\mathrm{O}) \mathrm{C}[\mathrm{C} @ \mathrm{H}](\mathrm{Cc} 4 \\
\mathrm{ccc}(\mathrm{NC}(=\mathrm{O})[\mathrm{C} @ \mathrm{H}](\mathrm{Cc} 5 \mathrm{ccccc} 5 \mathrm{Cl}) \mathrm{NC}(=\mathrm{O}) \mathrm{Cc} 6 \mathrm{ccccc} 6) \mathrm{cc} 4) \mathrm{NC}(=\mathrm{O})[\mathrm{C} @ @ \mathrm{H}] 7 \mathrm{CC} \\
\mathrm{C}[\mathrm{C} @ \mathrm{H}] 7 \mathrm{NC}(=\mathrm{O})[\mathrm{C} @ @ \mathrm{H}] 2 \mathrm{C}) \mathrm{C}[\mathrm{C} @ @ \mathrm{H}](\mathrm{C})[\mathrm{C} @ @ \mathrm{H}] 10\end{array}$ & 5.9 & 8.2 & & & & & & & & & & \\
\hline 2 & 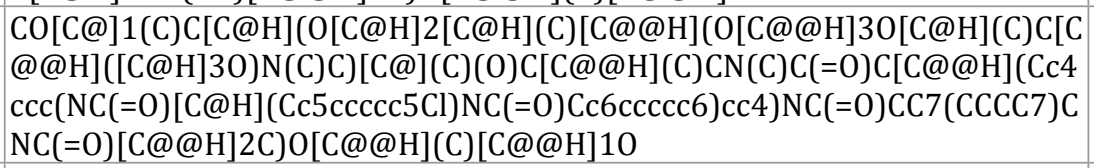 & 6.76 & ND & & & & & & & & & & \\
\hline 3 & 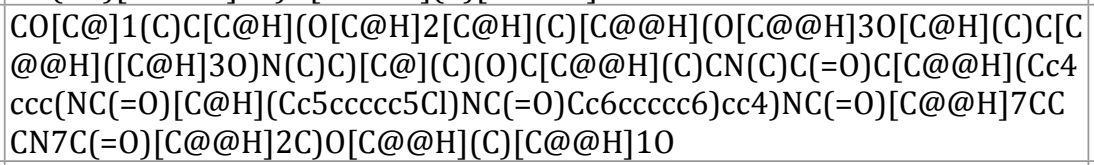 & $>30$ & 6.2 & & & & & & & & & & \\
\hline 4 & $\begin{array}{l}\mathrm{CO}[\mathrm{C} @] 1(\mathrm{C}) \mathrm{C}[\mathrm{C} @ \mathrm{H}](\mathrm{O}[\mathrm{C} @ \mathrm{H}] 2[\mathrm{C} @ \mathrm{H}](\mathrm{C})[\mathrm{C} @ @ \mathrm{H}](\mathrm{O}[\mathrm{C} @ @ \mathrm{H}] 3 \mathrm{O}[\mathrm{C} @ \mathrm{H}](\mathrm{C}) \mathrm{C}[\mathrm{C} \\
@ \mathrm{H}]([\mathrm{C} @ \mathrm{H}] 3 \mathrm{O}) \mathrm{N}(\mathrm{C}) \mathrm{C})[\mathrm{C} @](\mathrm{C})(\mathrm{O}) \mathrm{C}[\mathrm{C} @ \mathrm{H}](\mathrm{C}) \mathrm{CN}(\mathrm{C}) \mathrm{C}=\mathrm{O}) \mathrm{C}[\mathrm{C} @ \mathrm{H}](\mathrm{Cc} 4 \\
\mathrm{ccc}(\mathrm{NC}(=\mathrm{O})[\mathrm{C} @ \mathrm{H}](\mathrm{Cc} 5 \mathrm{cccc} 5 \mathrm{Cl}) \mathrm{NC}(=\mathrm{O}) \mathrm{Cc} 6 \mathrm{ccccc}) \mathrm{cc} 4) \mathrm{NC}(=\mathrm{O})[\mathrm{C} @ \mathrm{H}](\mathrm{NC} \\
=0)[\mathrm{C} @ @ \mathrm{H}] 2 \mathrm{C}) \mathrm{C}(\mathrm{C}) \mathrm{C}) \mathrm{C}[\mathrm{C} @ @ \mathrm{H}](\mathrm{C})[\mathrm{C} @ @ \mathrm{H}] 10\end{array}$ & 0.170 & 0.113 & 0.556 & $10-30$ & 4.4 & 94.2 & $29 / 26$ & 0.8 & $1 / 100$ & $78 / 44$ & $>30$ & $>10$ \\
\hline 5 & $\begin{array}{l}\mathrm{CO}[\mathrm{C} @] 1(\mathrm{C}) \mathrm{C}[\mathrm{C} @ \mathrm{H}](\mathrm{O}[\mathrm{C} @ \mathrm{H}] 2[\mathrm{C} @ \mathrm{H}](\mathrm{C})[\mathrm{C} @ @ \mathrm{H}](\mathrm{O}[\mathrm{C} @ @ \mathrm{H}] 3 \mathrm{O}[\mathrm{C} @ \mathrm{H}](\mathrm{C}) \mathrm{C}[\mathrm{C} \\
@ @ \mathrm{H}]([\mathrm{C} @ \mathrm{H}] 3 \mathrm{O}) \mathrm{N}(\mathrm{C}) \mathrm{C})[\mathrm{C} @](\mathrm{C})(\mathrm{O}) \mathrm{C}[\mathrm{C} @ \mathrm{H}](\mathrm{C}) \mathrm{CN}(\mathrm{C}) \mathrm{C}(=\mathrm{O}) \mathrm{C}[\mathrm{C} @ \mathrm{H}](\mathrm{Cc} 4 \\
\mathrm{ccc}(\mathrm{NC}(=\mathrm{O})[\mathrm{C} @ \mathrm{H}](\mathrm{Cc} 5 \mathrm{cccc} 5 \mathrm{Cl}) \mathrm{NC}(=\mathrm{O}) \mathrm{Cc} 6 \mathrm{cccc} 6) \mathrm{cc} 4) \mathrm{NC}(=\mathrm{O})[\mathrm{C} @ \mathrm{H}](\mathrm{NC}= \\
0)[\mathrm{C} @ @ \mathrm{H}] 2 \mathrm{C}) \mathrm{C}(\mathrm{C}) \mathrm{C}) \mathrm{O}[\mathrm{C} @ @ \mathrm{H}](\mathrm{C})[\mathrm{C} @ @ \mathrm{H}] 10\end{array}$ & $>30$ & & & & & & & & & & & \\
\hline 6 & 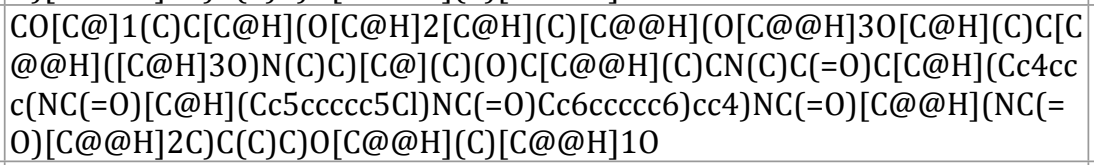 & $>30$ & & & & & & & & & & & \\
\hline 7 & $\begin{array}{l}\mathrm{CO}[\mathrm{C} @] 1(\mathrm{C}) \mathrm{C}[\mathrm{C} @ \mathrm{H}](\mathrm{O}[\mathrm{C} @ \mathrm{H}] 2[\mathrm{C} @ \mathrm{H}](\mathrm{C})[\mathrm{C} @ @ \mathrm{H}](\mathrm{O}[\mathrm{C} @ @ \mathrm{H}] 3 \mathrm{O}[\mathrm{C} @ \mathrm{H}](\mathrm{C}) \mathrm{C}[\mathrm{C} \\
@ @ \mathrm{H}]([\mathrm{C} @ \mathrm{H}] 3 \mathrm{O}) \mathrm{N}(\mathrm{C}) \mathrm{C})[\mathrm{C} @](\mathrm{C})(\mathrm{O}) \mathrm{C}[\mathrm{C} @ \mathrm{H}](\mathrm{C}) \mathrm{CN}(\mathrm{C}) \mathrm{C}=\mathrm{O}) \mathrm{C}[\mathrm{C} @ \mathrm{H}](\mathrm{Cc} 4 \mathrm{cc} \\
\mathrm{c}(\mathrm{NC}(=\mathrm{O})[\mathrm{C} @ \mathrm{H}](\mathrm{Cc} 5 \mathrm{cccc} 5 \mathrm{Cl}) \mathrm{NC}(=\mathrm{O}) \mathrm{Cc} 6 \mathrm{cccc} 6) \mathrm{cc} 4) \mathrm{NC}(=\mathrm{O})[\mathrm{C} @ \mathrm{H}](\mathrm{NC}(=\mathrm{O})[ \\
\mathrm{C} @ \mathrm{H}] 2 \mathrm{C}) \mathrm{C}(\mathrm{C}) \mathrm{C}) \mathrm{O}[\mathrm{C} @ @ \mathrm{H}](\mathrm{C})[\mathrm{C} @ @ \mathrm{H}] 10\end{array}$ & $>30$ & & & & & & & & & & & \\
\hline 8 & $\begin{array}{l}\mathrm{CO}[\mathrm{C} @] 1(\mathrm{C}) \mathrm{C}[\mathrm{C} @ \mathrm{H}](\mathrm{O}[\mathrm{C} @ \mathrm{H}] 2[\mathrm{C} @ \mathrm{H}](\mathrm{C})[\mathrm{C} @ @ \mathrm{H}](\mathrm{O}[\mathrm{C} @ @ \mathrm{H}] 3 \mathrm{O}[\mathrm{C} @ \mathrm{H}](\mathrm{C}) \mathrm{C}[\mathrm{C} \\
@ @ \mathrm{H}]([\mathrm{C} @ \mathrm{H}] 3 \mathrm{O}) \mathrm{N}(\mathrm{C}) \mathrm{C})[\mathrm{C} @](\mathrm{C})(\mathrm{O}) \mathrm{C}[\mathrm{C} @ \mathrm{H}](\mathrm{C}) \mathrm{CN}(\mathrm{C}) \mathrm{C}=\mathrm{O}) \mathrm{C}[\mathrm{C} @ \mathrm{H}](\mathrm{Cc} 4 \\
\mathrm{ccc}(\mathrm{NC}(=\mathrm{O})[\mathrm{C} @ \mathrm{H}](\mathrm{Cc} 5 \mathrm{cccc} 5 \mathrm{Cl}) \mathrm{NC}(=\mathrm{O}) \mathrm{Cc} 6 \mathrm{ccccc}) \mathrm{cc} 4) \mathrm{NC}(=\mathrm{O})[\mathrm{C} @ \mathrm{H}](\mathrm{C}) \mathrm{NC}( \\
=0)[\mathrm{C} @ @ \mathrm{H}] 2 \mathrm{C}) \mathrm{C}[\mathrm{C} @ @ \mathrm{H}](\mathrm{C})[\mathrm{C} @ @ \mathrm{H}] 10\end{array}$ & 15 & & & & & & & & & & & \\
\hline
\end{tabular}


Cpd \# SMILES

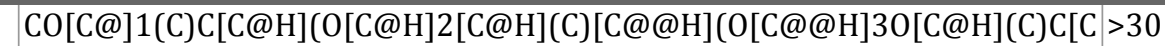
@@H]([C@H]3O)N(C)C)[C@](C)(O)C[C@@H](C)CN(C)C(=O)C[C@ @H](Cc4 $\operatorname{ccc}(\mathrm{NC}(=0)[\mathrm{C} @ \mathrm{H}](\mathrm{Cc} 5 \operatorname{ccccc} 5 \mathrm{Cl}) \mathrm{NC}(=0) \mathrm{Cc} 6 \operatorname{ccccc} 6) \operatorname{cc} 4) \mathrm{NC}(=0)[\mathrm{C} @ @ \mathrm{H}](\mathrm{C}) \mathrm{N}$ $\mathrm{C}(=0)[\mathrm{C} @ \mathrm{H}] 2 \mathrm{C}) \mathrm{O}[\mathrm{C} @ @ \mathrm{H}](\mathrm{C})[\mathrm{C} @ @ \mathrm{H}] 10$

10 CO[C@]1(C)C[C@H](O[C@H]2[C@H](C)[C@@H]COC@@@]3O[C@H](C)C[C 12.6 @@H]([C@H]30)N(C)C)[C@](C)(O)C[C@@H](C)CN(C)C $=0) C[C @ @ H](C c 4$ $\operatorname{ccc}(\mathrm{NC}(=0)[\mathrm{C} @ \mathrm{H}](\mathrm{Cc} 5 \operatorname{ccccc} 5 \mathrm{Cl}) \mathrm{NC}(=0) \mathrm{Cc} 6 \operatorname{ccccc} 6) \operatorname{cc} 4) \mathrm{NC}(=0)[\mathrm{C} @ \mathrm{H}](\mathrm{CC}(\mathrm{C})$ C)NC(=0)[C@@H]2C)O[C@@H](C)[C@@H]10

11 CC[C@H](C)[C@@H]1NC(=0)[C@H](C)[C@@ $@ H](\mathrm{O}[\mathrm{C} @ H] 2 \mathrm{C}[\mathrm{C} @ @](\mathrm{C})(\mathrm{OC})[2.6$ $\mathrm{C} @ \mathrm{H}](\mathrm{O})[\mathrm{C} @ \mathrm{H}](\mathrm{C}) \mathrm{O} 2)[\mathrm{C} @ \mathrm{H}](\mathrm{C})[\mathrm{C} @ @ \mathrm{H}](\mathrm{O}[\mathrm{C} @ @ \mathrm{H}] 3 \mathrm{O}[\mathrm{C} @ \mathrm{H}] \mathrm{C}) \mathrm{C}[\mathrm{C} @ \mathrm{H}$ ]$([\mathrm{C} @ \mathrm{H}] 30) \mathrm{N}(\mathrm{C}) \mathrm{C})[\mathrm{C} @](\mathrm{C})(\mathrm{O}) \mathrm{C}[\mathrm{C} @ @ \mathrm{H}](\mathrm{C}) \mathrm{CN}(\mathrm{C}) \mathrm{C}(=\mathrm{O}) \mathrm{C}[\mathrm{C} @ @ \mathrm{H}](\mathrm{Cc} 4 \mathrm{ccc}(\mathrm{N}$ $\mathrm{C}(=0)[\mathrm{C} @ \mathrm{H}](\mathrm{Cc} 5 \mathrm{ccccc} 5 \mathrm{Cl}) \mathrm{NC}(=0) \mathrm{Cc} 6 \mathrm{ccccc} 6) \mathrm{cc} 4) \mathrm{NC} 1=0$

$12 \mathrm{CO}[\mathrm{C} @] 1(\mathrm{C}) \mathrm{C}[\mathrm{C} @ \mathrm{H}](\mathrm{O}[\mathrm{C} @ \mathrm{H}] 2[\mathrm{C} @ \mathrm{H}](\mathrm{C})[\mathrm{C} @ \mathrm{H}](\mathrm{O}[\mathrm{C} @ @ \mathrm{C}] 3 \mathrm{O}[\mathrm{C} @ \mathrm{H}](\mathrm{C}) \mathrm{C}[\mathrm{C} 1.6$ @@H]([C@H]3O)N(C)C)[C@](C)(O)C[C@@H](C)CN(C)C(=O)C[C@H](Cc4cc $\mathrm{c}(\mathrm{NC}(=0)[\mathrm{C} @ \mathrm{H}](\mathrm{Cc} 5 \mathrm{ccccc} 5 \mathrm{Cl}) \mathrm{NC}(=0) \mathrm{Cc} 6 \mathrm{ccccc} 6) \mathrm{cc} 4) \mathrm{NC}(=0)[\mathrm{C} @ @ \mathrm{H}](\mathrm{NC}=$ 0)[C@@H]2C)C(C)(C)C)O[C@@H](C)[C@@H]10

13 CO[C@]1(C)C[C@H](O[C@H]2[C@H](C)[C@ @H](O[C@@ $@ 30[\mathrm{C} @ H](C) C[C 2.62$ @@H]([C@H]30)N(C)C)[C@](C)(O)C[C@@H](C)CN(C)C(=0)C[C@OH](Cc4 $\operatorname{ccc}(\mathrm{NC}(=))[\mathrm{C} @ \mathrm{H}](\mathrm{Cc} 5 \operatorname{ccccc} 5 \mathrm{Cl}) \mathrm{NC}(=0) \mathrm{Cc} 6 \mathrm{ccccc} 6) \operatorname{cc} 4) \mathrm{NC}(=0)[\mathrm{C} @ @ \mathrm{H}](\mathrm{NC}($ $=0)[\mathrm{C} @ @ H] 2 \mathrm{C}) \mathrm{C7CC} 7) \mathrm{O}[\mathrm{C} @ @ \mathrm{H}](\mathrm{C})[\mathrm{C} @ @ \mathrm{H}] 10$

$14 \mathrm{CO}[\mathrm{C} @] 1(\mathrm{C}) \mathrm{C}[\mathrm{C} @ \mathrm{H}](\mathrm{O}[\mathrm{C} @ \mathrm{H}] 2[\mathrm{C} @ \mathrm{H}](\mathrm{C})[\mathrm{C} @ @ \mathrm{H}](\mathrm{O}[\mathrm{C} @ @ \mathrm{H}] 3 \mathrm{O}[\mathrm{C} @ \mathrm{H}](\mathrm{C}) \mathrm{C}[\mathrm{C} 0.256$ @@H]([C@H]30)N(C)C)[C@](C)(O)C[C@@H](C)CN(C)C $(=0)[\mathrm{C} @ H](\mathrm{NC}(=\mathrm{O}$ ) $\mathrm{C}[\mathrm{C} @ \mathrm{H}](\mathrm{Cc} 4 \operatorname{ccc}(\mathrm{NC}(=0)[\mathrm{C} @ \mathrm{H}](\mathrm{Cc} 5 \operatorname{ccccc} 5 \mathrm{Cl}) \mathrm{NC}(=0) \mathrm{Cc} 6 \operatorname{ccccc} 6) \mathrm{cc} 4) \mathrm{NC}(=0)$ [C@@H]2C)C(C)C)O[C@@H](C)[C@@H]10

15 CO[C@]1(C)C[C@H](O[C@H]2[C@H](C)[C@@ $0 \mathrm{H}](\mathrm{O}[\mathrm{C} @ @ H] 30[\mathrm{C} @ H](\mathrm{C}) \mathrm{C}[\mathrm{C}>30$ @@H]([C@H]3O)N(C)C)[C@](C)(O)C[C@@H](C)CN(C)C(=0)[C@H](NC(=O )C[C@@H] $(\mathrm{Cc} 4 \operatorname{ccc}(\mathrm{NC}(=0)[\mathrm{C} @ \mathrm{H}](\mathrm{Cc} 5 \operatorname{ccccc} 5 \mathrm{Cl}) \mathrm{NC}(=0) \mathrm{Cc} 6 \operatorname{ccccc} 6) \mathrm{cc} 4) \mathrm{NC}(=$ $0)[\mathrm{C} @ @ \mathrm{H}] 2 \mathrm{C}) \mathrm{C}(\mathrm{C}) \mathrm{C}) \mathrm{O}[\mathrm{C} @ @ \mathrm{H}](\mathrm{C})[\mathrm{C} @ @ \mathrm{H}] 10$

16 CO[C@]1(C)C[C@H](O[C@H]2[C@H](C)[C@@ $@$ H] $(\mathrm{O}[\mathrm{C} @ @ H] 30[\mathrm{C} @ H](\mathrm{C}) \mathrm{C}[\mathrm{C}>30$ $@ @ \mathrm{H}]([\mathrm{C} @ \mathrm{H}] 30) \mathrm{N}(\mathrm{C}) \mathrm{C})[\mathrm{C} @](\mathrm{C})(\mathrm{O}) \mathrm{C}[\mathrm{C} @ @ \mathrm{H}](\mathrm{C}) \mathrm{CN}(\mathrm{C}) \mathrm{C}(=\mathrm{O})[\mathrm{C} @ @ \mathrm{H}] \mathrm{NC}(=$ $0) \mathrm{C}[\mathrm{C} @ \mathrm{H}](\mathrm{Cc} 4 \mathrm{ccc}(\mathrm{NC}(=))[\mathrm{C} @ \mathrm{H}](\mathrm{Cc} 5 \operatorname{ccccc} 5 \mathrm{Cl}) \mathrm{NC}(=0) \mathrm{Cc} 6 \mathrm{ccccc} 6) \operatorname{cc} 4) \mathrm{NC}(=$ 0)[C@@H]2C)C(C)C)O[C@@H](C)[C@@H]10

17 CO[C@]1(C)C[C@H](O[C@H]2[C@H](C)[C@@H](O[C@@ $@ @ \mathrm{H}]([\mathrm{C} @ \mathrm{H}] 30) \mathrm{N}(\mathrm{C}) \mathrm{C})[\mathrm{C} @](\mathrm{C})(\mathrm{O}) \mathrm{C}[\mathrm{C} @ @ \mathrm{H}](\mathrm{C}) \mathrm{CN}(\mathrm{C}) \mathrm{C}(=\mathrm{O})[\mathrm{C} @ \mathrm{H}](\mathrm{NC}=$ 
Cpd \# SMILES

0)C[C@@ $@$ H](Cc4ccc( $\mathrm{NC}(=0)[\mathrm{C} @ \mathrm{H}](\mathrm{Cc} 5 \operatorname{ccccc} 5 \mathrm{Cl}) \mathrm{NC}(=0) \mathrm{Cc} 6 \mathrm{ccccc} 6) \mathrm{cc} 4) \mathrm{NC}($

$=0)[\mathrm{C} @ @ \mathrm{H}] 2 \mathrm{C}) \mathrm{C}(\mathrm{C}) \mathrm{C}) \mathrm{O}[\mathrm{C} @ @ \mathrm{H}](\mathrm{C})[\mathrm{C} @ @ \mathrm{H}] 10$

18 CO[C@]1(C)C[C@H](O[C@H]2[C@H](C)[C@@H](O[C@@ $@ 30[\mathrm{C} @ H](C) C[C ~>30$ @@H]([C@H]3O)N(C)C)[C@](C)(O)C[C@@H](C)CN(C)C(=O)[C@@H](Cc4c $\operatorname{cc}(\mathrm{NC}(=0)[\mathrm{C} @ \mathrm{H}](\mathrm{Cc} 5 \operatorname{ccccc} 5 \mathrm{Cl}) \mathrm{NC}(=0) \mathrm{Cc} 6 \mathrm{ccccc} 6) \operatorname{cc} 4) \mathrm{NC}(=0) \mathrm{C}[\mathrm{C} @ \mathrm{H}](\mathrm{NC}=$ 0)[C@@H]2C)C(C)C)O[C@@H](C)[C@@H]10

$19 \mathrm{CO}[\mathrm{C} @] 1(\mathrm{C}) \mathrm{C}[\mathrm{C} @ \mathrm{H}](\mathrm{O}[\mathrm{C} @ \mathrm{H}] 2[\mathrm{C} @ \mathrm{H}](\mathrm{C})[\mathrm{C} @ @ \mathrm{H}](\mathrm{O}[\mathrm{C} @ @ \mathrm{H}] 3 \mathrm{O}[\mathrm{C} @ \mathrm{H}](\mathrm{C}) \mathrm{C}[\mathrm{C}>30$ @@H]([C@H]30)N(C)C)[C@](C)(O)C[C@@H](C)CN(C)C(=0)[C@@H](Cc4c $\operatorname{cc}(\mathrm{NC}(=0)[\mathrm{C} @ \mathrm{H}](\mathrm{Cc} 5 \operatorname{ccccc} 5 \mathrm{Cl}) \mathrm{NC}(=0) \mathrm{Cc} 6 \mathrm{ccccc} 6) \mathrm{cc} 4) \mathrm{NC}(=0) \mathrm{C}[\mathrm{C} @ @ \mathrm{H}](\mathrm{NC}($ $=0)[\mathrm{C} @ @ H] 2 \mathrm{C}) \mathrm{C}(\mathrm{C}) \mathrm{C}) \mathrm{O}[\mathrm{C} @ \mathrm{H}](\mathrm{C})[\mathrm{C} @ @ \mathrm{H}] 10$

20 CO[C@]1(C)C[C@H](O[C@H]2[C@H](C)[C@@H](O[C@@H]3O[C@H](C)C[C >30 $@ @ \mathrm{H}]([\mathrm{C} @ \mathrm{H}] 30) \mathrm{N}(\mathrm{C}) \mathrm{C})[\mathrm{C} @](\mathrm{C})(\mathrm{O}) \mathrm{C}[\mathrm{C} @ @ \mathrm{H}](\mathrm{C}) \mathrm{CN}(\mathrm{C}) \mathrm{C}(=\mathrm{C})[\mathrm{C} @ @ \mathrm{H}](\mathrm{Cc} 4 \mathrm{c}$ $\operatorname{cc}(\mathrm{NC}(=0)[\mathrm{C} @ \mathrm{H}](\mathrm{Cc} 5 \operatorname{ccccc} 5 \mathrm{Cl}) \mathrm{NC}(=0) \mathrm{Cc} 6 \operatorname{ccccc} 6) \mathrm{cc} 4) \mathrm{NC}(=0)[\mathrm{C} @ \mathrm{H}](\mathrm{CNC}(=$ 0)[C@@

21 CO[C@]1(C)C[C@H](O[C@H]2[C@H](C)[C@@H](O[C@@H]3O[C@H](C)C[C 1.4 $@ @ \mathrm{H}]([\mathrm{C} @ \mathrm{H}] 3 \mathrm{O}) \mathrm{N}(\mathrm{C}) \mathrm{C})[\mathrm{C} @](\mathrm{C})(\mathrm{O}) \mathrm{C}[\mathrm{C} @ @ \mathrm{H}](\mathrm{C}) \mathrm{CN}(\mathrm{C}) \mathrm{C}(=\mathrm{O})[\mathrm{C} @ \mathrm{H}](\mathrm{Cc} 4 \mathrm{ccc}$ $(\mathrm{NC}(=0)[\mathrm{C} @ \mathrm{H}](\mathrm{Cc} 5 \mathrm{ccccc} 5 \mathrm{Cl}) \mathrm{NC}(=0) \mathrm{Cc} 6 \mathrm{ccccc} 6) \mathrm{cc} 4) \mathrm{NC}(=0)[\mathrm{C} @ \mathrm{H}](\mathrm{NC}(=\mathrm{O})[$ $\mathrm{C} @ \mathrm{H}] 2 \mathrm{C}) \mathrm{C}(\mathrm{C}) \mathrm{C}) \mathrm{O}[\mathrm{C} @ @ \mathrm{H}](\mathrm{C})[\mathrm{C} @ @ \mathrm{H}] 10$

22 CO[C@]1(C)C[C@H](O[C@H]2[C@H](C)[C@@H](O[C@@ $@ 30[\mathrm{C} @ H](\mathrm{C}) \mathrm{C}[\mathrm{C} 15.9$ @@H]([C@H]3O)N(C)C)[C@](C)(O)C[C@@H](C)CN(C)C $=0)[C @ H](N C=$ 0)C[C@@H](Cc4ccc( $\mathrm{NC}(=0)[\mathrm{C} @ \mathrm{H}](\mathrm{Cc} 5 \operatorname{ccccc} 5 \mathrm{Cl}) \mathrm{NC}(=0) \mathrm{Cc} 6 \mathrm{ccccc} 6) \mathrm{cc} 4) \mathrm{NC}($ $=0)[\mathrm{C} @ @ H] 2 \mathrm{C}) \mathrm{C}(\mathrm{C}) \mathrm{C}) \mathrm{O}[\mathrm{C} @ @ \mathrm{H}](\mathrm{C})[\mathrm{C} @ @ \mathrm{H}] 10$

23 CO[C@]1(C)C[C@H](O[C@H]2[C@H](C)[C@@H](O[C@@ $0 \mathrm{H}] 3 \mathrm{O}[\mathrm{C} @ H](\mathrm{C}) \mathrm{C}[\mathrm{C}>30$ @@H]([C@H]3O)N(C)C)[C@](C)(O)C[C@@H](C)CN(C)C(=O)C[C@@H](Cc4 $\operatorname{ccc}(\mathrm{NC}(=0)[\mathrm{C} @ \mathrm{H}](\mathrm{Cc} 5 \mathrm{ccccc} 5 \mathrm{Cl}) \mathrm{NC}(=0) \mathrm{Cc} 6 \mathrm{ccccc} 6) \operatorname{cc} 4) \mathrm{NC}(=0) \mathrm{C}[\mathrm{C} @ @ \mathrm{H}](\mathrm{NC}$ $(=0)[\mathrm{C} @ @ \mathrm{H}] 2 \mathrm{C}) \mathrm{C}(\mathrm{C}) \mathrm{C}) \mathrm{O}[\mathrm{C} @ @ \mathrm{H}](\mathrm{C})[\mathrm{C} @ @ \mathrm{H}] 10$

24 CO[C@]1(C)C[C@H](O[C@H]2[C@H](C)[C@@H](O[C@@ $@ 30[\mathrm{C} @ H](C) C[C 24.8$ $@ @ \mathrm{H}]([\mathrm{C} @ \mathrm{H}] 30) \mathrm{N}(\mathrm{C}) \mathrm{C})[\mathrm{C} @](\mathrm{C})(\mathrm{O}) \mathrm{C}[\mathrm{C} @ @ \mathrm{H}](\mathrm{C}) \mathrm{CN}(\mathrm{C}) \mathrm{C}(=\mathrm{O}) \mathrm{C}[\mathrm{C} @ @ \mathrm{H}](\mathrm{Cc} 4$ $\operatorname{ccc}(\mathrm{NC}(=))[\mathrm{C} @ \mathrm{H}](\mathrm{Cc} 5 \operatorname{ccccc} 5 \mathrm{Cl}) \mathrm{NC}(=0) \mathrm{Cc} 6 \operatorname{ccccc} 6) \operatorname{cc} 4) \mathrm{NC}(=0)[\mathrm{C} @ \mathrm{H}](\mathrm{CNC}($ $=0)[C @ @] 2 C) C(C) C) O[C @ @](C)[C @ @ H] 10$

$25 \mathrm{CO}[\mathrm{C} @] 1(\mathrm{C}) \mathrm{C}[\mathrm{C} @ \mathrm{H}](\mathrm{O}[\mathrm{C} @ \mathrm{H}] 2[\mathrm{C} @ \mathrm{H}](\mathrm{C})[\mathrm{C} @ @ \mathrm{H}](\mathrm{O}[\mathrm{C} @ @ \mathrm{H}] 3 \mathrm{O}[\mathrm{C} @ \mathrm{H}](\mathrm{C}) \mathrm{C}[\mathrm{C} 2.9$ @@H]([C@H]3O)N(C)C)[C@](C)(O)C[C@@H](C)CN(C)C(=O)C[C@@H](Cc4 $\operatorname{ccc}(\mathrm{NC}(=0)[\mathrm{C} @ \mathrm{H}](\mathrm{Cc} 5 \operatorname{ccccc} 5 \mathrm{Cl}) \mathrm{NC}(=0) \mathrm{Cc} 6 \operatorname{ccccc} 6) \operatorname{cc} 4) \mathrm{NC}(=0)[\mathrm{C} @ @ \mathrm{H}](\mathrm{CNC}$ $(=0)[C @ H] 2 C) C(C) C) O[C @ H](C)[C @ @ H] 10$ 
Cpd \# SMILES @@H]([C@H]30)N(C)C)[C@](C)(O)C[C@@H](C)CN(C)C(=O)C[C@@] Cc4 $\operatorname{ccc}(\mathrm{NC}(=0)[\mathrm{C} @ \mathrm{H}](\mathrm{Cc} 5 \mathrm{ccccc} 5 \mathrm{Cl}) \mathrm{NC}(=0) \mathrm{Cc} 6 \mathrm{ccccc} 6) \mathrm{cc} 4) \mathrm{NC}(=0) \mathrm{C}[\mathrm{C} @ @ \mathrm{H}](\mathrm{CC}$ (C)C)NC(=0)[C@@H]2C)O[C@@H](C)[C@@H]10

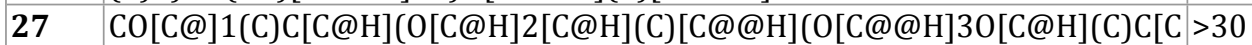
@@H]([C@H]30)N(C)C)[C@](C)(O)C[C@@H](C)CN(C)C(=O)C[C@@] Cc4 $\operatorname{ccc}(\mathrm{NC}(=0)[\mathrm{C} @ \mathrm{H}](\mathrm{Cc} 5 \operatorname{ccccc} 5 \mathrm{Cl}) \mathrm{NC}(=0) \mathrm{Cc} 6 \operatorname{ccccc} 6) \operatorname{cc} 4) \mathrm{NC}(=0) \mathrm{CCNC}(=0)[\mathrm{C}$ @@H]2C)0[C@@ $](\mathrm{C})[\mathrm{C} @ @ H] 10$

28 COc1ccc $(\operatorname{cc} 1) \mathrm{C}(=\mathrm{O}) \mathrm{N}[\mathrm{C} @ @ \mathrm{H}](\mathrm{Cc} 2 \mathrm{ccccc} 2 \mathrm{Cl}) \mathrm{C}(=\mathrm{O}) \mathrm{Nc} 3 \operatorname{ccc}(\mathrm{C}[\mathrm{C} @ @ \mathrm{H}] 4 \mathrm{CC}(=0) 0.397$ $\mathrm{N}(\mathrm{C}) \mathrm{C}[\mathrm{C} @ \mathrm{H}](\mathrm{C}) \mathrm{C}[\mathrm{C} @ @](\mathrm{C})(\mathrm{O})[\mathrm{C} @ \mathrm{H}](\mathrm{O}[\mathrm{C} @ @ \mathrm{H}] 5 \mathrm{O}[\mathrm{C} @ \mathrm{H}](\mathrm{C}) \mathrm{C}[\mathrm{C} @ @ \mathrm{H}]([\mathrm{C} @$ $\mathrm{H}] 50) \mathrm{N}(\mathrm{C}) \mathrm{C})[\mathrm{C} @ @ \mathrm{H}](\mathrm{C})[\mathrm{C} @ \mathrm{H}](\mathrm{O}[\mathrm{C} @ \mathrm{H}] 6 \mathrm{C}[\mathrm{C} @ @](\mathrm{C})(\mathrm{OC})[\mathrm{C} @ @ \mathrm{H}](\mathrm{O})[\mathrm{C} @ \mathrm{H}$ ]$(\mathrm{C}) 06)[\mathrm{C} @ @ \mathrm{H}](\mathrm{C}) \mathrm{C}(=\mathrm{O}) \mathrm{N}[\mathrm{C} @ @ \mathrm{H}](\mathrm{C}(\mathrm{C}) \mathrm{C}) \mathrm{C}(=0) \mathrm{N} 4) \mathrm{cc} 3$

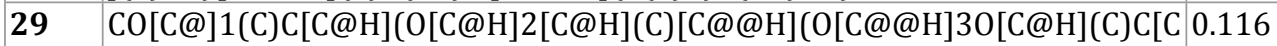
$@ @ \mathrm{H}]([\mathrm{C} @ \mathrm{H}] 30) \mathrm{N}(\mathrm{C}) \mathrm{C})[\mathrm{C} @](\mathrm{C})(\mathrm{O}) \mathrm{C}[\mathrm{C} @ @ \mathrm{H}](\mathrm{C}) \mathrm{CN}(\mathrm{C}) \mathrm{C}(=\mathrm{O}) \mathrm{C}[\mathrm{C} @ @ \mathrm{H}](\mathrm{Cc} 4$ $\operatorname{ccc}(\mathrm{NC}(=0)[\mathrm{C} @ \mathrm{H}](\mathrm{Cc} 5 \mathrm{ccccc} 5 \mathrm{Cl}) \mathrm{NC}(=0) \mathrm{Cc} 6 \mathrm{ccccc} 6 \mathrm{C}) \mathrm{cc} 4) \mathrm{NC}(=0)[\mathrm{C} @ @ \mathrm{H}](\mathrm{NC}$ $(=0)[C @ @] 2 C) C(C) C) O[C @ @ H(C)[C @ @] 10$

30 CO[C@]1(C)C[C@H](O[C@H]2[C@H](C)[C@@ $@ @$ H]([C@H]30)N(C)C)[C@](C)(O)C[C@@H](C)CN(C)C(=0)C[C@@H](Cc4 $\operatorname{ccc}(\mathrm{NC}(=0)[\mathrm{C} @ \mathrm{H}](\mathrm{Cc} 5 \operatorname{ccccc} 5 \mathrm{Cl}) \mathrm{NC}(=0) \mathrm{Cc} 6 \operatorname{cccc}(\mathrm{C}) \mathrm{c} 6) \operatorname{cc} 4) \mathrm{NC}(=0)[\mathrm{C} @ @ \mathrm{H}]($ $\mathrm{NC}(=\mathrm{O})[\mathrm{C} @ @ \mathrm{H}] 2 \mathrm{C}) \mathrm{C}(\mathrm{C}) \mathrm{C}) \mathrm{O}[\mathrm{C} @ @ \mathrm{H}](\mathrm{C})[\mathrm{C} @ @ \mathrm{H}] 10$

$31 \mathrm{CO}[\mathrm{C} @] 1(\mathrm{C}) \mathrm{C}[\mathrm{C} @ \mathrm{H}](\mathrm{O}[\mathrm{C} @ \mathrm{H}] 2[\mathrm{C} @ \mathrm{H}](\mathrm{C})[\mathrm{C} @ @ \mathrm{H}](\mathrm{O}[\mathrm{C} @ @ \mathrm{H}] 30[\mathrm{C} @ \mathrm{H}](\mathrm{C}) \mathrm{C}[\mathrm{C} 0.243$ @@H]([C@H]30)N(C)C)[C@](C)(O)C[C@@ $](\mathrm{C}) \mathrm{CN}(\mathrm{C}) \mathrm{C}(=\mathrm{C}) \mathrm{C}[\mathrm{C} @ \mathrm{H}](\mathrm{Cc} 4$ $\operatorname{ccc}(\mathrm{NC}(=0)[\mathrm{C} @ \mathrm{H}](\mathrm{Cc} 5 \operatorname{ccccc} 5 \mathrm{Cl}) \mathrm{NC}(=0) \mathrm{Cc} 6 \operatorname{ccc}(\mathrm{C}) \operatorname{cc} 6) \operatorname{cc} 4) \mathrm{NC}(=0)[\mathrm{C} @ @ \mathrm{H}]($ $\mathrm{NC}(=0)[\mathrm{C} @ @ \mathrm{H}] 2 \mathrm{C}) \mathrm{C}(\mathrm{C}) \mathrm{C}) \mathrm{O}[\mathrm{C} @ @ \mathrm{H}](\mathrm{C})[\mathrm{C} @ @ \mathrm{H}] 10$

32 CO[C@]1(C)C[C@H](O[C@H]2[C@H](C)[C@@ $[\mathrm{H}](\mathrm{O}[\mathrm{C} @ @ H] 30[\mathrm{C} @ H](\mathrm{C}) \mathrm{C}[\mathrm{C} 0.198$ $@ @ \mathrm{H}]([\mathrm{C} @ \mathrm{H}] 30) \mathrm{N}(\mathrm{C}) \mathrm{C})[\mathrm{C} @](\mathrm{C})(\mathrm{O}) \mathrm{C}[\mathrm{C} @ @ \mathrm{H}](\mathrm{C}) \mathrm{CN}(\mathrm{C}) \mathrm{C}(=\mathrm{O}) \mathrm{C}[\mathrm{C} @ @ \mathrm{H}](\mathrm{Cc} 4$ $\operatorname{ccc}(\mathrm{NC}(=0)[\mathrm{C} @ \mathrm{H}](\mathrm{Cc} 5 \operatorname{ccccc} 5 \mathrm{Cl}) \mathrm{NC}(=0) \mathrm{Cc} 6 \operatorname{ccccc} 6 \mathrm{~F}) \mathrm{cc} 4) \mathrm{NC}(=0)[\mathrm{C} @ @ \mathrm{H}](\mathrm{NC}$ (=0)[C@@H]2C)C(C)C)O[C@@H](C)[C@@H]10

33 CO[C@]1(C)C[C@H](O[C@H]2[C@H](C)[C@@] $(\mathrm{O}[\mathrm{C} @ @ H] 30[\mathrm{C} @ H](\mathrm{C}) \mathrm{C}[\mathrm{C} 0.08$ $@ @ H]([\mathrm{C} @ H] 30) N(\mathrm{C}) \mathrm{C})[\mathrm{C} @](\mathrm{C})(\mathrm{O}) \mathrm{C}[\mathrm{C} @ @ \mathrm{H}](\mathrm{C}) \mathrm{CN}(\mathrm{C}) \mathrm{C}(=\mathrm{O}) \mathrm{C}[\mathrm{C} @ \mathrm{H}](\mathrm{Cc} 4$ $\operatorname{ccc}(\mathrm{NC}(=0)[\mathrm{C} @ \mathrm{H}](\mathrm{Cc} 5 \mathrm{ccccc} 5 \mathrm{Cl}) \mathrm{NC}(=0) \mathrm{Cc} 6 \mathrm{cccc}(\mathrm{F}) \mathrm{c} 6) \mathrm{cc} 4) \mathrm{NC}(=0)[\mathrm{C} @ @ \mathrm{H}]($ $\mathrm{NC}(=0)[\mathrm{C} @ @ \mathrm{H}] 2 \mathrm{C}) \mathrm{C}(\mathrm{C}) \mathrm{C}) \mathrm{O}[\mathrm{C} @ @ \mathrm{H}](\mathrm{C})[\mathrm{C} @ @ \mathrm{H}] 10$

$34 \mathrm{CO}[\mathrm{C} @] 1(\mathrm{C}) \mathrm{C}[\mathrm{C} @ \mathrm{H}](\mathrm{O}[\mathrm{C} @ \mathrm{H}] 2[\mathrm{C} @ \mathrm{H}](\mathrm{C})[\mathrm{C} @ @ \mathrm{H}](\mathrm{O}[\mathrm{C} @ @ \mathrm{H}] 3 \mathrm{O}[\mathrm{C} @ \mathrm{H}](\mathrm{C}) \mathrm{C}[\mathrm{C} 0.573$ @@H]([C@H]3O)N(C)C)[C@](C)(O)C[C@@H](C)CN(C)C(=O)C[C@@H](Cc4 
Cpd \# SMILES

$\operatorname{ccc}(\mathrm{NC}(=0)[\mathrm{C} @ \mathrm{H}](\mathrm{Cc} 5 \mathrm{ccccc} 5 \mathrm{Cl}) \mathrm{NC}(=0) \mathrm{Cc} 6 \mathrm{ccc}(\mathrm{F}) \mathrm{cc} 6) \operatorname{cc} 4) \mathrm{NC}(=0)[\mathrm{C} @ @ \mathrm{H}]($ $\mathrm{NC}(=0)[\mathrm{C} @ @ \mathrm{H}] 2 \mathrm{C}) \mathrm{C}(\mathrm{C}) \mathrm{C}) \mathrm{O}[\mathrm{C} @ @ \mathrm{H}](\mathrm{C})[\mathrm{C} @ @ \mathrm{H}] 10$

$35 \quad \mathrm{CO}[\mathrm{C} @] 1(\mathrm{C}) \mathrm{C}[\mathrm{C} @ \mathrm{H}](\mathrm{O}[\mathrm{C} @ \mathrm{H}] 2[\mathrm{C} @ \mathrm{H}](\mathrm{C})[\mathrm{C} @ @ \mathrm{H}](\mathrm{O}[\mathrm{C} @ @ \mathrm{H}] 3 \mathrm{O}[\mathrm{C} @ \mathrm{H}](\mathrm{C}) \mathrm{C}[\mathrm{C} 0.471$ @@H]([C@H]3O)N(C)C)[C@](C)(O)C[C@@H](C)CN(C)C(=O)C[C@@H](Cc4 $\operatorname{ccc}(\mathrm{NC}(=0)[\mathrm{C} @ \mathrm{H}](\mathrm{Cc} 5 \operatorname{ccccc} 5 \mathrm{Cl}) \mathrm{NC}(=0) \mathrm{Cc} 6 \operatorname{cccc}(\mathrm{c} 6) \mathrm{C} \# \mathrm{~N}) \mathrm{cc} 4) \mathrm{NC}(=0)[\mathrm{C} @ @$ $\mathrm{H}](\mathrm{NC}(=\mathrm{O})[\mathrm{C} @ @ \mathrm{H}] 2 \mathrm{C}) \mathrm{C}(\mathrm{C}) \mathrm{C}) \mathrm{O}[\mathrm{C} @ \mathrm{H}](\mathrm{C})[\mathrm{C} @ @ \mathrm{H}] 1 \mathrm{O}$

36 CO[C@]1(C)C[C@H](O[C@H]2[C@H](C)[C@@H](O[C@@ @@H]([C@H]30)N(C)C)[C@](C)(O)C[C@@H](C)CN(C)C(=0)C[C@@H](Cc4 $\operatorname{ccc}(\mathrm{NC}(=0)[\mathrm{C} @ \mathrm{H}](\mathrm{Cc} 5 \operatorname{ccccc} 5 \mathrm{Cl}) \mathrm{NC}(=0) \mathrm{Cc} 6 \operatorname{ccc}(\mathrm{cc} 6) \mathrm{C} \# \mathrm{~N}) \operatorname{cc} 4) \mathrm{NC}(=0)[\mathrm{C} @ @$ $\mathrm{H}](\mathrm{NC}(=0)[\mathrm{C} @ @ \mathrm{H}] 2 \mathrm{C}) \mathrm{C}(\mathrm{C}) \mathrm{C}) \mathrm{O}[\mathrm{C} @ @ \mathrm{H}](\mathrm{C})[\mathrm{C} @ @ \mathrm{H}] 10$

37 CO[C@]1(C)C[C@H](O[C@H]2[C@H](C)[C@@H](O[C@@]3O[C@H](C)C[C 1.602 $@ @ \mathrm{H}]([\mathrm{C} @ \mathrm{H}] 30) \mathrm{N}(\mathrm{C}) \mathrm{C})[\mathrm{C} @](\mathrm{C})(\mathrm{O}) \mathrm{C}[\mathrm{C} @ @ \mathrm{H}](\mathrm{C}) \mathrm{CN}(\mathrm{C}) \mathrm{C}(=\mathrm{O}) \mathrm{C}[\mathrm{C} @ @ \mathrm{H}](\mathrm{Cc} 4$ $\operatorname{ccc}(\mathrm{NC}(=0)[\mathrm{C} @ \mathrm{H}](\mathrm{Cc} 5 \operatorname{ccccc} 5 \mathrm{Cl}) \mathrm{NC}(=0) \mathrm{Cc} 6 \operatorname{ccc}(\operatorname{cc} 6) \mathrm{S}(=0)(=0) \mathrm{C}) \operatorname{cc} 4) \mathrm{NC}(=0)$ [C@@ $@$ ] $\mathrm{NC}(=0)[\mathrm{C} @ @ \mathrm{H}] 2 \mathrm{C}) \mathrm{C}(\mathrm{C}) \mathrm{C}) \mathrm{O}[\mathrm{C} @ @ \mathrm{H}](\mathrm{C})[\mathrm{C} @ @ \mathrm{H}] 10$

38 CO[C@]1(C)C[C@H](O[C@H]2[C@H](C)[C@@H](O[C@@ $@ 30[\mathrm{C} @ H](C) C[C 0.946$ @@H]([C@H]3O)N(C)C)[C@](C)(O)C[C@@H](C)CN(C)C(=O)C[C@@H](Cc4 $\operatorname{ccc}(\mathrm{NC}(=0)[\mathrm{C} @ \mathrm{H}](\mathrm{Cc} 5 \operatorname{ccccc} 5 \mathrm{Cl}) \mathrm{NC}(=0) \mathrm{C} \operatorname{cocccc}(\mathrm{c} 6) \mathrm{S}(=0)(=0) \mathrm{C}) \operatorname{cc} 4) \mathrm{NC}(=0)$ [C@@H](NC(=) [C@@ @H]2C)C(C)C)O[C@@H](C)[C@@]10

39 CO[C@]1(C)C[C@H](O[C@H]2[C@H](C)[C@@H](O[C@@H]3O[C@H](C)C[C >10 @@H]([C@H]30)N(C)C)[C@](C)(O)C[C@@H](C)CN(C)C(=O)C[C@ @H](Cc4 $\operatorname{ccc}(\mathrm{NC}(=0)[\mathrm{C} @ \mathrm{H}](\mathrm{Cc} 5 \operatorname{ccccc} 5 \mathrm{Cl}) \mathrm{NC}(=0) \mathrm{Cc} 6 \operatorname{ccc}(\operatorname{cc} 6) \mathrm{C}(=0) 0) \operatorname{cc} 4) \mathrm{NC}(=0)[\mathrm{C} @$ @H](NC(=) [C@@H]2C)C(C)C)O[C@@H](C)[C@@H]10

40 CO[C@]1(C)C[C@H](O[C@H]2[C@H](C)[C@@ @H](O[C@@H]3O[C@H](C)C[C 0.2080 .1080 .167 $@ @ \mathrm{H}]([\mathrm{C} @ \mathrm{H}] 30) \mathrm{N}(\mathrm{C}) \mathrm{C})[\mathrm{C} @](\mathrm{C})(\mathrm{O}) \mathrm{C}[\mathrm{C} @ @ \mathrm{H}](\mathrm{C}) \mathrm{CN}(\mathrm{C}) \mathrm{C}(=\mathrm{O}) \mathrm{C}[\mathrm{C} @ @ \mathrm{H}](\mathrm{Cc} 4$ $\operatorname{ccc}(\mathrm{NC}(=))[\mathrm{C} @ \mathrm{H}](\mathrm{Cc} 5 \mathrm{ccccc} 5 \mathrm{Cl}) \mathrm{NC}(=0) \mathrm{C}(\mathrm{F})(\mathrm{F}) \mathrm{c} 6 \mathrm{ccccc} 6) \operatorname{cc} 4) \mathrm{NC}(=0)[\mathrm{C} @ @$ $\mathrm{H}](\mathrm{NC}(=0)[\mathrm{C} @ @ H] 2 \mathrm{C}) \mathrm{C}(\mathrm{C}) \mathrm{C}) \mathrm{O}[\mathrm{C} @ @ \mathrm{H}](\mathrm{C})[\mathrm{C} @ @ \mathrm{H}] 10$

41 CO[C@]1(C)C[C@H](O[C@H]2[C@H](C)[C@@H](O[C@@ $@ @$ @ $]([\mathrm{C} @ \mathrm{H}] 30) \mathrm{N}(\mathrm{C}) \mathrm{C})[\mathrm{C} @](\mathrm{C})(\mathrm{O}) \mathrm{C}[\mathrm{C} @ @ \mathrm{H}](\mathrm{C}) \mathrm{CN}(\mathrm{C}) \mathrm{C}(=\mathrm{O}) \mathrm{C}[\mathrm{C} @ @ \mathrm{H}](\mathrm{Cc} 4$ $\operatorname{ccc}(\mathrm{NC}(=))[\mathrm{C} @ \mathrm{H}](\mathrm{Cc} 5 \operatorname{ccccc} 5 \mathrm{Cl}) \mathrm{NC}(=0) \operatorname{c6} 6 \mathrm{cccc} 6) \operatorname{cc} 4) \mathrm{NC}(=0)[\mathrm{C} @ @ \mathrm{H}](\mathrm{NC}(=$ 0)[C@@H]2C)C(C)C)O[C@@H](C)[C@@H]10

$42 \operatorname{COc1} 1 \operatorname{ccc}(\operatorname{cc} 1) \mathrm{C} 2(\mathrm{CC} 2) \mathrm{C}(=0) \mathrm{N}[\mathrm{C} @ @ \mathrm{H}](\mathrm{Cc} 3 \operatorname{ccccc} 3 \mathrm{Cl}) \mathrm{C}(=0) \mathrm{Nc} 4 \operatorname{ccc}(\mathrm{C}[\mathrm{C} @ @ \mathrm{H}] 5.390$ $5 \mathrm{CC}(=\mathrm{O}) \mathrm{N}(\mathrm{C}) \mathrm{C}[\mathrm{C} @ \mathrm{H}](\mathrm{C}) \mathrm{C}[\mathrm{C} @ @](\mathrm{C})(\mathrm{O})[\mathrm{C} @ \mathrm{H}](\mathrm{O}[\mathrm{C} @ \mathrm{H}] 6 \mathrm{O}[\mathrm{C} @ \mathrm{H}](\mathrm{C}) \mathrm{C}[\mathrm{C} @$ @H]([C@H]6O)N(C)C)[C@@H](C)[C@H](O[C@H]7C[C@@](C)(OC)[C@@H ]$(0)[\mathrm{C} @ H](C) O 7)[\mathrm{C} @ @ H](C) C(=0) N[C @ @](C(C) C) C(=0) N 5) c c 4$ 
Cpd \# SMILES

$3 \mathrm{CO}[\mathrm{C} @] 1(\mathrm{C}) \mathrm{C}[\mathrm{C} @ \mathrm{H}](\mathrm{O}[\mathrm{C} @ \mathrm{H}] 2[\mathrm{C} @ \mathrm{H}](\mathrm{C})[\mathrm{C} @ @ \mathrm{H}](\mathrm{O}[\mathrm{C} @ @ \mathrm{H}] 30[\mathrm{C} @ \mathrm{H}](\mathrm{C}) \mathrm{C}[\mathrm{C} 1.187$ $@ @ H]([\mathrm{C} @ H] 30) N(\mathrm{C}) \mathrm{C})[\mathrm{C} @](\mathrm{C})(\mathrm{O}) \mathrm{C}[\mathrm{C} @ @ \mathrm{H}](\mathrm{C}) \mathrm{CN}(\mathrm{C}) \mathrm{C}(=\mathrm{O}) \mathrm{C}[\mathrm{C} @ \mathrm{H}](\mathrm{Cc} 4$ $\operatorname{ccc}(\mathrm{NC}(=0)[\mathrm{C} @ \mathrm{H}](\mathrm{Cc} 5 \operatorname{ccccc} 5 \mathrm{Cl}) \mathrm{NC}(=0) \mathrm{C}(0) \operatorname{cocccc} 6) \operatorname{cc} 4) \mathrm{NC}(=0)[\mathrm{C} @ @ \mathrm{H}]($ $\mathrm{NC}(=0)[\mathrm{C} @ @ \mathrm{H}] 2 \mathrm{C}) \mathrm{C}(\mathrm{C}) \mathrm{C}) \mathrm{O}[\mathrm{C} @ @ \mathrm{H}](\mathrm{C})[\mathrm{C} @ @ \mathrm{H}] 10$

$44 \mathrm{CO}[\mathrm{C} @] 1(\mathrm{C}) \mathrm{C}[\mathrm{C} @ \mathrm{H}](\mathrm{O}[\mathrm{C} @ \mathrm{H}] 2[\mathrm{C} @ \mathrm{H}](\mathrm{C})[\mathrm{C} @ @ \mathrm{H}](\mathrm{O}[\mathrm{C} @ @ \mathrm{H}] 3 \mathrm{O}[\mathrm{C} @ \mathrm{H}](\mathrm{C}) \mathrm{C}[\mathrm{C} 0.246$ @@H]([C@H]30)N(C)C)[C@](C)(O)C[C@@H](C)CN(C)C(=O)C[C@@ $\operatorname{ccc}(\mathrm{NC}(=0)[\mathrm{C} @ \mathrm{H}](\mathrm{Cc} 5 \operatorname{ccccc} 5 \mathrm{Cl}) \mathrm{NC}(=0) \mathrm{C}(\mathrm{C}) \operatorname{c6} \operatorname{ccccc} 6) \operatorname{cc} 4) \mathrm{NC}(=0)[\mathrm{C} @ @ \mathrm{H}]($ $\mathrm{NC}(=0)[\mathrm{C} @ @ \mathrm{H}] 2 \mathrm{C}) \mathrm{C}(\mathrm{C}) \mathrm{C}) \mathrm{O}[\mathrm{C} @ @ \mathrm{H}](\mathrm{C})[\mathrm{C} @ @ \mathrm{H}] 10$

$45 \quad \mathrm{CO}[\mathrm{C} @] 1(\mathrm{C}) \mathrm{C}[\mathrm{C} @ \mathrm{H}](\mathrm{O}[\mathrm{C} @ \mathrm{H}] 2[\mathrm{C} @ \mathrm{H}](\mathrm{C})[\mathrm{C} @ @ \mathrm{H}](\mathrm{O}[\mathrm{C} @ @ \mathrm{H}] 3 \mathrm{O}[\mathrm{C} @ \mathrm{H}](\mathrm{C}) \mathrm{C}[\mathrm{C} 1.091$ $@ @ \mathrm{H}]([\mathrm{C} @ \mathrm{H}] 30) \mathrm{N}(\mathrm{C}) \mathrm{C})[\mathrm{C} @](\mathrm{C})(\mathrm{O}) \mathrm{C}[\mathrm{C} @ @ \mathrm{H}](\mathrm{C}) \mathrm{CN}(\mathrm{C}) \mathrm{C}(=\mathrm{O}) \mathrm{C}[\mathrm{C} @ \mathrm{H}](\mathrm{Cc} 4$ $\operatorname{ccc}(\mathrm{NC}(=0)[\mathrm{C} @ \mathrm{H}](\mathrm{Cc} 5 \operatorname{ccccc} 5 \mathrm{Cl}) \mathrm{NC}(=0) \mathrm{COc} 6 \operatorname{ccccc} 6) \operatorname{cc} 4) \mathrm{NC}(=0)[\mathrm{C} @ @ \mathrm{H}](\mathrm{N}$ $\mathrm{C}(=\mathrm{O})[\mathrm{C} @ @ \mathrm{H}] 2 \mathrm{C}) \mathrm{C}(\mathrm{C}) \mathrm{C}) \mathrm{O}[\mathrm{C} @ @ \mathrm{H}](\mathrm{C})[\mathrm{C} @ @ \mathrm{H}] 10$

$46 \mathrm{CO}[\mathrm{C} @] 1(\mathrm{C}) \mathrm{C}[\mathrm{C} @ \mathrm{H}](\mathrm{O}[\mathrm{C} @ \mathrm{H}] 2[\mathrm{C} @ \mathrm{H}](\mathrm{C})[\mathrm{C} @ @ \mathrm{H}](\mathrm{O}[\mathrm{C} @ @ \mathrm{H}] 30[\mathrm{C} @ \mathrm{H}](\mathrm{C}) \mathrm{C}[\mathrm{C} 0.059$ @@H]([C@H]3O)N(C)C)[C@](C)(O)C[C@@H](C)CN(C)C(=O)C[C@@H](Cc4 $\operatorname{ccc}(\mathrm{NC}(=0)[\mathrm{C} @ \mathrm{H}](\mathrm{Cc} 5 \mathrm{ccccc} 5 \mathrm{Cl}) \mathrm{NC}(=0) 0 \mathrm{Cc} 6 \operatorname{ccccc} 6) \mathrm{cc} 4) \mathrm{NC}(=0)[\mathrm{C} @ @ \mathrm{H}](\mathrm{N}$ $\mathrm{C}(=0)[\mathrm{C} @ @ \mathrm{H}] 2 \mathrm{C}) \mathrm{C}(\mathrm{C}) \mathrm{C}) \mathrm{O}[\mathrm{C} @ @ \mathrm{H}](\mathrm{C})[\mathrm{C} @ @ \mathrm{H}] 10$

47 CO[C@]1(C)C[C@H](O[C@H]2[C@H](C)[C@@] $0[\mathrm{O}[\mathrm{C} @ @ H] 30[\mathrm{C} @ H](\mathrm{C}) \mathrm{C}[\mathrm{C} 2.563$ $@ @ \mathrm{H}]([\mathrm{C} @ \mathrm{H}] 30) \mathrm{N}(\mathrm{C}) \mathrm{C})[\mathrm{C} @](\mathrm{C})(\mathrm{O}) \mathrm{C}[\mathrm{C} @ @ \mathrm{H}](\mathrm{C}) \mathrm{CN}(\mathrm{C}) \mathrm{C}(=\mathrm{O}) \mathrm{C}[\mathrm{C} @ \mathrm{H}](\mathrm{Cc} 4$ $\operatorname{ccc}(\mathrm{NC}(=0)[\mathrm{C} @ \mathrm{H}](\mathrm{Cc} 5 \mathrm{ccccc} 5 \mathrm{Cl}) \mathrm{NS}(=0)(=0) \mathrm{Cc} 6 \mathrm{ccccc} 6) \mathrm{cc} 4) \mathrm{NC}(=0)[\mathrm{C} @ @ \mathrm{H}]$ $(\mathrm{NC}=0)[\mathrm{C} @ @ \mathrm{H}] 2 \mathrm{C}) \mathrm{C}(\mathrm{C}) \mathrm{C}) \mathrm{O}[\mathrm{C} @ @ \mathrm{H}](\mathrm{C})[\mathrm{C} @ @ \mathrm{H}] 10$

48 CO[C@]1(C)C[C@H] $\mathrm{O}[\mathrm{C} @ \mathrm{H}] 2[\mathrm{C} @ \mathrm{H}](\mathrm{C})[\mathrm{C} @ @ \mathrm{H}](\mathrm{O}[\mathrm{C} @ @ \mathrm{H}] 3 \mathrm{O}[\mathrm{C} @ \mathrm{H}](\mathrm{C}) \mathrm{C}[\mathrm{C} 0.040$ @@H]([C@H]30)N(C)C)[C@](C)(O)C[C@@H](C)CN(C)C(=O)C[C@@H]CC4 ccc $(\mathrm{NC}(=0)[\mathrm{C} @ \mathrm{H}](\mathrm{Cc} 5 \mathrm{ccccc} 5 \mathrm{Cl}) \mathrm{NC}(=0) \mathrm{Nc} 6 \mathrm{ccccc} 6) \mathrm{cc} 4) \mathrm{NC}(=0)[\mathrm{C} @ @ \mathrm{H}](\mathrm{NC}($ $=0)[\mathrm{C} @ @ H] 2 \mathrm{C}) \mathrm{C}(\mathrm{C}) \mathrm{C}) \mathrm{O}[\mathrm{C} @ \mathrm{H}](\mathrm{C})[\mathrm{C} @ @ \mathrm{H}] 10$

$49 \mathrm{CO}[\mathrm{C} @] 1(\mathrm{C}) \mathrm{C}[\mathrm{C} @ \mathrm{H}](\mathrm{O}[\mathrm{C} @ \mathrm{H}] 2[\mathrm{C} @ \mathrm{H}](\mathrm{C})[\mathrm{C} @ @ \mathrm{H}](\mathrm{O}[\mathrm{C} @ @ \mathrm{H}] 3 \mathrm{O}[\mathrm{C} @ \mathrm{H}](\mathrm{C}) \mathrm{C}[\mathrm{C} 0.0390 .1440 .40430-$ $@ @ H]([\mathrm{C} @ \mathrm{H}] 30) \mathrm{N}(\mathrm{C}) \mathrm{C})[\mathrm{C} @](\mathrm{C})(\mathrm{O}) \mathrm{C}[\mathrm{C} @ @ \mathrm{H}](\mathrm{C}) \mathrm{CN}(\mathrm{C}) \mathrm{C}(=\mathrm{O}) \mathrm{C}[\mathrm{C} @ \mathrm{H}](\mathrm{Cc} 4$ $\operatorname{ccc}(\mathrm{NC}(=0)[\mathrm{C} @ \mathrm{H}](\mathrm{Cc} 5 \operatorname{ccccc} 5 \mathrm{Cl}) \mathrm{NC}(=0) \mathrm{NCc} 6 \mathrm{ccccc} 6) \operatorname{cc} 4) \mathrm{NC}(=0)[\mathrm{C} @ @ \mathrm{H}](\mathrm{N}$ $\mathrm{C}(=0)[\mathrm{C} @ @ \mathrm{H}] 2 \mathrm{C}) \mathrm{C}(\mathrm{C}) \mathrm{C}) \mathrm{O}[\mathrm{C} @ @ \mathrm{H}](\mathrm{C})[\mathrm{C} @ @ \mathrm{H}] 10$

$50 \quad \mathrm{CO}[\mathrm{C} @] 1(\mathrm{C}) \mathrm{C}[\mathrm{C} @ \mathrm{H}](\mathrm{O}[\mathrm{C} @ \mathrm{H}] 2[\mathrm{C} @ \mathrm{H}](\mathrm{C})[\mathrm{C} @ @ \mathrm{H}](\mathrm{O}[\mathrm{C} @ @ \mathrm{H}] 30[\mathrm{C} @ \mathrm{H}](\mathrm{C}) \mathrm{C}[\mathrm{C} 0.03$ $@ @ \mathrm{H}]([\mathrm{C} @ \mathrm{H}] 30) \mathrm{N}(\mathrm{C}) \mathrm{C})[\mathrm{C} @](\mathrm{C})(\mathrm{O}) \mathrm{C}[\mathrm{C} @ @ \mathrm{H}](\mathrm{C}) \mathrm{CN}(\mathrm{C}) \mathrm{C}(=\mathrm{O}) \mathrm{C}[\mathrm{C} @ \mathrm{H}](\mathrm{Cc} 4$ $\operatorname{ccc}(\mathrm{NC}(=0)[\mathrm{C} @ \mathrm{H}](\mathrm{Cc} 5 \mathrm{ccccc} 5 \mathrm{Cl}) \mathrm{NC}(=0) \mathrm{Nc} 6 \mathrm{ccccc} 6 \mathrm{~F}) \mathrm{cc} 4) \mathrm{NC}(=0)[\mathrm{C} @ @ \mathrm{H}](\mathrm{N}$ $\mathrm{C}(=0)[\mathrm{C} @ \mathrm{H}] 2 \mathrm{C}) \mathrm{C}(\mathrm{C}) \mathrm{C}) \mathrm{O}[\mathrm{C} @ @ \mathrm{H}](\mathrm{C})[\mathrm{C} @ @ \mathrm{H}] 10$

51 CO[C@]1(C)C[C@H](O[C@H]2[C@H](C)[C@@] @@H]([C@H]30)N(C)C)[C@](C)(O)C[C@@H](C)CN(C)C(=O)C[C@@] Cc4 
Cpd \# SMILES

$\operatorname{ccc}(\mathrm{NC}(=0)[\mathrm{C} @ \mathrm{H}](\mathrm{Cc} 5 \operatorname{ccccc} 5 \mathrm{Cl}) \mathrm{NC}(=0) \mathrm{Nc} 6 \operatorname{cccc}(\mathrm{F}) \mathrm{c} 6) \operatorname{cc} 4) \mathrm{NC}(=0)[\mathrm{C} @ @ \mathrm{H}]($ $\mathrm{NC}(=\mathrm{O})[\mathrm{C} @ \mathrm{H}] 2 \mathrm{C}) \mathrm{C}(\mathrm{C}) \mathrm{C}) \mathrm{O}[\mathrm{C} @ @ \mathrm{H}](\mathrm{C})[\mathrm{C} @ @ \mathrm{H}] 10$

$52 \quad \mathrm{CO}[\mathrm{C} @] 1(\mathrm{C}) \mathrm{C}[\mathrm{C} @ \mathrm{H}](\mathrm{O}[\mathrm{C} @ \mathrm{H}] 2[\mathrm{C} @ \mathrm{H}](\mathrm{C})[\mathrm{C} @ @ \mathrm{H}](\mathrm{O}[\mathrm{C} @ @ \mathrm{H}] 3 \mathrm{O}[\mathrm{C} @ \mathrm{H}](\mathrm{C}) \mathrm{C}[\mathrm{C} 0.323$ @@H]([C@H]3O)N(C)C)[C@](C)(O)C[C@@H](C)CN(C)C(=O)C[C@@H](Cc4 $\operatorname{ccc}(\mathrm{NC}(=))[\mathrm{C} @ \mathrm{H}](\mathrm{Cc} 5 \operatorname{ccccc} 5 \mathrm{Cl}) \mathrm{NC}(=0) \mathrm{Nc} 6 \mathrm{ccc}(\mathrm{F}) \mathrm{cc} 6) \mathrm{cc} 4) \mathrm{NC}(=0)[\mathrm{C} @ @ \mathrm{H}] \mathrm{C}$ $\mathrm{NC}=0)[\mathrm{C} @ \mathrm{H}] 2 \mathrm{C}) \mathrm{C}(\mathrm{C}) \mathrm{C}) \mathrm{O}[\mathrm{C} @ @ \mathrm{H}](\mathrm{C})[\mathrm{C} @ @ \mathrm{H}] 10$

53 CO[C@]1(C)C[C@H](O[C@H]2[C@H](C)[C@@H](O[C@@ @@H]([C@H]30)N(C)C)[C@](C)(O)C[C@@H](C)CN(C)C(=O)C[C@@H](Cc4 $\operatorname{ccc}(\mathrm{NC}(=0)[\mathrm{C} @ \mathrm{H}](\mathrm{Cc} 5 \operatorname{ccccc} 5 \mathrm{Cl}) \mathrm{NC}(=0) \mathrm{NC} \operatorname{coccccc} 6 \mathrm{~F}) \operatorname{cc} 4) \mathrm{NC}(=0)[\mathrm{C} @ @ \mathrm{H}]($ $\mathrm{NC}(=0)[\mathrm{C} @ @ \mathrm{H}] 2 \mathrm{C}) \mathrm{C}(\mathrm{C}) \mathrm{C}) \mathrm{O}[\mathrm{C} @ @ \mathrm{H}](\mathrm{C})[\mathrm{C} @ @ \mathrm{H}] 10$

54 CO[C@]1(C)C[C@H](O[C@H]2[C@H](C)[C@@] $(\mathrm{O}[\mathrm{C} @ @ H] 30[\mathrm{C} @ H](\mathrm{C}) \mathrm{C}[\mathrm{C} 0.048$ $@ @ \mathrm{H}]([\mathrm{C} @ \mathrm{H}] 30) \mathrm{N}(\mathrm{C}) \mathrm{C})[\mathrm{C} @](\mathrm{C})(\mathrm{O}) \mathrm{C}[\mathrm{C} @ @ \mathrm{H}](\mathrm{C}) \mathrm{CN}(\mathrm{C}) \mathrm{C}(=\mathrm{O}) \mathrm{C}[\mathrm{C} @ @ \mathrm{H}](\mathrm{Cc} 4$ $\operatorname{ccc}(\mathrm{NC}(=0)[\mathrm{C} @ \mathrm{H}](\mathrm{Cc} 5 \operatorname{ccccc} 5 \mathrm{Cl}) \mathrm{NC}(=0) \mathrm{NCc} 6 \operatorname{cccc}(\mathrm{F}) \mathrm{c} 6) \operatorname{cc} 4) \mathrm{NC}(=0)[\mathrm{C} @ @ \mathrm{H}]$ (NC(=) $[\mathrm{C} @ @ H] 2 \mathrm{C}) \mathrm{C}(\mathrm{C}) \mathrm{C}) \mathrm{O}[\mathrm{C} @ @ \mathrm{H}](\mathrm{C})[\mathrm{C} @ @ \mathrm{H}] 10$

$55 \mathrm{CO}[\mathrm{C} @] 1(\mathrm{C}) \mathrm{C}[\mathrm{C} @ \mathrm{H}](\mathrm{O}[\mathrm{C} @ \mathrm{H}] 2[\mathrm{C} @ \mathrm{H}](\mathrm{C})[\mathrm{C} @ @ \mathrm{H}](\mathrm{O}[\mathrm{C} @ @ \mathrm{H}] 3 \mathrm{O}[\mathrm{C} @ \mathrm{H}](\mathrm{C}) \mathrm{C}[\mathrm{C} 0.179$ @@H]([C@H]3O)N(C)C)[C@](C)(O)C[C@@H](C)CN(C)C(=O)C[C@@H](Cc4 $\operatorname{ccc}(\mathrm{NC}(=0)[\mathrm{C} @ \mathrm{H}](\mathrm{Cc} 5 \operatorname{ccccc} 5 \mathrm{Cl}) \mathrm{NC}(=\mathrm{O}) \mathrm{NCc} 6 \operatorname{ccc}(\mathrm{F}) \mathrm{cc} 6) \operatorname{cc} 4) \mathrm{NC}(=\mathrm{O})[\mathrm{C} @ @ \mathrm{H}]$ $(\mathrm{NC}(=)][\mathrm{C} @ \mathrm{H}] 2 \mathrm{C}) \mathrm{C}(\mathrm{C}) \mathrm{C}) \mathrm{O}[\mathrm{C} @ @ \mathrm{H}](\mathrm{C})[\mathrm{C} @ @ \mathrm{H}] 10$

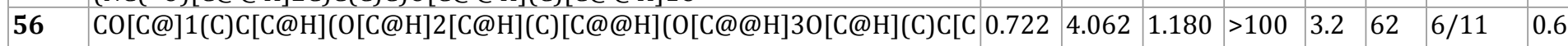
@@H]([C@H]30)N(C)C)[C@](C)(O)C[C@@H](C)CN(C)C(=O)C[C@@H](Cc4 $\operatorname{ccc}(\mathrm{NC}(=0)[\mathrm{C} @ \mathrm{H}](\mathrm{Cc} 5 \operatorname{ccccc} 5 \mathrm{Cl}) \mathrm{NC}(=0) \mathrm{C}) \operatorname{cc} 4) \mathrm{NC}(=0)[\mathrm{C} @ @ \mathrm{H}](\mathrm{NC}(=0)[\mathrm{C} @$ @H]2C)C(C)C)O[C@@H](C)[C@@H]10

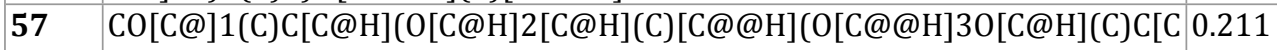
$@ @ \mathrm{H}]([\mathrm{C} @ \mathrm{H}] 30) \mathrm{N}(\mathrm{C}) \mathrm{C})[\mathrm{C} @](\mathrm{C})(\mathrm{O}) \mathrm{C}[\mathrm{C} @ @ \mathrm{H}](\mathrm{C}) \mathrm{CN}(\mathrm{C}) \mathrm{C}(=\mathrm{O}) \mathrm{C}[\mathrm{C} @ @ \mathrm{H}](\mathrm{Cc} 4$ $\operatorname{ccc}(\mathrm{NC}(=))[\mathrm{C} @ \mathrm{H}](\mathrm{Cc} 5 \operatorname{ccc}(\mathrm{Cl}) \operatorname{cc} 5 \mathrm{Cl}) \mathrm{NC}(=0) \mathrm{Cc} 6 \operatorname{ccccc} 6) \operatorname{cc} 4) \mathrm{NC}(=0)[\mathrm{C} @ @ \mathrm{H}] \mathrm{C}$ $\mathrm{NC}(=0)[\mathrm{C} @ @ \mathrm{H}] 2 \mathrm{C}) \mathrm{C}(\mathrm{C}) \mathrm{C}) \mathrm{O}[\mathrm{C} @ @ \mathrm{H}](\mathrm{C})[\mathrm{C} @ @ \mathrm{H}] 10$

$58 \quad \mathrm{CO}[\mathrm{C} @] 1(\mathrm{C}) \mathrm{C}[\mathrm{C} @ \mathrm{H}](\mathrm{O}[\mathrm{C} @ \mathrm{H}] 2[\mathrm{C} @ \mathrm{H}](\mathrm{C})[\mathrm{C} @ @ \mathrm{H}](\mathrm{O}[\mathrm{C} @ @ \mathrm{H}] 3 \mathrm{O}[\mathrm{C} @ \mathrm{H}](\mathrm{C}) \mathrm{C}[\mathrm{C} 0.166$ $@ @ \mathrm{H}]([\mathrm{C} @ \mathrm{H}] 30) \mathrm{N}(\mathrm{C}) \mathrm{C})[\mathrm{C} @](\mathrm{C})(\mathrm{O}) \mathrm{C}[\mathrm{C} @ @ \mathrm{H}](\mathrm{C}) \mathrm{CN}(\mathrm{C}) \mathrm{C}(=\mathrm{O}) \mathrm{C}[\mathrm{C} @ @ \mathrm{H}](\mathrm{Cc} 4$ $\operatorname{ccc}(\mathrm{NC}(=))[\mathrm{C} @ \mathrm{H}](\mathrm{Cc} 5 \mathrm{c}(\mathrm{Cl}) \operatorname{cccc} 5 \mathrm{Cl}) \mathrm{NC}(=0) \mathrm{Cc} 6 \mathrm{ccccc} 6) \operatorname{cc} 4) \mathrm{NC}(=0)[\mathrm{C} @ @ \mathrm{H}]($ $\mathrm{NC}(=0)[\mathrm{C} @ @ \mathrm{H}] 2 \mathrm{C}) \mathrm{C}(\mathrm{C}) \mathrm{C}) \mathrm{O}[\mathrm{C} @ @ \mathrm{H}](\mathrm{C})[\mathrm{C} @ @ \mathrm{H}] 10$

$59 \quad \mathrm{CO}[\mathrm{C} @] 1(\mathrm{C}) \mathrm{C}[\mathrm{C} @ \mathrm{H}](\mathrm{O}[\mathrm{C} @ \mathrm{H}] 2[\mathrm{C} @ \mathrm{H}](\mathrm{C})[\mathrm{C} @ @ \mathrm{H}](\mathrm{O}[\mathrm{C} @ @ \mathrm{H}] 3 \mathrm{O}[\mathrm{C} @ \mathrm{H}](\mathrm{C}) \mathrm{C}[\mathrm{C} 0.315$ @@H]([C@H]3O)N(C)C)[C@](C)(O)C[C@@H](C)CN(C)C(=O)C[C@@ $0 \mathrm{H}](\mathrm{CC} 4$ $\operatorname{ccc}(\mathrm{NC}(=0)[\mathrm{C} @ \mathrm{H}](\mathrm{Cc} 5 \operatorname{ccccc} 5 \mathrm{~F}) \mathrm{NC}(=0) \mathrm{Cc} 6 \mathrm{ccccc} 6) \operatorname{cc} 4) \mathrm{NC}(=0)[\mathrm{C} @ @ \mathrm{H}](\mathrm{NC}($ $=0)[\mathrm{C} @ @ H] 2 \mathrm{C}) \mathrm{C}(\mathrm{C}) \mathrm{C}) \mathrm{O}[\mathrm{C} @ @ \mathrm{H}](\mathrm{C})[\mathrm{C} @ @ \mathrm{H}] 10$ 


\section{Cpd \# SMILES}

$\mathrm{CO}[\mathrm{C} @] 1(\mathrm{C}) \mathrm{C}[\mathrm{C} @ \mathrm{H}](\mathrm{O}[\mathrm{C} @ \mathrm{H}] 2[\mathrm{C} @ \mathrm{H}](\mathrm{C})[\mathrm{C} @ @ \mathrm{H}](\mathrm{O}[\mathrm{C} @ @ \mathrm{H}] 3 \mathrm{O}[\mathrm{C} @ \mathrm{H}](\mathrm{C}) \mathrm{C}[\mathrm{C}$
$@ \mathrm{H}]([\mathrm{C} @ \mathrm{H}] 3 \mathrm{O}) \mathrm{N}(\mathrm{C}) \mathrm{C})[\mathrm{C} @](\mathrm{C})(\mathrm{O}) \mathrm{C}[\mathrm{C} @ \mathrm{H}](\mathrm{C}) \mathrm{CN}(\mathrm{C}) \mathrm{C}(=\mathrm{O}) \mathrm{C}[\mathrm{C} @ \mathrm{H}](\mathrm{Cc} 4$ $\operatorname{ccc}(\mathrm{NC}(=0)[\mathrm{C} @ \mathrm{H}](\mathrm{Cc} 5 \operatorname{ccccc} 5 \mathrm{C}) \mathrm{NC}(=0) \mathrm{Cc} 6 \mathrm{ccccc} 6) \operatorname{cc} 4) \mathrm{NC}(=0)[\mathrm{C} @ @ \mathrm{H}](\mathrm{NC}($ $=0)[\mathrm{C} @ @ H] 2 \mathrm{C}) \mathrm{C}(\mathrm{C}) \mathrm{C}) \mathrm{O}[\mathrm{C} @ \mathrm{H}](\mathrm{C})[\mathrm{C} @ \mathrm{H}] 10$

$61 \quad \mathrm{CO}[\mathrm{C} @] 1(\mathrm{C}) \mathrm{C}[\mathrm{C} @ \mathrm{H}](\mathrm{O}[\mathrm{C} @ \mathrm{H}] 2[\mathrm{C} @ \mathrm{H}](\mathrm{C})[\mathrm{C} @ @ \mathrm{H}](\mathrm{O}[\mathrm{C} @ \mathrm{H}] 30[\mathrm{C} @ \mathrm{H}](\mathrm{C}) \mathrm{C}[\mathrm{C} 2.563$ @@H]([C@H]30)N(C)C)[C@](C)(O)C[C@@ $3(\mathrm{C}) \mathrm{CN}(\mathrm{C}) \mathrm{C}(=\mathrm{C}) \mathrm{C}[\mathrm{C} @ \mathrm{H}](\mathrm{Cc} 4$ $\operatorname{ccc}(\mathrm{NC}(=0)[\mathrm{C} @ \mathrm{H}](\mathrm{Cc} 5 \mathrm{ccccc} 5) \mathrm{NC}(=0) \mathrm{Cc} 6 \mathrm{ccccc} 6) \mathrm{cc} 4) \mathrm{NC}(=0)[\mathrm{C} @ @ \mathrm{H}](\mathrm{NC}=$ 0)[C@@H]2C)C(C)C)O[C@@H](C)[C@@H]10

62 CC(C)[C@@H]1NC(=O)[C@H](C)[C@@](O)[C@H](C)[C@@H](O[C@@H]2 0.910 .2950 .840 O[C@H](C)C[C@@] $[$ [C@H]2O)N(C)C)[C@](C)(O)C[C@@] $(\mathrm{C}) \mathrm{CN}(\mathrm{C}) \mathrm{C}(=\mathrm{O})$ $\mathrm{C}[\mathrm{C} @ @ \mathrm{H}](\mathrm{Cc} 3 \operatorname{ccc}(\mathrm{NC}=0)[\mathrm{C} @ \mathrm{H}](\mathrm{Cc} 4 \mathrm{ccccc} 4 \mathrm{Cl}) \mathrm{NC}(=0) \mathrm{Cc} 5 \mathrm{ccccc} 5) \mathrm{cc} 3) \mathrm{NC} 1=$ 0

$63 \mathrm{CC}(\mathrm{C})[\mathrm{C} @ @ \mathrm{H}] 1 \mathrm{NC}=\mathrm{O})[\mathrm{C} @ \mathrm{H}](\mathrm{C})[\mathrm{C} @ @ \mathrm{H}](\mathrm{O})[\mathrm{C} @ \mathrm{H}](\mathrm{C})[\mathrm{C} @ @ \mathrm{H}](\mathrm{O})[\mathrm{C} @](\mathrm{C})(0.5360 .1251 .330$ $0) \mathrm{C}[\mathrm{C} @ @ \mathrm{H}](\mathrm{C}) \mathrm{CN}(\mathrm{C}) \mathrm{C}(=\mathrm{O}) \mathrm{C}[\mathrm{C} @ @ \mathrm{H}](\mathrm{Cc} 2 \operatorname{ccc}(\mathrm{NC}(=))[\mathrm{C} @ \mathrm{H}](\mathrm{Cc} 3 \operatorname{ccccc} 3 \mathrm{Cl}) \mathrm{N}$ $\mathrm{C}(=0) \mathrm{Cc} 4 \operatorname{ccccc} 4) \mathrm{cc} 2) \mathrm{NC} 1=0$ 
Table S3. Supplementary compounds. (prepared according to: (a) Scheme 2; (b) and (c) Scheme 3; (d) and (e) misc

a)
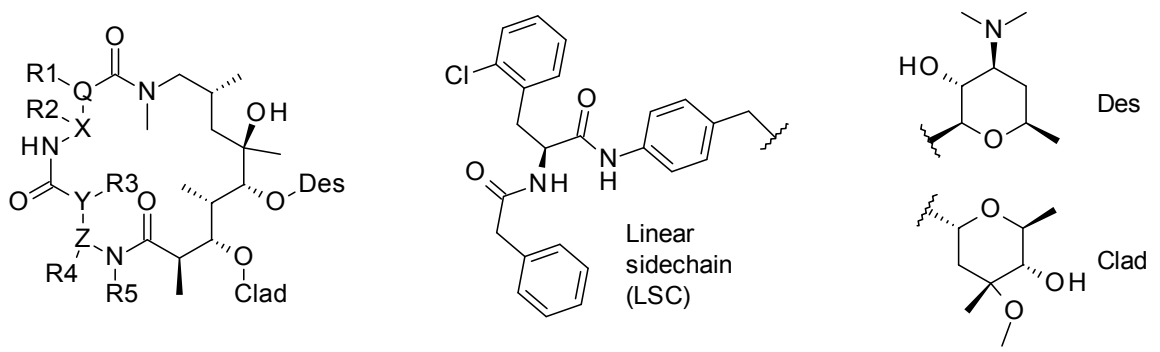

\begin{tabular}{|c|c|c|c|c|c|c|c|c|c|c|}
\hline Cpd \# & $\mathbf{Q}$ & $\mathbf{X}$ & R1 & R2 & R3 & R4 & R5 & $\mathbf{Y}$ & $\mathbf{Z}$ & $\begin{array}{c}\text { ELISA-I } \\
\text { IC }_{50}(\mu \mathrm{M})\end{array}$ \\
\hline S1 & $\mathrm{CH}_{2}$ & $\mathrm{CH}(S)$ & $\mathrm{H}$ & LSC & \multicolumn{2}{|c|}{$-\left(\mathrm{CH}_{2}\right)_{3^{-}}$} & $\mathrm{H}$ & $\mathrm{CH}(R)$ & $\mathrm{CH}(R)$ & $>30$ \\
\hline S2 & $\mathrm{CH}_{2}$ & $\mathrm{CH}(R)$ & $\mathrm{H}$ & LSC & \multicolumn{2}{|c|}{$-\left(\mathrm{CH}_{2}\right)_{3^{-}}$} & $\mathrm{H}$ & $\mathrm{CH}(S)$ & $\mathrm{CH}(S)$ & $>30$ \\
\hline S3 & $\mathrm{CH}_{2}$ & $\mathrm{CH}(R)$ & $\mathrm{H}$ & LSC & \multicolumn{2}{|c|}{$-\left(\mathrm{CH}_{2}\right)_{4^{-}}$} & $\mathrm{H}$ & $\mathrm{CH}(R)$ & $\mathrm{CH}(R)$ & $>30$ \\
\hline S4 & $\mathrm{CH}(R)$ & $\mathrm{CH}(R)$ & \multicolumn{2}{|c|}{$-\left(\mathrm{CH}_{2}\right)_{3}-$} & $\mathrm{H}$ & LSC & $\mathrm{H}$ & $\mathrm{CH}_{2}$ & $\mathrm{CH}(R)$ & $>30$ \\
\hline S5 & $\mathrm{CH}(R)$ & $\mathrm{CH}(R)$ & \multicolumn{2}{|c|}{$-\left(\mathrm{CH}_{2}\right)_{3^{-}}$} & $\mathrm{H}$ & LSC & $\mathrm{H}$ & $\mathrm{CH}_{2}$ & $\mathrm{CH}(S)$ & $>30$ \\
\hline S6 & $\mathrm{CH}(S)$ & $\mathrm{CH}(S)$ & \multicolumn{2}{|c|}{$-\left(\mathrm{CH}_{2}\right)_{3^{-}}$} & $\mathrm{H}$ & LSC & $\mathrm{H}$ & $\mathrm{CH}_{2}$ & $\mathrm{CH}(R)$ & 22.6 \\
\hline S7 & $\mathrm{CH}_{2}$ & $\mathrm{CH}(R)$ & - & LSC & \multicolumn{2}{|c|}{ Cyclopentyl } & $\mathrm{H}$ & $\mathrm{CH}_{2}$ & - & 24.6 \\
\hline S8 & $\mathrm{CH}_{2}$ & $\mathrm{CH}(R)$ & - & LSC & \multicolumn{2}{|c|}{ Cyclohexyl } & $\mathrm{H}$ & $\mathrm{CH}_{2}$ & - & $>30$ \\
\hline s9 & -2 & $\mathrm{CH}(R)$ & - & LSC & - & \multicolumn{2}{|c|}{$-\left(\mathrm{CH}_{2}\right)_{3^{-}}$} & - & $\mathrm{CH}(S)$ & $>30$ \\
\hline S10 & $\mathrm{CH}_{2}$ & $\mathrm{CH}(\mathrm{R})$ & - & LSC & $\mathrm{H}$ & \multicolumn{2}{|c|}{$-\left(\mathrm{CH}_{2}\right)_{3^{-}}$} & $\mathrm{CH}_{2}$ & $\mathrm{CH}(S)$ & $>30$ \\
\hline
\end{tabular}


b)
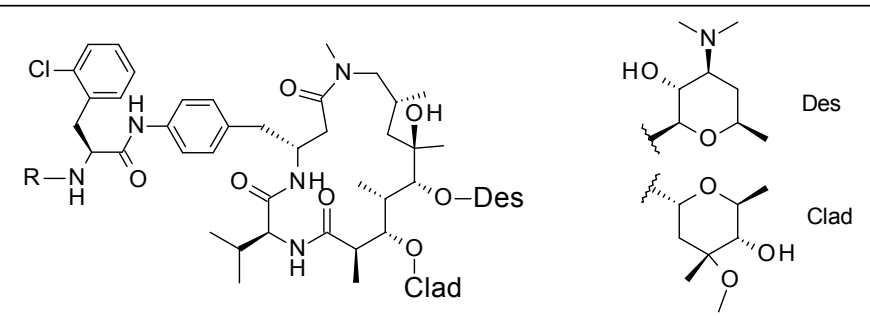

\begin{tabular}{|c|c|c|c|c|c|}
\hline Cpd \# & $\mathbf{R}$ & $\begin{array}{c}\text { ELISA-I } \\
\text { IC }_{50}(\mathrm{nM}) \\
\end{array}$ & Cpd \# & $\mathbf{R}$ & $\begin{array}{c}\text { ELISA-I } \\
\mathrm{IC}_{50}(\mathrm{nM})\end{array}$ \\
\hline S11 & & 400 & $S 21$ & & 225 \\
\hline S12 & & 731 & $S 22$ & & 7297 \\
\hline S13 & & 779 & S23 & & 2077 \\
\hline S14 & & 1143 & $S 24$ & & 1033 \\
\hline S15 & & 763 & $S 25$ & & 1779 \\
\hline S16 & & 4652 & S26 & & 2079 \\
\hline S17 & & 6643 & S27 & & 2700 \\
\hline S18 & & $>30000$ & S28 & & 532 \\
\hline S19 & & 1593 & S29 & & $>10000$ \\
\hline S20 & & 10337 & & & \\
\hline
\end{tabular}




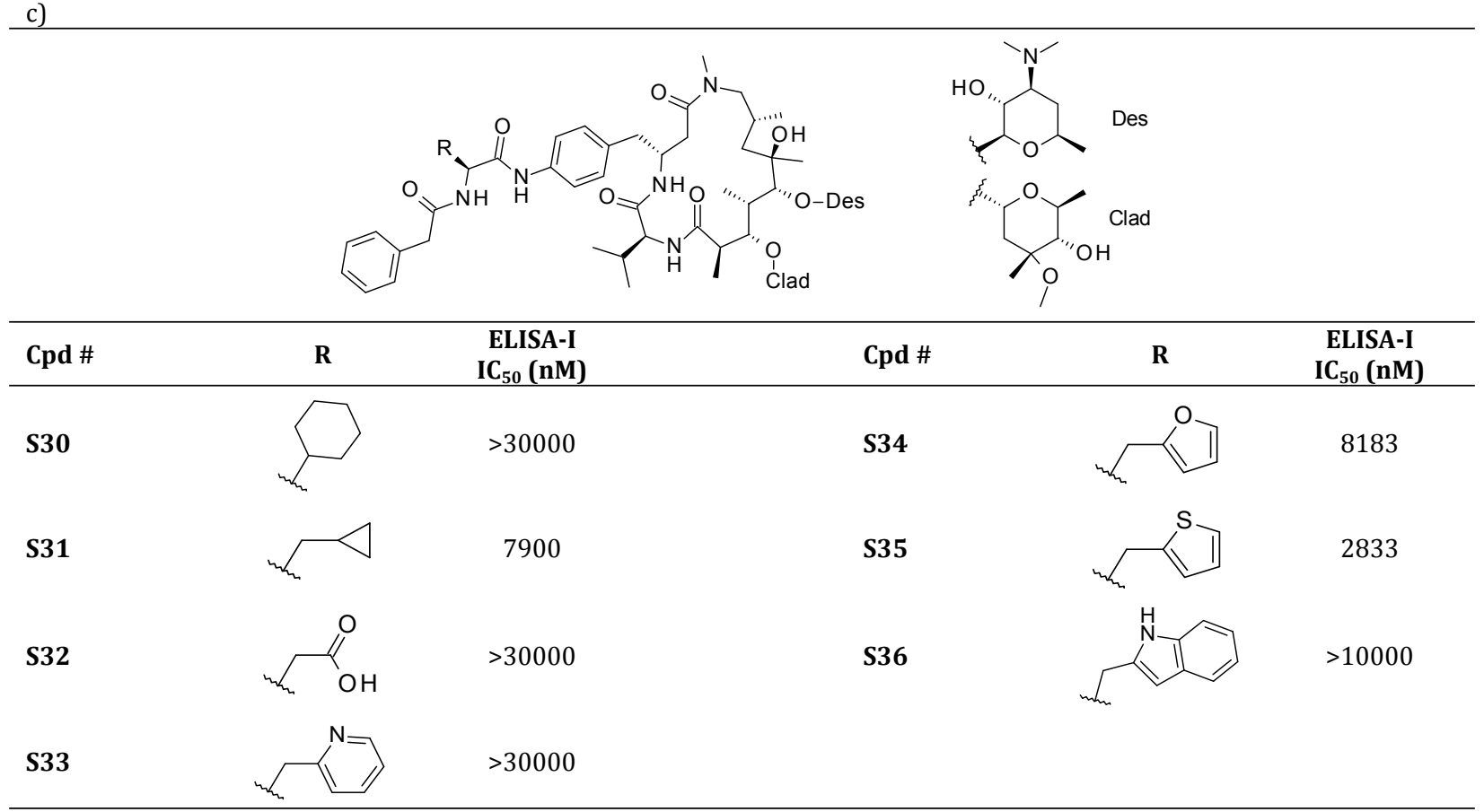

d)

S38




\begin{tabular}{|c|c|c|c|c|c|c|}
\hline Cpd \# & R1 & $\mathbf{X}$ & R2 & $\mathbf{Y}$ & Z & $\begin{array}{c}\text { ELISA-I } \\
\text { IC } \text { Co }_{50}(\mathrm{nM})\end{array}$ \\
\hline S42 & $\mathrm{H}$ & $\mathrm{C}=0$ & $\mathrm{CH}_{3}$ & $\mathrm{C}=0$ & $\mathrm{CH}_{2}$ & $>10000$ \\
\hline S43 & $\mathrm{CH}_{3}$ & $C=0$ & $\mathrm{H}$ & $C=0$ & $\mathrm{CH}_{2}$ & 7789 \\
\hline S44 & $\mathrm{H}$ & $C=0$ & $\mathrm{CH}_{3}$ & $\mathrm{CH}_{2}$ & $\mathrm{CH}_{2}$ & $>30000$ \\
\hline S45 & $\mathrm{H}$ & $C=0$ & $\mathrm{H}$ & $\mathrm{CH}_{2}$ & - & $>30000$ \\
\hline S46 & $\mathrm{H}$ & $C=0$ & $\mathrm{H}$ & $\mathrm{CH}_{2}$ & $\mathrm{CH}_{2}$ & $>30000$ \\
\hline S47 & $\mathrm{H}$ & $\mathrm{CH}_{2}$ & $\mathrm{H}$ & $\mathrm{C}=0$ & $\mathrm{CH}_{2}$ & $>30000$ \\
\hline
\end{tabular}


Table S4. Coupling constants (a), nOe contacts (b), ${ }^{1} \mathrm{H}$ NMR (c) ${ }^{13} \mathrm{C}$ NMR and (d) spectra of compound 4 in $\mathrm{CDCl}_{3}$.

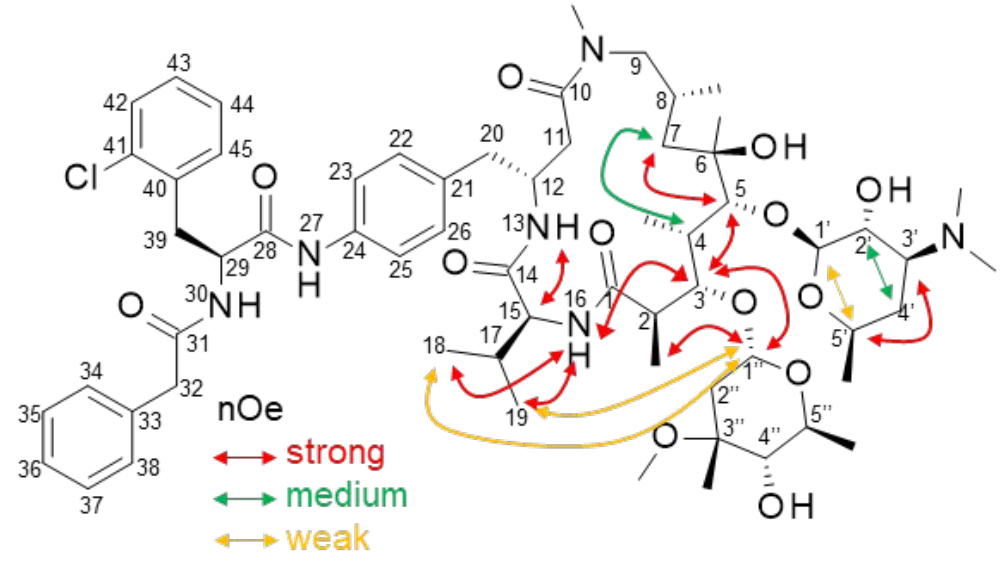

a) Coupling constants of compound 4 in $\mathrm{CDCl}_{3}$

\begin{tabular}{|c|c|c|c|c|c|}
\hline Macrocycle & $3 / \mathrm{Jz}$ & Sugars & ${ }^{3} J / \mathrm{Hz}$ & Substituent & ${ }^{3} \mathrm{~J} / \mathrm{Hz}$ \\
\hline 2,3 & overlap & $1^{\prime}, 2^{\prime}$ & 7.3 & $22(26), 23(25)$ & overlap \\
\hline 3,4 & $<1$ & $2^{\prime}, 3^{\prime}$ & 10.2 & $29,30 \mathrm{NH}$ & 7.8 \\
\hline 4,5 & $<1$ & 3', 4'a & 4.2 & $29,39 a$ & 7.5 \\
\hline $7 \mathrm{a}, 8$ & 13.8 & 3', 4'b & 12.5 & $29,39 \mathrm{~b}$ & 7.5 \\
\hline $7 \mathrm{~b}, 8$ & 5.3 & 4'a, 5' & 1.9 & $34(38), 35(37)$ & overlap \\
\hline $8,9 a$ & 2.9 & $4^{\prime} b, 5^{\prime}$ & 11 & 35 (37), 36 & overlap \\
\hline $8,9 b$ & 11 & 1", 2"a & $<1$ & 42,43 & overlap \\
\hline $11 a, 12$ & overlap & 1", 2"b & 4.6 & 43,44 & overlap \\
\hline 11b, 12 & overlap & 4", 5" & 10 & 44,45 & overlap \\
\hline $12,20 a$ & 6.1 & $5^{\prime}, 5^{\prime} \mathrm{CH}_{3}$ & 6.4 & & \\
\hline $12,20 b$ & overlap & $5^{\prime \prime}, 5^{\prime \prime} \mathrm{CH}_{3}$ & 6.5 & & \\
\hline $13 \mathrm{NH}, 12$ & 7.7 & 2', 2' OH & - & & \\
\hline 15,17 & overlap & 4", 4" OH & - & & \\
\hline $16 \mathrm{NH}, 15$ & unresolved & & & & \\
\hline $17,18(19)$ & 6.8 & & & & \\
\hline $2,2 \mathrm{CH}_{3}$ & 7 & & & & \\
\hline $4,4 \mathrm{CH}_{3}$ & 7.2 & & & & \\
\hline $8,8 \mathrm{CH}_{3}$ & 7 & & & & \\
\hline Macrocycle & ${ }^{2} \mathrm{~J} / \mathrm{Hz}$ & Sugars & ${ }^{2} \mathrm{~J} / \mathrm{Hz}$ & Substituent & ${ }^{2} \mathrm{~J} / \mathrm{Hz}$ \\
\hline $7 a, 7 b$ & 13.8 & $4^{\prime} \mathrm{a}, 4^{\prime} \mathrm{b}$ & 12.0 & $20 \mathrm{a}, 20 \mathrm{~b}$ & 13.4 \\
\hline $9 a, 9 b$ & 13.6 & 2"a, 2"b & 15.4 & $32 \mathrm{a}, 32 \mathrm{~b}$ & overlap \\
\hline $11 a, 11 b$ & - & & & $39 a, 39 b$ & overlap \\
\hline
\end{tabular}




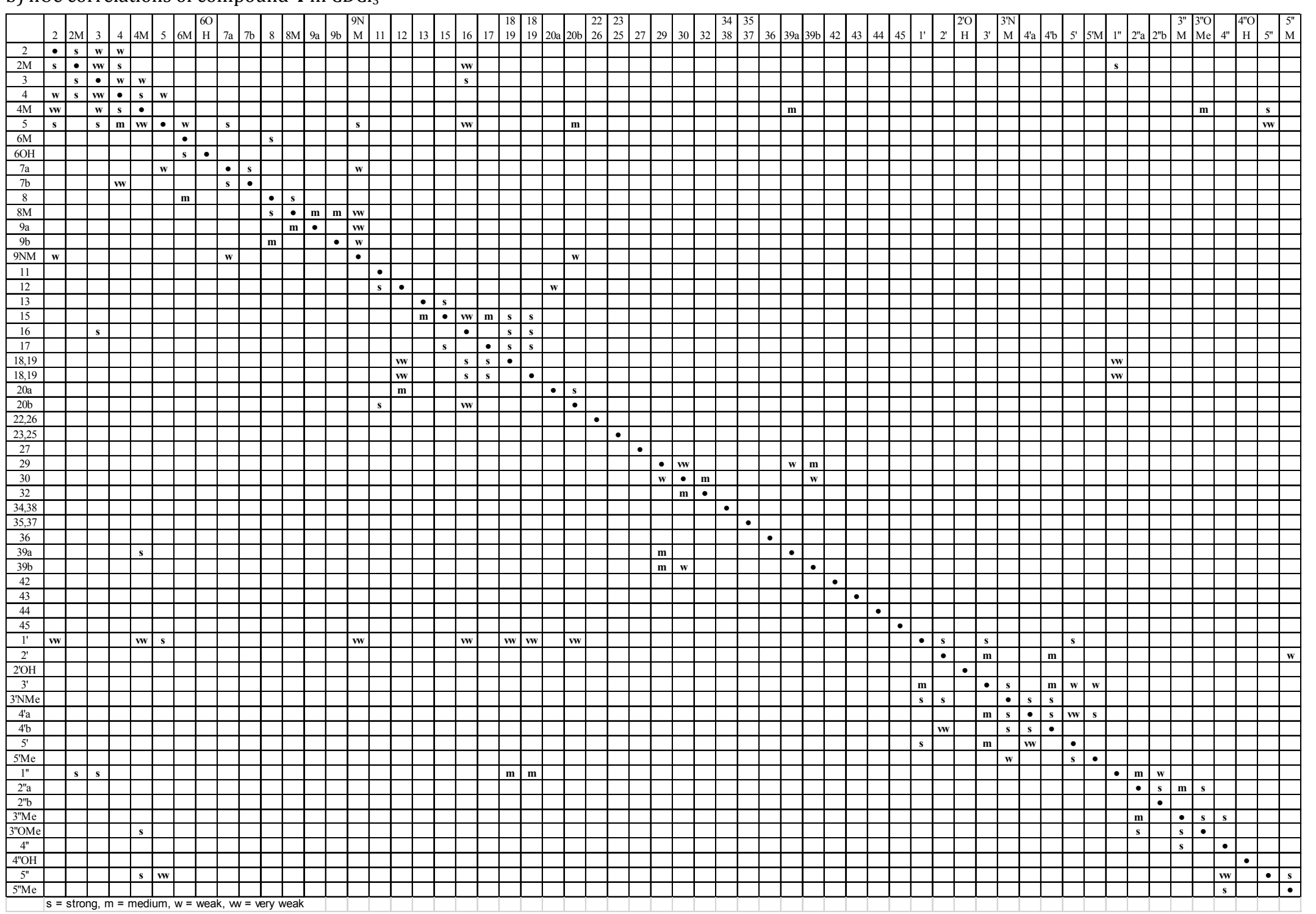


c) ${ }^{1} \mathrm{H}$ NMR spectrum of compound 4 in $\mathrm{CDCl}_{3}$

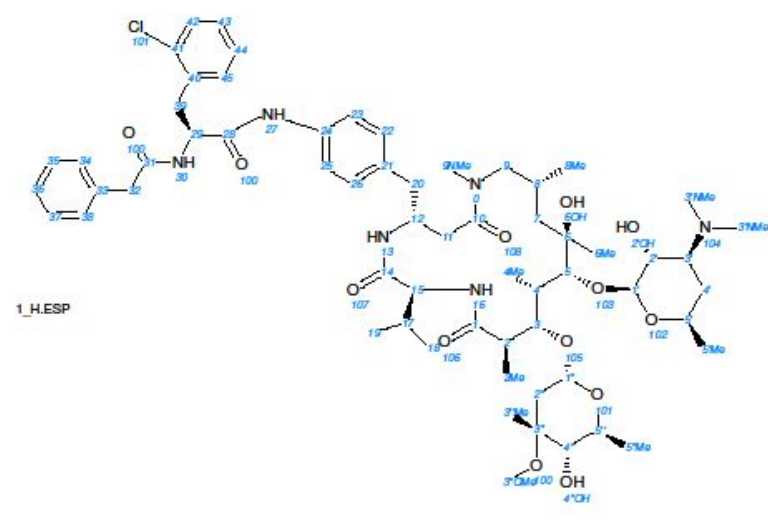

Solvent

Solvent

CHLOROFORM-d

Acquisition Time (sec) $\mathbf{5 . 4 5 2 6}$

Number of Transients 64

Points Count

654536

12019.05

Spectrum Offset $(\mathrm{Hz}) \quad \mathbf{5 3 7 2 . 3 1 3 0}$

Original Points Count $\mathbf{6 5 5 3 6}$

Nucleus

1H

Frequency $(\mathrm{MHz}$

600.13

$36,45,43,35,37,26,22$
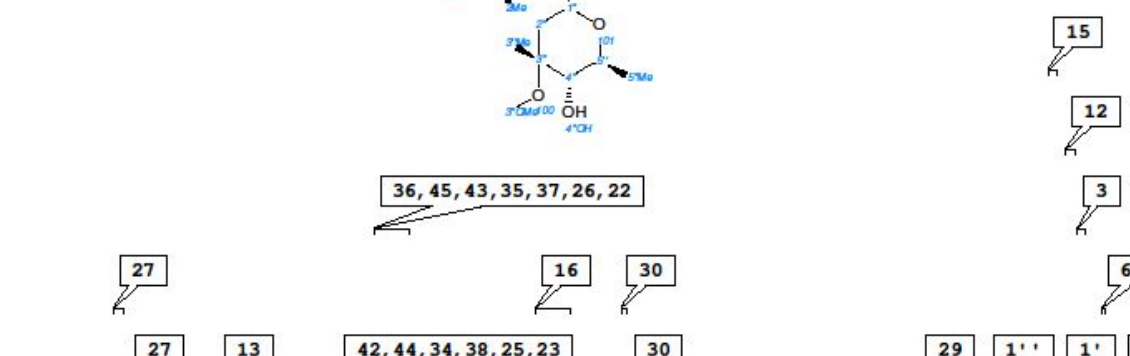

39<'> 20<''>,2,9NMe

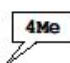

12

3

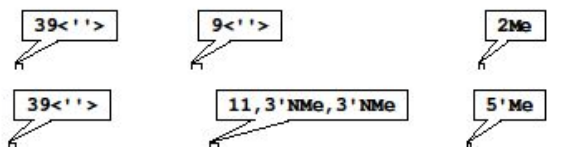

$27 \quad 13 \quad 42,44,34,38,25,23$

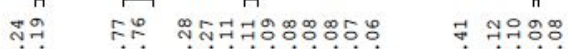

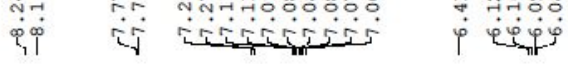

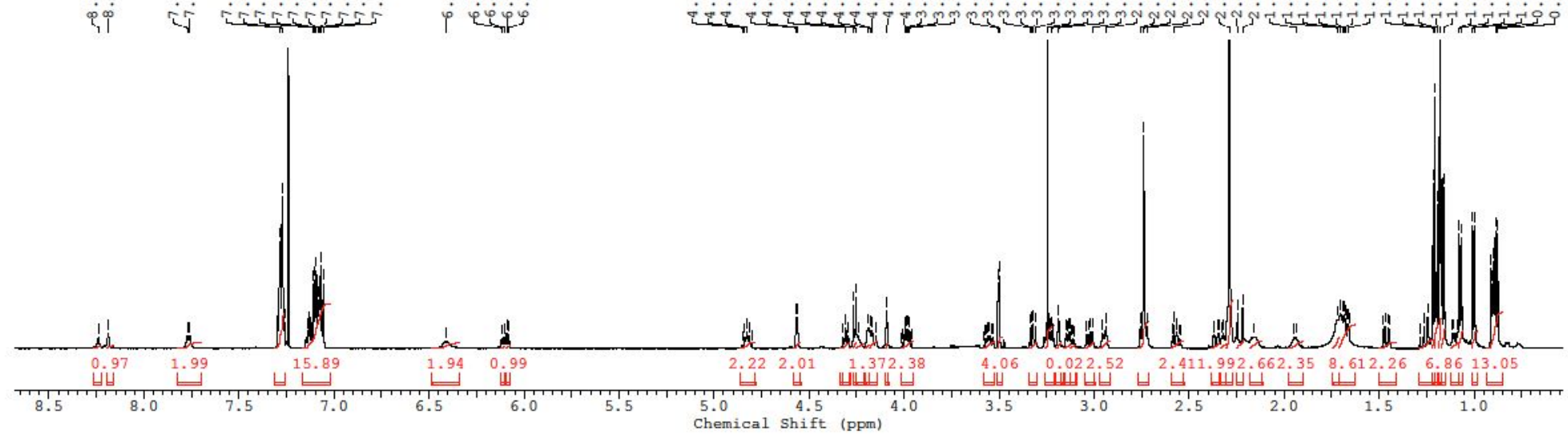


d) ${ }^{13} \mathrm{C}$ NMR spectrum of compound 4 in $\mathrm{CDCl}_{3}$

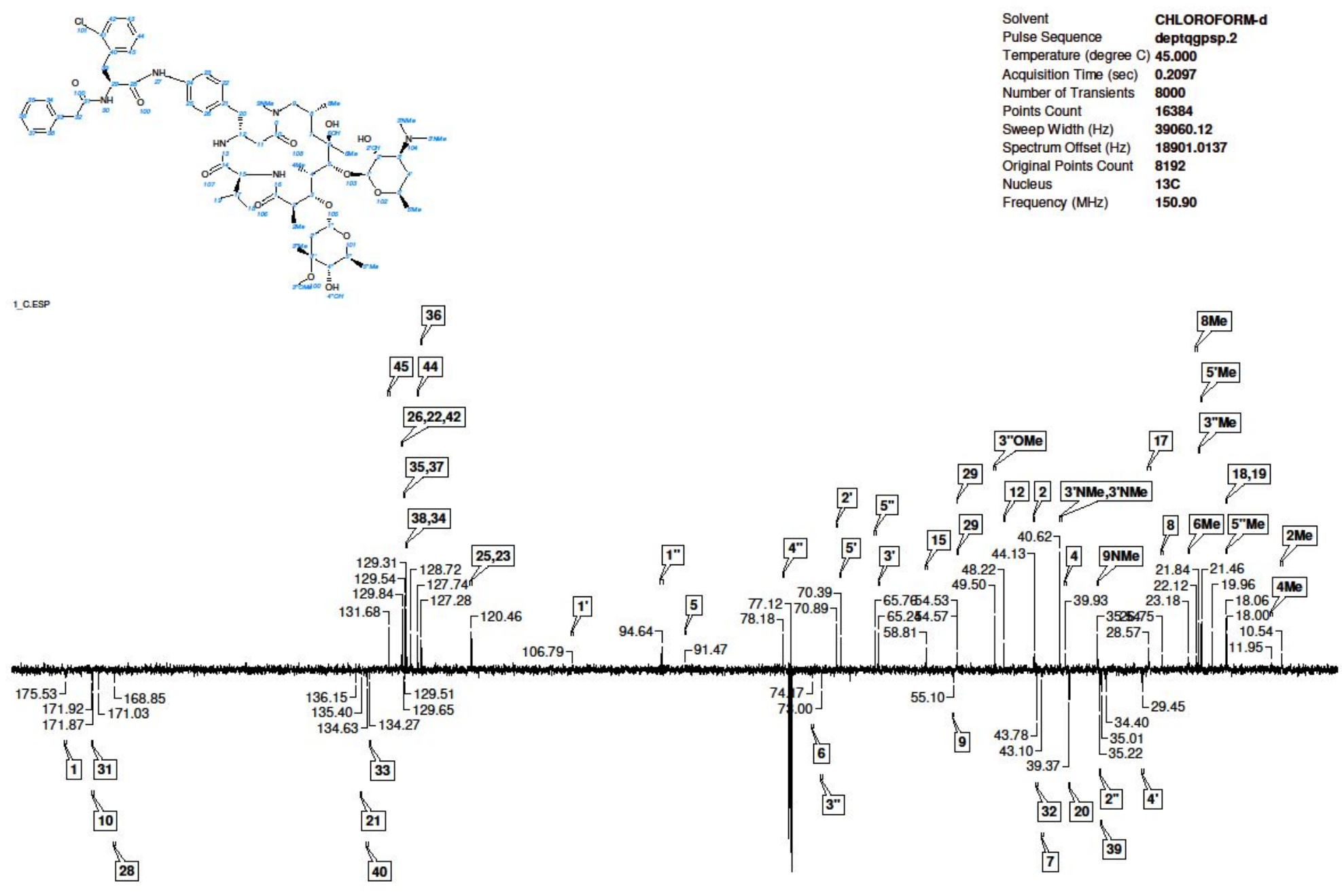

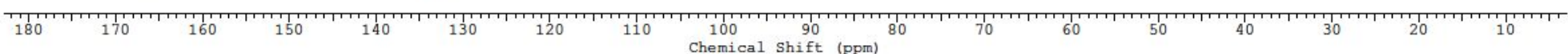


Table S5. Full assignment of compound 4 in buffered $D_{2} 0$ at $25^{\circ} \mathrm{C}$ as preparation for epitope mapping.

\begin{tabular}{|c|c|c|c|}
\hline No. & Atom & ${ }^{1} \mathrm{H}$ chemical shifts (ppm) & ${ }^{13} \mathrm{C}$ chemical shifts (ppm) \\
\hline 1 & $1^{\prime}$ & - & 99.076 \\
\hline 2 & $1 "$ & - & 94.500 \\
\hline 3 & $1^{\prime \prime}<\mathrm{EQ}>$ & 4.700 & - \\
\hline 4 & $1^{\prime}<\mathrm{AX}>$ & 4.552 & - \\
\hline 5 & 2 & 2.690 & 43.475 \\
\hline 6 & $2^{\prime}$ & - & 66.888 \\
\hline 7 & $2 "$ & - & [32.258..32.263] \\
\hline 8 & $2^{\prime \prime}<\mathrm{AX}>$ & 1.589 & - \\
\hline 9 & $2^{\prime \prime}<\mathrm{EQ}>$ & 2.436 & - \\
\hline 10 & $2^{\prime}<\mathrm{AX}>$ & 3.508 & - \\
\hline 11 & $2 \mathrm{Me}$ & 1.177 & 10.357 \\
\hline 12 & 3 & [3.622..3.773] & [77.212..78.579] \\
\hline 13 & $3^{\prime}$ & - & 62.560 \\
\hline 14 & 3"Me & 1.161 & 18.246 \\
\hline 15 & 3"OMe & 3.226 & 46.897 \\
\hline 16 & $3^{\prime}<\mathrm{AX}>$ & 3.414 & - \\
\hline 17 & 4 & 1.986 & 38.837 \\
\hline 18 & $4^{\prime}$ & - & [27.153..27.156] \\
\hline 19 & $4 "$ & - & 74.843 \\
\hline 20 & $4^{\prime \prime}<\mathrm{AX}>$ & 3.134 & - \\
\hline 21 & $4^{\prime}<\mathrm{AX}>$ & 1.505 & - \\
\hline 22 & $4^{\prime}<\mathrm{EQ}>$ & 2.030 & - \\
\hline 23 & $4 \mathrm{Me}$ & [0.932..0.959] & [6.700..7.627] \\
\hline 24 & 5 & 3.465 & 81.842 \\
\hline 25 & $5^{\prime}$ & - & 65.893 \\
\hline 26 & $5 "$ & - & 63.506 \\
\hline 27 & $5^{\prime \prime}<\mathrm{AX}>$ & 4.019 & - \\
\hline 28 & $5 " \mathrm{Me}$ & 1.182 & 15.398 \\
\hline 29 & $5^{\prime}<\mathrm{AX}>$ & 3.817 & - \\
\hline 30 & $5 ' \mathrm{Me}$ & 1.218 & 18.002 \\
\hline 31 & $6 \mathrm{Me}$ & 1.208 & 20.200 \\
\hline 32 & 7 & 1.245 & 37.971 \\
\hline 33 & 8 & {$[2.036 . .2 .110]$} & [24.947..25.055] \\
\hline 34 & $8 \mathrm{Me}$ & {$[0.935 . .0 .966]$} & [16.266..17.541] \\
\hline 35 & 9 & - & [55.199..55.202] \\
\hline 36 & $9<">$ & 2.996 & - \\
\hline 37 & $9<'>$ & 3.323 & - \\
\hline 38 & 9NMe & [2.831..2.953] & [31.812..34.186] \\
\hline 39 & 11 & 2.655 & 37.431 \\
\hline 40 & 12 & 4.332 & 46.893 \\
\hline 41 & 15 & 3.810 & 57.537 \\
\hline 42 & 17 & 1.591 & 27.573 \\
\hline 43 & 18 & 0.350 & 15.914 \\
\hline 44 & 19 & 0.509 & 15.344 \\
\hline 45 & 20 & - & [36.845..36.851] \\
\hline 46 & $20<">$ & 2.612 & - \\
\hline 47 & $20<'>$ & 3.011 & - \\
\hline 48 & 22 & 7.131 & 127.502 \\
\hline 49 & 23 & 7.075 & 120.117 \\
\hline 50 & 25 & 7.075 & 120.117 \\
\hline 51 & 26 & 7.131 & 127.502 \\
\hline 52 & 29 & 4.680 & 52.165 \\
\hline 53 & 32 & 3.557 & 39.965 \\
\hline 54 & 34 & 7.160 & 126.926 \\
\hline 55 & 35 & 7.297 & 126.763 \\
\hline 56 & 36 & 7.261 & 125.163 \\
\hline 57 & 37 & 7.297 & 126.763 \\
\hline 58 & 38 & 7.160 & 126.926 \\
\hline 59 & 39 & 3.210 & 32.924 \\
\hline 60 & 42 & 7.356 & 127.496 \\
\hline 61 & 43 & 7.200 & 126.763 \\
\hline 62 & 44 & 7.160 & 125.161 \\
\hline 63 & 45 & 7.181 & 129.613 \\
\hline
\end{tabular}


Table S6. Structural properties of most advanced compounds compared with guidelines for macrocyclic compounds. ${ }^{1,2}$

\begin{tabular}{lllllll}
\hline & & & & & \multicolumn{2}{c}{ Guidelines for MC } \\
Descriptor & $\mathbf{4}$ & $\mathbf{4 8}$ & $\mathbf{4 9}$ & $\mathbf{5 6}$ & Villar $^{1}$ & Khilberg $^{2}$ \\
\hline MW & 1163.9 & 1164.9 & 1178.9 & 1086.6 & $600-1200$ & $<1000$ \\
cLogP & 5.5 & 5.7 & 5.7 & 4.1 & $-2-6$ & $<10$ \\
cLogD & 4.7 & 4.9 & 4.8 & 3.2 & & \\
HBA & 19 & 20 & 20 & 19 & $12-16$ & \\
HBD & 7 & 8 & 8 & 7 & $\leq 12$ & $<5$ \\
PSA & 247 & 259 & 259 & 247 & $180-320$ & $<250$ \\
NRB & 16 & 15 & 16 & 14 & $\leq 15$ & \\
Polar/nonpolar & 0.32 & 0.34 & 0.34 & 0.25 & 0.3 & \\
\hline
\end{tabular}


FIGURES

a)

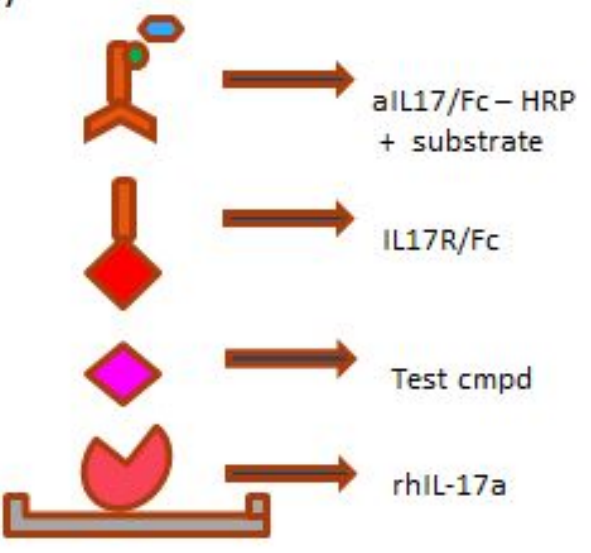

b)

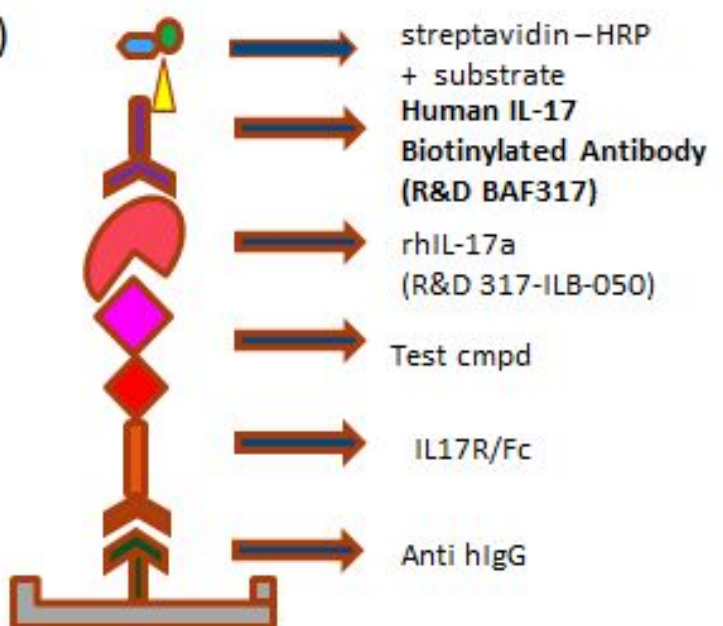

Figure S1. Schematic presentation of protein binding ELISA biochemical assays, in which (a) compounds were incubated with IL-17A (ELISA-I) and (b) with IL-17RA (ELISA-II). 
HSQC.ESP

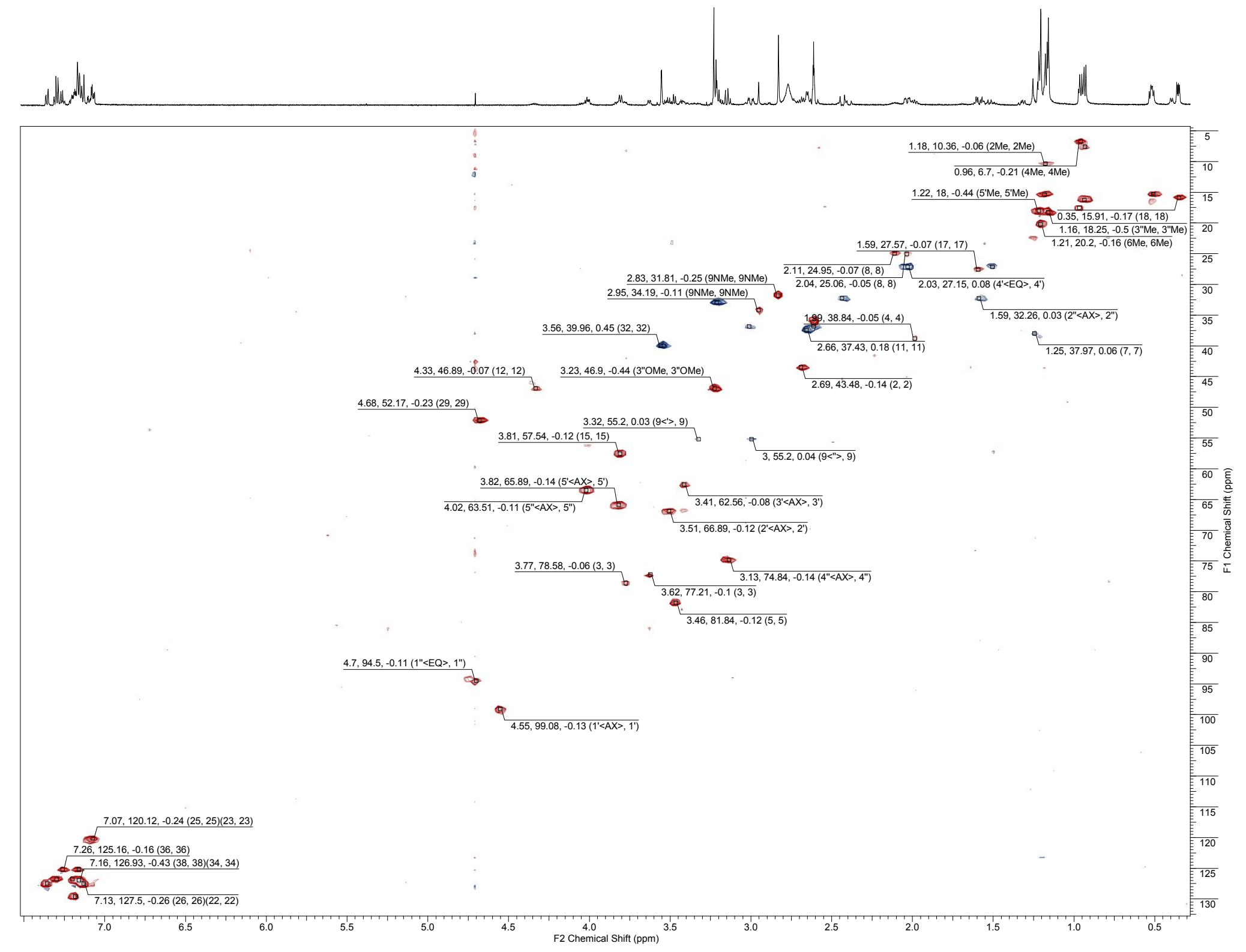

Figure S2. Fully assigned ${ }^{1} \mathrm{H}^{13} \mathrm{C} \quad \mathrm{HSQC}$ spectrum of compound 4 in buffered $\mathrm{D}_{2} \mathrm{O}$ at $25^{\circ} \mathrm{C}$. 


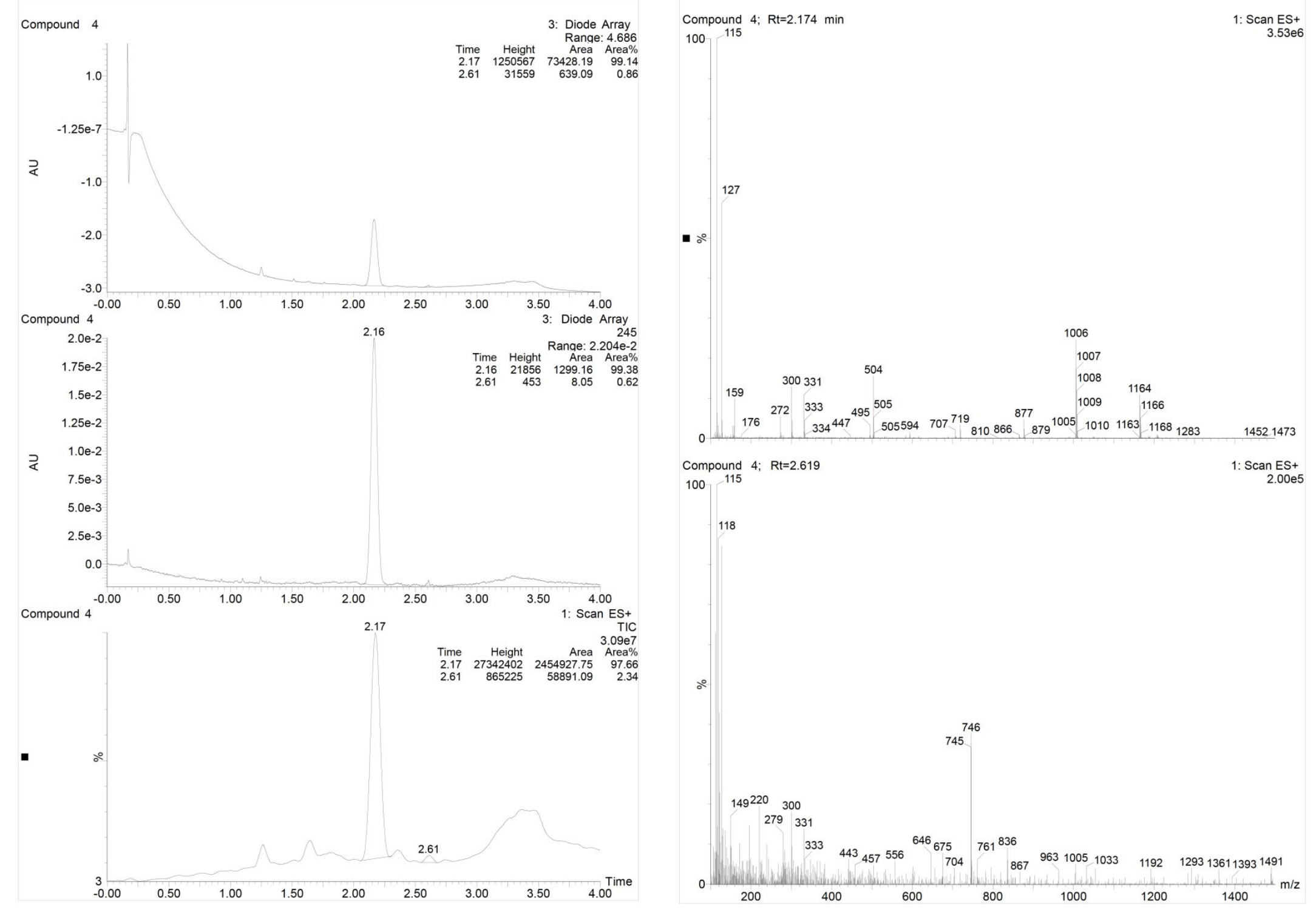

Figure S3. UPLC-MS of compound 4. 

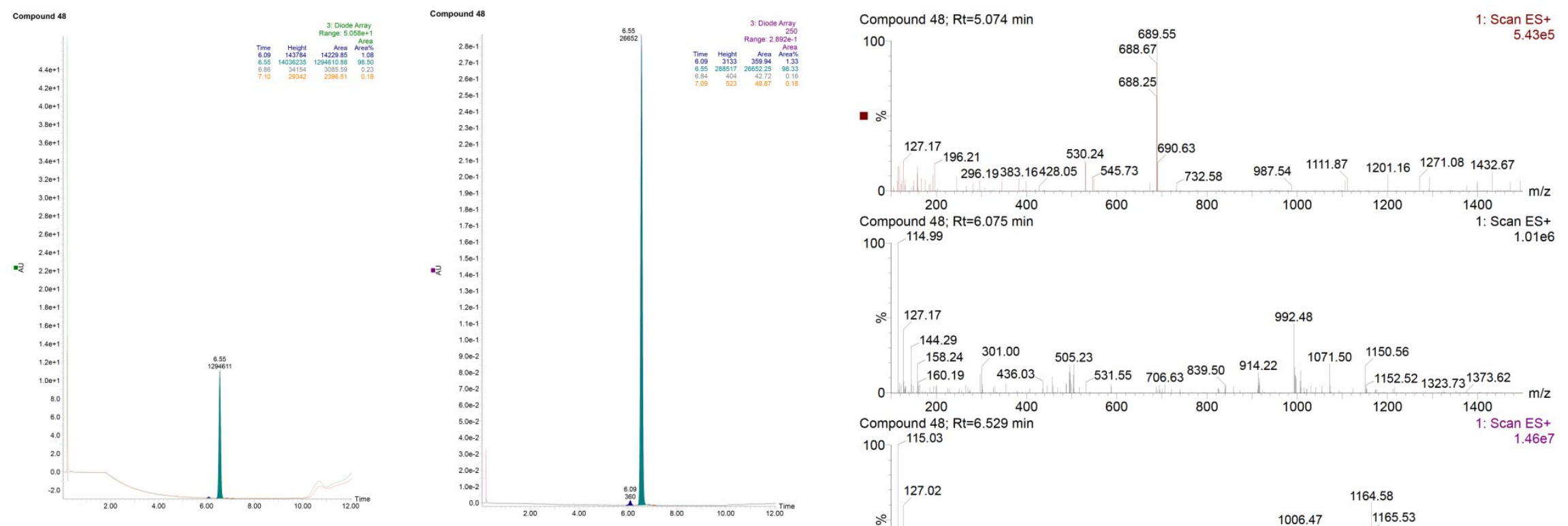
$\begin{array}{ccccccc}200 & 400 & 600 & 800 & 1000 & 1200 & 1400 \\ \begin{array}{c}\text { Compound } 48 ; \mathrm{Rt}=6.075 \mathrm{~min} \\ 114.99\end{array} & & & & & 1: \text { Scan ES+ } \\ 100\end{array}$ 100

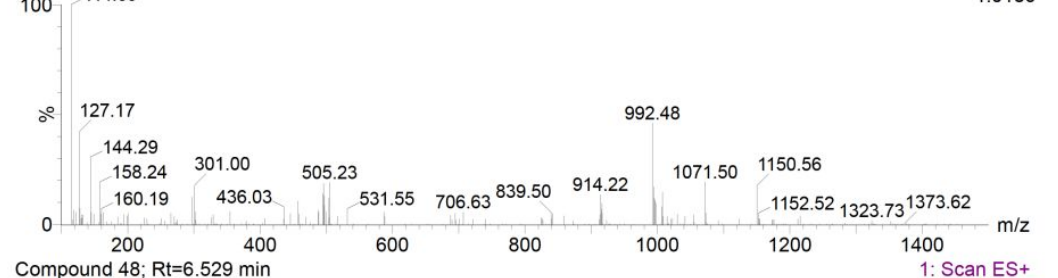
$\begin{array}{lrr}\text { Compound } 48 ; \mathrm{Rt}=6.529 \mathrm{~min} & 1000 \\ 100 \quad 115.03 & 1: \text { Scan ES+ } \\ 1.46 \mathrm{e} 7\end{array}$

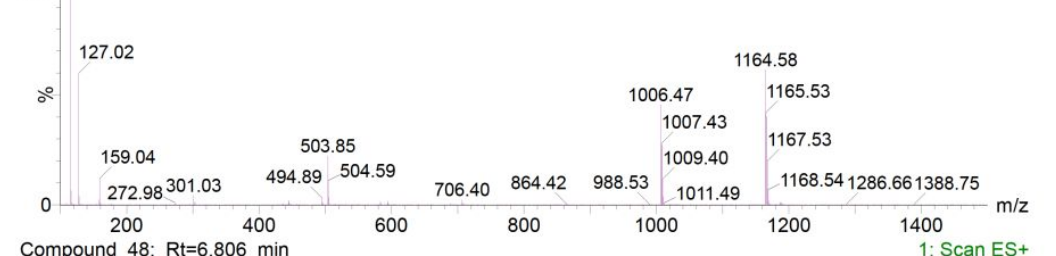

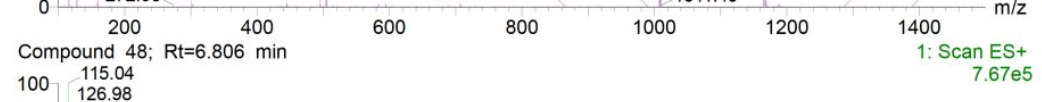

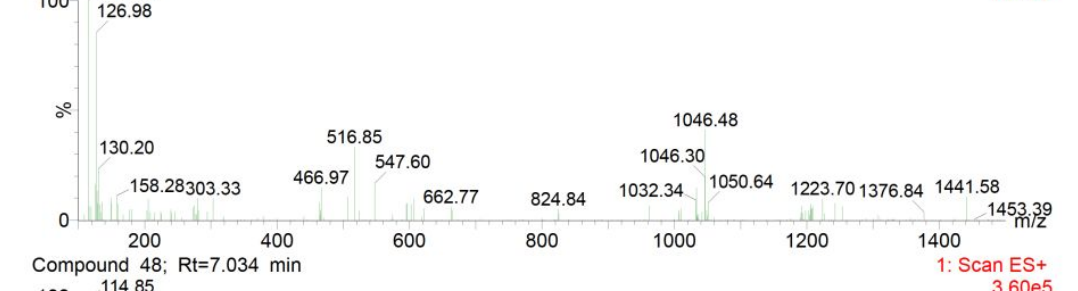

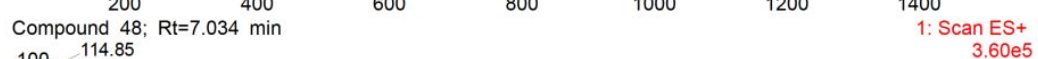
$100 \stackrel{114.85}{127.17}$

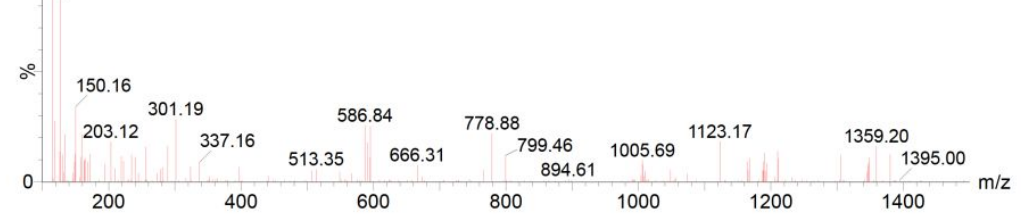

Figure S4. UPLC-MS of compound 48. 

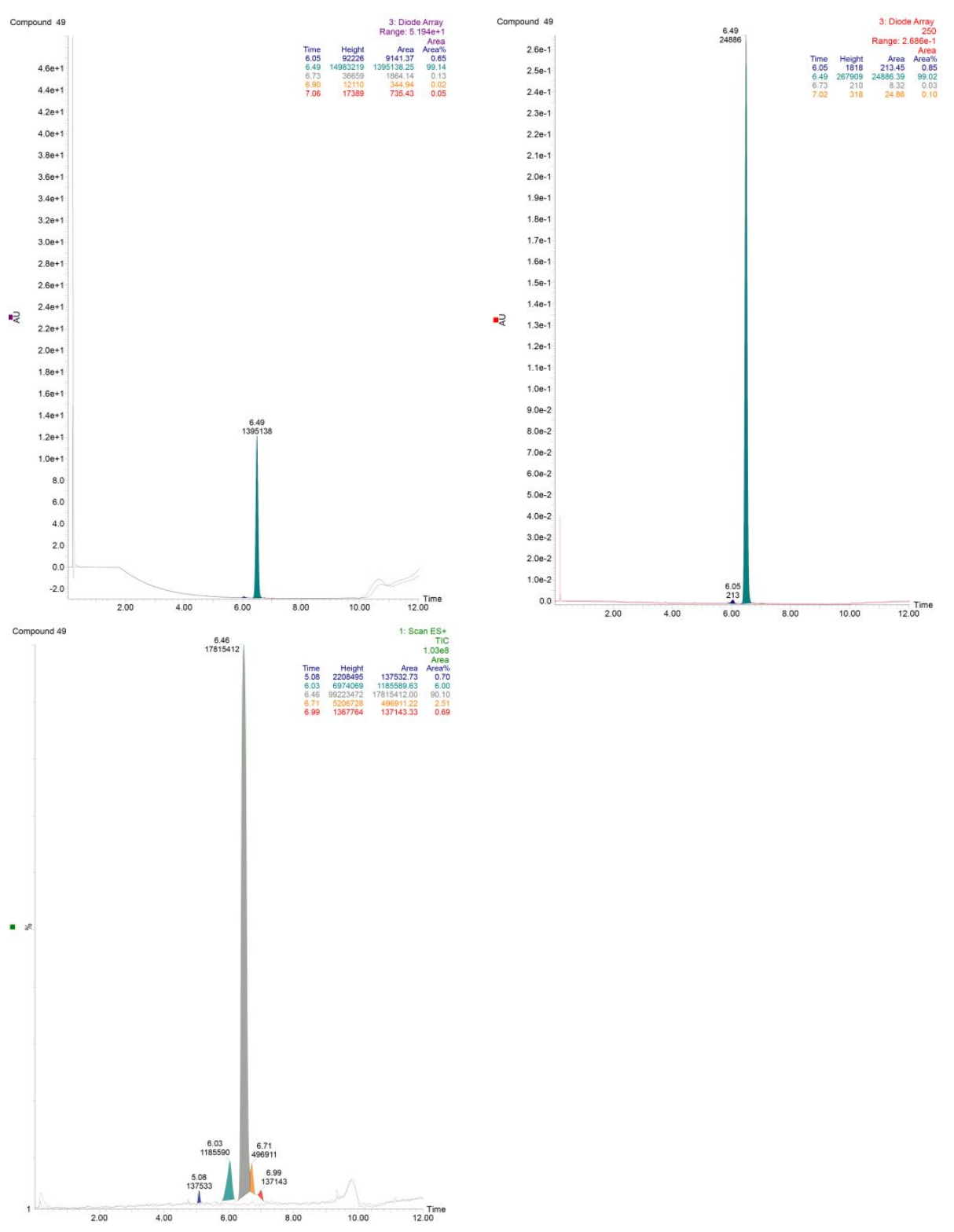

Compound 49; Rt=5.091 $\mathrm{min}$

100

688.34

1: Scan ES+

100

89.51

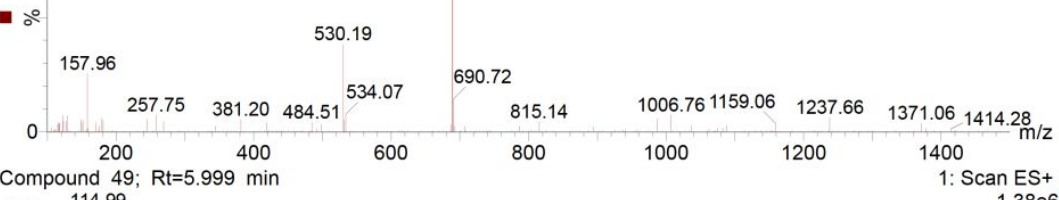
Compound 49; Rt=5.999 $\mathrm{min}$ $100-114$

127.03

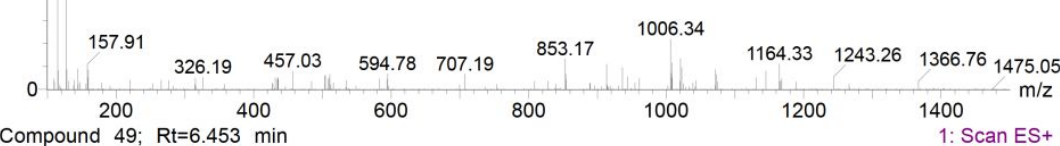
$\begin{array}{rl}\text { Compound 49; Rt=6.453 } \mathrm{min} & 1: \text { Scan ES+ } \\ 1.39 & \end{array}$ $100115.03 \quad 1.39 \mathrm{e}$

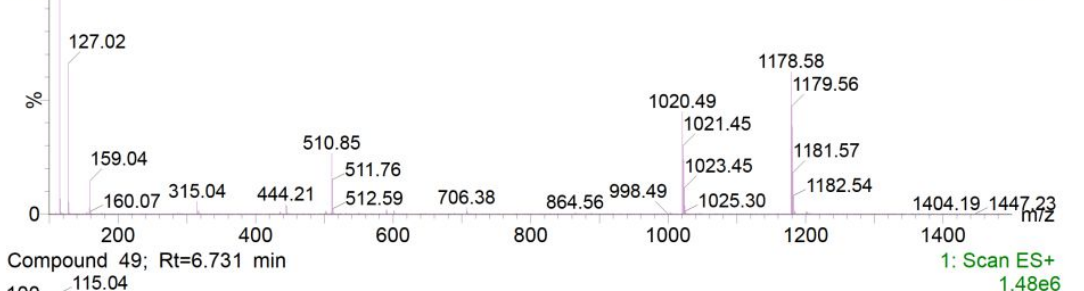
$\begin{array}{lr}\begin{array}{l}\text { Compound } 49 ; \mathrm{Rt}=6.731 \mathrm{~min} \\ 100 \\ 115.04\end{array} & 1: \text { Scan ES+ } \\ 1.48 \mathrm{e} 6\end{array}$

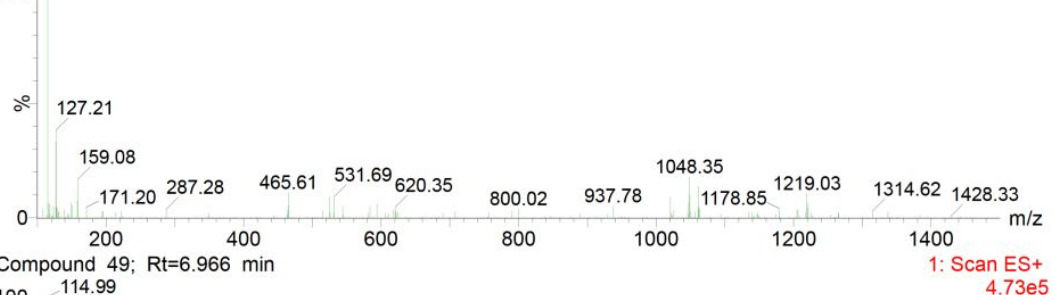

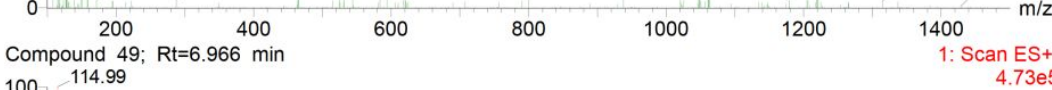
100

\begin{tabular}{|c|c|c|c|c|c|c|}
\hline \multirow{2}{*}{158.52290 .83} & \multicolumn{3}{|c|}{601.22} & \multicolumn{2}{|l|}{1023.43} & \multirow{2}{*}{1475.98} \\
\hline & 435.94 & 706.12 & 898.26 & 1022.68 & 1201.621312 .66 & \\
\hline 200 & 400 & & 00 & 1000 & 1200 & 00 \\
\hline
\end{tabular}


Figure S5. UPLC-MS of compound 49.

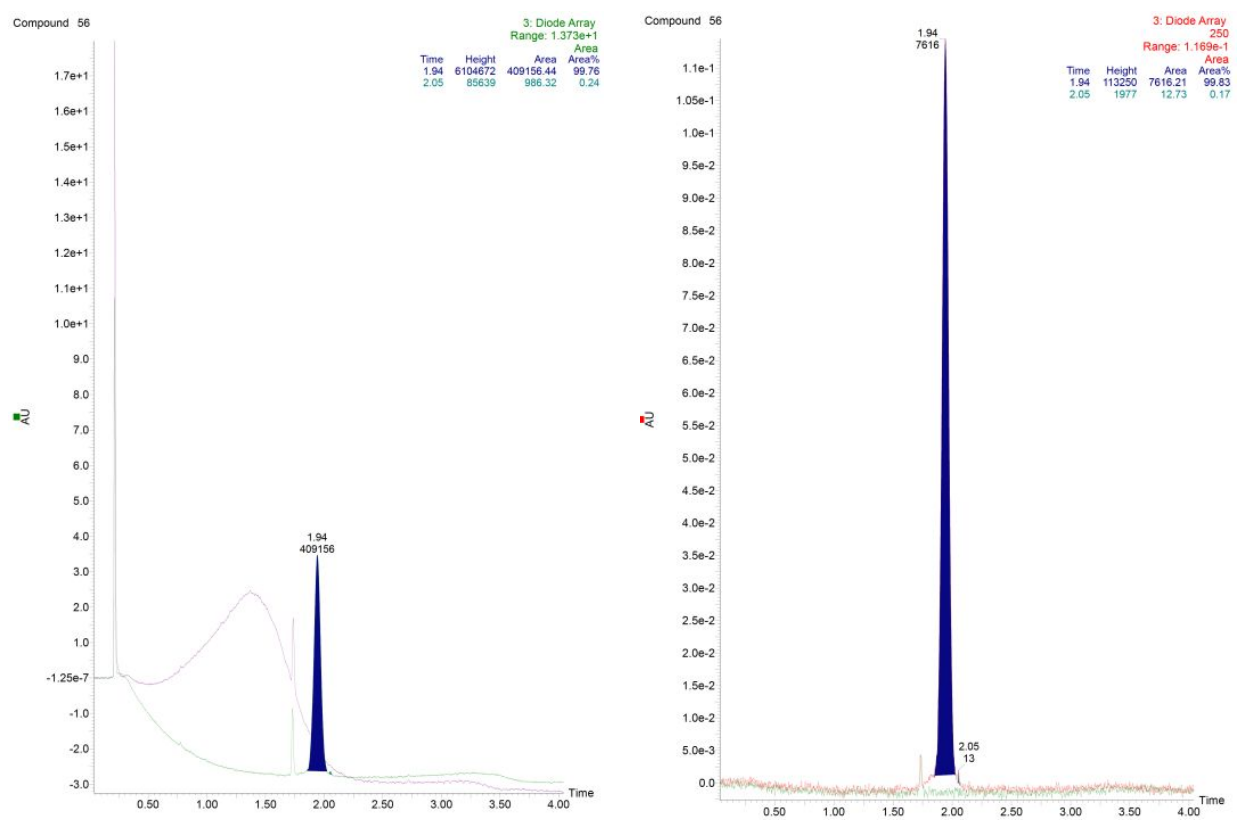

S29 


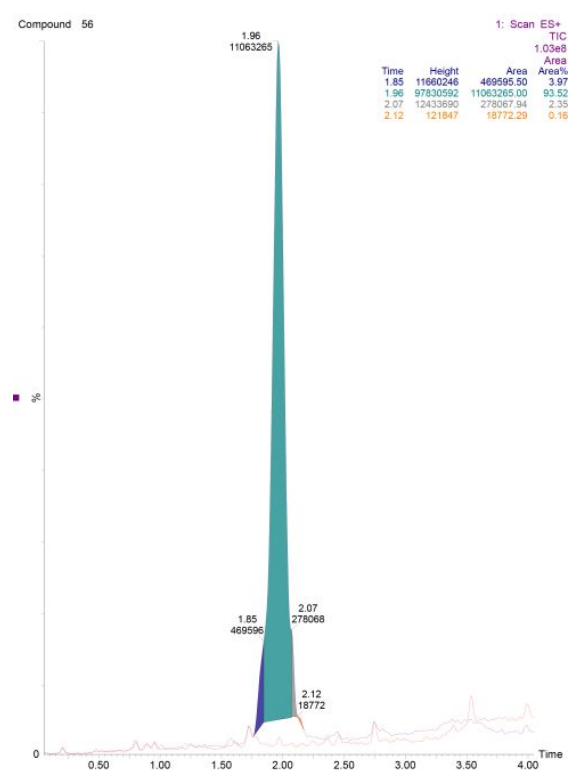

Compound 56; Rt=1.762 min

1: Scan ES+
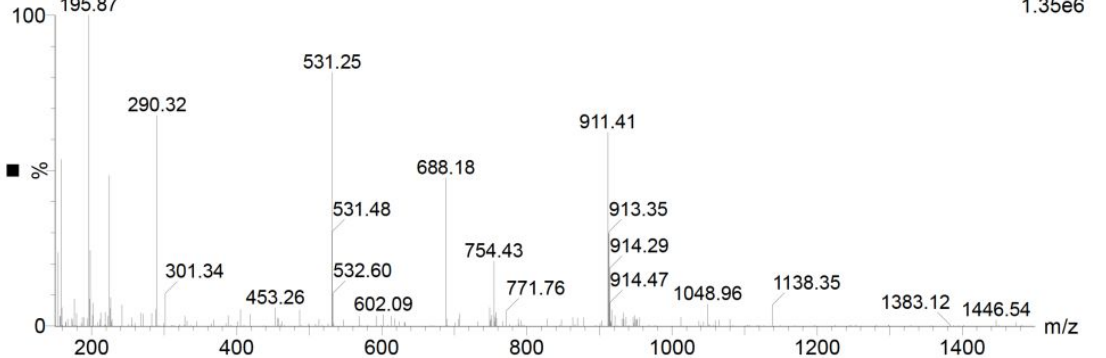
Compound 56. Rt=1.904 min

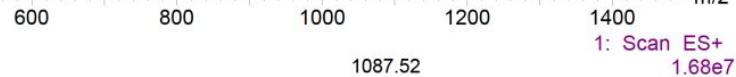

100

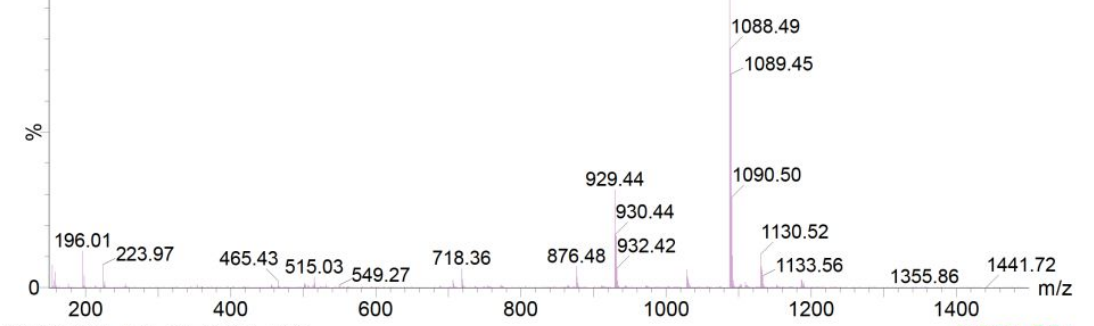

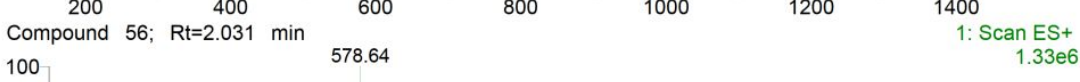
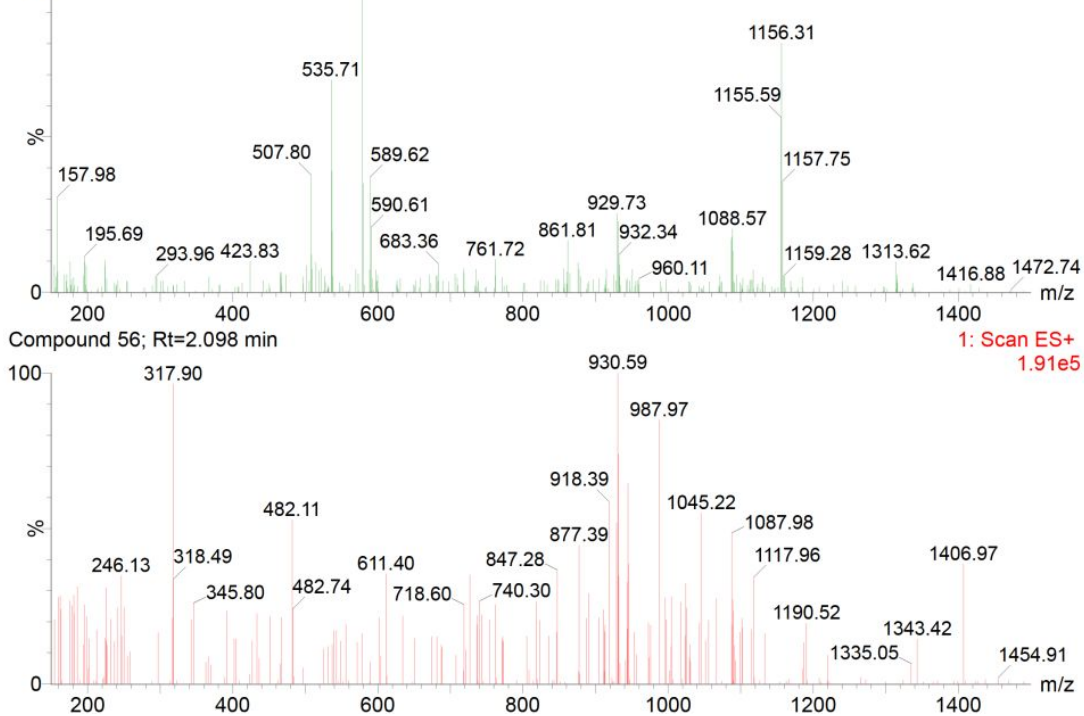

Figure S6. UPLC-MS of compound 56. 
a)
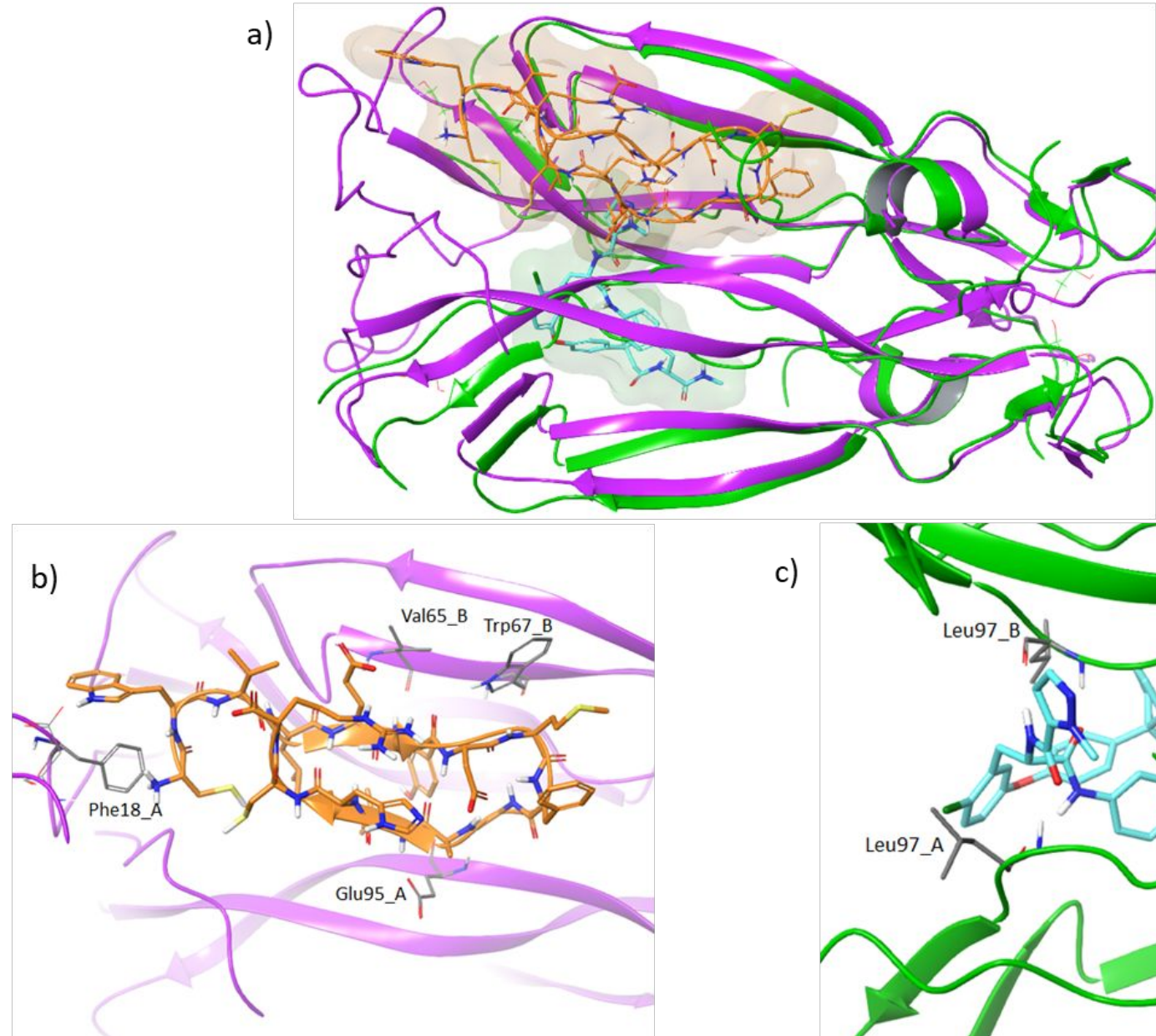

c)

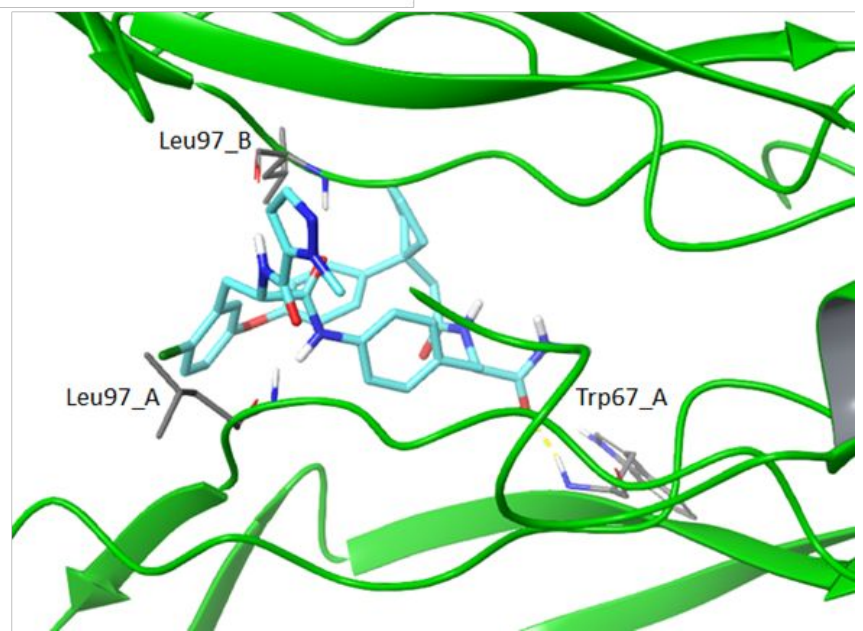

Figure S7. Available X-ray structures of IL-17A homodimer in complex with macrocyclic inhibitors: a) PDB: 5 VB9 (magenta) ${ }^{3}$ aligned with PDB: 5 HI4 (green) ${ }^{4}$, b) enlarged binding pocket of PDB: 5VB93 3 c) enlarged binding pocket of PDB: 5HI44. 


\section{NMR METHODS}

\section{Conformational analysis}

The conformational analyses were performed in different solvents and at different temperatures, depending on the solubility of each compound and broadness of the resonance lines in the proton spectrum. The tool compound was analysed in DMSO$\mathrm{d}_{6}$ at $25^{\circ} \mathrm{C}$ and compound 4 in $\mathrm{CDCl}_{3}$ at $45^{\circ} \mathrm{C}$. Conformational analysis was performed using combination of coupling constants and nOe interactions, both listed in Supporting Information.

\section{Epitope mapping of compound 4 interacting with human IL-17}

According to the producer instructions (R\&D Systems), the lyophilised recombinant human IL-17 protein needs to be reconstituted at $100 \mu \mathrm{g} / \mathrm{ml}$ in $4 \mathrm{mM} \mathrm{HCl}$ giving stock solution with concentration of $3.13 \mu \mathrm{M}$. In highly acidic conditions (like pH 2.4 of $4 \mathrm{mM} \mathrm{DCl}$ ) compound 4 is unstable (cleavage of glycoside bond between the macrocycle and cladinose sugar). Therefore, the compound was dissolved in $4 \mathrm{mM} \mathrm{DCl}$ with modified pH to 4.1 and its stability tested over time. Proton spectrum was recorded immediately after sample prep $\left(\mathrm{T}_{0}\right)$ and then in time intervals of $\mathrm{T}_{0}+16 \mathrm{~h}$ and $\mathrm{T}_{0}+32 \mathrm{~h}$. Compound 4 proved to be stable at $\mathrm{pH} 4.1$ for at least $32 \mathrm{~h}$.

For STD NMR experiments $5 \mu \mathrm{l}$ of compound $4(200 \mathrm{mM})$ were diluted with $160 \mu \mathrm{l}$ of $4 \mathrm{mM} \mathrm{DCl}(\mathrm{pH} 2.4), 345 \mu \mathrm{l} 4 \mathrm{mM} \mathrm{DCl}$ (pH 4.1) and $4.43 \mu \mathrm{l} 0.1 \mathrm{mM}$ NaOD to give the final $\mathrm{pH}$ of 4.1 with $0.98 \%$ DMSO- $_{6}$. Since the solution contained a lot of unsolved compound, sample was centrifuged for $2 \mathrm{~min}$ at $10000 \mathrm{rcf}$ and $21^{\circ} \mathrm{C}$. Therefore, the final compound concentration was between $0.5 \mathrm{mM}$ and $2 \mathrm{mM}$ and sample was recorded in $5 \mathrm{~mm}$ NMR tube.

In parallel, $160 \mu \mathrm{l}$ of recombinant human IL-17 protein stock solution (3.13 $\mu \mathrm{M}$ or $100 \mu \mathrm{g} / \mathrm{ml}$ in $4 \mathrm{mM} \mathrm{DCl}, \mathrm{pH} 2.4)$ was diluted with $345 \mu \mathrm{l} 4 \mathrm{mM} \mathrm{DCl} \mathrm{(pH} \mathrm{4.1)} \mathrm{and} 4.43 \mu \mathrm{l} 0.1 \mathrm{mM} \mathrm{NaOD}$ to give the final solution $\mathrm{pH}$ of 4.1. To the solution $5 \mu \mathrm{l}$ of compound $4(200 \mathrm{mM})$ was added. Since the solution contained a lot of unsolved compound, sample was centrifuged for 2 min at 10000 rcf and $21^{\circ} \mathrm{C}$. Therefore, the final compound concentration was between $0.5 \mathrm{mM}$ and $2 \mathrm{mM}$ and sample was recorded in 5 $\mathrm{mm}$ NMR tube. Final protein concentration was $0.98 \mu \mathrm{M}$ giving protein to ligand ratio of 1:500-2000.

STD NMR experiments with human IL-17 protein were set-up as 220 successive 32 scan experiments with total duration of $64 \mathrm{~h}$. Viability of the human IL-17 protein was tested for the period of $64 \mathrm{~h}$ during which the STD NMR signals retained approximately the same intensity pointing to good stability of the protein. 


\section{COMPUTATIONAL METHODS}

Available crystal structures of IL17A dimer apo structure (PDB: 4HR9), in complex with IL17R (PDB: 4HSA), in complex with antibodies (PDB: 2VSX, 4QHU) and in complex with linear and macrocyclic inhibitors (PDB: 5HI3, 5HI4, 5VB9) were downloaded from the Protein Data Bank. ${ }^{5}$

The ligand docking studies were carried out using Glide ${ }^{6,7}$ docking protocol within Schrödinger software suite ${ }^{8}$ with and without extra precision (SP, XP). Flexible docking, rigid docking and flexible docking without sampling macrocyclic conformations were explored.

To generate hypothesis 1 , due to the size of the tool compound and compound 4, a 3-step docking procedure was used. Initially only the macrocycle with the aniline ring from the linear side chain was docked to explore binding poses in agreement with the known SAR, especially the tight SAR around the cyclopentyl moiety which indicated a buried position in the lipophilic pocket. Secondly, the substituted phenylalanine was added and finally the terminal aromatic ring containing amide group. This process enabled us to add the constrained interaction into the docking procedure, namely to constrain the position of the cyclopentyl moiety in the small lipophilic pocket and the formed H-bonds. Flexible docking was used for the linear side chain, while macrocyclic conformations were not sampled during the docking process.

To generate hypothesis 2, hydrogen bond constrains were used from 5HI4 x-ray structure, flexible docking was applied for linear side chain while macrocyclic conformations were slightly relaxed within $1 \mathrm{kcal} / \mathrm{mol}$ energy window. Docking of compound 4 was performed stepwise, with and without sugars, in order to obtain hydrogen bonding pattern from 5HI4 structure.

Binding poses were refined and binding energies estimated using MM-GBSA ${ }^{9,10}$ and OPLS3 force-field ${ }^{11}$ with flexible residues distance being $6 \AA$. 


\author{
Standard compounds \\ MC15912 (Figure 1) and, consequently, compound 4 were used as standard compounds.
}

\title{
Compound preparation
}

Standard compounds and all test compounds were dissolved in pure DMSO to obtained 10 mM concentration stock solutions. Mother plates (96-well V plates; Greiner) with serial dilutions from $10 \mathrm{mM}$ stock solutions were prepared on Janus automatic pipetting workstation (Perkin-Elmer), diluted 1:3. Working plates (high-binding 96-well plates, \#9018 Costar) were prepared with transferring $500 \mathrm{nl}$ of each dilution to working plates using Mosquito (TTP Labtech) keeping constant low concentration of DMSO in each well (up to $0.3 \%$ ). Compounds were tested in duplicates, in dose-dependent manner of 10 or 5 concentrations and starting concentrations 100, 30 or $10 \mathrm{uM}$ depends of the assay. Standard compounds were tested in 10 concentration in all assays, compound 4 starting from $30 \mu \mathrm{M}$ and tool compound starting from $10 \mu \mathrm{M}$.

\section{ELISA-I}

Recombinant hIL-17 (\#317-ILB) and hIL-17R+Fc (\#177-IR) were purchased from R\&D Systems; HRP-conjugated anti-human Fc (\#04-10-20) was obtained from KPL, and protein blocking buffer (\#37573) from ThermoScientific. PBS (\#P2287), Tween 20 (\#P2287) and TMB (\#T2885) were purchased from Sigma (EU or Germany). Compounds were tested in 5 concentrations with starting concentration $10 \mu \mathrm{M}$. Human ELISA-I was performed as follows in duplicate unless otherwise specified. Plates were coated with $20 \mathrm{nM}$ rhIL-17 in PBS (100 $\mu \mathrm{l}$ per well). Subsequent incubations were for 30 min at room temperature on shaker. Plates were washed 3x between steps by adding $250 \mu \mathrm{l}$ of PBS-T per well using Multidrop plate washer. Protein free blocking buffer $(250 \mu \mathrm{l} /$ well) was added and after incubation and washing, $300 \mathrm{nl}$ of compounds from dose-response mother plates was added into $75 \mu \mathrm{l}$ of PBS-T on working plate, followed with adding of $25 \mu \mathrm{l}$ of $12 \mathrm{nM}$ IL-17 receptor + Fc in PBS-T per well. Positive controls were wells with no compounds and negative control wells with no IL-17 receptor + Fc added. HRPconjugated anti-human Fc (100 $\mu \mathrm{l}$ per well; $50 \mathrm{ng} / \mathrm{ml})$ was added. After incubation and washing, TMB substrate was added $(100 \mu \mathrm{l} /$ well $)$ and after blue colour was developed, reactions were stopped (0.5 N HCl, $100 \mu \mathrm{l} /$ well) and an OD450 values were read on EnVision plate reader (PE).

\section{ELISA-II}

Recombinant hIL-17 antibody coupled with biotin (\#BAF317), hIL-17R+Fc (\#177-IR) and recombinant hIL-17 (\#317-ILB) were purchased from R\&D Systems; anti-human IgG (\#01-10-02) and streptavidin-HRP (\#14-30-30) were obtained from KPL, and protein blocking buffer (\#37573) from ThermoScientific. PBS (\#P2287), Tween 20 (\#P2287) and TMB (\#T2885) were purchased from Sigma (EU or Germany). Compounds were tested in 5 concentrations with starting concentration 30 $\mu \mathrm{M}$. Human ELISA-II was performed as follows in duplicate unless otherwise specified. Plates were coated with $20 \mathrm{nM}$ antihuman IgG in PBS $(100 \mu \mathrm{L} /$ well). Subsequent incubations were for $30 \mathrm{~min}$ at room temperature on shaker. Plates were washed $3 x$ between steps by adding $250 \mu$ of PBS-T per well using Multidrop plate washer. Protein free blocking buffer (250 $\mu \mathrm{L} /$ well) was added. After incubation and washing, $100 \mu \mathrm{l}$ per well of 10nM IL-17 receptor + Fc in PBS-T was added followed with adding $300 \mathrm{nl}$ of compounds from dose-response mother plates into $75 \mu \mathrm{l}$ of PBS-T on working plate and of $25 \mu \mathrm{l}$ per well of $20 \mathrm{nM}$ recombinant human IL-17 in PBS-T. Positive controls were wells with no compound and negative control wells with no IL-17 receptor + Fc. In next step, $0.2 \mu \mathrm{g} / \mathrm{ml}$ recombinant human IL-17 - biotin antibody in PBS-T was added. After incubation and washing, $25 \mathrm{ng} / \mathrm{ml}$ streptavidin-HRP in PBS-T (100 $\mu \mathrm{L} /$ well $)$ was added. Reaction was developed by adding TMB substrate $(100 \mu \mathrm{l} /$ well $)$, stopped $(0.5 \mathrm{~N} \mathrm{HCl}, 100 \mu \mathrm{L} /$ well $)$ and an OD450 values were read on EnVision plate reader (PE).

\section{Functional assay screening}

Primary human epidermal keratinocytes (HEKa) were grown in Epilife medium with full supplement (including hydrocortisone). One day before the experiment cells were suspended in supplement-containing medium without hydrocordisone and seeded (3500 cells/well) in 384-well plates. Plates were incubated at $37^{\circ} \mathrm{C}$ in a humidified atmosphere with $5 \% \mathrm{CO}_{2}$. On the following day plates were emptied and medium replaced (without hydrocortisone). Test compounds were diluted in DMSO, and transferred into the wells containing HEKa cells. All wells, including control wells, received $0.1 \%$ DMSO. This was followed by small volume of medium, in order to ensure mixing. Plates were incubated for $2 \mathrm{~h}$ and then stimulated with a mixture of TNF-a and IL-17 (both expressed in E. coli; R\&D Systems 210-TA and 317-ILB) to give a final concentration of $10 \mathrm{ng} / \mathrm{ml}$ of each cytokine. Plates were further incubated for 3 days. A small amount of supernatant was removed to quantify IL8 by homogenous time-resolved fluorescence (HTRF) FRET assay (CisBio). Concentration response curves were fitted with a four-parameter logistic equation. IL-8 levels achieved by TNF-a stimulation alone were defined as $100 \%$ effect of inhibition of IL-17. 


\section{MDCKII-MDR1 permeability assay}

MDCKII-hMDR1 cells were obtained from Solvo Biotechnology, Hungary. DMEM, Fetal bovine serum, Glutamax-100, Antibiotic/Antimycotic, DMSO, Dulbecco's phosphate buffer saline, MEM Non-essential amino acids were purchased from Sigma (St. Louis, MO, USA). Bi-directional permeability and P-glycoprotein substrate assessment were investigated in MadinDarby canine epithelial cells with over-expressed human MDR1 gene (MDCKII-MDR1), coding for P-glycoprotein. Experimental procedures, as well as cell culture conditions, were the same as previously described. ${ }^{13}$ Briefly, compounds (10 $\mu \mathrm{M}, 1 \% \mathrm{DMSO} \mathrm{v} / \mathrm{v}$ ) in duplicate were incubated at $37^{\circ} \mathrm{C}$ for $1 \mathrm{~h}$ with cell monolayer on 24-well Millicell inserts (Millipore, Burlington, MA, USA) without and with the P-glycoprotein inhibitor Elacridar ( $2 \mu \mathrm{M}$, International Laboratory, USA). Inhibition of P-glycoprotein was verified by amprenavir (Moravek Biochemicals Inc, Brea, CA, USA) and monolayer integrity by Lucifer yellow (Sigma, St. Louis, MO, USA). Compound concentrations were measured by LC-MS/MS and Lucifer yellow was measured on an Infinite F500 (Tecan, Männedorf, CH) using excitation of $485 \mathrm{~nm}$ and emission of $530 \mathrm{~nm}$.

\section{Metabolic stability}

Metabolic stability was assessed in mouse and human liver microsomes. Compounds (final concentration of $1 \mu \mathrm{M}, 0.1 \%$ DMSO $\mathrm{v} / \mathrm{v}$ ) were incubated in duplicate in phosphate buffer $(50 \mathrm{mM}, \mathrm{pH} 7.4)$ at $37^{\circ} \mathrm{C}$ for $1 \mathrm{~h}$ with liver microsomes (BD Biosciences) in the absence and presence of the NADPH cofactor. Aliquots were taken at 0,10, 20, 30, 45 and 60 min, and reaction was terminated by addition of a $\mathrm{MeCN} / \mathrm{MeOH}$ (2:1) mixture, containing internal standard. Aliquots were then centrifuged and resulting supernatants were subjected to LC/MS/MS analysis under conditions stated at the end of this section. Metabolic activity of microsomes was verified by simultaneous analysis of testosterone and propranolol as controls.

The results were presented as predicted in vivo hepatic clearance (expressed as \% liver blood).

The in vitro half-life $\left(t_{1 / 2}\right)$ was calculated from the slope of the linear regression by plotting $\ln (\%$ remaining of parent compound) against incubation time.

In vitro intrinsic clearance $\left(\mathrm{CL}_{\text {int }}\right)$ was calculated from in vitro half-life using following equation:

$\mathrm{CL}_{\text {int }}\left[\mu \mathrm{lmin}^{-1} \mathrm{mg}^{-1}\right]=\frac{\ln 2}{\mathrm{t}^{1 / 2}} \times \frac{\mathrm{ml} \text { per incubation }}{\mathrm{mg} \text { protein per incubation }}$

where $52.5 \mathrm{mg}$ protein/g liver was used as a constant.

Predicted in vivo hepatic clearance (in vivo $\mathrm{CL}_{h}$ ) was calculated as follows:

in vivo $\mathrm{CL}_{\mathrm{h}}\left[\mathrm{ml} \mathrm{min}^{-1} \mathrm{~kg}^{-1}\right]=\frac{\mathrm{CL}^{\text {int }} \times(\mathrm{mg} \text { protein } / \mathrm{g} \text { liver }) \times \mathrm{Q} \times(\mathrm{LW} / \mathrm{BW})}{\left[\mathrm{Q}+\left(\mathrm{CL}^{\text {int }} \times(\mathrm{mg} \text { protein } / \mathrm{g} \text { liver }) \times(\mathrm{LW} / \mathrm{BW})\right)\right.}$

where:

$\mathrm{LW} / \mathrm{BW}=$ liver weight/body weight $\left[\mathrm{g} \mathrm{kg}^{-1}\right] ; 21$ (human), 87.5 (mouse)

$\mathrm{Q}=\mathrm{LBF}=$ liver blood flow $\left[\mathrm{ml} \mathrm{min} \mathrm{kg}^{-1}\right] ; 20$ (human), 90 (mouse)

Predicted in vivo hepatic clearance can be expressed as \%LBF and calculated as follows:

in vivo $\mathrm{CL}_{\mathrm{h}}[\% \mathrm{LBF}]=\frac{(\text { in vivo } \mathrm{CL})}{L B F} \times 100$

\section{Kinetic solubility assay}

The compound DMSO solutions were spiked into aqueous buffer (100 mM PBS) at final tested concentrations of 100, 30, 10, 3 and $1 \mu \mathrm{M}\left(1 \%\right.$ DMSO v/v), incubated at $37{ }^{\circ} \mathrm{C}$ for $2 \mathrm{~h}$ with gentle shaking and absorbance of suspension was measured at $620 \mathrm{~nm}$ (Tecan Infinite microplate reader). Sample compounds, tested in two replicas per concentration, were compared to a solvent control in aqueous buffer and solubility range calculations were made using Excel tools. Results were expressed as an estimated solubility range ( $\mu \mathrm{M}$, lower and upper bound). Assay was verified by simultaneous analysis of two standard compounds, $\alpha$-naphtoflavone and sulfaphenazole.

\section{Chromatographic Hydrophobicity Index (CHI)/ChromLogD determination}

The chromatographic hydrophobicity parameter (CHI) was determined by measuring compounds' gradient retention times by LC-DAD-MS (Agilent 1100 coupled with a mass spectrometer Micromass Quattro API). Compounds were prepared for analysis in final concentration of $1.25 \mathrm{mM}$. Experiments were run at $\mathrm{pH} 7.4$ with an acetonitrile gradient and ammonium acetate solution as the aqueous part of the mobile phase. CHI values were derived from the compounds' retention times and converted to the distribution coefficient (ChromLogD) values. 


\section{Plasma protein binding}

Plasma protein binding (PPB) measurements were done using equilibrium dialysis technique. The assay was performed in a 96-well Teflon dialysis unit, with wells being separated by a dialysis membrane in two chambers. Test and control compounds were prepared by diluting DMSO working solutions to $5 \mu \mathrm{M}(0.5 \%$ DMSO) in mouse (CD-1 mouse EDTA plasma, Seralab) or human (EDTA plasma, Seralab) plasma. Plasma spiked with compound is added to one chamber and isotonic phosphate buffer solution $\mathrm{pH} 7.4$ to the other side of the well. Each compound was analysed in duplicate and dialyzed for $4 \mathrm{~h}$ at $37{ }^{\circ} \mathrm{C}$. After dialysis was complete, both plasma and buffer were sampled from the Teflon cells, reaction was terminated by addition of a $\mathrm{MeCN} / \mathrm{MeOH}$ (2:1) mixture, containing internal standard and analyzed by LC-MS/MS. The fraction bound was calculated as the concentration difference in plasma and buffer sides divided by the total concentration in the plasma side. Controls used in this assay were acebutolol, verapamil and nicardipine.

\section{CYP3A4 isoform inhibition assay}

The potential for CYP3A4 inhibition was evaluated in human recombinant enzymes (Supersomes, BD Biosciences) using a single concentration of test compound and DBF (dibenzylfluorescein) and 7BQ (7-benzyloxyquinoline) as probe substrates. Inhibition was measured using a fluorescent readout (Tecan Infinite) and samples are compared to a solvent control to determine $\%$ inhibition at $10 \mu \mathrm{M}$. Ketoconazole was used as a control.

\section{Blood stability}

Fresh CD-1 mouse whole blood (collected in EDTA-containing tubes, generated from the in-house animal facility) and human blood (collected in Citrate Phosphate Dextrose Solution obtained from Croatian Institute for Transfusion Medicine) were used as a biological matrix. Test compounds or control compounds, prepared from the $10 \mathrm{mM}$ methanol stock solutions, at $1 \mu \mathrm{M}$ final concentration $\left(0.1 \%\right.$ methanol) were added to the tubes containing whole blood. Samples were incubated at $37{ }^{\circ} \mathrm{C}$ with gentle agitation. Aliquots were taken at $0,10,30$ and $60 \mathrm{~min}$, and reaction was terminated by addition of a MeCN/MeOH (2:1) mixture, containing internal standard. Aliquots were then centrifuged and resulting supernatants were subjected to LCMS/MS analysis under conditions stated at the end of this section. Controls used in this assay were benfluorex (mouse blood), eucatropine (human blood) and propranolol (human and mouse blood). Blood stability results were expressed as \% parent compound remaining.

\section{LC-MS/MS analysis}

Samples were quantified using tandem mass spectrometry coupled to liquid chromatography. Samples were analysed on a Sciex API4000 Triple Quadrupole Mass Spectrometer (Sciex, Division of MDS Inc., Toronto, Canada) coupled to a Shimadzu Nexera X2 frontend (Kyto, Japan). Samples were injected onto a UPLC column (Waters Acquity UPLC BEH 1.7 um, 2.1x50 mm or Phenomenex Kinetex 2.6u C18 100A, 30x2.1) and eluted with a gradient at 50 or $25^{\circ} \mathrm{C}$. The mobile phase was composed of acetonitrile/water mixture (9/1, with $0.1 \%$ formic acid) and $0.1 \%$ formic acid in deionized water. The flow rate was $0.7 \mathrm{~mL} / \mathrm{min}$ and under gradient conditions, leading to a total run time of 1.5-2 min. Positive ion mode with turbo spray, an ion source temperature of $550{ }^{\circ} \mathrm{C}$ and a dwell time of $150 \mathrm{~ms}$ were utilized for mass spectrometric detection. Quantitation was performed using multiple reaction monitoring (MRM) at the specific transitions for each compound.

\section{hERG fluorescence polarization assay}

To investigate binding of test compounds to the hERG $\mathrm{K}^{+}$channel, predictor fluorescence polarization assay (ThermoFisher Scientific, Cat\# PV5365) is used. It is a high-throughput surrogate for the hERG patch clamp electrophysiological assay. Data obtained in this assay correlate well to published $\mathrm{IC}_{50}$ values of known hERG channel blockers as determined by radioligand binding assays and patch-clamp recordings. ${ }^{14}$ Mother plates with serial dilutions of compounds in pure DMSO are prepared from 10 mM DMSO stock solutions. Storplate-384-deep-well-V plates (Perkin Elmer, 6008590) are used for mother plate preparation. Compounds are diluted in a ratio of 1:3. An aliquot of $100 \mathrm{nl}$ of compound solution was transferred from the mother plate to the test plate (Greiner low volume black, 784076) with a Mosquito liquid handling system (SPT Labtech). The assay is performed in triplicate using a $10 \mu \mathrm{l}$ assay volume. Calculation of IC $_{50}$ data, and QC analysis is made by using Excel (MS) and Prism (GraphPad, San Diego, US) software. 
All animal experiments were approved by Committee for Animal Research Ethics, Zagreb and follow institutional guidelines. Animals were housed under standard conditions in a facility with a $12 \mathrm{~h}$ day-night cycle and with free access to water and food (SDS VRF 1 (P), UK). Animals receiving treatment orally were fasted overnight and food was provided to them $4 \mathrm{~h}$ after treatment.

Male CD-1 mice (weighing approximately 30-35 g, Charles River, Italy) were administered compound 4 via oral gavage (P0), at 5 and $10 \mathrm{mg} / \mathrm{kg}$ and compound 56 at $10 \mathrm{mg} / \mathrm{kg}$ and with a volume of administration of $10 \mathrm{~mL} / \mathrm{kg}$.

Compounds were administered orally as suspension (compound 4) in methylcellulose (0.5 \%)/citric acid (0.1 M) (96.5/3.5, $\mathrm{v} / \mathrm{v}$ ) or as a solution (compound 49) in DMSO/PEG200/ $\mathrm{NaCl} 0.9 \%(5 / 30 / 65, \mathrm{v} / \mathrm{v})$. Compounds were also administered intravenously (IV) at $1 \mathrm{mg} / \mathrm{kg}$ with a volume of administration of $5 \mathrm{~mL} / \mathrm{kg}$, as solutions in phosphate buffered saline (PBS)/citric acid (0.1 M) (96.5/3.5, v/v) for compound 4 or in DMSO/PEG200/NaCl 0.9\% (5/30/65, v/v) for compound 49. Blood $(25 \mu \mathrm{l}$ ) was collected into K2EDTA-coated tubes by serial sampling (three mice were dosed per group) and transferred into polypropylene tubes containing $25 \mu \mathrm{l}$ of deionised water. Time points for blood samples were $0.5,1,3$ and $6 \mathrm{~h}$ for PO groups, and $0.083,0.25,0.5,1,3$ and $6 \mathrm{~h}$ for the IV groups.

\section{Sample preparation and bioanalysis}

Blood concentrations from the mouse studies were measured for compound 4 and compound 49 using research-qualified LCMS/MS methods. Protein precipitation was used for sample preparation. An aliquot of $25 \mu \mathrm{l}$ of mouse blood was mixed with same volume of water and then protein precipitated with $300 \mu \mathrm{l}$ of protein precipitation solution (acetonitrile/methanol, $2 / 1$, $\mathrm{v} / \mathrm{v}$, containing $100 \mathrm{ng} / \mathrm{ml}$ of diclofenac as internal standard). Thereafter, the mixture was vortex mixed for $10 \mathrm{~s}$ and centrifuged for $30 \mathrm{~min}$ at $4500 \mathrm{rpm}$ and $4{ }^{\circ} \mathrm{C}$. Clear supernatant was mixed with water in LC-MS plate and analyzed for drug concentrations against matrix matched calibration standard curve (a minimum of 6-point) by liquid chromatography with tandem mass spectrometry (LC-MS/MS). 


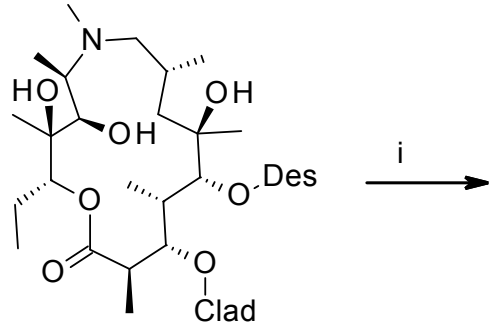

A

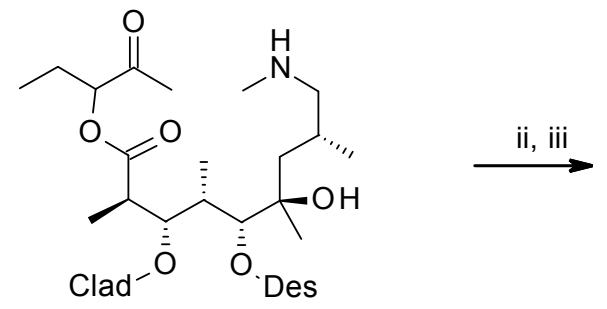

B

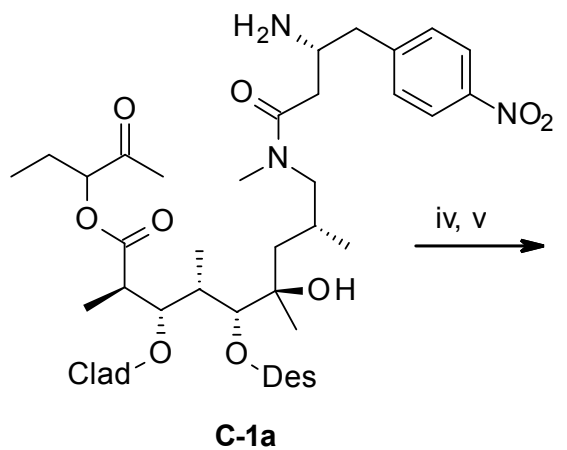<smiles>CC(CN(C)C(=O)C[C@@H](Cc1ccc([N+](=O)[O-])cc1)NC(=O)C(N)C(C)C)CC(C)(O)[C@H](OC(C)C)[C@H](C)[C@H](OC(C)C)C(C)C(=O)O</smiles>

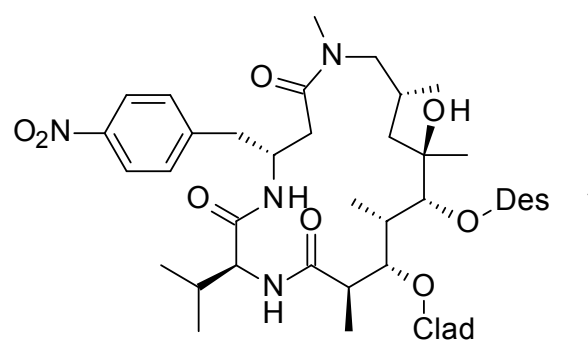

D-1

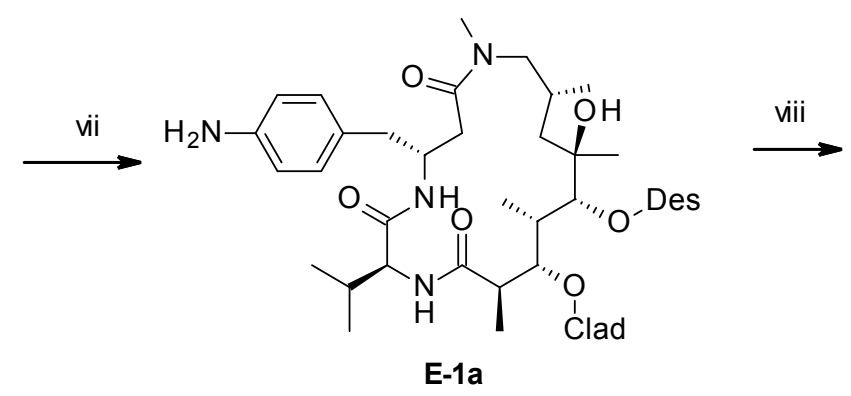

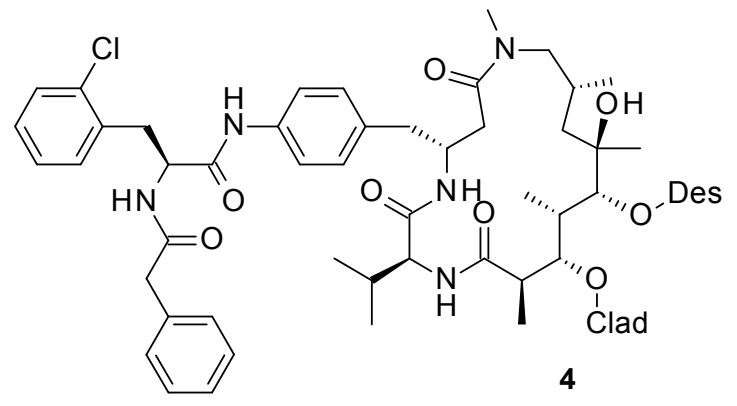

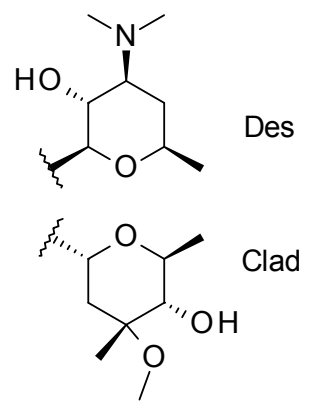

Reagents and conditions: (i) $\mathrm{Pb}(\mathrm{OAc})_{4}, \mathrm{AcOH}$; (ii) Fmoc-(R)-3-amino-4-(4-ntrophenyl)-butiric acid; HATU, HOAt, TMP, DCM, r.t. (iii) piperidine, DCM, r.t. (iv) Fmoc-L-Valine, HATU, HOAt, TMP, DCM, r.t. (v) LiOH, THF/water, r.t. (v) HATU, DIPEA, DMF, r.t. (vii) Pd/C; hydrogen; MeOH; r.t. (viii) 64, HATU, DIPEA, DMF,

\section{Scheme S1. Synthesis of the lead compound 4}


Intermediate E-1a was used for the preparation of compounds 28-64 (Scheme S2). In some cases (compounds $\mathbf{3 4}$ and $\mathbf{4 0}$ ) the side chains were introduced on a similar way from preformed dipeptides (65 and 66), while in most cases synthesis included two subsequent sets of amidation/deprotection reactions (28-45 and 56-64). Ureas 48-55 and sulfonamide 47 were smartly prepared from intermediate $\mathbf{E - 1 b}$ using an appropriate isocyanate or sulfonylchloride, respectively.

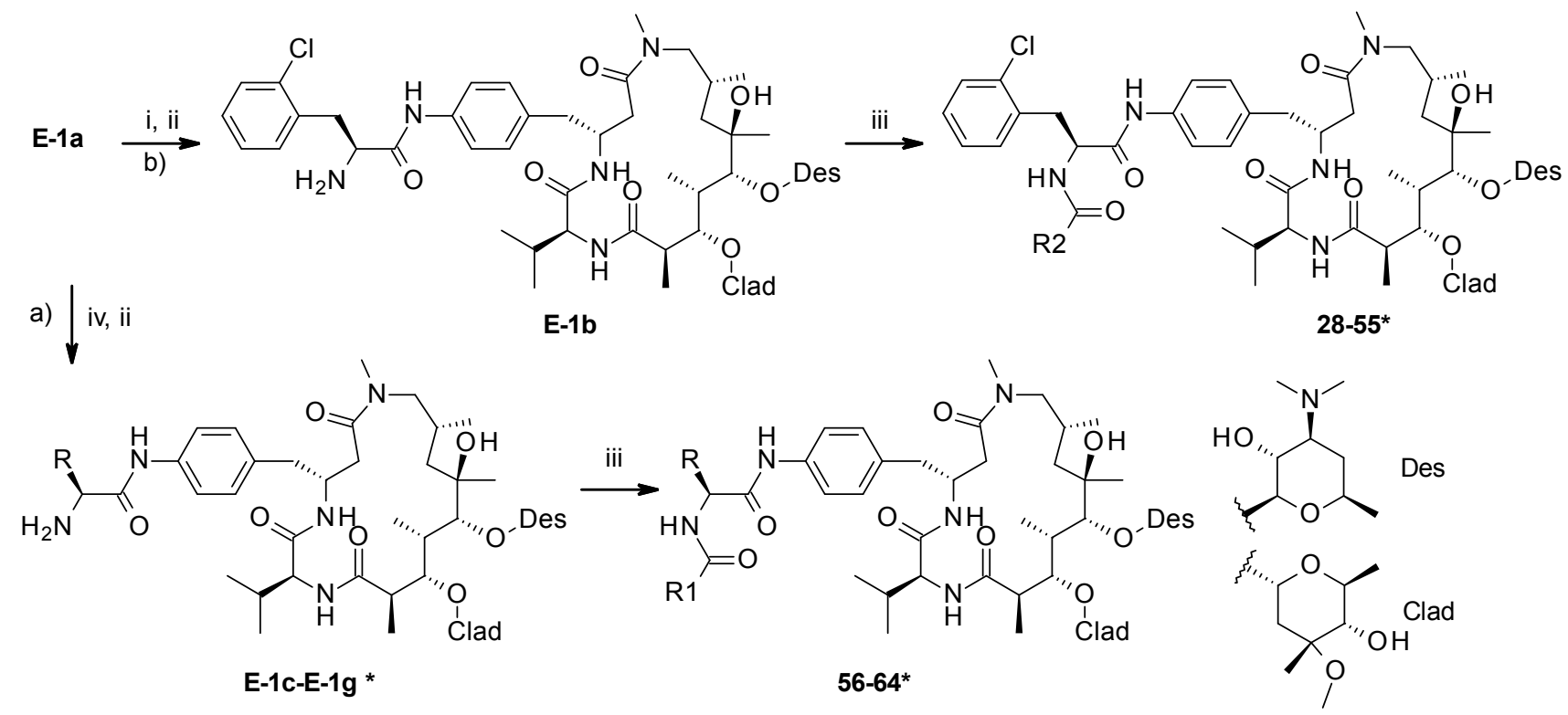

aReagents and conditions: path b (i) Fmoc-2-chloro-L-phenylalanine, HATU, DIPEA, DMF, r.t. (ii) piperidine, DCM, r.t. (iii) amidation: corresponding acid, HATU, DIPEA, DMF, r.t.; urea formation: corresponding isocyanate, DCM, r.t.; sulfonamide formation: corresponding sulfonyl chloride, TEA., DCM, r.t.; path a (iv) corresponding Fmoc protected amino acid HATU, DIPEA, DMF, r.t.; *) for R, R1 and R2 see Tables 2c and d. See the Experimental Section and Supporting Information for further details.

\section{Scheme S2. Synthesis of compounds 28-64}

\section{Synthesis of intermediates}
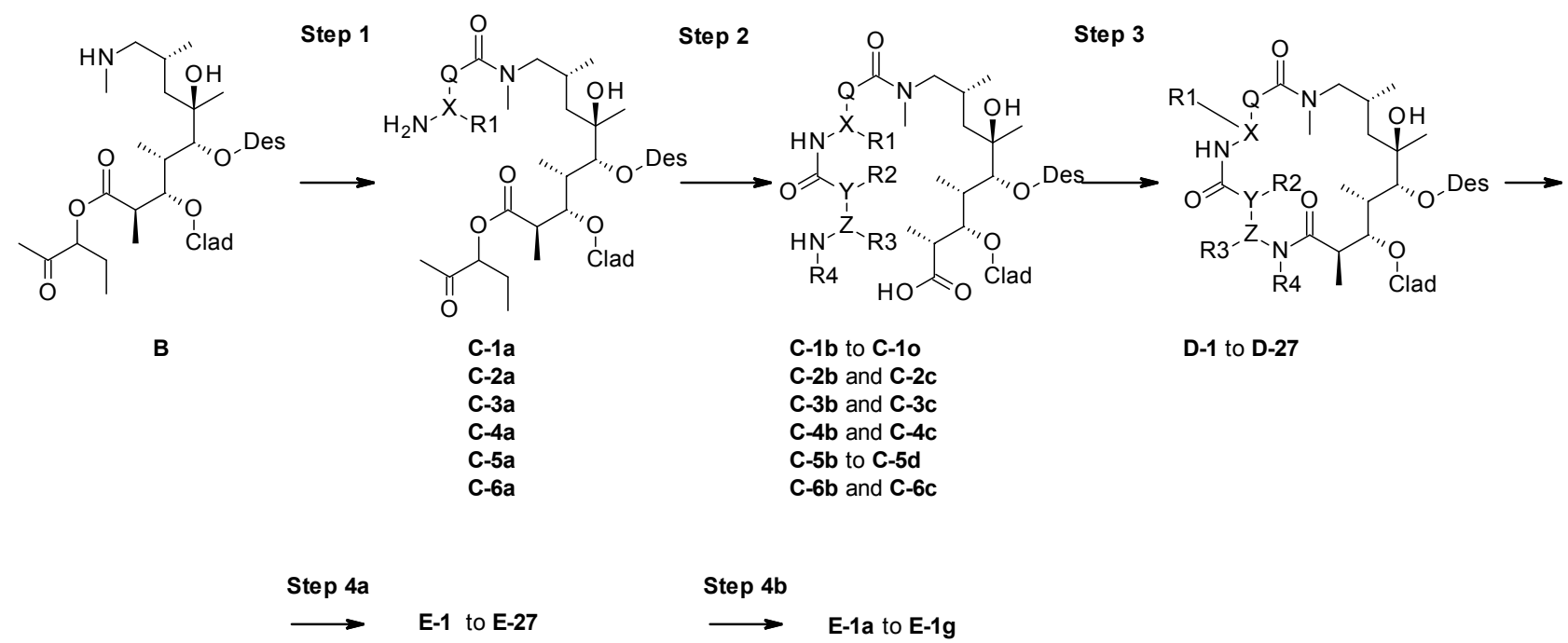

Scheme S3. Preparation of compounds 1-27, 34, 38 and 40 (analogy to synthesis of compound 4) 


\section{General procedures}

\section{Ring opening}<smiles>CCC(OC(=O)C(C)[C@H](O[Ge])[C@@H](C)[C@H](O[R6](=O)O[Na])C(C)(O)C[C@H](C)CNC)C(C)=O</smiles>

Synthesis of [(1R)-1-ethyl-2-oxo-propyl] $\quad(2 \mathrm{R}, 3 \mathrm{~S}, 4 \mathrm{~S}, 5 \mathrm{R}, 6 \mathrm{R}, 8 \mathrm{R})-5-[(2 \mathrm{~S}, 3 \mathrm{R}, 4 \mathrm{~S}, 6 \mathrm{R})-4$ (dimethylamino)-3-hydroxy-6-methyl-tetrahydropyran-2-yl]oxy-6-hydroxy-3-[(2R,4R,5S,6S)5-hydroxy-4-methoxy-4,6-dimethyl-tetrahydropyran-2-yl]oxy-2,4,6,8-tetramethyl-9(methylamino)nonanoate (B)

To a solution of A (Azitromycin, CAS 83905-01-5, 20 g, $26.7 \mathrm{mmol}$ ) in acetic acid (glacial, 150 $\mathrm{mL}$ ) lead (IV) acetate $23.7 \mathrm{~g}, 53.45 \mathrm{mmol}$ ) was added and reaction mixture stirred at room temperature for 1.5 hours. Solvent was evaporated and residue dissolved in DCM (100 mL) and water $(40 \mathrm{~mL}) . \mathrm{pH}$ of water layer is adjusted to $6.8(40 \% \mathrm{NaOH})$, layers separated and organic layer washed with water. Combined water layers were basified to $\mathrm{pH} 8(40 \% \mathrm{NaOH})$ and extracted with diethylether (3 x $100 \mathrm{~mL})$ and then with DCM/isopropanol ( $3 \times 150 \mathrm{~mL})$. Combined DCM layers were dried over anh. Na2SO4 and solvent evaporated. Crude product was purified by column chromatography (silica gel, eluent DCM:MeOH:NH4OH = 90:15:1.5) to yield of title product (14.1 g, yield $76 \%$, purity $79 \%$ ). ES+ m/z $691.6[\mathrm{MH}]+$.

\section{Step 1-Introduction of the first amino acid (synthesis of intermediates C-1a to C-6a)}

To a solution of appropriate Fmoc-protected aminoacid (1.1 eq) in dry DCM, TMP (2.5 eq), HOAt (1.1 eq) and HATU (1.1 eq) were added. After stirring for $1 \mathrm{~h}$ at room temperature amine $\mathbf{B}(1 \mathrm{eq})$ was added and stirring was continued overnight. The reaction mixture was washed with sat. $\mathrm{NaHCO}_{3}$ and brine. The organic layer was dried over $\mathrm{Na}_{2} \mathrm{SO}_{4}$. Solvent was removed under reduced pressure and the crude product. Crude product was dissolved in dry DCM and piperidine (5 eq) was added and the resulting mixture was stirred at room temperature overnight. The reaction mixture was concentrated under reduced pressure and purified by flash column chromatography DCM:MeOH: $\mathrm{NH}_{4} \mathrm{OH}=90: 9: 1.5$ as an eluent to give $\mathbf{C - 1 a - C - 6 a}$.

Table S7. Intermediates synthesized in Step 1

\begin{tabular}{|c|c|c|c|c|c|c|}
\hline INT & $\mathbf{Q}$ & $\mathbf{X}$ & R1 & Starts from & Yield (\%) & {$[\mathrm{M}+\mathrm{H}]^{+}(\mathrm{m} / \mathrm{z})$} \\
\hline C-1a & $\mathrm{CH}_{2}$ & $\mathrm{CH}(R)$ & & $\begin{array}{l}\text { Fmoc- }(R) \text { p- } \mathrm{NO}_{2}-\beta-P h e(4 \mathrm{~g}) \\
\text { B-1 (5.6 g) }\end{array}$ & 81 & 897.57 \\
\hline C-2a & $\mathrm{CH}_{2}$ & $\mathrm{CH}(S)$ & & $\begin{array}{l}\text { Fmoc- }(S) \text { p- } \mathrm{NO}_{2}-\beta-P h e(4 \mathrm{~g}) \\
\text { B-1 }(5.63 \mathrm{~g})\end{array}$ & 95 & 897.6 \\
\hline C-3a & - & $\mathrm{CH}(R)$ & & $\begin{array}{l}\text { Fmoc- }(R)-\alpha \text {-Val }(1.08 \mathrm{~g}) \\
\text { B-1 }(2 \mathrm{~g})\end{array}$ & crude & 790.6 \\
\hline$C-4 a$ & - & $\mathrm{CH}(S)$ & & $\begin{array}{l}\text { Fmoc- }(S)-\alpha-\operatorname{Val}(1.08 \mathrm{~g}) \\
\text { B-1 }(2 \mathrm{~g})\end{array}$ & crude & 790.5 \\
\hline C-5a & - & $\mathrm{CH}(R)$ & & $\begin{array}{l}\text { Fmoc- }(R) \text { p- } \mathrm{NO}_{2}-\alpha-\text { Phe }(2.2 \mathrm{~g}) \\
\text { B-1 }(4 \mathrm{~g})\end{array}$ & 35 & 883.5 \\
\hline$C-6 a$ & - & $\mathrm{CH}(S)$ & & $\begin{array}{l}\text { Fmoc- }(S) \text { p- } \mathrm{NO}_{2}-\alpha \text {-Phe }(2.2 \mathrm{~g}) \\
\text { B-1 }(4 \mathrm{~g})\end{array}$ & 39 & 883.5 \\
\hline
\end{tabular}




\section{Step 2 -Introduction of the second amino acid moiety (Scheme S3)}

To a solution of appropriate Fmoc-protected aminoacid (1.1 eq) in dry DCM, TMP (2.5 eq), HOAt (1.1 eq) and HATU (1.1 eq) were added. After stirring for $1 \mathrm{~h}$ at room temperature intermediate $\mathbf{C - 1 a}(1 \mathrm{eq})$ was added and stirring continued at room temperature for $20 \mathrm{~h}$. The reaction mixture was washed with sat. $\mathrm{NaHCO}_{3}$ and brine. The organic layer was dried over $\mathrm{Na}_{2} \mathrm{SO}_{4}$. Solvent was removed under reduced pressure. Crude product was dissolved in THF and water solution of LiOH (5 eq) was added dropwise and the resulting mixture was stirred at room temperature overnight. Solvent was evaporated, residue dissolved in water and extracted with DCM. pH of water layer was adjusted at pH 4 and extracted with DCM. After extraction in acidic media $\mathrm{pH}$ of water layer is adjusted at $\mathrm{pH} 10$ and extracted with DCM/i-PrOH (2:1). Combined organic layers (obtained by extraction at $\mathrm{pH} 10$ ) were dried over $\mathrm{Na}_{2} \mathrm{SO}_{4}$ and solvent evaporated under reduced pressure to yield the desired intermediate.

Table S8. Intermediates synthesized in Step 2

\begin{tabular}{|c|c|c|c|}
\hline INT & Starts from & Yield (\%) & {$[\mathrm{M}+\mathrm{H}]^{+}(\mathrm{m} / \mathrm{z})$} \\
\hline C-1b & $\begin{array}{l}\text { Fmoc- }(S) \alpha \text {-Val }(333 \mathrm{mg}) \\
\text { C-1a }(800 \mathrm{mg})\end{array}$ & 75 & 912.6 \\
\hline$C-1 c$ & $\begin{array}{l}(1 R, 2 R) \text {-Fmoc-2-aminocyclopentane carboxylic acid (200 mg) } \\
\text { C-1a (500 mg) }\end{array}$ & 27 & 924.9 \\
\hline$C-1 d$ & $\begin{array}{l}\text { Fmoc-2-[1-(aminomethyl) cyclopentyl]acetic acid (372 mg) } \\
\text { C-1a (800 mg) }\end{array}$ & 84 & 952.7 \\
\hline C-1e & $\begin{array}{l}\text { Fmoc- }(S) \text { proline }(206 \mathrm{mg}) \\
\text { C-1a }(500 \mathrm{mg})\end{array}$ & Crude & 910.5 \\
\hline C-1f & $\begin{array}{l}\text { Fmoc- }(R) \alpha \text {-Val (333 mg) } \\
\text { C-1a ( } 800 \mathrm{mg})\end{array}$ & 82 & 912.6 \\
\hline C-1g & $\begin{array}{l}\text { Fmoc- }(S)-\alpha \text {-Ala }(250 \mathrm{mg}) \\
\text { C-1a }(682 \mathrm{mg})\end{array}$ & 93 & 884.6 \\
\hline C-1h & $\begin{array}{l}\text { Fmoc- }(R)-\alpha-\text { Ala }(236 \mathrm{mg}) \\
\text { C-1a }(680 \mathrm{mg})\end{array}$ & 94 & 884.7 \\
\hline C-1i & $\begin{array}{l}\text { Fmoc- }(S)-\alpha-\mathrm{t}-\mathrm{Bu}-\mathrm{Gly}(295 \mathrm{mg}) \\
\text { C-1a }(680 \mathrm{mg})\end{array}$ & 60 & 926.6 \\
\hline$C-1 j$ & $\begin{array}{l}\text { Fmoc- }(S)-\alpha \text {-Cyp-Gly }(281 \mathrm{mg}) \\
\text { C-1a }(680 \mathrm{mg})\end{array}$ & 98 & 910.8 \\
\hline$C-2 b$ & $\begin{array}{l}\text { Fmoc- }(S) \alpha \text {-Val }(1.65 \mathrm{~g}) \\
\text { C-2a }(3.96 \mathrm{~g})\end{array}$ & 59 & 912.5 \\
\hline$C-3 b$ & $\begin{array}{l}\text { Fmoc- }(S) \text { p-NO }{ }_{2}-\beta-\text { Phe }(530 \mathrm{mg}) \\
\text { C-3a }(850 \mathrm{mg})\end{array}$ & Crude & 912.6 \\
\hline$C-3 c$ & $\begin{array}{l}\text { Fmoc- }(R) \text { p- } \mathrm{NO}_{2}-\beta \text {-Phe }(530 \mathrm{mg}) \\
\text { C-3a }(850 \mathrm{mg})\end{array}$ & Crude & 912.5 \\
\hline$C-4 b$ & $\begin{array}{l}\text { Fmoc- }(S) \text { p- } \mathrm{NO}_{2}-\beta-\text { Phe }(466 \mathrm{mg}) \\
\text { C-4a }(750 \mathrm{mg})\end{array}$ & crude & 912.5 \\
\hline$C-4 c$ & $\begin{array}{l}\text { Fmoc- }(R) \text { p- } \mathrm{NO}_{2}-\beta-\text { Phe }(466 \mathrm{mg}) \\
\text { C-4a }(750 \mathrm{mg})\end{array}$ & Crude & 912.5 \\
\hline$C-5 b$ & $\begin{array}{l}\text { Fmoc- }(S) \text {-Homo- } \beta \text {-Val }(289 \mathrm{mg}) \\
\text { C-5a }(812 \mathrm{mg})\end{array}$ & 77 & 912.6 \\
\hline$C-5 c$ & $\begin{array}{l}\text { Fmoc- }(R) \text {-Homo- } \beta \text {-Val }(310 \mathrm{mg}) \\
\text { C-5a (700 mg) }\end{array}$ & 87 & 912.5 \\
\hline$C-5 d$ & $\begin{array}{l}\text { Fmoc- }(S)-\beta \text {-homoVal }(310 \mathrm{mg}) \\
\text { C-5a (700 mg) }\end{array}$ & 77 & 912.6 \\
\hline C-5e & $\begin{array}{l}\text { Fmoc- }(S)-\alpha-\operatorname{Val}(223 \mathrm{mg}) \\
\text { C-5a }(580 \mathrm{mg})\end{array}$ & Crude & 898.8 \\
\hline$C-6 b$ & $\begin{array}{l}\text { Fmoc- }(S)-\alpha-\text { Val }(690.2 \mathrm{mg}) \\
\text { C-6a }(1.60 \mathrm{~g})\end{array}$ & 89 & 898.4 \\
\hline$C-1 k$ & $\begin{array}{l}\text { Fmoc- }(R) \text {-Homo- } \beta \text {-Val }(250 \mathrm{mg}) \\
\text { C-1a }(630 \mathrm{mg})\end{array}$ & 93 & 926.7 \\
\hline C-11 & $\begin{array}{l}\text { Fmoc- }(S)-\beta \text {-homoVal (163 mg) } \\
\text { C-1a (386 mg) }\end{array}$ & 87 & 926.7 \\
\hline C-1m & $\begin{array}{l}\text { Fmoc- }(R)-\beta \text {-homoVal (303 mg) } \\
\text { C-1a (700 mg) }\end{array}$ & 86 & 926.5 \\
\hline$C-1 n$ & $\begin{array}{l}\text { Fmoc- }(R) \text {-Homo- } \beta \text {-Leu }(261 \mathrm{mg}) \\
\text { C-1a }(630 \mathrm{mg})\end{array}$ & 46 & 940.8 \\
\hline C-1o & $\begin{array}{l}\text { Fmoc-Homo-Gly (243 mg) } \\
\text { C-1a (700 mg) }\end{array}$ & 94 & 884.7 \\
\hline
\end{tabular}


Step 3 - Macrocyclisation (synthesis of intermediates D-1-D-21, Scheme S3)

DMF solution of appropriate intermediate from table S7 (1 eq, 60-150 mM) and DIPEA (2 eq) was added (dropwise over 30$60 \mathrm{~min}$ ) to a DMF (anhydrous) solution of HATU (1.5 eq, 100-120 mM) and the reaction mixture was stirred at room temperature for additional $1 \mathrm{~h}$. EtOAc was added, and the organic layer was washed with sat. $\mathrm{NaHCO}_{3}$ and brine. The organic layer was dried over $\mathrm{Na}_{2} \mathrm{SO}_{4}$ and concentrated under reduced pressure yielding a crude material which was purified by flash column chromatography with DCM:MeOH: $\mathrm{NH}_{4} \mathrm{OH}=$ 90:9:0.5 as an eluent to give intermediates D-1-D-21.

Table S9. Intermediates synthesized in Step 3

\begin{tabular}{|c|c|c|c|c|c|c|c|}
\hline INT & Starts from & Yield (\%) & {$[\mathrm{M}+\mathrm{H}]^{+}(\mathrm{m} / \mathrm{z})$} & INT & Starts from & Yield (\%) & {$[\mathrm{M}+\mathrm{H}]^{+}(\mathrm{m} / \mathrm{z})$} \\
\hline D-1 & C-1b (740 mg) & 27 & 894.6 & D-15 & C-3c (1.16 g) & 37 & 894.5 \\
\hline D-2 & C-1c (140 mg) & crude & 907.0 & D-16 & C-4b (970 mg) & crude & 894.6 \\
\hline D-3 & C-1d (718 mg) & 55 & 934.7 & D-17 & C-4c (980 mg) & 60 & 894.5 \\
\hline D-4 & $\mathbf{C}-\mathbf{1 e}(440 \mathrm{mg})$ & 35 & 892.9 & D-18 & C-5b (462 mg) & 76 & 894.5 \\
\hline D-5 & $\mathbf{C - 1 f}(670 \mathrm{mg})$ & 32 & 894.6 & D-19 & C-5c (770 mg) & 27 & 894.5 \\
\hline D-6 & $\mathbf{C}-2 \mathbf{b}(1 \mathrm{~g})$ & 59 & 894.6 & D-20 & C-5d (560 mg) & 18 & 894.5 \\
\hline D-7 & C-7b (1.9 g) & 8 & 894.6 & D-21 & C-5e (660 mg) & 31 & 880.7 \\
\hline D-8 & C-1g (630 mg) & 14 & 866.7 & D-22 & C-6b (1.61 g) & 19 & 880.5 \\
\hline D-9 & C-1h (441 mg) & 11 & 866.8 & D-23 & C-1k (603 mg) & 58 & 908.7 \\
\hline D-10 & C-8b (450 mg) & crude & 908.7 & D-24 & C-1l (346 mg) & 55 & 908.5 \\
\hline D-11 & C-9b (450 mg) & crude & 908.7 & D-25 & C-1m (570 mg) & 65 & 908.6 \\
\hline D-12 & C-1i (597 mg) & 17 & 908.6 & D-26 & C-1n (300 mg) & 90 & 922.7 \\
\hline D-13 & $\mathbf{C - 1 j}(706 \mathrm{mg})$ & 13 & 892.8 & D-27 & C-1o (654 mg) & 32 & 866.7 \\
\hline D-14 & C-3b (1.04 g) & 12 & 894.5 & & & & \\
\hline
\end{tabular}

\section{Alternative procedures for the preparation of Intermediates D-7, D-10 and D-11}

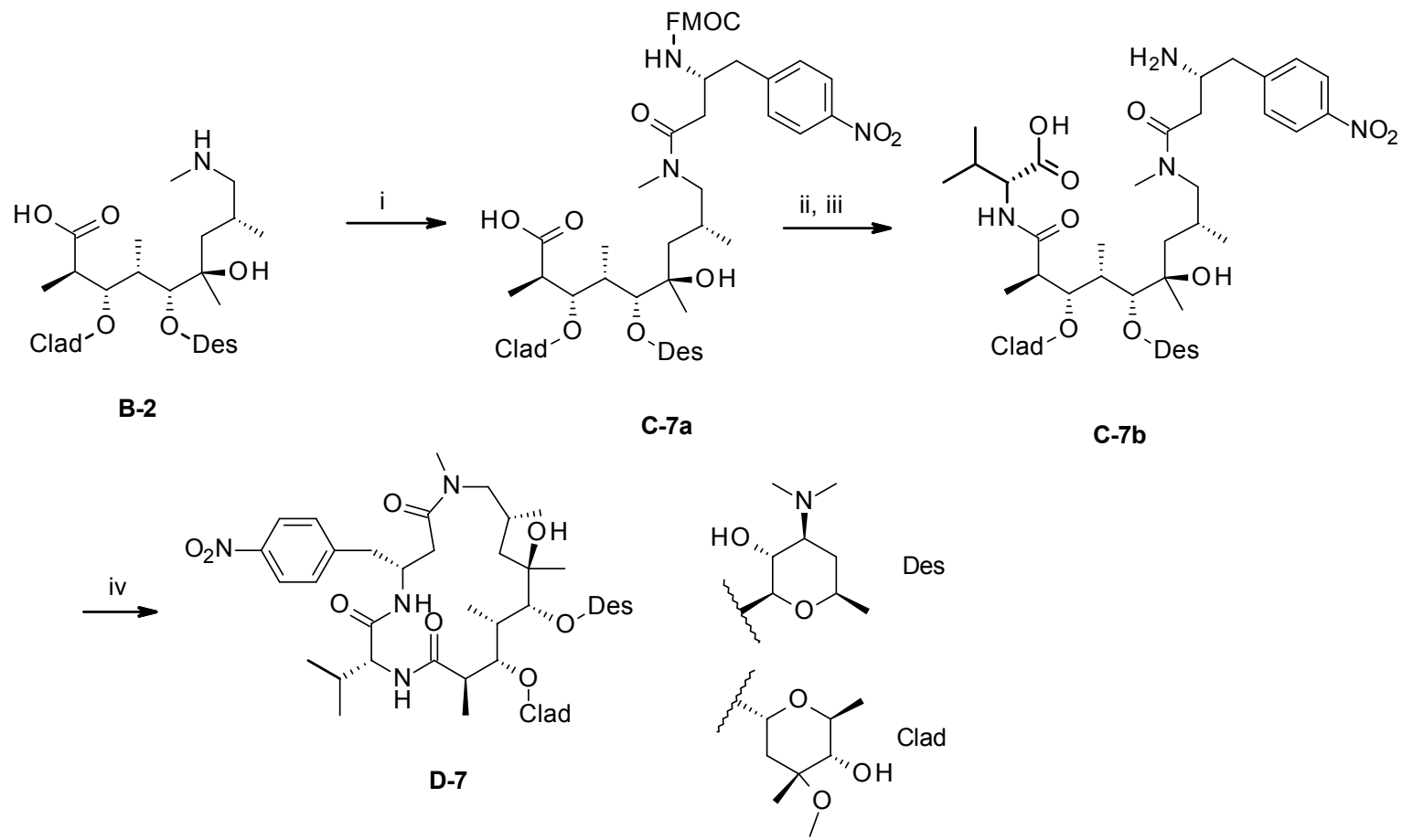

Reagents and conditions: (i) Fmoc-(S)-3-amino-4-(4-ntrophenyl)-butiric acid; HATU, HOAt, TMP, DCM, r.t.

(ii) (R)-Valine OMe. $\mathrm{HCl}$, HATU, HOAt, TMP, DCM, r.t. (iii) LiOH, THF/water, r.t. (iv) HATU, DIPEA, DMF, r.t.

\section{Scheme S4. Preparation of intermediate D-7}




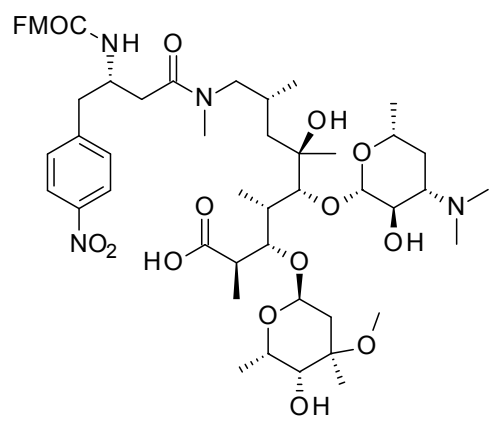

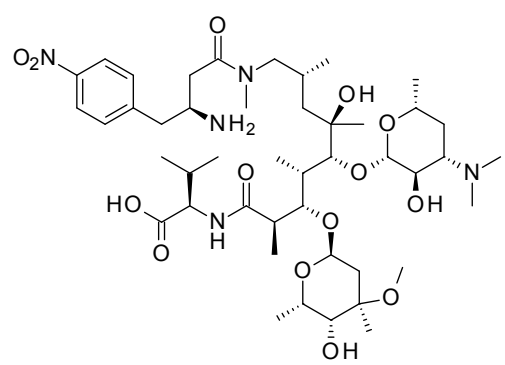

$((2 R, 3 S, 4 S, 5 R, 6 R, 8 R)-5(\beta-D-d e s o s a m i n y l) o x y-9-[[(3 S)-3-F m o c-a m i n o-4-(4-$ nitrophenyl)butanoyl]-methyl-amino]-6-hydroxy-3( $\alpha$-L-cladinosyl)oxy-2,4,6,8tetramethyl-nonanoic acid (C-7a)

To a solution of Fmoc- $(S)-3$-amino-4-(4-nitrophenyl)-butyric acid (1.57 g, $3.52 \mathrm{mmol})$ in DCM (50 mL). TMP (1.13 mL, $8 \mathrm{mmol})$ in dry DCM, TMP (0.94 mL, $5.24 \mathrm{mmol}$ ), HOAt (480 $\mathrm{mg}, 3.52 \mathrm{mmol}$ ) and HATU (1.34 g, $3.52 \mathrm{mmol}$ ) and were added and reaction mixture was stirred at room temperature for $30 \mathrm{~min}$. Solution of B-2 (2 g, $3.2 \mathrm{mmol})$ in DCM ( $5 \mathrm{~mL}$ ) was added to the reaction mixture and stirring proceeded overnight. Reaction was quenched with sat. aq. $\mathrm{NaHCO}_{3}$. Layers were separated and organics were dried over $\mathrm{K}_{2} \mathrm{CO}_{3}$. Solvent was removed under reduced pressure and crude product thus obtained (3.06 g) was used in the next synthetic step without further purification. $\mathrm{ES}+\mathrm{m} / \mathrm{z} 1035.6[\mathrm{M}+\mathrm{H}]^{+}$.

$(2 R)-2-[[(2 R, 3 S, 4 S, 5 R, 6 R, 8 R)-9-[[(3 S)-3$-amino-4-(4-nitrophenyl)butanoyl]-methylamino]-5( $\beta$-D-desosaminyl)oxy-6-hydroxy-3( $\alpha$-L-cladinosyl)oxy-2,4,6,8tetramethyl-nonanoyl]amino]-3-methyl-butanoic acid (C-7b)

To a solution of (C-7a) (1.5 g, $1.45 \mathrm{mmol})$ in dry DMF (15 mL) $(S)$-valine methyl ester. hydrochloride ( $268 \mathrm{~g}, 1.6 \mathrm{mmol})$ DIPEA $(0.63 \mathrm{~mL}, 3.62 \mathrm{mmol})$ and HATU $(827 \mathrm{mg}, 2.18$ mmol) were added. Reaction mixture was stirred at room temperature overnight. The reaction mixture was extracted with sat. aq. $\mathrm{NaHCO}_{3}$ and EtOAc. Combined organics were dried over $\mathrm{K}_{2} \mathrm{CO}_{3}$, filtered and concentrated under reduced pressure. The residue was dissolved in THF (20 mL) and solution of $\mathrm{LiOH}_{\mathrm{H}} \mathrm{H}_{2} \mathrm{O}$ in water was added. The reaction mixture was stirred at room temperature overnight. Organic solvent was removed under reduced pressure. Water was added and extraction with DCM:i-PrOH (1:1) was performed. Combined organics were dried over $\mathrm{Na}_{2} \mathrm{SO}_{4}$, filtered and solvent removed under reduced pressure. The crude product thus obtained (1.88 g) was used in the next synthetic step without further purification. ES+ m/z 912.6 [M+H] $]^{+}$.

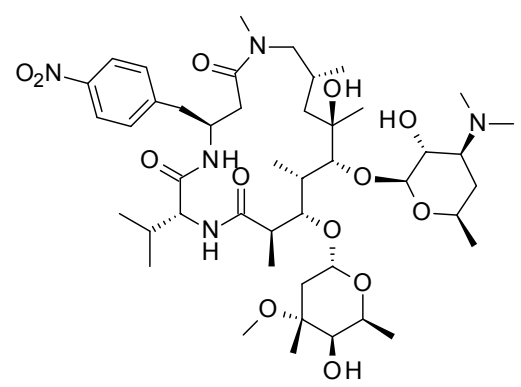

$(2 R, 5 S, 10 R, 12 R, 13 R, 14 S, 15 S, 16 R)-5-[(4$-nitroophenyl)methyl $]-13(\beta-\mathrm{D}-$ desosaminyl)oxy-12-hydroxy-15( $\alpha$-L-cladinosyl)oxy-2-isopropyl-8,10,12,14,16pentamethyl-1,4,8-triazacycloheptadecane-3,7,17-trione (D-7)

A solution of $\mathbf{C}-7 \mathbf{b}(1.9 \mathrm{~g}, 0.2 .1 \mathrm{mmol})$ in dry DMF $(10 \mathrm{~mL})$ was added dropwise to a stirred solution of HATU (1.2 g, $3.15 \mathrm{mmol}$ ), DIPEA (0.55 mL, $3.15 \mathrm{mmol}$ ) in DMF (25 $\mathrm{mL}$ ) and reaction mixture was stirred at room temperature for $15 \mathrm{~min}$ more. Extraction with sat. aq. $\mathrm{NaHCO}_{3}$ and EtOAc was performed. Combined organics were well washed with brine, dried over $\mathrm{Na}_{2} \mathrm{SO}_{4}$ and evaporated to dryness. Crude product was purified by SPE on SiO2 (10 g) and eluted with mixtures of DCM:methanolic ammonia. Title product was obtained as white foam (155 mg, 8 \%). ES+ m/z 894.6 $[\mathrm{M}+\mathrm{H}]^{+}$. 


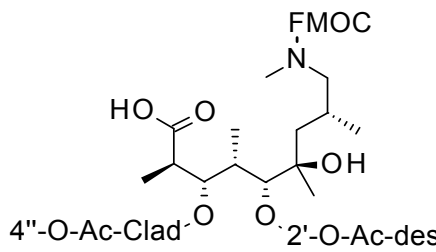

B-3

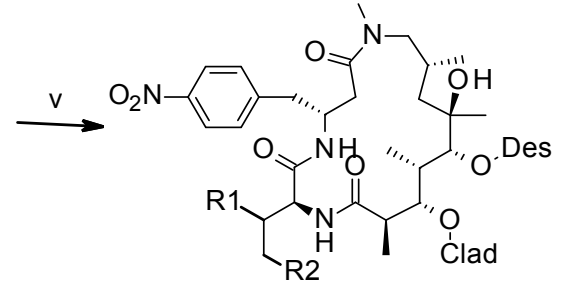

D-10 and D-11

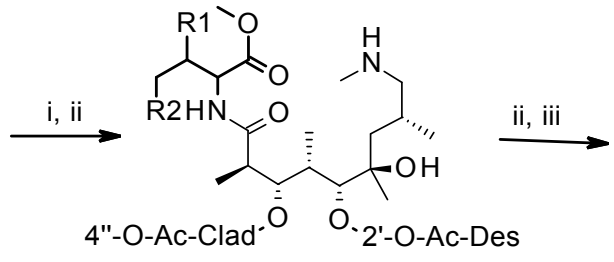

C-8a

C-9a

2'-O-Ac-Des<smiles>CC(C)[C@@H]1O[C@H](C)C[C@@H](N(C)C)[C@@H]1O</smiles>

4"-O-Ac-Clad<smiles>CC(C)[C@@H]1CC(C)(O)[C@H](O[C+](C)(C)C)O[C@@H]1C</smiles>

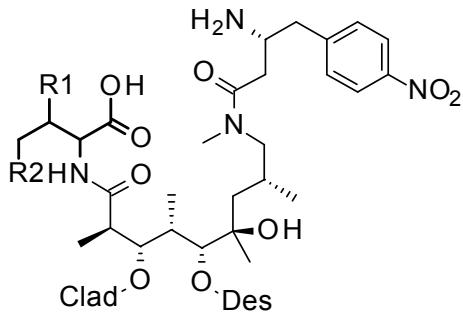

C-8b

C-9b

Reagents and conditions: (i) (S)-Leu OMe.HCl (for C-8a), or (S)-lle OMe.HCl (for C-9a), HATU, HOAt, TMP, DCM, r.t. (ii) piperidine, DMF, r.t. (iii) Fmoc-(R)-3-amino-4-(4-ntrophenyl)-butiric acid; HATU, HOAt, TMP, DCM, r.t. (iv) LiOH, THF/water, r.t. (v) HATU, DIPEA, DMF, r.t.

\section{Scheme S5. Synthesis of intermediates D-10 and D-11}

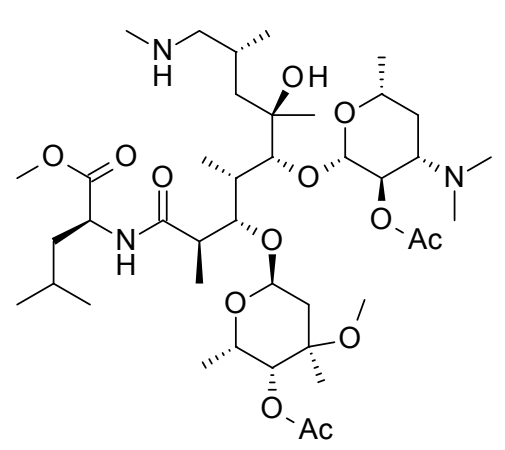

Methyl (2S)-2-[[(2R,3S,4S,5R,6R,8R)-5-(( $\beta$-D-2-0-acetyl-desosaminyl)oxy-3-( $\alpha$-L-4-0acetyl-cladinosyl)oxy-6-hydroxy-2,4,6,8-tetramethyl-9-(methylamino)nonanoyl] amino]-4-methyl-pentanoate (C-8a)

To a solution of B-3 (1.3 g, $1.42 \mathrm{mmol})$ in dry DCM, TMP (0.94 mL, $5.24 \mathrm{mmol})$, HATU (540 mg, $1.42 \mathrm{mmol}$ ) and HOAt (190 mg, $1.42 \mathrm{mmol}$ ) were added and reaction mixture was stirred at room temperature for $30 \mathrm{~min}$. L-leucine methyl ester $\mathrm{HCl}$ salt $(260 \mathrm{mg}$, $1.43 \mathrm{mmol}$ ) was added to the reaction mixture and stirring proceeded overnight. Reaction was quenched with sat. aq. $\mathrm{NaHCO}_{3}$. Layers were separated and aqueous one was extracted with DCM. Combined organics were dried over $\mathrm{K}_{2} \mathrm{CO}_{3}$. Solvent was removed under reduced pressure and crude product thus obtained was dissolved in DMF (30 mL). Piperidine ( $0.35 \mathrm{~mL} ; 3.54 \mathrm{mmol}$ ) was added. Reaction mixture was stirred at room temperature overnight. It was separated between sat. aq. $\mathrm{NaHCO}_{3}$ and EtOAc. Combined organics were washed with brine, dried over $\mathrm{K}_{2} \mathrm{CO}_{3}$, filtered and solvent removed under reduced pressure. The crude product $(1.26 \mathrm{~g})$ thus obtained was used in the next synthetic step without further purification. ES+ $\mathrm{m} / \mathrm{z} 818.7$ $[\mathrm{M}+\mathrm{H}]^{+}$.

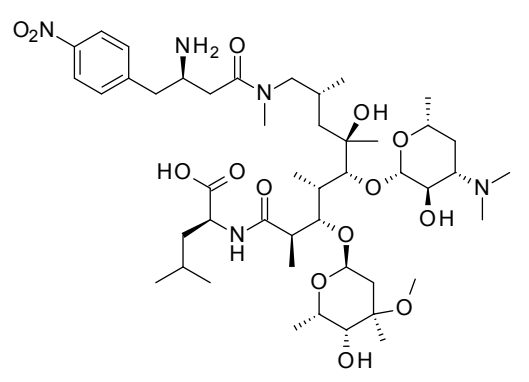

(2S)-2-[[(2R,3S,4S,5R,6R,8R)-9-[[(3R)-3-amino-4-(4-nitrophenyl)butanoyl]-methylamino]-5( $\beta$-D-desosaminyl)oxy-6-hydroxy-3( $\alpha$-L-cladinosyl)oxy-2,4,6,8-

tetramethyl-nonanoyl]amino]-4-methyl-pentanoic acid (C-8b)

To a solution of Fmoc- $(R)$-3-amino-4nitro-phenyl)-butyric acid (790 g, $1.55 \mathrm{mmol})$ in dry DCM (20 mL) TMP (0.65 mL, $3.85 \mathrm{mmol})$, HATU (700 mg, $1.84 \mathrm{mmol})$ and HOAt $(250 \mathrm{mg}, 1.84 \mathrm{mmol})$ were added and reaction mixture was stirred at room temperature for $15 \mathrm{~min}$. A solution of C-8a $(1.26 \mathrm{~g}, 1.54 \mathrm{mmol})$ in dry DCM $(10 \mathrm{~mL})$ was added to the reaction mixture and stirring proceeded overnight. Reaction was quenched with sat. aq. $\mathrm{NaHCO}_{3}$. Layers were separated and aqueous one was extracted with DCM. Combined organics were dried over $\mathrm{K}_{2} \mathrm{CO}_{3}$, filtered and solvent removed under reduced pressure. Crude product $\left(2.3 \mathrm{~g}\right.$, ES+ m/z $\left.1247[\mathrm{M}+\mathrm{H}]^{+}\right)$was dissolved in THF (30 mL). LiOH. $\mathrm{H}_{2} \mathrm{O}(390 \mathrm{mg}, 9.29 \mathrm{mmol})$ was dissolved in water $(10 \mathrm{~mL})$ and added to the reaction mixture. It was stirred at room temperature for $4 \mathrm{~h}$. Organic solvent was removed under reduced pressure and remaining solution was diluted with water and acidified to $\mathrm{pH}$ 4.5. Extractions with DCM were performed at $\mathrm{pH} 4,7$ and 9.5. Combined extracts at basic $\mathrm{pH}$ were evaporated under removed pressure and residue $(450 \mathrm{mg})$ was used in the next synthetic step without further purification. ES+ m/z $926.7[\mathrm{M}+\mathrm{H}]^{+}$. 

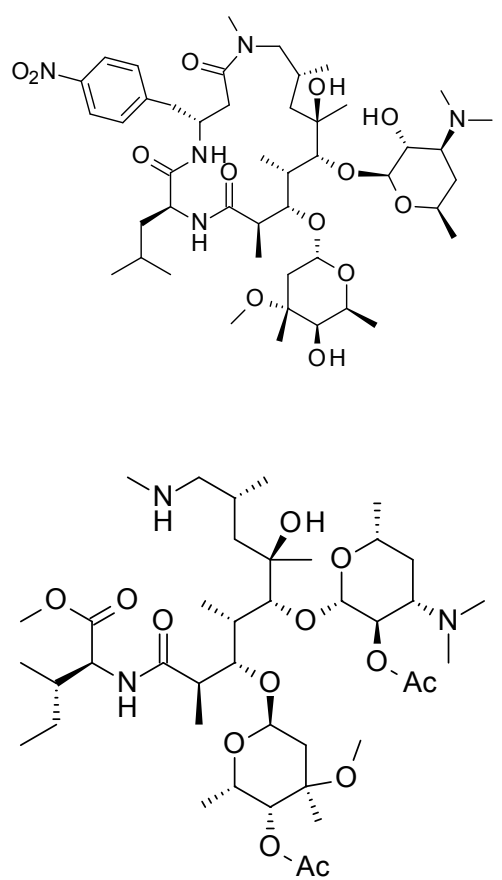

$(2 S, 5 R, 10 R, 12 R, 13 R, 14 S, 15 S, 16 R)-5$-[(4-nitrophenyl)methyl]-13( $\beta$-Ddesosaminyl)oxy-12-hydroxy-15( $\alpha$-L-cladinosyl)oxy-2-isobutyl-8,10,12,14,16pentamethyl-1,4,8-triazacycloheptadecane-3,7,17-trione (D-10)

To a solution of C-8b (450 mg, $0.49 \mathrm{mmol}$ ) in dry DMF ( $20 \mathrm{~mL}$ ), HATU $(227 \mathrm{mg}, 0.73$ mmol), DIPEA ( $0.127 \mathrm{~mL}, 0.73 \mathrm{mmol}$ ) were added and reaction mixture was stirred at room temperature for $0.5 \mathrm{~h}$. Extraction with sat. aq. $\mathrm{NaHCO}_{3}$ and EtOAc was performed. Combined organics were and reaction mixture was stirred at room temperature overnight, sat. $\mathrm{NaHCO}_{3}$ was added and reaction mixture was extracted with EtAOc. Combined organics were well washed with brine, dried over $\mathrm{Na}_{2} \mathrm{SO}_{4}$ and evaporated to dryness. Crude product (ca $400 \mathrm{mg}$ ) was dissolved in methanol $(50 \mathrm{~mL}$ ) and used in the next synthetic step without further purification. ES+ m/z $908.7[\mathrm{M}+\mathrm{H}]^{+}$.

[(2S,3R,4S,6R)-2-[(1R,2S,3S,4R)-3-[(2R,4R,5R,6S)-5-acetoxy-4-methoxy-4,6-dimethyltetrahydropyran-2-yl]oxy-1-[(1R,3R)-1-hydroxy-1,3-dimethyl-4(methylamino)butyl]-5-[[(1S,2S)-1-methoxycarbonyl-2-methyl-butyl]amino]-2,4dimethyl-5-oxo-pentoxy]-4-(dimethylamino)-6-methyl-tetrahydropyran-3yl] oxyactinium (C-9a)

To a solution of B-3 (900 mg, $1 \mathrm{mmol})$ in dry DCM, (30 mL), TMP (0.69 mL, $4.09 \mathrm{mmol})$, HATU (380 mg, $1 \mathrm{mmol}$ ) and HOAt (140 $\mathrm{mg}, 1.03 \mathrm{mmol}$ ) were added and reaction mixture was stirred at room temperature for $30 \mathrm{~min}$. L-isoleucine methyl ester $\mathrm{HCl}$ salt ( $180 \mathrm{mg}, 1 \mathrm{mmol}$ ) was added to the reaction mixture and stirring proceeded overnight. Reaction was quenched with sat. aq. $\mathrm{NaHCO}_{3}$. Layers were separated and aqueous one was extracted with DCM. Combined organics were dried over $\mathrm{K}_{2} \mathrm{CO}_{3}$. Solvent was removed under reduced pressure and crude product thus obtained was dissolved in DMF (20 mL). Piperidine $(0.25 \mathrm{~mL}, 2.54 \mathrm{mmol})$ was added. Reaction mixture was stirred at room temperature overnight. It was separated between sat. aq. $\mathrm{NaHCO}_{3}$ and EtOAc. Combined organics were washed with brine, dried over $\mathrm{K}_{2} \mathrm{CO}_{3}$, filtered and solvent removed under reduced pressure. The crude product $(1.14 \mathrm{~g})$ thus obtained was used in the next synthetic step without further purification. ES+ m/z $818.7[\mathrm{M}+\mathrm{H}]^{+}$.

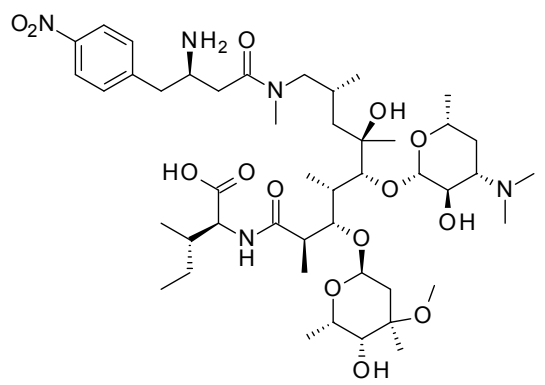

$(2 S, 3 S)-2-[[(2 R, 3 S, 4 S, 5 R, 6 R, 8 R)-9-[[(3 R)-3$-amino-4-(4-nitrophenyl)butanoyl]methyl-amino]-5( $\beta$-D-desosaminyl)oxy-6-hydroxy-3( $\alpha$-L-cladinosyl)oxy-2,4,6,8tetramethyl-nonanoyl]amino]-3-methyl-pentanoic acid (C-9b)

To a solution of Fmoc-( $R$ )-3-amino-4nitro-phenyl)-butyric acid (630 mg, $1.4 \mathrm{mmol})$ in dry DCM $(20 \mathrm{~mL})$ TMP $(0.59 \mathrm{~mL}, 3.5 \mathrm{mmol})$, HATU $(630 \mathrm{mg}, 1.4 \mathrm{mmol})$ and HOAt $(230 \mathrm{mg}, 1.69 \mathrm{mmol})$ were added and reaction mixture was stirred at room temperature for $30 \mathrm{~min}$. A solution of C-9a $(1.13 \mathrm{~g}, 1.4 \mathrm{mmol})$ in dry DCM $(10 \mathrm{~mL})$ was added to the reaction mixture and stirring proceeded overnight. Reaction was quenched with sat. aq. $\mathrm{NaHCO}_{3}$. Layers were separated and aqueous one was extracted with DCM. Combined organics were dried over $\mathrm{K}_{2} \mathrm{CO}_{3}$, filtered and solvent removed under reduced pressure. Crude product was dissolved in THF $(20 \mathrm{~mL})$. LiOH. $\mathrm{H}_{2} \mathrm{O}(350 \mathrm{mg}, 8.43 \mathrm{mmol})$ was dissolved in water $(20 \mathrm{~mL})$ and added to the reaction mixture. It was stirred at room temperature for $4 \mathrm{~h}$. Organic solvent was removed under reduced pressure and remaining solution was diluted with water and acidified to $\mathrm{pH}$ 4.5. Extractions with DCM were performed at $\mathrm{pH} \mathrm{4,7}$ and 9.5. Combined extracts at basic $\mathrm{pH}$ were evaporated under removed pressure and residue $(480 \mathrm{mg})$ was used in the next synthetic step without further purification. $\mathrm{ES}+\mathrm{m} / \mathrm{z} 926.7[\mathrm{M}+\mathrm{H}]^{+}$.

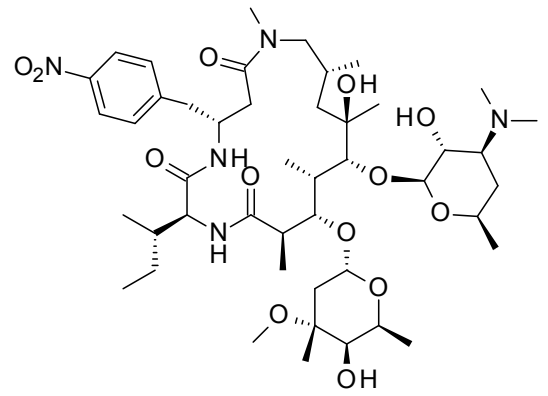

$(2 S, 5 R, 10 R, 12 R, 13 R, 14 S, 15 S, 16 R)-5-[(4-n i t r o p h e n y l) m e t h y l]-13(\beta-\mathrm{D}-$ desosaminyl)oxy-12-hydroxy-15( $\alpha$-L-cladinosyl)oxy-8,10,12,14,16-pentamethyl2-[(1S)-1-methylpropyl]-1,4,8-triazacycloheptadecane-3,7,17-trione (D-11) To a solution of C-9b (480 g, $0.52 \mathrm{mmol})$ in dry DMF (20 mL), HATU (297 mg, 0.78 $\mathrm{mmol}$ ), DIPEA (0.136 $\mathrm{mL}, 0.78 \mathrm{mmol}$ ) were added and reaction mixture was stirred at room temperature for $0.5 \mathrm{~h}$. Extraction with sat. aq. $\mathrm{NaHCO}_{3}$ and EtOAc was performed. Combined organics were and reaction mixture was stirred at room temperature overnight, sat. $\mathrm{NaHCO}_{3}$ was added and reaction mixture was extracted with EtAOc. Combined organics were well washed with brine, dried over $\mathrm{Na}_{2} \mathrm{SO}_{4}$ and evaporated to dryness. Crude product (ca $480 \mathrm{mg}$ ) was dissolved in methanol $(50 \mathrm{~mL})$ and used in the next synthetic step without further purification. ES+ $\mathrm{m} / \mathrm{z}$

$908.7[\mathrm{M}+\mathrm{H}]^{+}$. 
Step 4a. Side chain modification (reduction of nitro group). Synthesis of intermediates E (Scheme S3)

A mixture of corresponding analogue $\mathbf{D}(1 \mathrm{eq})$ and palladium on carbon $(10 \% \mathrm{wt}$.) in $\mathrm{MeOH}$ was stirred under a hydrogen atmosphere (2.5 bar) at room temperature overnight. The reaction mixture was filtered through Celite and washed with $\mathrm{MeOH}$, filtrate concentrated and the residue suspended in EtOAc. The organic layer was washed with sat. $\mathrm{NaHCO}_{3}$, brine, dried over anhydrous $\mathrm{Na}_{2} \mathrm{SO}_{4}$ and concentrated under reduced pressure to give intermediate $\mathbf{E}$.

Table S10. Intermediates synthesized in Step 4 (reduction)

\begin{tabular}{|c|c|c|c|c|c|c|c|}
\hline INT & Starts from & Yield (\%) & $\begin{array}{l}{[\mathrm{M}+\mathrm{H}]^{+}} \\
(\mathrm{m} / \mathrm{z})\end{array}$ & INT & Starts from & Yield (\%) & $\begin{array}{l}{[\mathrm{M}+\mathrm{H}]^{+}} \\
(\mathrm{m} / \mathrm{z})\end{array}$ \\
\hline E-1a & D-1 (194 mg) & 91 & 864.7 & E-15 & D-15 (335 mg) & crude & 864.5 \\
\hline E-2 & D-2 (crude) & crude & 877 & E-16 & D-16 (405 mg) & crude & 864.6 \\
\hline E-3 & D-3 (268 mg) & quant. & 904.8 & E-17 & D-17 (515 mg) & crude & 864.5 \\
\hline E-4 & D-4 (245 mg) & 71 & & E-18 & D-18 (385 mg) & 93 & 864.6 \\
\hline E-5 & D-5 (100 mg) & 95 & 864.7 & E-19 & D-19 (600 mg) & 99 & 864.5 \\
\hline E-6 & D-6 (510 mg) & 99 & 864.6 & E-20 & D-20 (100 mg) & quant. & 864.5 \\
\hline E-7 & D-7 (155 mg) & 76 & 864.6 & E-21 & D-21 (75 mg) & 85 & 850.7 \\
\hline E-8 & D-8 (86 mg) & 24 & 836.6 & E-22 & D-22 (270 mg) & 87 & 850.5 \\
\hline E-9 & D-9 (59 mg) & 93 & 836.8 & E-23 & D-23 (403 mg) & quant. & 878.7 \\
\hline E-10 & D-10 (168 mg) & crude & 878.8 & E-24 & D-24 (187 mg) & 92 & 878.5 \\
\hline E-11 & D-11 (440 mg) & crude & 878.7 & E-25 & D-25 (396 mg) & 81 & 878.6 \\
\hline E-12 & D-12 (104 mg) & 85 & 878.8 & E-26 & D-26 (290 mg) & 40 & 892.7 \\
\hline E-13 & D-13 (88 mg) & 92 & 862.8 & E-27 & D-27 (206 mg) & 24 & 836.7 \\
\hline E-14 & D-14 (310 mg) & crude & 864.5 & & & & \\
\hline
\end{tabular}


<smiles>CC#CC</smiles>

Scheme S6: Synthesis of intermediates E-1b-E-1g

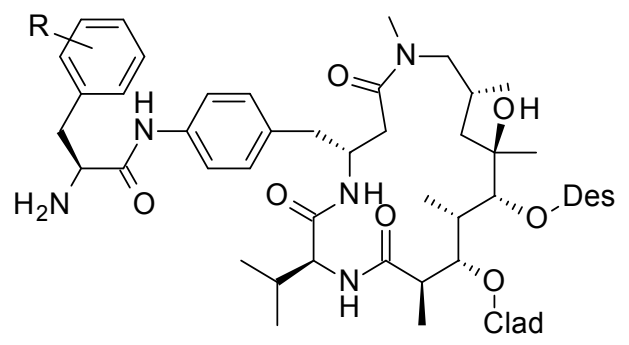

$E-1 b$ to $E-1 g$<smiles>CO[C@]1(C)C[C@H](C(C)(C)C)O[C@@H](C)[C@@H]1O</smiles>

\section{General procedure for the preparation of Intermediate E-1b-E-1g}

To a solution of E-1a (1 eq) in dry DMF, HATU (1.1 eq), DIPEA (2.2 eq) and corresponding $N$-Fmoc-amino acid (1.05 eq) were added. Reaction mixture was stirred at room temperature for $1 \mathrm{~h}$. Then piperidine $(1.5 \mathrm{eq})$ was added and reaction mixture was stirred at room temperature overnight. DMF was evaporated and residue was dissolved in DCM. Mixture was washed with sat. $\mathrm{NaHCO}_{3}(3 \mathrm{x})$. Organic layer was washed with water (3x), dried over anhydrous $\mathrm{Na}_{2} \mathrm{SO}_{4}$, filtered and evaporated to dryness to get crude. Crude was purified by column chromatography, using DCM:MeOH: $\mathrm{NH}_{4} \mathrm{OH}=10: 1: 0.1$ as eluent to get corresponding product (E-1b to E-1g).

Table S11. Intermediates synthesized in Step 4b (amidation)

\begin{tabular}{|c|c|c|c|c|}
\hline INT & $\mathbf{R}$ & Starts from & Yield (\%) & $\begin{array}{l}{[\mathrm{M}+\mathrm{H}]^{+}} \\
(\mathrm{m} / \mathrm{z})\end{array}$ \\
\hline E-1b & $2-\mathrm{Cl}$ & $\begin{array}{l}\text { Fmoc- }(S) \text {-2-chloro-Phe-OH (760 mg) } \\
\text { E-1a }(1.3 \mathrm{~g})\end{array}$ & 71 & 1045.4 \\
\hline E-1c & 2,4-diCl & $\begin{array}{l}\text { Fmoc- }(S)-2,4-\text { di-chloro-Phe-OH }(139 \mathrm{mg}) \\
\text { E-1a }(250 \mathrm{mg})\end{array}$ & 77 & 1079.5 \\
\hline E-1d & 2,6-diCl & $\begin{array}{l}\text { Fmoc-(S)-2,6-di-chloro-Phe-OH (136 mg) } \\
\text { E-1a (214 mg) }\end{array}$ & 64 & 1079.7 \\
\hline E-1e & $2-\mathrm{F}$ & $\begin{array}{l}\text { Fmoc-(S)-2-fluoroPhe-OH (196 mg) } \\
\text { E-1a }(379 \mathrm{mg})\end{array}$ & 85 & 1029.6 \\
\hline E-1f & 2-Me & $\begin{array}{l}\text { Fmoc- }(S)-2-\text { methyl-Phe-OH (123 mg) } \\
\text { E-1a (250 mg) }\end{array}$ & 78 & 1025.6 \\
\hline E-1g & - & $\begin{array}{l}\text { Fmoc- }(S)-\mathrm{Phe}-\mathrm{OH}(94 \mathrm{mg}) \\
\text { E-1a }(200 \mathrm{mg})\end{array}$ & 62 & 1011.6 \\
\hline
\end{tabular}




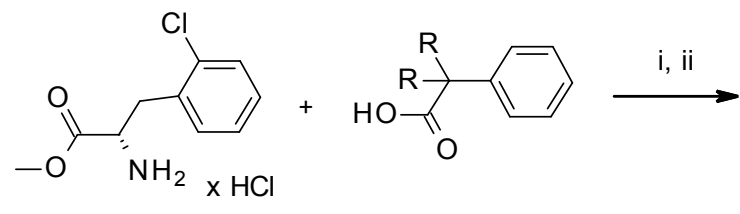

Scheme S7. Synthesis of intermediates 64-66

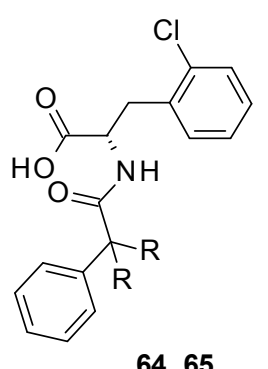

64,65

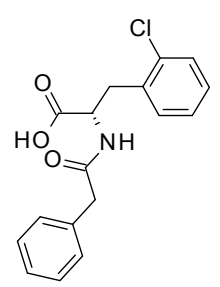

(S)-3-(2-chlorophenyl)-2-[(2-phenylacetyl)amino]propanoic acid (64)

A round-bottom flask was charged under argon with phenylacetic acid (816 mg, $6 \mathrm{mmol}),(2 S)$-methyl-2amino-3-(2-chlorophenyl)-propyonate hydrochloride (1 g, $4 \mathrm{mmol})$ and DMF (5 mL). DIPEA (2 $\mathrm{mL}, 12$ $\mathrm{mmol}$ ) and HATU (850 $\mathrm{mg}, 2.23 \mathrm{mmol}$ ) were added and yellow turbid solution was stirred at room temperature for $18 \mathrm{~h}$. HATU (700 mg, $1.84 \mathrm{mmol}$ ) was added and reaction mixture was stirred under the same conditions for $3 \mathrm{~h}$ more. Reaction was quenched with sat. $\mathrm{NaHCO}_{3}(15 \mathrm{~mL})$ and extracted with $\mathrm{DCM}$ $(3 \times 10 \mathrm{~mL})$. Combined organics were washed with water $(3 \times 10 \mathrm{~mL})$ and volatiles removed under reduced pressure. The residue was taken up in THF $(5 \mathrm{~mL})$. Water $(5 \mathrm{~mL})$ and LiOH $(515 \mathrm{mg})$ were added and reaction mixture was stirred at room temperature for $3 \mathrm{~h}$. THF was evaporated under vacuum. The remaining suspension turned to a thick gel. It was diluted with water till it turned to a solution and $\mathrm{pH}$ was lowered from 12 to 3.5. The white precipitate thus formed was filtered and washed with water. The product thus obtained was used in the next step without further purification. Yield $53 \%$ (380 mg). ES ${ }^{+} \mathrm{m} / \mathrm{z} 318.2 / 320.2[\mathrm{M}+\mathrm{H}]^{+} .{ }^{1} \mathrm{H}-\mathrm{NMR}\left(300 \mathrm{MHz}, \mathrm{DMSO}-\mathrm{d}_{6}\right) \delta / \mathrm{ppm:} 12.75$ (bs, $\left.1 \mathrm{H}\right)$; $8.48(\mathrm{~d}, J=8.4 \mathrm{~Hz}, 1 \mathrm{H}) ; 7.38(\mathrm{dd}, J=7.7 \mathrm{~Hz}, J=1.8 \mathrm{~Hz}, 1 \mathrm{H}) ; 7.16-7.31(\mathrm{~m}, 6 \mathrm{H}) ; 7.07-7.1(\mathrm{~m}, 2 \mathrm{H})$ ); $4.53(\mathrm{ddd}, J=10.3 \mathrm{~Hz}, J=8.4$ $\mathrm{Hz}, J=4.7 \mathrm{~Hz}, 1 \mathrm{H}) ; 3.37$ (s, 2H); $3.26(\mathrm{dd}, J=13.7 \mathrm{~Hz}, J=4.7 \mathrm{~Hz}, 1 \mathrm{H}) ; 2.91(\mathrm{dd}, J=13.7 \mathrm{~Hz}, J=10.3 \mathrm{~Hz}, 1 \mathrm{H}$ ).

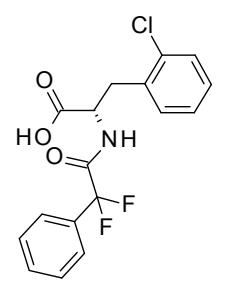

(S)-3-(2-chlorophenyl)-2-[(2,2-difluoro-2-phenyl-acetyl)amino]propanoic acid (65)

A round-bottom flask was charged under argon with 4-fluoro-phenylacetic acid (423 mg, $2.75 \mathrm{mmol}$ ), (S)2'-chlorophenylalanine methyl ester hydrochloride (625 mg, $2.5 \mathrm{mmol}$ ) and DMF (5 mL). DIPEA (1.3 $\mathrm{mL}$, $7.5 \mathrm{mmol}$ ) and HATU (450 mg, $3.25 \mathrm{mmol}$ ) were added and reaction mixture was stirred at room temperature for $18 \mathrm{~h}$. Reaction was quenched with sat. aq. $\mathrm{NaHCO}_{3}(15 \mathrm{~mL})$ and extracted with DCM (3 x $10 \mathrm{~mL})$. Combined organics were washed with water (3 x $10 \mathrm{~mL})$ and volatiles removed under reduced pressure. The residue was taken up in THF $(5 \mathrm{~mL})$. Water $(5 \mathrm{~mL})$ and LiOH $(515 \mathrm{mg})$ were added and reaction mixture was stirred at room temperature for $3 \mathrm{~h}$. THF was evaporated under vacuum and residues were diluted with water $(80 \mathrm{~mL})$ under sonication. The $\mathrm{pH}$ was lowered from 12 to 3.5 . The white precipitate thus formed was filtered washed with water and dried by suction. Yield $37 \%$ (330 mg). ES+ m/z 354.2/356.2 [M+H] ${ }^{+}{ }^{1} \mathrm{H}-\mathrm{NMR}(300 \mathrm{MHz}$, DMSO-d ${ }_{6}$ ) $\delta /$ ppm: 13.1 (bs, $\left.1 \mathrm{H}\right) ; 9.3(\mathrm{~d}, J=8.9 \mathrm{~Hz}, 1 \mathrm{H}) ; 7.06-7.53(\mathrm{~m}, 9 \mathrm{H}) ; 4.61(\mathrm{ddd}, J=11.1 \mathrm{~Hz}, J=8.9 \mathrm{~Hz}, J=4 \mathrm{~Hz}, 1 \mathrm{H}) ; 3.37$ (dd, $J=14 \mathrm{~Hz}, J=4 \mathrm{~Hz}, 1 \mathrm{H}) ; 3.06(\mathrm{dd}, J=14 \mathrm{~Hz}, J=11.1 \mathrm{~Hz}, 1 \mathrm{H})$.

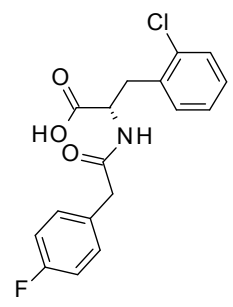

(2S)-3-(2-chlorophenyl)-2-[[2-(4-fluorophenyl)acetyl]amino]propanoic acid (66)

A round-bottom flask was charged under argon with 4-fluoro-phenylacetic acid (423 mg, $2.75 \mathrm{mmol}$ ), (S) 2'-chlorophenylalanine methyl ester hydrochloride ( $625 \mathrm{mg}, 2.5 \mathrm{mmol})$ and DMF (5 mL). DIPEA (1.3 mL, $7.5 \mathrm{mmol}$ ) and HATU (450 mg, $3.25 \mathrm{mmol}$ ) were added and reaction mixture was stirred at r.t. for $18 \mathrm{~h}$. Reaction was quenched with sat. $\mathrm{NaHCO}_{3}(15 \mathrm{~mL})$ and extracted with DCM $(3 \times 10 \mathrm{~mL})$. Combined organics were washed with water $(3 \times 10 \mathrm{~mL})$ and volatiles removed under reduced pressure. The residue was taken up in THF ( $5 \mathrm{~mL})$. Water $(5 \mathrm{~mL})$ and LiOH $(515 \mathrm{mg})$ were added and reaction mixture was stirred at room temperature for $3 \mathrm{~h}$. THF was evaporated under vacuum. Sample was dissolved in water $(80 \mathrm{~mL})$ by sonication and $\mathrm{pH}$ was lowered from 12 to 3.5. The white precipitate thus formed was filtered and washed with water. Yield $40 \%$ (335 mg). ES ${ }^{+} \mathrm{m} / \mathrm{z} 336.1 / 338.1[\mathrm{M}+\mathrm{H}]^{+} .{ }^{1} \mathrm{H}-\mathrm{NMR}\left(300 \mathrm{MHz}, \mathrm{DMSO}-\mathrm{d}_{6}\right) \delta / \mathrm{ppm:} 12.75$ (bs, $\left.1 \mathrm{H}\right) ; 8.48(\mathrm{~d}$, $J=8.4 \mathrm{~Hz}, 1 \mathrm{H}) ; 7.38(\mathrm{dd}, J=7.7 \mathrm{~Hz}, J=1.8 \mathrm{~Hz}, 1 \mathrm{H}) ; 7.16-7.31(\mathrm{~m}, 3 \mathrm{H}) ; 7-7.14(\mathrm{~m}, 3 \mathrm{H}) ; 4.51(\mathrm{ddd}, J=10.3 \mathrm{~Hz}, \mathrm{~J}=8.4 \mathrm{~Hz}, J=4.7$ $\mathrm{Hz}, 1 \mathrm{H}) ; 3.35(\mathrm{~s}, 2 \mathrm{H}) ; 3.25(\mathrm{dd}, J=13.7 \mathrm{~Hz}, \mathrm{~J}=4.7 \mathrm{~Hz}, 1 \mathrm{H}) ; 2.9(\mathrm{dd}, J=13.7 \mathrm{~Hz}, J=10.3 \mathrm{~Hz}, 1 \mathrm{H})$. 


\section{Step 5: General procedure for the synthesis of compounds 1-27, 34, 40, 45 and 46}

To a solution of corresponding intermediate $\mathbf{E}$ (1 eq) in dry DMF, HATU (1.5 eq), DIPEA (1.5 eq) and intermediates 64-66 (1 eq) were added and stirred at room temperature for $1 \mathrm{~h}$. After reaction was complete, DMF was evaporated and then extracted with water and DCM. Organic layer was dried over anhydrous $\mathrm{Na}_{2} \mathrm{SO}_{4}$, filtered and evaporated to dryness. The crude product was purified by prep HPLC purification (extended A, high $\mathrm{pH}$ ) or by column chromatography using DCM:MeOH: $\mathrm{NH}_{4} \mathrm{OH}=$ 10:1:0.1 as eluent to get title compound.

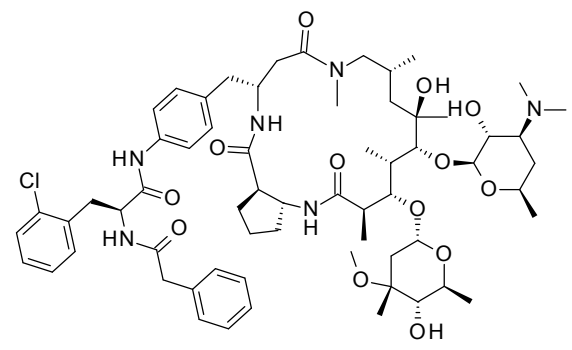

(2S)-3-(2-chlorophenyl)- $N$-[4-[[(1R,4R,5S,6S,7R,8R,10R,15R,18R)-7-( $\beta$-Ddesosaminyl)oxy-8-hydroxy-5-( $\alpha$-L-cladinosyl)oxy-4,6,8,10,12-pentamethyl3,13,17-trioxo-2,12,16-triazabicyclo[16.3.0]henicosan-15-yl]methyl]phenyl]-2[(2-phenylacetyl)amino]propan amide (1)

Following general procedure for Step 5: starting from $64(36 \mathrm{mg}, 0.11 \mathrm{mmol})$ and E-2 (100 $\mathrm{mg}, 0.11 \mathrm{mmol}$ ) title product was obtained by prep HPLC purification (15 mg, yield $12 \%$, purity $98.41 \%) . \mathrm{ES}^{+} \mathrm{m} / \mathrm{z} 1176.15[\mathrm{MH}]^{+} .{ }^{1} \mathrm{H}$ NMR $(600 \mathrm{MHz}$, DMSO-d $\left.\mathrm{d}_{6}\right) \delta / \mathrm{ppm} 9.97$ (br s, 1H), 8.49-8.46 (m, 2H), 8.18-8.13 (m, 1H), 7.82-7.77 (m, 1H), 7.45-7.41 (m, 2H), 7.4-7.37 (m, 1H), $7.29(\mathrm{br} \mathrm{d}, J=7.3 \mathrm{~Hz}, 2 \mathrm{H}), 7.26$ (br s, $1 \mathrm{H}), 7.21-7.17(\mathrm{~m}, J=0.9 \mathrm{~Hz}, 2 \mathrm{H}), 7.14(\mathrm{br} \mathrm{d}, J=8.6 \mathrm{~Hz}, 2 \mathrm{H}), 7.11-7.07(\mathrm{~m}, 2 \mathrm{H})$, 4.79 (br s, 2H), 4.57-4.52 (m, 2H), 4.4-4.33 (m, 2H), 4.31 (br s, 1H), 4.2 (br s, 1H), 4.09 (br s, 1H), 3.97 (br s, 1H), 3.71-3.65 $(\mathrm{m}, 2 \mathrm{H}), 3.62-3.59(\mathrm{~m}, 1 \mathrm{H}), 3.22(\mathrm{~s}, 6 \mathrm{H}), 3.18(\mathrm{~s}, 3 \mathrm{H}), 3.16(\mathrm{~d}, J=5.7 \mathrm{~Hz}, 2 \mathrm{H}), 3.11-3.07(\mathrm{~m}, 3 \mathrm{H}), 3.01(\mathrm{br} \mathrm{s}, 1 \mathrm{H}), 2.92-2.9(\mathrm{~m}$, $2 \mathrm{H}), 2.8-2.76(\mathrm{~m}, 1 \mathrm{H}), 2.76-2.7(\mathrm{~m}, 1 \mathrm{H}), 2.63-2.6(\mathrm{~m}, 3 \mathrm{H}), 2.56(\mathrm{br} \mathrm{d}, J=2.2 \mathrm{~Hz}, 1 \mathrm{H}), 2.4-2.39(\mathrm{~m}, 2 \mathrm{H}), 2.32-2.27(\mathrm{~m}, 1 \mathrm{H}), 2.23$ (s, 6H), 2.09-2.04 (m, 1H), 1.8-1.76 (m, 1H), 1.76-1.7 (m, 1H), $1.6($ br s, 1H), 1.53-1.48 (m, 1H), 1.33-1.22 (m, 2H), 1.13-1.08 $(\mathrm{m}, 10 \mathrm{H}), 1(\mathrm{t}, J=6.9 \mathrm{~Hz}, 3 \mathrm{H}), 0.88(\mathrm{~d}, J=6.4 \mathrm{~Hz}, 3 \mathrm{H})$.

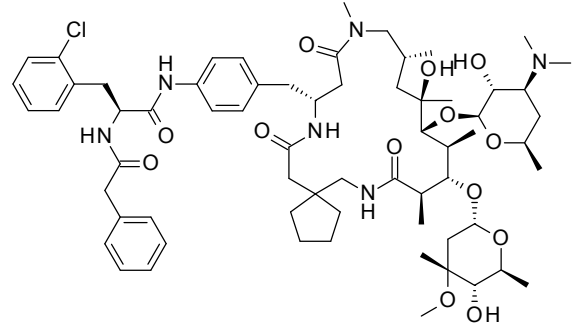

(2S)-3-(2-chlorophenyl)- $N$-[4-[[(9R,10S,11S,12R,13R,15R,20R)-12-( $\beta$-D-

desosaminyl)oxy-13-hydroxy-10-( $\alpha$-L-cladinosyl)oxy-9,11,13,15,17-

pentamethyl-8,18,22-trioxo-7,17,21-triazaspiro[4.18]tricosan-20-

yl]methyl]phenyl]-2-[(2-phenylacetyl)amino]propanamide (2)

Following general procedure for Step 5: starting from $64(93 \mathrm{mg}, 0.292 \mathrm{mmol})$ and E-3 $(240 \mathrm{mg}, 0.26 \mathrm{mmol}$ ) title product was obtained (114.4 $\mathrm{mg}$, yield $36 \%$, purity $96.6 \%$ ) as a white solid foam. Purification was performed by flash column chromatography with DCM:MeOH: $\mathrm{NH}_{4} \mathrm{OH}=90: 9: 1.5$ as an eluent. $\mathrm{ES}^{+} \mathrm{m} / \mathrm{z}$ $1203.71[\mathrm{M}+\mathrm{H}]^{+} .{ }^{1} \mathrm{H}$ NMR $(500 \mathrm{MHz}$, DMSO-d 6 ) $\delta / \mathrm{ppm} 10.01-9.99(\mathrm{~m}, 1 \mathrm{H}), 8.5(\mathrm{~d}$, $J=8.2 \mathrm{~Hz}, 1 \mathrm{H}), 8.04(\mathrm{br} \mathrm{t}, J=5.5 \mathrm{~Hz}, 1 \mathrm{H}), 7.85(\mathrm{br} \mathrm{d}, J=7.9 \mathrm{~Hz}, 1 \mathrm{H}), 7.49-7.45(\mathrm{~m}$, $2 \mathrm{H}), 7.4(\mathrm{dd}, J=7.8,1.4 \mathrm{~Hz}, 1 \mathrm{H}), 7.31(\mathrm{dd}, J=7.3,1.8 \mathrm{~Hz}, 1 \mathrm{H}), 7.27-7.22(\mathrm{~m}, 3 \mathrm{H}), 7.22-7.17(\mathrm{~m}, 2 \mathrm{H}), 7.17-7.12(\mathrm{~m}, 4 \mathrm{H}), 4.85-$ $4.73(\mathrm{~m}, 2 \mathrm{H}), 4.36(\mathrm{~d}, J=7 \mathrm{~Hz}, 1 \mathrm{H}), 4.28(\mathrm{~d}, J=8.9 \mathrm{~Hz}, 1 \mathrm{H}), 4.24(\mathrm{~s}, 1 \mathrm{H}), 4.23-4.2(\mathrm{~m}, 1 \mathrm{H}), 4.14(\mathrm{br} \mathrm{s}, 2 \mathrm{H}), 4.08-4.04(\mathrm{~m}, 2 \mathrm{H})$, 3.60-3.53 (m, 1H), 3.48-3.4 (m, 4H), 3.28-3.16 (m, 5H), 3.08-2.97 (m, 3H), 2.94-2.87 (m, 3H), 2.78-2.74 (m, 4H), 2.68-2.57 (m, 2H), 2.28-2.21 (m, 8H), 2.19-2.12 (m, 1H), 2.12-2.05 (m, 1H), $2.01(\mathrm{br} \mathrm{d}, J=12.8 \mathrm{~Hz}, 1 \mathrm{H}), 1.93-1.86(\mathrm{~m}, 2 \mathrm{H}), 1.65-1.59$ $(\mathrm{m}, 1 \mathrm{H}), 1.59-1.54(\mathrm{~m}, 1 \mathrm{H}), 1.53-1.42(\mathrm{~m}, 6 \mathrm{H}), 1.28-1.23(\mathrm{~m}, 2 \mathrm{H}), 1.21-1.04(\mathrm{~m}, 17 \mathrm{H}), 1(\mathrm{br} \mathrm{d}, J=7 \mathrm{~Hz}, 2 \mathrm{H}), 0.84(\mathrm{br} \mathrm{d}, J=6.7$ $\mathrm{Hz}, 1 \mathrm{H}), 0.81(\mathrm{~d}, J=6.4 \mathrm{~Hz}, 3 \mathrm{H})$.

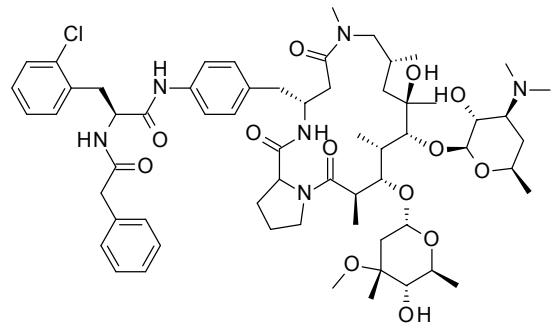

(2S)-3-(2-chlorophenyl)- $N$-[4-[[(3R,4S,5S,6R,7R,9R,14R)-6-( $(\beta$-Ddesosaminyl)oxy-7-hydroxy-4-( $\alpha$-L-cladinosyl)oxy-3,5,7,9,11-pentamethyl2,12,16-trioxo-1,11,15-triazabicyclo[15.3.0]icosan-14-yl]methyl]phenyl]-2-[(2phenylacetyl)amino]propanamide (3)

Following general procedure for Step 5: starting from 64 (33 mg, $0.104 \mathrm{mmol})$ and E-4 (90 mg, $0.104 \mathrm{mmol}$ ) title product was obtained ( $44 \mathrm{mg}$, yield $36 \%$,purity 98.8 $\%$ ) by prep HPLC purification. $\mathrm{ES}^{+} \mathrm{m} / \mathrm{z} 1161.64[\mathrm{M}+\mathrm{H}]^{+}$. Two sets of signals in the NMR (most likely conformers). ${ }^{1} \mathrm{H}$ NMR (500 MHz, DMSO-d 6 ) $\delta / \mathrm{ppm} 10.04(\mathrm{~s}, 1 \mathrm{H})$, $9.96(\mathrm{~s}, 1 \mathrm{H}), 8.54-8.45(\mathrm{~m}, 3 \mathrm{H}), 7.53(\mathrm{br} \mathrm{d}, J=8.2 \mathrm{~Hz}, 3 \mathrm{H}), 7.46(\mathrm{br} \mathrm{d}, J=8.2 \mathrm{~Hz}, 1 \mathrm{H})$, $7.39(\mathrm{~d}, J=7.9 \mathrm{~Hz}, 3 \mathrm{H}), 7.3(\mathrm{t}, J=6.9 \mathrm{~Hz}, 3 \mathrm{H}), 7.27-7.23(\mathrm{~m}, 7 \mathrm{H}), 7.22-7.17(\mathrm{~m}, 6 \mathrm{H}), 7.15(\mathrm{br} \mathrm{d}, J=7.9 \mathrm{~Hz}, 6 \mathrm{H}), 7.11(\mathrm{br} \mathrm{d}, J=$ $8.5 \mathrm{~Hz}, 4 \mathrm{H}), 4.80-4.76(\mathrm{~m}, 2 \mathrm{H}), 4.41-4.35(\mathrm{~m}, 3 \mathrm{H}), 4.17(\mathrm{br} \mathrm{d}, J=8.5 \mathrm{~Hz}, 3 \mathrm{H}), 4.12-4.06(\mathrm{~m}, 5 \mathrm{H}), 4.04(\mathrm{br} \mathrm{d}, J=10.4 \mathrm{~Hz}, 1 \mathrm{H})$, 3.81-3.76 (m, 2H), 3.46 (br d, $J=9.8 \mathrm{~Hz}, 5 \mathrm{H}), 3.24-3.15(\mathrm{~m}, 12 \mathrm{H}), 3.08-3.03(\mathrm{~m}, 3 \mathrm{H}), 2.96-2.87(\mathrm{~m}, 7 \mathrm{H}), 2.68(\mathrm{br} \mathrm{s}, 5 \mathrm{H}), 2.55-$ $2.55(\mathrm{~m}, 1 \mathrm{H}), 2.44-2.39(\mathrm{~m}, 3 \mathrm{H}), 2.37-2.29(\mathrm{~m}, 12 \mathrm{H}), 2.27-2.23(\mathrm{~m}, 4 \mathrm{H}), 2.10-2.02(\mathrm{~m}, 4 \mathrm{H}), 1.71(\mathrm{br} \mathrm{s}, 2 \mathrm{H}), 1.64$ (br dd, $J=$ $18.8,8.1 \mathrm{~Hz}, 3 \mathrm{H}), 1.49-1.41(\mathrm{~m}, 4 \mathrm{H}), 1.24-1.08(\mathrm{~m}, 36 \mathrm{H}), 1.06-0.97(\mathrm{~m}, 17 \mathrm{H}), 0.93(\mathrm{br} \mathrm{d}, J=6.7 \mathrm{~Hz}, 4 \mathrm{H})$.

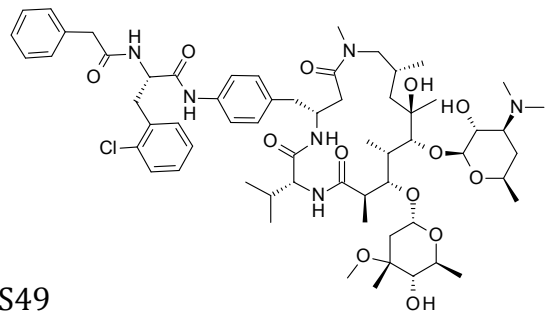

(2S)-3-(2-chlorophenyl)- $N$-[4-[[(2R,5R,10R,12R,13R,14S,15S,16R)-13-( $\beta$-Ddesosaminyl)oxy-12-hydroxy-15-( $\alpha$-L-cladinosyl)oxy-2-isopropyl-8,10,12,14,16pentamethyl-3,7,17-trioxo-1,4,8-triazacycloheptadec-5-yl]methyl]phenyl]-2-[(2phenylacetyl)amino] propanamide (5)

Following general procedure for Step 5: starting from $64(35 \mathrm{mg}, 0.11 \mathrm{mmol})$ and E-5 $(90 \mathrm{mg}, 0.1 \mathrm{mmol})$ title product was obtained $(27 \mathrm{mg}$, yield $21 \%$; purity 82.85 $\%$ ) by prep HPLC purification. ES+ m/z $1163.69[\mathrm{M}+\mathrm{H}]^{+} .{ }^{1} \mathrm{H}$ NMR $(500 \mathrm{MHz}$, DMSO- 
$\left.\mathrm{d}_{6}\right) \delta / \mathrm{ppm} 0.68(\mathrm{~m}, 6 \mathrm{H}), 0.77(\mathrm{~d}, 3 \mathrm{H}, J=7.1 \mathrm{~Hz}), 0.99-1.01(\mathrm{~m}, 7 \mathrm{H}), 1.05-1.07(\mathrm{~m}, 4 \mathrm{H}), 1.1-1.17(\mathrm{~m}, 12 \mathrm{H}), 1.25(\mathrm{~s}, 2 \mathrm{H}), 1.45(\mathrm{dd}$, $1 \mathrm{H}, J=14.74,4.15 \mathrm{~Hz}), 1.59(\mathrm{~d}, 1 \mathrm{H}, J=6.2 \mathrm{~Hz}), 1.69-1.7(\mathrm{~m}, 1 \mathrm{H}), 1.82-1.83(\mathrm{~m}, 1 \mathrm{H}), 2.22(\mathrm{~s}, 6 \mathrm{H}), 1.95-1.97(\mathrm{~m}, 2 \mathrm{H}), 2.27(\mathrm{br} \mathrm{s}$, 1H), 2.82 (br s, 1H), $2.71(\mathrm{~s}, 3 \mathrm{H}), 2.91-2.2 .95(\mathrm{~m}, 1 \mathrm{H}), 2.96$ (br. s. $1 \mathrm{H}), 3.03-3.08(\mathrm{~m}, 1 \mathrm{H}), 3.08-3.14(\mathrm{~m}, 2 \mathrm{H}), 3.17-3.18(\mathrm{~m}, 1 \mathrm{H})$, 3.18-3.19 (m, 1H), 3.21 ( s, 3H), 3.63 (br. s, 3H), 3.77-3.79 (m, 2H), 4-4.05 (m, 2H), $4.14(\mathrm{~s}, 1 \mathrm{H}), 4.31$ (br. s. 1H), 4.46-4.47(m, 1H), 4.74-4.76 (m, 1H), 4.99 (br. s. $1 \mathrm{H}), 7.08$ (d, 2H, $J=8.1$ ), 7.13 (d, 2H, $J=7.3 \mathrm{~Hz}), 7.18-7.17$ (m, 2H), 7.21-7.23 (m, 3H), 7.27 (d, $1 \mathrm{H}, J=7.25), 7.37(\mathrm{~d}, 1 \mathrm{H}, J=7.8 \mathrm{~Hz}), 7.42(\mathrm{~d}, 2 \mathrm{H}, J=8.25 \mathrm{~Hz}), 7.95(\mathrm{~d}, 1 \mathrm{H}, J=8.7 \mathrm{~Hz}), 8.13($ br. s., $1 \mathrm{H}), 8.47(\mathrm{~d}, 1 \mathrm{H}, J=5.8$ $\mathrm{Hz}), 9.65(\mathrm{~s}, 1 \mathrm{H})$.

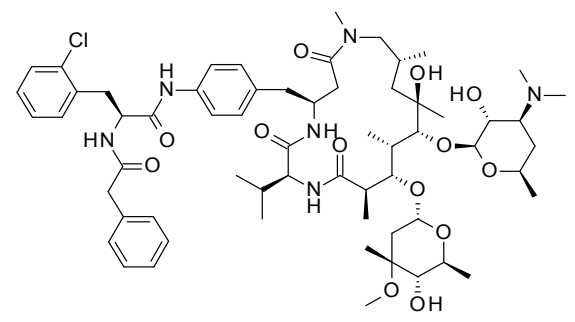

(2S)-3-(2-chlorophenyl)- $N$-[4-[[(2S,5S,10R,12R,13R,14S,15S,16R)-13-( $\beta$-Ddesosaminyl)oxy-12-hydroxy-15-( $\alpha$-L-cladinosyl)oxy-2-isopropyl8,10,12,14,16-pentamethyl-3,7,17-trioxo-1,4,8-triazacycloheptadec-5yl]methyl]phenyl]-2-[(2-phenylacetyl)amino]propanamide (6) Following general procedure for Step 5: starting from $64(37 \mathrm{mg}, 0.12 \mathrm{mmol})$ and E-6 (100 mg, $0.12 \mathrm{mmol})$ title product was obtained (15 mg, yield $11 \%$, purity $95.18 \%)$ by prep HPLC purification. ES ${ }^{+} \mathrm{m} / \mathrm{z} 1163.5[\mathrm{M}+\mathrm{H}]^{+} .{ }^{1} \mathrm{H}$ NMR $(500 \mathrm{MHz}$, DMSO-d $\left._{6}\right) \delta /$ ppm $9.99(\mathrm{~s}, 1 \mathrm{H}), 8.54-8.44(\mathrm{~m}, 1 \mathrm{H}), 7.5(\mathrm{br} \mathrm{d}, J=7 \mathrm{~Hz}, 1 \mathrm{H}), 7.46(\mathrm{br}$ $\mathrm{d}, J=8.2 \mathrm{~Hz}, 2 \mathrm{H}), 7.38($ br d, $J=7.9 \mathrm{~Hz}, 1 \mathrm{H}), 7.29(\mathrm{br} \mathrm{d}, J=6.7 \mathrm{~Hz}, 1 \mathrm{H}), 7.26-7.21$ (m, 3H), 7.19 (br d, $J=7 \mathrm{~Hz}, 2 \mathrm{H}), 7.14(\mathrm{br} \mathrm{d}, J=7.6 \mathrm{~Hz}, 4 \mathrm{H}), 4.82(\mathrm{br} \mathrm{d}, J=4.3 \mathrm{~Hz}, 1 \mathrm{H}), 4.79-4.73(\mathrm{~m}, 1 \mathrm{H}), 4.46(\mathrm{br} \mathrm{d}, J=7 \mathrm{~Hz}$, $1 \mathrm{H}), 4.29(\mathrm{br} \mathrm{d}, J=7.6 \mathrm{~Hz}, 1 \mathrm{H}), 4.25-4.13(\mathrm{~m}, 1 \mathrm{H}), 4.09-3.98(\mathrm{~m}, 4 \mathrm{H}), 3.97-3.9(\mathrm{~m}, 1 \mathrm{H}), 3.71-3.65(\mathrm{~m}, 1 \mathrm{H}), 3.64-3.56(\mathrm{~m}, 1 \mathrm{H})$, 3.5 (br s, 1H), 3.45 (br d, $J=8.5 \mathrm{~Hz}, 2 \mathrm{H}), 3.22(\mathrm{~s}, 3 \mathrm{H}), 3.19-3.14(\mathrm{~m}, 3 \mathrm{H}), 3.09-3.02(\mathrm{~m}, 2 \mathrm{H}), 2.96-2.85(\mathrm{~m}, 4 \mathrm{H}), 2.8(\mathrm{~s}, 2 \mathrm{H})$, 2.77-2.67 (m, 3H), 2.59-2.54 (m, 1H), $2.23(\mathrm{~s}, 6 \mathrm{H}), 1.6(\mathrm{br} \mathrm{d}, J=11.3 \mathrm{~Hz}, 1 \mathrm{H}), 1.5(\mathrm{br} \mathrm{dd}, J=15.1,4.4 \mathrm{~Hz}, 1 \mathrm{H}), 1.19(\mathrm{br} \mathrm{s}, 3 \mathrm{H})$, $1.15-1.07(\mathrm{~m}, 16 \mathrm{H}), 1.02-0.89(\mathrm{~m}, 9 \mathrm{H}), 0.8(\mathrm{br} \mathrm{d}, J=6.4 \mathrm{~Hz}, 1 \mathrm{H}), 0.76(\mathrm{br} \mathrm{d}, J=6.4 \mathrm{~Hz}, 3 \mathrm{H}), 0.67(\mathrm{br} \mathrm{d}, J=6.7 \mathrm{~Hz}, 2 \mathrm{H})$

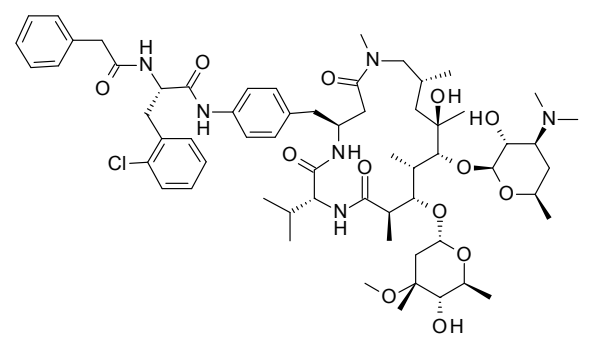

(2S)-3-(2-chlorophenyl)- $N$-[4-[[(2R,5S,10R,12R,13R,14S,15S,16R)-13$[(2 S, 3 R, 4 S, 6 R)$-4-(dimethylamino)-3-hydroxy-6-methyl-tetrahydropyran-2yl] oxy-12-hydroxy-15-( $\alpha$-L-cladinosyl)oxy-2-isopropyl-8,10,12,14,16pentamethyl-3,7,17-trioxo-1,4,8-triazacycloheptadec-5-yl]methyl]phenyl]-2[(2-phenylacetyl)amino]propanamide (7)

Following general procedure for Step 5: starting from $64(54 \mathrm{mg}, 0.17 \mathrm{mmol})$ and E-7 (145 mg, $0.17 \mathrm{mmol}$ ) title product was obtained (11 mg, yield $6 \%$, purity 93.5 \%) by prep HPLC purification. ES ${ }^{+} \mathrm{m} / \mathrm{z} 1163.72[\mathrm{M}+\mathrm{H}]^{+} .{ }^{1} \mathrm{H}$ NMR $(500 \mathrm{MHz}$, DMSO$\left.\mathrm{d}_{6}\right) \delta / \mathrm{ppm} 0.55(\mathrm{~d}, 3 \mathrm{H}, J=6.65), 0.61(\mathrm{~d}, 3 \mathrm{H}, J=6.7), 0.84(\mathrm{~d}, 3 \mathrm{H}, J=6.5), 0.99$ $1.02(\mathrm{~m}, 6 \mathrm{H}), 1.07-1.13(\mathrm{~m}, 16 \mathrm{H}), 1.22(\mathrm{~s}, 2 \mathrm{H}), 1.45(\mathrm{~d}, 1 \mathrm{H}, J=10), 1.59(\mathrm{~d}, 1 \mathrm{H}, J=$ 8.5), 1.64-1.68 (m, 1H), 1.79-1.8 (m, 1H), 1.98 (br s, 1H), 2.24 (s, 9H), 2.48-2.5 (br. s. 1H), 2.66-2.69 (m, 2H), 2.78 (s, 5H), 2.87$2.9(\mathrm{~m}, 4 \mathrm{H}), 3.04-3.07(\mathrm{~m}, 2 \mathrm{H}), 3.14-3.18(\mathrm{~m}, 2 \mathrm{H}), 3.21(\mathrm{~s}, 3 \mathrm{H}), 3.45(\mathrm{dq}, 3 \mathrm{H}, J=8.1,14.15), 3.6(\mathrm{br} \mathrm{s}, 1 \mathrm{H}), 3.64(\mathrm{~s}, 1 \mathrm{H}), 3.84(\mathrm{br}$ $\mathrm{s}, 1 \mathrm{H}), 4-4.03(\mathrm{~m}, 3 \mathrm{H}), 4.15(\mathrm{~s}, 1 \mathrm{H}), 4.26(\mathrm{~d}, 1 \mathrm{H}, J=6.1), 4.41(\mathrm{~d}, 1 \mathrm{H}, J=7.2), 4.77(\mathrm{dq}, 1 \mathrm{H}, J=6.5,8), 4.9(\mathrm{~d}, 1 \mathrm{H}, J=3.95), 7.13-$ $7.18(\mathrm{~m}, 6 \mathrm{H}), 7.2(\mathrm{~d}, 3 \mathrm{H}, J=3.9), 7.37-7.42(\mathrm{~m}, 3 \mathrm{H}), 8.05(\mathrm{t}, 2 \mathrm{H}, J=8.4,8.9), 8.48(\mathrm{~d}, 1 \mathrm{H}, J=8.35), 9.94(\mathrm{~s}, 1 \mathrm{H})$.

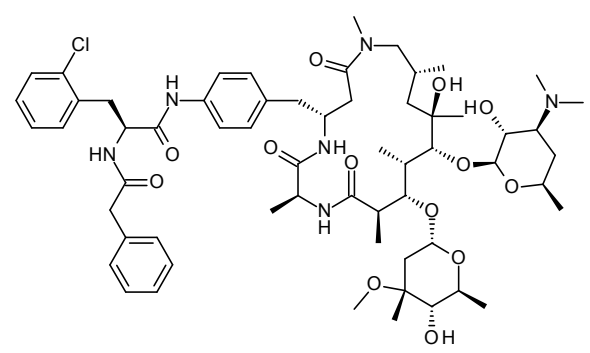

(2S)-3-(2-chlorophenyl)- $N$-[4-[[(2S,5R,10R,12R,13R,14S,15S,16R)-13-( $\beta$-Ddesosaminyl)oxy-12-hydroxy-15-( $\alpha$-L-cladinosyl)oxy-2,8,10,12,14,16hexamethyl-3,7,17-trioxo-1,4,8-triazacycloheptadec-5-yl]methyl]phenyl]-2[(2-phenylacetyl)amino]propanamide (8)

Following general procedure for Step 5: starting from $64(8 \mathrm{mg}, 0.024 \mathrm{mmol})$ and E-8 $(20 \mathrm{mg}, 0.024 \mathrm{mmol})$ title product was obtained $(17 \mathrm{mg}, 55.1 \%$, purity $88.4 \%$ ). Purification was performed by flash column chromatography with DCM:MeOH: $\mathrm{NH}_{4} \mathrm{OH}=90: 9: 0.9$ as an eluent. $\mathrm{ES}^{+} \mathrm{m} / \mathrm{z} 1135.74[\mathrm{M}+\mathrm{H}]^{+} .{ }^{1} \mathrm{H}$ NMR (500 MHz, DMSO-d $\left.\mathrm{d}_{6}\right) \delta / \mathrm{ppm} 10.40-10.2(\mathrm{~m}, 1 \mathrm{H}), 9.18-8.95(\mathrm{~m}, 1 \mathrm{H}), 8.06-7.97$ (m, 1H), $7.59(\mathrm{br} \mathrm{d}, J=6.1 \mathrm{~Hz}, 1 \mathrm{H}), 7.56-7.45(\mathrm{~m}, 3 \mathrm{H}), 7.39(\mathrm{br} \mathrm{d}, J=7.8 \mathrm{~Hz}, 1 \mathrm{H})$, $7.34(\mathrm{br} \mathrm{d}, J=5.5 \mathrm{~Hz}, 1 \mathrm{H}), 7.25-7.14(\mathrm{~m}, 8 \mathrm{H}), 7.11-7.07(\mathrm{~m}, 2 \mathrm{H}), 4.76-4.64(\mathrm{~m}, 2 \mathrm{H}), 4.56(\mathrm{br} \mathrm{d}, J=3.7 \mathrm{~Hz}, 1 \mathrm{H}), 4.43-4.4(\mathrm{~m}$, 1H), 4.23-4.18 (m, 1H), 4.14-4.06 (m, 3H), 4.05-3.98 (m, 2H), $3.94(\mathrm{br} \mathrm{d}, J=7 \mathrm{~Hz}, 1 \mathrm{H}), 3.63-3.55(\mathrm{~m}, 1 \mathrm{H}), 3.53-3.45(\mathrm{~m}, 4 \mathrm{H})$, $3.2(\mathrm{~d}, J=7.6 \mathrm{~Hz}, 4 \mathrm{H}), 3.14-3.04(\mathrm{~m}, 3 \mathrm{H}), 2.97(\mathrm{br} \mathrm{d}, J=11.9 \mathrm{~Hz}, 1 \mathrm{H}), 2.92-2.86(\mathrm{~m}, 3 \mathrm{H}), 2.81(\mathrm{~s}, 2 \mathrm{H}), 2.69-2.62(\mathrm{~m}, 2 \mathrm{H}), 2.59-$ $2.54(\mathrm{~m}, 1 \mathrm{H}), 2.49-2.42(\mathrm{~m}, 1 \mathrm{H}), 2.41-2.35(\mathrm{~m}, 1 \mathrm{H}), 2.23(\mathrm{~s}, 7 \mathrm{H}), 2.16-2.06(\mathrm{~m}, 1 \mathrm{H}), 2.02-1.89(\mathrm{~m}, 1 \mathrm{H}), 1.66(\mathrm{~s}, 2 \mathrm{H}), 1.64-1.59$ (m, $1 \mathrm{H}), 1.52-1.34(\mathrm{~m}, 2 \mathrm{H}), 1.30-1.22(\mathrm{~m}, 2 \mathrm{H}), 1.18(\mathrm{br} \mathrm{d}, J=5.8 \mathrm{~Hz}, 3 \mathrm{H}), 1.15-1.07(\mathrm{~m}, 16 \mathrm{H}), 1.07-1.03(\mathrm{~m}, 4 \mathrm{H}), 1.03-0.98$ $(\mathrm{m}, 6 \mathrm{H}), 0.91(\mathrm{br} \mathrm{dd}, J=14.8,6.6 \mathrm{~Hz}, 4 \mathrm{H})$.

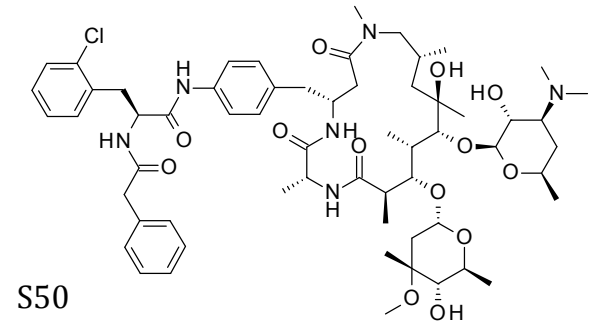

(2S)-3-(2-chlorophenyl)- $N$-[4-[[(2R,5R,10R,12R,13R,14S,15S,16R)-13-( $\beta$-Ddesosaminyl)oxy-12-hydroxy-15-( $\alpha$-L-cladinosyl)oxy-2,8,10,12,14,16hexamethyl-3,7,17-trioxo-1,4,8-triazacycloheptadec-5-yl]methyl]phenyl]-2-[(2phenylacetyl)amino]propanamide (9)

Following general procedure for Step 5: starting from $64(20.1 \mathrm{mg}, 0.063 \mathrm{mmol})$ and E-9 (52.8 mg, $0.063 \mathrm{mmol}$ ) title product was obtained (35.4 mg, yield $49.5 \%$, purity $97.2 \%$ ). Purification was performed by flash column chromatography 
with DCM:MeOH: $\mathrm{NH}_{4} \mathrm{OH}=90: 9: 1.5$ as an eluent. $\mathrm{ES}^{+} \mathrm{m} / \mathrm{z} 1135.88[\mathrm{M}+\mathrm{H}]^{+}$. Two sets of signals in the NMR (most likely conformers). ${ }^{1} \mathrm{H}$ NMR $\left(500 \mathrm{MHz}, \mathrm{DMSO}-\mathrm{d}_{6}\right) \delta / \mathrm{ppm} 9.97(\mathrm{~s}, 1 \mathrm{H}), 8.48(\mathrm{br} \mathrm{d}, J=7.6 \mathrm{~Hz}, 1 \mathrm{H}), 8.21(\mathrm{br} \mathrm{d}, J=7.6 \mathrm{~Hz}, 1 \mathrm{H}), 7.97(\mathrm{br}$ s, $1 \mathrm{H}), 7.45(\mathrm{~d}, J=8.5 \mathrm{~Hz}, 2 \mathrm{H}), 7.39$ (d, $J=7.6 \mathrm{~Hz}, 1 \mathrm{H}), 7.32-7.27(\mathrm{~m}, 1 \mathrm{H}), 7.24(\mathrm{~d}, J=7.3 \mathrm{~Hz}, 3 \mathrm{H}), 7.21-7.18(\mathrm{~m}, 2 \mathrm{H}), 7.15(\mathrm{~d}, J$ $=7.3 \mathrm{~Hz}, 2 \mathrm{H}), 7.06(\mathrm{~d}, J=8.2 \mathrm{~Hz}, 2 \mathrm{H}), 4.82-4.77(\mathrm{~m}, 2 \mathrm{H}), 4.4(\mathrm{br} \mathrm{d}, J=7.3 \mathrm{~Hz}, 1 \mathrm{H}), 4.28(\mathrm{~d}, J=8.5 \mathrm{~Hz}, 1 \mathrm{H}), 4.22-4.14(\mathrm{~m}, 1 \mathrm{H})$, 4.10-4.03 (m, 2H), 3.99 (br t, J = 7.3 Hz, 2H), 3.87 (s, 1H), 3.59 (br s, 1H), 3.49 (br d, $J=7 \mathrm{~Hz}, 2 \mathrm{H}), 3.46(\mathrm{~d}, J=9.5 \mathrm{~Hz}, 2 \mathrm{H}), 3.23$ $(\mathrm{s}, 4 \mathrm{H}), 3.16(\mathrm{br} \mathrm{d}, J=6.1 \mathrm{~Hz}, 2 \mathrm{H}), 3.10-3.01(\mathrm{~m}, 2 \mathrm{H}), 2.89(\mathrm{t}, J=8.9 \mathrm{~Hz}, 1 \mathrm{H}), 2.84-2.8(\mathrm{~m}, 1 \mathrm{H}), 2.74(\mathrm{~s}, 3 \mathrm{H}), 2.71-2.64(\mathrm{~m}, 1 \mathrm{H})$, $2.24(\mathrm{~s}, 6 \mathrm{H}), 2.05-2.02(\mathrm{~m}, 1 \mathrm{H}), 1.90-1.8(\mathrm{~m}, 1 \mathrm{H}), 1.61(\mathrm{br} \mathrm{s}, 1 \mathrm{H}), 1.48(\mathrm{br} \mathrm{dd}, J=15.0,4.6 \mathrm{~Hz}, 1 \mathrm{H}), 1.36-1.21(\mathrm{~m}, 3 \mathrm{H}), 1.19-$ $1.15(\mathrm{~m}, 7 \mathrm{H}), 1.13(\mathrm{~s}, 4 \mathrm{H}), 1.1(\mathrm{br} \mathrm{d}, J=5.8 \mathrm{~Hz}, 4 \mathrm{H}), 1.07(\mathrm{br} \mathrm{d}, J=7.3 \mathrm{~Hz}, 4 \mathrm{H}), 1.03(\mathrm{br} \mathrm{d}, J=7 \mathrm{~Hz}, 3 \mathrm{H}), 0.87(\mathrm{t}, J=6.7 \mathrm{~Hz}, 3 \mathrm{H})$, $0.8(\mathrm{br} \mathrm{d}, J=6.7 \mathrm{~Hz}, 3 \mathrm{H})$.

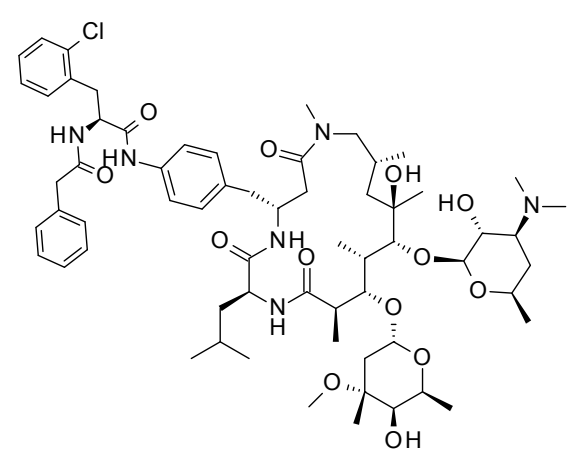

(2S)-3-(2-chlorophenyl)- $N$-[4-[[(2S,5R,10R,12R,13R,14S,15S,16R)-13-( $\beta$-Ddesosaminyl)oxy-12-hydroxy-15-( $\alpha$-L-cladinosyl)oxy-2-isobutyl-8,10, 12,14,16pentamethyl-3,7,17-trioxo-1,4,8-triazacycloheptadec-5-yl]methyl]phenyl]-2[(2-phenyl acetyl)amino]propnnamide (10)

Following general procedure for Step 5: starting from $64(61 \mathrm{mg}, 0.19 \mathrm{mmol})$ and E-10 (168 mg, $0.29 \mathrm{mmol}$ ) title product was obtained ( $40 \mathrm{mg}$, yield $12 \%$, purity $95.04 \%$ ) by prep HPLC purification. $\mathrm{ES}^{+} \mathrm{m} / \mathrm{z}=1177.79[\mathrm{M}+\mathrm{H}]^{+}{ }^{1}{ }^{1} \mathrm{H}$ NMR $(500$ MHz, DMSO-d ${ }_{6}$ ) $\delta /$ ppm $10.01($ br s, $1 \mathrm{H}), 10(\mathrm{br} \mathrm{d}, J=2.4 \mathrm{~Hz}, 1 \mathrm{H}), 8.52-8.47(\mathrm{~m}$, 2H), 8.09 (br d, $J=7.9 \mathrm{~Hz}, 1 \mathrm{H}), 7.52-7.48(\mathrm{~m}, 2 \mathrm{H}), 7.46(\mathrm{br} \mathrm{d}, J=9.2 \mathrm{~Hz}, 3 \mathrm{H}), 7.39$ (br d, J = 7.6 Hz, 2H), 7.33-7.28 (m, 3H), 7.27-7.21 (m, 7H), 7.21-7.17 (m, 4H), 7.15 (br d, $J=7.3 \mathrm{~Hz}, 5 \mathrm{H}), 7.12-7.07(\mathrm{~m}, 4 \mathrm{H}), 4.82-4.76(\mathrm{~m}, 3 \mathrm{H}), 4.58(\mathrm{br} \mathrm{d}, J=4$ $\mathrm{Hz}, 1 \mathrm{H}), 4.45(\mathrm{~d}, J=7.3 \mathrm{~Hz}, 1 \mathrm{H}), 4.41(\mathrm{br} \mathrm{d}, J=7 \mathrm{~Hz}, 1 \mathrm{H}), 4.28(\mathrm{~d}, J=7.6 \mathrm{~Hz}, 1 \mathrm{H})$, 4.21 (br d, $J=8.2 \mathrm{~Hz}, 2 \mathrm{H}), 4.16-3.99(\mathrm{~m}, 7 \mathrm{H}), 3.89(\mathrm{~s}, 1 \mathrm{H}), 3.86(\mathrm{br} \mathrm{d}, J=7.9 \mathrm{~Hz}$, $1 \mathrm{H}), 3.73-3.65(\mathrm{~m}, 1 \mathrm{H}), 3.64-3.57(\mathrm{~m}, 1 \mathrm{H}), 3.52-3.48(\mathrm{~m}, 1 \mathrm{H}), 3.45(\mathrm{~d}, J=9.8 \mathrm{~Hz}, 3 \mathrm{H}), 3.42-3.4(\mathrm{~m}, 1 \mathrm{H}), 3.21(\mathrm{~s}, 3 \mathrm{H}), 3.19(\mathrm{~s}$, $3 \mathrm{H}), 3.17-3.07(\mathrm{~m}, 6 \mathrm{H}), 3.03(\mathrm{br} \mathrm{dd}, J=14.2,9 \mathrm{~Hz}, 3 \mathrm{H}), 2.93-2.86(\mathrm{~m}, 4 \mathrm{H}), 2.81(\mathrm{~s}, 3 \mathrm{H}), 2.75-2.69(\mathrm{~m}, 2 \mathrm{H}), 2.68-2.62(\mathrm{~m}, 2 \mathrm{H})$, 2.59-2.54 (m, 1H), 2.41-2.3 (m, 3H), $2.26(\mathrm{br} \mathrm{s}, 11 \mathrm{H}), 2.21-2.15(\mathrm{~m}, 2 \mathrm{H}), 2.12-2.06(\mathrm{~m}, 2 \mathrm{H}), 2.01-1.99(\mathrm{~m}, 1 \mathrm{H}), 1.98-1.92(\mathrm{~m}$, $2 \mathrm{H}), 1.64-1.6(\mathrm{~m}, 2 \mathrm{H}), 1.52-1.39(\mathrm{~m}, 2 \mathrm{H}), 1.37-1.3(\mathrm{~m}, 2 \mathrm{H}), 1.28-1.19(\mathrm{~m}, 5 \mathrm{H}), 1.18(\mathrm{br} \mathrm{s}, 5 \mathrm{H}), 1.16-1.02(\mathrm{~m}, 32 \mathrm{H}), 1(\mathrm{br} \mathrm{d}, J=$ $7 \mathrm{~Hz}, 6 \mathrm{H}), 0.95-0.88(\mathrm{~m}, 7 \mathrm{H}), 0.80-0.7(\mathrm{~m}, 14 \mathrm{H})$.

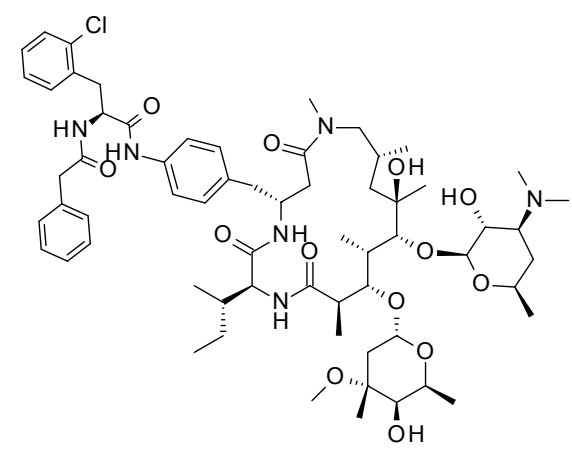

(2S)-3-(2-chlorophenyl)- $N$-[4-[[(2S,5R,10R,12R,13R,14S,15S,16R)-13-( $\beta$-Ddesosaminyl)oxy-12-hydroxy-15-( $\alpha$-L-cladinosyl)oxy-8,10,12,14,16pentamethyl-2-[(1S)-1-methylpropyl]-3,7,17-trioxo-1,4,8-triazacycloheptadec5-yl]methyl]phenyl]-2[(2phenylacetyl)amino]propanamide (11)

Following general procedure for Step 5: starting from $64(160 \mathrm{mg}, 0.5 \mathrm{mmol})$ and E-11 $(440 \mathrm{mg}, 0.5 \mathrm{mmol})$ title product was obtained $(30 \mathrm{mg}$, yield $5 \%$, purity $99.3 \%$ ) by prep HPLC purification. $\mathrm{ES}^{+} \mathrm{m} / \mathrm{z} 1177.85[\mathrm{M}+\mathrm{H}]^{+}$. Two sets of signals in the NMR (most likely conformers). ${ }^{1} \mathrm{H}$ NMR $\left(500 \mathrm{MHz}\right.$, DMSO-d $\left.\mathrm{d}_{6}\right) \delta / \mathrm{ppm} 9.99$ (s, 1H), $9.96(\mathrm{~s}, 1 \mathrm{H}), 8.52-8.44(\mathrm{~m}, 3 \mathrm{H}), 8.1(\mathrm{br} \mathrm{d}, J=8.9 \mathrm{~Hz}, 2 \mathrm{H}), 7.90-7.83(\mathrm{~m}$, $2 \mathrm{H}$ ), 7.47-7.42 (m, 3H), 7.39 (br d, $J=7.6 \mathrm{~Hz}, 2 \mathrm{H}), 7.31-7.28(\mathrm{~m}, 2 \mathrm{H}), 7.27-7.22$ (m, 6H), 7.21-7.18 (m, 4H), $7.15(\mathrm{br} \mathrm{d}, J=7.3 \mathrm{~Hz}, 4 \mathrm{H}), 7.14-7.07(\mathrm{~m}, 4 \mathrm{H}), 4.81-$ $4.76(\mathrm{~m}, 3 \mathrm{H}), 4.63-4.59(\mathrm{~m}, 1 \mathrm{H}), 4.45(\mathrm{br} \mathrm{d}, J=7 \mathrm{~Hz}, 2 \mathrm{H}), 4.37$ (br d, $J=7.3 \mathrm{~Hz}$, $2 \mathrm{H}), 4.29(\mathrm{~d}, J=7.6 \mathrm{~Hz}, 2 \mathrm{H}), 4.23(\mathrm{~d}, J=8.2 \mathrm{~Hz}, 2 \mathrm{H}), 4.14(\mathrm{br} \mathrm{s}, 2 \mathrm{H}), 4.10-4.03(\mathrm{~m}, 4 \mathrm{H}), 4.01-3.97(\mathrm{~m}, 2 \mathrm{H}), 3.85(\mathrm{br} \mathrm{d}, J=7.9$ $\mathrm{Hz}, 2 \mathrm{H}), 3.74(\mathrm{~s}, 1 \mathrm{H}), 3.64(\mathrm{br} \mathrm{dd}, J=10.4,5.8 \mathrm{~Hz}, 2 \mathrm{H}), 3.62-3.55(\mathrm{~m}, 2 \mathrm{H}), 3.54-3.49(\mathrm{~m}, 2 \mathrm{H}), 3.46(\mathrm{br} \mathrm{d}, J=7.9 \mathrm{~Hz}, 4 \mathrm{H}), 3.43-$ $3.41(\mathrm{~m}, 2 \mathrm{H}), 3.21(\mathrm{~s}, 4 \mathrm{H}), 3.19(\mathrm{~s}, 2 \mathrm{H}), 3.17-3.1(\mathrm{~m}, 3 \mathrm{H}), 3.10-2.99(\mathrm{~m}, 6 \mathrm{H}), 2.93-2.86(\mathrm{~m}, 3 \mathrm{H}), 2.8(\mathrm{~s}, 4 \mathrm{H}), 2.70-2.55(\mathrm{~m}, 7 \mathrm{H})$, $2.49-2.43(\mathrm{~m}, 3 \mathrm{H}), 2.41-2.33(\mathrm{~m}, 2 \mathrm{H}), 2.29(\mathrm{br} \mathrm{d}, J=15.3 \mathrm{~Hz}, 2 \mathrm{H}), 2.27-2.22(\mathrm{~m}, 12 \mathrm{H}), 2.16-2.05(\mathrm{~m}, 2 \mathrm{H}), 1.96(\mathrm{br} \mathrm{t}, J=6.9 \mathrm{~Hz}$, $2 \mathrm{H}), 1.83-1.75(\mathrm{~m}, 1 \mathrm{H}), 1.63-1.54(\mathrm{~m}, 2 \mathrm{H}), 1.51-1.45(\mathrm{~m}, 3 \mathrm{H}), 1.24(\mathrm{br} \mathrm{s}, 4 \mathrm{H}), 1.21-1.04(\mathrm{~m}, 29 \mathrm{H}), 0.99(\mathrm{br} \mathrm{d}, J=7 \mathrm{~Hz}, 5 \mathrm{H})$, 0.96-0.84 (m, 6H), $0.72(\mathrm{br} \mathrm{t}, J=7.2 \mathrm{~Hz}, 3 \mathrm{H}), 0.64-0.62(\mathrm{~m}, 6 \mathrm{H}), 0.47(\mathrm{br} \mathrm{d}, J=6.7 \mathrm{~Hz}, 3 \mathrm{H})$.

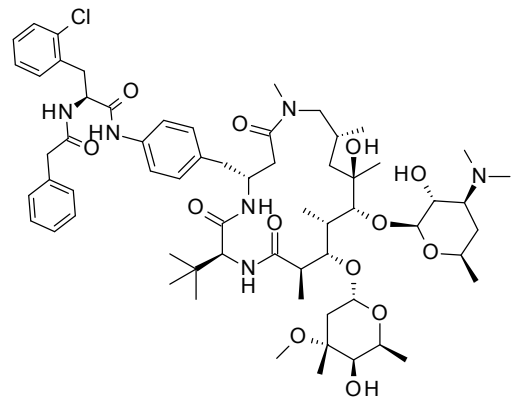

(2S)- $N$-[4-[[(2S,5R,10R,12R,13R,14S,15S,16R)-2-tert-butyl-13-( $\beta$-Ddesosaminyl)oxy-12-hydroxy-15-( $\alpha$-L-cladinosyl)oxy-8,10,12,14,16-pentamethyl3,7,17-trioxo-1,4,8-triazacyclo heptadec-5-yl]methyl]phenyl]-3-(2-chloro phenyl)-2[(2-phenylacetyl)amino]propanamide (12)

Following general procedure for Step 5: starting from $64(31.3 \mathrm{mg}, 0.099 \mathrm{mmol})$ and E-12 (86.5 mg, $0.099 \mathrm{mmol}$ ) title product was obtained (60.9 $\mathrm{mg}$, yield $52.2 \%$, purity $92.6 \%$ ). Purification was performed by flash column chromatography with DCM:MeOH: $\mathrm{NH}_{4} \mathrm{OH}=90: 9: 1.5$ as an eluent. $\mathrm{ES}^{+} \mathrm{m} / \mathrm{z} 1177.83[\mathrm{M}+\mathrm{H}]^{+}$. Two sets of signals in the NMR (most likely conformers). ${ }^{1} \mathrm{H}$ NMR $\left(500 \mathrm{MHz}\right.$, DMSO- $\left.\mathrm{d}_{6}\right) \delta / \mathrm{ppm}$ $9.97(\mathrm{~s}, 1 \mathrm{H}), 9.94(\mathrm{~d}, J=2.7 \mathrm{~Hz}, 1 \mathrm{H}), 8.50-8.46(\mathrm{~m}, 3 \mathrm{H}), 8.1(\mathrm{br} \mathrm{d}, J=8.9 \mathrm{~Hz}, 2 \mathrm{H}), 7.78$ (br d, $J=9.2 \mathrm{~Hz}, 2 \mathrm{H}), 7.47-7.41(\mathrm{~m}, 4 \mathrm{H}), 7.39(\mathrm{~d}, J=7.6 \mathrm{~Hz}, 2 \mathrm{H}), 7.32-7.11(\mathrm{~m}, 18 \mathrm{H})$, $6.95(\mathrm{br} \mathrm{d}, J=8.5 \mathrm{~Hz}, 2 \mathrm{H}), 4.86(\mathrm{br} \mathrm{d}, J=4.6 \mathrm{~Hz}, 2 \mathrm{H}), 4.82-4.75(\mathrm{~m}, 3 \mathrm{H}), 4.7(\mathrm{br} \mathrm{d}, J=4.6 \mathrm{~Hz}, 2 \mathrm{H}), 4.47(\mathrm{~d}, J=7 \mathrm{~Hz}, 2 \mathrm{H}), 4.35(\mathrm{br}$ d, $J=7.3 \mathrm{~Hz}, 2 \mathrm{H}), 4.32$ (d, $J=7.9 \mathrm{~Hz}, 2 \mathrm{H}), 4.23(\mathrm{br} \mathrm{d}, J=8.5 \mathrm{~Hz}, 2 \mathrm{H}), 4.15(\mathrm{br} \mathrm{d}, J=8.5 \mathrm{~Hz}, 2 \mathrm{H}), 4.11$ (br s, 2H), $4.09-4.02(\mathrm{~m}$, 
2H), 3.9 (br d, J = 7.6 Hz, 2H), $3.85(\mathrm{~s}, 1 \mathrm{H}), 3.70-3.61(\mathrm{~m}, 5 \mathrm{H}), 3.59-3.38(\mathrm{~m}, 6 \mathrm{H}), 3.23-3.15(\mathrm{~m}, 6 \mathrm{H}), 3.13-3.01(\mathrm{~m}, 6 \mathrm{H}), 2.99-$ $2.86(\mathrm{~m}, 5 \mathrm{H}), 2.84(\mathrm{~s}, 3 \mathrm{H}), 2.76(\mathrm{~s}, 6 \mathrm{H}), 2.71-2.53(\mathrm{~m}, 6 \mathrm{H}), 2.40-2.35(\mathrm{~m}, 1 \mathrm{H}), 2.31-2.2(\mathrm{~m}, 13 \mathrm{H}), 2.18-2.03(\mathrm{~m}, 4 \mathrm{H}), 1.62(\mathrm{br}$ $\mathrm{d}, J=11 \mathrm{~Hz}, 2 \mathrm{H}), 1.54-1.38(\mathrm{~m}, 2 \mathrm{H}), 1.25-1.07(\mathrm{~m}, 32 \mathrm{H}), 1.01(\mathrm{br} \mathrm{d}, J=7.3 \mathrm{~Hz}, 6 \mathrm{H}), 0.98-0.88(\mathrm{~m}, 6 \mathrm{H}), 0.82(\mathrm{~s}, 4 \mathrm{H}), 0.62(\mathrm{~s}$, $12 \mathrm{H})$.

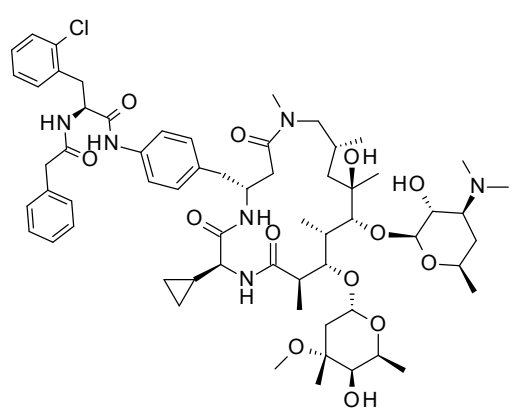

(2S)-3-(2-chlorophenyl)- $N$-[4-[[(2S,5R,10R,12R,13R,14S,15S,16R)-2-cyclopropyl-13( $\beta$-D-desosaminyl)oxy-12-hydroxy-15-( $\alpha$-L-cladinosyl)oxy-8,10,12,14,16-

pentamethyl-3,7,17-trioxo-1,4,8-triazacycloheptadec-5-yl]methyl]phenyl]-2-[(2phenylacetyl)amino]propanamide (13)

Following general procedure for Step 5: starting from $64(28.6 \mathrm{mg}, 0.09 \mathrm{mmol})$ and E-13 $(77.7 \mathrm{mg}, 0.09 \mathrm{mmol})$ title product was obtained as a beige solid $(29.8 \mathrm{mg}$, yield $28.5 \%$, purity $94.8 \%$.). Purification was performed by flash column chromatography with DCM:MeOH: $\mathrm{NH}_{4} \mathrm{OH}=$ 90:9:1.5 as an eluent. $\mathrm{ES}^{+} \mathrm{m} / \mathrm{z} 1161.89[\mathrm{M}+\mathrm{H}]^{+}$. Two sets of signals in the NMR (most likely conformers). ${ }^{1} \mathrm{H}$ NMR (500 MHz, DMSO-d $\left.\mathrm{d}_{6}\right) \delta / \mathrm{ppm}$ $10.02(\mathrm{~s}, 1 \mathrm{H}), 9.98(\mathrm{~s}, 1 \mathrm{H}), 8.48(\mathrm{~s}, 2 \mathrm{H}), 7.96(\mathrm{br} \mathrm{d}, J=8.5 \mathrm{~Hz}, 1 \mathrm{H}), 7.9(\mathrm{br} \mathrm{d}, J=9.2 \mathrm{~Hz}$, $1 \mathrm{H}), 7.64(\mathrm{br} \mathrm{d}, J=6.4 \mathrm{~Hz}, 1 \mathrm{H}), 7.62-7.55(\mathrm{~m}, 1 \mathrm{H}), 7.48-7.43(\mathrm{~m}, 3 \mathrm{H}), 7.39$ (d, $J=7.7$ $\mathrm{Hz}, 2 \mathrm{H}), 7.32-7.29(\mathrm{~m}, 2 \mathrm{H}), 7.27-7.06(\mathrm{~m}, 19 \mathrm{H}), 4.83-4.74(\mathrm{~m}, 3 \mathrm{H}), 4.69-4.64(\mathrm{~m}, 1 \mathrm{H})$, 4.45 (br d, $J=7 \mathrm{~Hz}, 1 \mathrm{H}), 4.42$ (br d, $J=7.3 \mathrm{~Hz}, 1 \mathrm{H}), 4.29$ (d, $J=7.9 \mathrm{~Hz}, 1 \mathrm{H}), 4.23(\mathrm{br} \mathrm{d}, J=8.2 \mathrm{~Hz}, 1 \mathrm{H}), 4.09-3.96(\mathrm{~m}, 4 \mathrm{H}), 3.88$ (br d, $J=8.2 \mathrm{~Hz}, 1 \mathrm{H}), 3.86(\mathrm{~s}, 1 \mathrm{H}), 3.72-3.59(\mathrm{~m}, 2 \mathrm{H}), 3.57-3.4(\mathrm{~m}, 10 \mathrm{H}), 3.25-3.11(\mathrm{~m}, 11 \mathrm{H}), 3.10-2.97(\mathrm{~m}, 5 \mathrm{H}), 2.96-2.85(\mathrm{~m}$, $4 \mathrm{H}), 2.81(\mathrm{~s}, 4 \mathrm{H}), 2.80-2.63(\mathrm{~m}, 6 \mathrm{H}), 2.61-2.53(\mathrm{~m}, 2 \mathrm{H}), 2.39$ (br s, 12H), 2.30-2.2 (m, 4H), 2.16-2.03 (m, 3H), 2.01-1.9 (m, $3 \mathrm{H}), 1.80-1.77(\mathrm{~m}, 1 \mathrm{H}), 1.77-1.64(\mathrm{~m}, 2 \mathrm{H}), 1.5(\mathrm{br} \mathrm{dd}, J=14.6,4.6 \mathrm{~Hz}, 2 \mathrm{H}), 1.46-1.36(\mathrm{~m}, 1 \mathrm{H}), 1.33-1.22(\mathrm{~m}, 4 \mathrm{H}), 1.21-1.07$ $(\mathrm{m}, 33 \mathrm{H}), 1.06-0.96(\mathrm{~m}, 9 \mathrm{H}), 0.95-0.82(\mathrm{~m}, 10 \mathrm{H}), 0.34-0.22(\mathrm{~m}, 5 \mathrm{H}), 0.22-0.14(\mathrm{~m}, 3 \mathrm{H}), 0.13-0.06(\mathrm{~m}, 3 \mathrm{H})$.

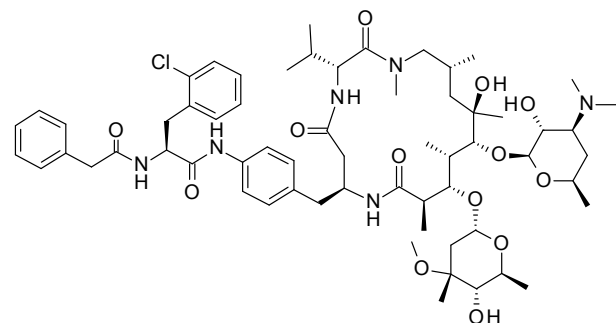
1H), 7.34-7.28 (m, 1H), 7.26-7.21 (m, 3H), 7.20-7.16 (m, 4H), 7.15-7.11 (m, 3H), 4.82-4.74 (m, 1H), 4.60-4.55 (m, 1H), 4.52 (br t, $J=5.5 \mathrm{~Hz}, 1 \mathrm{H}), 4.36(\mathrm{~d}, J=7.3 \mathrm{~Hz}, 1 \mathrm{H}), 4.17-4.11(\mathrm{~m}, 1 \mathrm{H}), 4.10-4.05(\mathrm{~m}, 2 \mathrm{H}), 4.04(\mathrm{br} \mathrm{dd}, J=7.9,2.7 \mathrm{~Hz}, 1 \mathrm{H}), 3.98(\mathrm{br} \mathrm{s}$, 1H), 3.63 (br s, 1H), 3.49-3.4 (m, 3H), 3.21 (s, 3H), 3.20-3.17 (m, 2H), $3.16(\mathrm{~s}, 3 \mathrm{H}), 3.10-2.99(\mathrm{~m}, 3 \mathrm{H}), 2.93-2.86(\mathrm{~m}, 1 \mathrm{H}), 2.69$ (br s, 1H), 2.48-2.43 (m, 3H), 2.44-2.38 (m, 1H), 2.25-2.22 (m, 2H), $2.2(\mathrm{~s}, 6 \mathrm{H}), 2.15(\mathrm{br} \mathrm{s}, 2 \mathrm{H}), 2.07-2.02(\mathrm{~m}, 1 \mathrm{H}), 1.97(\mathrm{br} \mathrm{d}$, $J=11.3 \mathrm{~Hz}, 1 \mathrm{H}), 1.61-1.55(\mathrm{~m}, 1 \mathrm{H}), 1.41(\mathrm{br} \mathrm{dd}, J=14.8,4.7 \mathrm{~Hz}, 1 \mathrm{H}), 1.18-1.14(\mathrm{~m}, 6 \mathrm{H}), 1.12(\mathrm{~s}, 2 \mathrm{H}), 1.08(\mathrm{br} \mathrm{d}, J=6.1 \mathrm{~Hz}, 4 \mathrm{H})$, 1.04-1 (m, 4H), 0.98 (br d, $J=7$ Hz, 8H), 0.96 (br s, 3H), 0.92 (br d, $J=7$ Hz, 3H), 0.84 (br t, $J=7.5$ Hz, $1 \mathrm{H}$ )

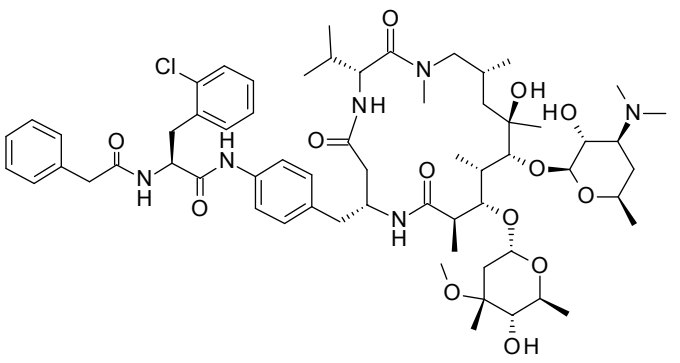

(2S)-3-(2-chlorophenyl)- $N$-[4-[[(3R,7R,10R,11S,12S,13R,14R,16R)-13-( $\beta$ D-desosaminyl)oxy-14-hydroxy-11-( $\alpha$-L-cladinosyl)oxy-3-isopropyl1,10,12,14,16-pentamethyl-2,5,9-trioxo-1,4,8-triazacycloheptadec-7yl]methyl]phenyl]-2-[(2-phenylacetyl)amino]propanamide (15) Following general procedure for Step 5: starting from $64(28 \mathrm{mg}, 0.089$ $\mathrm{mmol})$ and $\mathbf{E}-\mathbf{1 5}(70 \mathrm{mg}, 0.081 \mathrm{mmol})$ title product was obtained $(10 \mathrm{mg}$, yield $10 \%$, purity $97.9 \%$ ) by prep HPLC purification. $\mathrm{ES}^{+} \mathrm{m} / \mathrm{z} 1163.54$ $[\mathrm{M}+\mathrm{H}]^{+} .{ }^{1} \mathrm{H}$ NMR $\left(600 \mathrm{MHz}, \mathrm{DMSO}-\mathrm{d}_{6}\right) \delta / \mathrm{ppm} 10.02(\mathrm{~s}, 1 \mathrm{H}), 9.96(\mathrm{~s}, 1 \mathrm{H})$, 8.52-8.43 (m, 3H), 8.09 (br d, $J=8.3 \mathrm{~Hz}, 2 \mathrm{H}), 7.52-7.47(\mathrm{~m}, 4 \mathrm{H}), 7.44(\mathrm{br}$ $\mathrm{d}, J=8.3 \mathrm{~Hz}, 2 \mathrm{H}), 7.40-7.35(\mathrm{~m}, 2 \mathrm{H}), 7.3(\mathrm{dd}, J=7.5,1.8 \mathrm{~Hz}, 2 \mathrm{H}), 7.28(\mathrm{dd}, J$ $=7.4,1.7 \mathrm{~Hz}, 2 \mathrm{H}), 7.24-7.2(\mathrm{~m}, 5 \mathrm{H}), 7.20-7.15(\mathrm{~m}, 3 \mathrm{H}), 7.14-7.1(\mathrm{~m}, 3 \mathrm{H}), 7.04(\mathrm{~d}, J=8.4 \mathrm{~Hz}, 4 \mathrm{H}), 4.88(\mathrm{br} \mathrm{d}, J=3.9 \mathrm{~Hz}, 2 \mathrm{H})$, $4.80-4.73(\mathrm{~m}, 2 \mathrm{H}), 4.58(\mathrm{br} \mathrm{s}, 2 \mathrm{H}), 4.46(\mathrm{br} \mathrm{d}, J=7 \mathrm{~Hz}, 2 \mathrm{H}), 4.35(\mathrm{br} \mathrm{d}, J=7.3 \mathrm{~Hz}, 2 \mathrm{H}), 4.32-4.27(\mathrm{~m}, 2 \mathrm{H}), 4.22(\mathrm{br} \mathrm{d}, J=7.3 \mathrm{~Hz}$, 2H), 4.17 (br s, 2H), $4.1(\mathrm{br} \mathrm{d}, J=5 \mathrm{~Hz}, 2 \mathrm{H}), 4.05(\mathrm{~d}, J=8.4 \mathrm{~Hz}, 2 \mathrm{H}), 4.03-3.96(\mathrm{~m}, 2 \mathrm{H}), 3.76-3.59(\mathrm{~m}, 6 \mathrm{H}), 3.49-3.4(\mathrm{~m}, 4 \mathrm{H})$, $3.38-3.36(\mathrm{~m}, 2 \mathrm{H}), 3.23$ (br s, 2H), 3.18-3.12 (m, 8H), 3.02 (dd, J= 14.1, $9 \mathrm{~Hz}, 3 \mathrm{H}), 2.96(\mathrm{~s}, 3 \mathrm{H}), 2.92-2.87(\mathrm{~m}, 1 \mathrm{H}), 2.84(\mathrm{br} \mathrm{t}, J$ $=9 \mathrm{~Hz}, 2 \mathrm{H}), 2.74(\mathrm{~s}, 3 \mathrm{H}), 2.70-2.58(\mathrm{~m}, 4 \mathrm{H}), 2.58-2.52(\mathrm{~m}, 4 \mathrm{H}), 2.41-2.28(\mathrm{~m}, 12 \mathrm{H}), 2.22(\mathrm{br} \mathrm{d}, J=15.2 \mathrm{~Hz}, 2 \mathrm{H}), 2.12-2.04(\mathrm{~m}$, 6H), 2-1.9 (m, 3H), 1.83 (br s, 1H), 1.76 (br s, 2H), 1.68 (br s, 2H), 1.43 (br dd, $J=14.8,4.9 \mathrm{~Hz}, 2 \mathrm{H}$ ), 1.37 (br dd, $J=14.8,4.3$ $\mathrm{Hz}, 2 \mathrm{H}), 1.25-1.15(\mathrm{~m}, 3 \mathrm{H}), 1.14-1.03(\mathrm{~m}, 25 \mathrm{H}), 1(\mathrm{br} \mathrm{d}, J=7.2 \mathrm{~Hz}, 3 \mathrm{H}), 0.93(\mathrm{br} \mathrm{d}, J=6.8 \mathrm{~Hz}, 4 \mathrm{H}), 0.89$ (br d, $J=6.6 \mathrm{~Hz}, 3 \mathrm{H}$ ), $0.84(\mathrm{~d}, J=6.6 \mathrm{~Hz}, 3 \mathrm{H}), 0.8(\mathrm{br} \mathrm{d}, J=6.8 \mathrm{~Hz}, 3 \mathrm{H}), 0.76(\mathrm{dd}, J=6.3,3.9 \mathrm{~Hz}, 6 \mathrm{H})$.

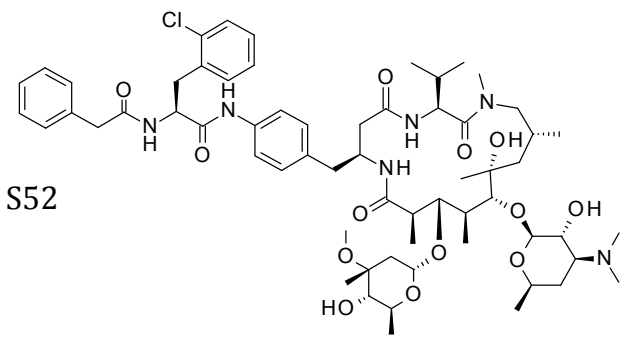

(2S)-3-(2-chlorophenyl)- $N$-[4-[[(3S,7S,10R,11S,12S,13R,14R,16R)-13-( $\beta$-Ddesosaminyl)oxy-14-hydroxy-11-( $\alpha$-L-cladinosyl)oxy-3-isopropyl1,10,12,14,16-pentamethyl-2,5,9-trioxo-1,4,8-triazacycloheptadec-7yl]methyl]phenyl]-2-[(2-phenylacetyl)amino]propanamide (16) 
Following general procedure for Step 5: starting from $64(40 \mathrm{mg}, 0.127 \mathrm{mmol})$ and E-16 (100 $\mathrm{mg}, 0.116 \mathrm{mmol})$ title product was obtained (55 mg, yield $41 \%$, purity $98.5 \%$ ) by prep HPLC purification. ES ${ }^{+} \mathrm{m} / \mathrm{z} 1163.46[\mathrm{M}+\mathrm{H}]^{+} .{ }^{1} \mathrm{H} \mathrm{NMR}(600 \mathrm{MHz}$, DMSO-d $\left.\mathrm{d}_{6}\right) \delta / \mathrm{ppm} 10.02-9.98(\mathrm{~m}, 1 \mathrm{H}), 8.53-8.49(\mathrm{~m}, 1 \mathrm{H}), 8.40-8.36(\mathrm{~m}, 1 \mathrm{H}), 7.97-7.93(\mathrm{~m}, 1 \mathrm{H}), 7.83-7.79(\mathrm{~m}, 1 \mathrm{H}), 7.49-7.45$ $(\mathrm{m}, 2 \mathrm{H}), 7.38(\mathrm{~d}, J=7.9 \mathrm{~Hz}, 1 \mathrm{H}), 7.32-7.29(\mathrm{~m}, 1 \mathrm{H}), 7.24-7.11(\mathrm{~m}, 8 \mathrm{H}), 7(\mathrm{br} \mathrm{d}, J=6.8 \mathrm{~Hz}, 1 \mathrm{H}), 4.80-4.74(\mathrm{~m}, 1 \mathrm{H}), 4.48-4.43$ (m, 2H), $4.27(\mathrm{br} \mathrm{t}, J=8.4 \mathrm{~Hz}, 1 \mathrm{H}), 4.17-4.12(\mathrm{~m}, 1 \mathrm{H}), 4.06-4(\mathrm{~m}, 2 \mathrm{H}), 3.9(\mathrm{~s}, 1 \mathrm{H}), 3.81(\mathrm{br} \mathrm{s}, 1 \mathrm{H}), 3.70-3.64(\mathrm{~m}, 1 \mathrm{H}), 3.62-3.57$ (m, 1H), 3.47-3.42 (m, 2H), $3.37(\mathrm{br} \mathrm{d}, J=6.6 \mathrm{~Hz}, 1 \mathrm{H}), 3.22(\mathrm{~s}, 2 \mathrm{H}), 3.21-3.13(\mathrm{~m}, 3 \mathrm{H}), 3.08-3.01(\mathrm{~m}, 3 \mathrm{H}), 2.96-2.91(\mathrm{~m}, 1 \mathrm{H})$, $2.88(\mathrm{dd}, J=9.1,7.8 \mathrm{~Hz}, 1 \mathrm{H}), 2.79(\mathrm{~d}, J=1.7 \mathrm{~Hz}, 2 \mathrm{H}), 2.59-2.54(\mathrm{~m}, 1 \mathrm{H}), 2.43(\mathrm{br} \mathrm{d}, J=8.3 \mathrm{~Hz}, 1 \mathrm{H}), 2.39-2.36(\mathrm{~m}, 1 \mathrm{H}), 2.26(\mathrm{br}$ $\mathrm{d}, J=15 \mathrm{~Hz}, 1 \mathrm{H}), 2.22(\mathrm{~s}, 6 \mathrm{H}), 2.14(\mathrm{br} \mathrm{d}, J=14.7 \mathrm{~Hz}, 2 \mathrm{H}), 2.06(\mathrm{~s}, 2 \mathrm{H}), 1.99-1.93(\mathrm{~m}, 1 \mathrm{H}), 1.63-1.55(\mathrm{~m}, 1 \mathrm{H}), 1.45(\mathrm{br} \mathrm{dd}, J=$ 14.7, $4.8 \mathrm{~Hz}, 1 \mathrm{H}), 1.33-1.26(\mathrm{~m}, 1 \mathrm{H}), 1.24-1.21(\mathrm{~m}, 1 \mathrm{H}), 1.18-1.15(\mathrm{~m}, 3 \mathrm{H}), 1.14-1.11(\mathrm{~m}, 5 \mathrm{H}), 1.09(\mathrm{~s}, 2 \mathrm{H}), 1.06(\mathrm{~d}, J=5.9 \mathrm{~Hz}$, $3 \mathrm{H}), 1.03$ (br d, $J=7.3 \mathrm{~Hz}, 1 \mathrm{H}), 0.98-0.92(\mathrm{~m}, 5 \mathrm{H}), 0.90-0.85(\mathrm{~m}, 3 \mathrm{H}), 0.81-0.74(\mathrm{~m}, 6 \mathrm{H})$.

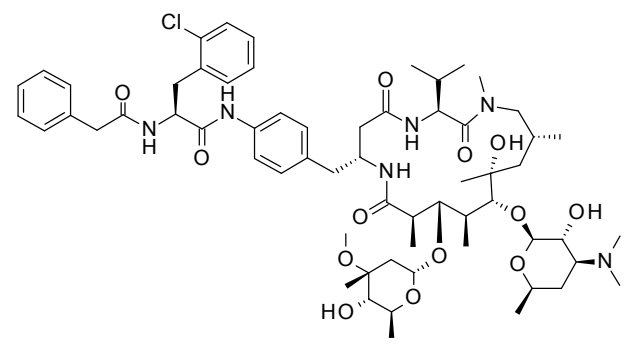

(2S)-3-(2-chlorophenyl)- $N$-[4-[[(3S,7R,10R,11S,12S,13R,14R,16R)-13-( $\beta$-Ddesosaminyl)oxy-14-hydroxy-11-( $\alpha$-L-cladinosyl)oxy-3-isopropyl1,10,12,14,16-pentamethyl-2,5,9-trioxo-1,4,8-triazacycloheptadec-7yl]methyl]phenyl]-2-[(2-phenylacetyl)amino]propanamide (17) Following general procedure for Step 5: starting from $64(40 \mathrm{mg}, 0.127 \mathrm{mmol})$ and E-17 (100 mg, $0.116 \mathrm{mmol}$ ) title product was obtained (60 $\mathrm{mg}$, yield 44 $\%$, purity $97 \%$ ) by prep HPLC purification. ES $+\mathrm{m} / \mathrm{z} 1163.72[\mathrm{M}+\mathrm{H}]^{+} .{ }^{1} \mathrm{H}$ NMR (500 MHz, DMSO-d 6 ) $\delta / p p m ~ 9.99(\mathrm{~s}, 1 \mathrm{H}), 8.52-8.44(\mathrm{~m}, 1 \mathrm{H}), 8.25-8.17(\mathrm{~m}$, $1 \mathrm{H}), 7.89(\mathrm{br} \mathrm{d}, J=9.2 \mathrm{~Hz}, 1 \mathrm{H}), 7.45(\mathrm{~d}, J=8.5 \mathrm{~Hz}, 2 \mathrm{H}), 7.39(\mathrm{~d}, J=7.9 \mathrm{~Hz}, 1 \mathrm{H})$, 7.29 (br d, $J=7.3 \mathrm{~Hz}, 1 \mathrm{H}), 7.27-7.22(\mathrm{~m}, 3 \mathrm{H}), 7.22-7.17(\mathrm{~m}, 2 \mathrm{H}), 7.15(\mathrm{br} \mathrm{d}, J=$ $7.3 \mathrm{~Hz}, 2 \mathrm{H}), 7.06(\mathrm{~d}, J=8.2 \mathrm{~Hz}, 2 \mathrm{H}), 4.84-4.71(\mathrm{~m}, 2 \mathrm{H}), 4.44-4.34(\mathrm{~m}, 2 \mathrm{H}), 4.32-4.21(\mathrm{~m}, 2 \mathrm{H}), 4.17-4.09(\mathrm{~m}, 1 \mathrm{H}), 4.08-3.98(\mathrm{~m}$, $1 \mathrm{H}), 3.89-3.8(\mathrm{~m}, 2 \mathrm{H}), 3.66-3.55(\mathrm{~m}, 1 \mathrm{H}), 3.52-3.39(\mathrm{~m}, 4 \mathrm{H}), 3.21-3.14(\mathrm{~m}, 5 \mathrm{H}), 3.13-2.99(\mathrm{~m}, 3 \mathrm{H}), 2.91-2.83(\mathrm{~m}, 1 \mathrm{H}), 2.81-$ $2.71(\mathrm{~m}, 4 \mathrm{H}), 2.23(\mathrm{~s}, 6 \mathrm{H}), 2.21-2.16(\mathrm{~m}, 1 \mathrm{H}), 2.11-1.91(\mathrm{~m}, 3 \mathrm{H}), 1.80-1.71(\mathrm{~m}, 1 \mathrm{H}), 1.61(\mathrm{br} \mathrm{d}, J=10.7 \mathrm{~Hz}, 1 \mathrm{H}), 1.43(\mathrm{br} d \mathrm{dd}, J$ $=15.0,4.6 \mathrm{~Hz}, 1 \mathrm{H}), 1.39-1.32(\mathrm{~m}, 1 \mathrm{H}), 1.32-1.19(\mathrm{~m}, 2 \mathrm{H}), 1.16-1.08(\mathrm{~m}, 13 \mathrm{H}), 1(\mathrm{br} \mathrm{d}, J=7.3 \mathrm{~Hz}, 3 \mathrm{H}), 0.88-0.79(\mathrm{~m}, 9 \mathrm{H}), 0.64$ (br s, 2H).

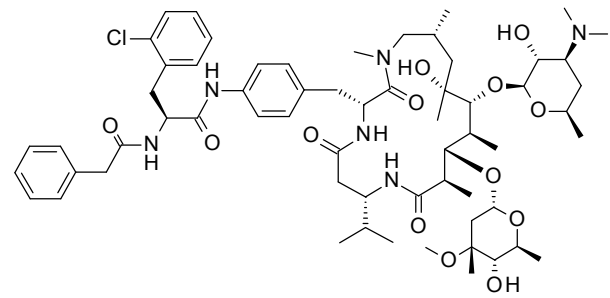

(2S)-3-(2-chlorophenyl)- $N$-[4-[[(3R,7S,10R,11S,12S,13R,14R,16R)-13-( $\beta$-Ddesosaminyl)oxy-14-hydroxy-11-( $\alpha$-L-cladinosyl)oxy-7-isopropyl1,10,12,14,16-pentamethyl-2,5,9-trioxo-1,4,8-triazacycloheptadec-3yl]methyl]phenyl]-2-[(2-phenylacetyl)amino]propanamide (18) Following general procedure for Step 5: starting from 64 (38.6 mg, 0.122 mmol) and E-18 (100 $\mathrm{mg}, 0.116 \mathrm{mmol})$ title product was obtained as a yellowish solid foam (73.8 mg, yield $54.7 \%$, purity $91.6 \%$ ). Purification was performed by flash column chromatography with $\mathrm{DCM}: \mathrm{MeOH}: \mathrm{NH}_{4} \mathrm{OH}=$ 90:9:1.5 as an eluent. $\mathrm{ES}^{+} \mathrm{m} / \mathrm{z} 1163.52 / 1165.44[\mathrm{M}+\mathrm{H}]^{+}$. Two sets of signals in the NMR (most likely conformers). ${ }^{1} \mathrm{H}$ NMR $\left(500 \mathrm{MHz}, \mathrm{DMSO}-\mathrm{d}_{6}\right) \delta / \mathrm{ppm} 10.01(\mathrm{~s}, 1 \mathrm{H}), 9.98-9.94(\mathrm{~m}, 1 \mathrm{H}), 8.49$ (dd, $J=17.5$, $8.4 \mathrm{~Hz}, 2 \mathrm{H}), 8.21(\mathrm{br} \mathrm{d}, J=7.9 \mathrm{~Hz}, 1 \mathrm{H}), 7.62(\mathrm{br} \mathrm{d}, J=7.9 \mathrm{~Hz}, 1 \mathrm{H}), 7.47-7.38(\mathrm{~m}, 8 \mathrm{H}), 7.31(\mathrm{t}, J=7.9 \mathrm{~Hz}, 3 \mathrm{H}), 7.27-7.22(\mathrm{~m}, 7 \mathrm{H})$, 7.21-7.18 (m, 4H), 7.18-7.14 (m, 7H), $7.03(\mathrm{~d}, J=8.2 \mathrm{~Hz}, 2 \mathrm{H}), 5.06(\mathrm{br} \mathrm{d}, J=3.7 \mathrm{~Hz}, 1 \mathrm{H}), 4.95-4.89(\mathrm{~m}, 2 \mathrm{H}), 4.82-4.75(\mathrm{~m}, 2 \mathrm{H})$, 4.65 (br s, 1H), 4.49 (br d, $J=7.3 \mathrm{~Hz}, 1 \mathrm{H}), 4.35(\mathrm{~d}, J=7.3 \mathrm{~Hz}, 1 \mathrm{H}), 4.25-4.16(\mathrm{~m}, 2 \mathrm{H}), 4.11(\mathrm{~d}, J=8.5 \mathrm{~Hz}, 2 \mathrm{H}), 4.03(\mathrm{br} \mathrm{d}, J=6.1$ $\mathrm{Hz}, 2 \mathrm{H}), 3.91-3.85(\mathrm{~m}, 2 \mathrm{H}), 3.82(\mathrm{br} \mathrm{d}, J=6.1 \mathrm{~Hz}, 1 \mathrm{H}), 3.74(\mathrm{br} \mathrm{s}, 2 \mathrm{H}), 3.69-3.61(\mathrm{~m}, 1 \mathrm{H}), 3.48-3.44(\mathrm{~m}, 4 \mathrm{H}), 3.24(\mathrm{~s}, 3 \mathrm{H}), 3.18$ (s, 5H), 3.11-3 (m, 4H), 2.97-2.89 (m, 3H), $2.87(\mathrm{~s}, 3 \mathrm{H}), 2.85-2.81(\mathrm{~m}, 2 \mathrm{H}), 2.74-2.71(\mathrm{~m}, 4 \mathrm{H}), 2.49-2.41(\mathrm{~m}, 4 \mathrm{H}), 2.24(\mathrm{~d}, J=$ $4.3 \mathrm{~Hz}, 13 \mathrm{H}), 2.12(\mathrm{br} \mathrm{d}, J=15.3 \mathrm{~Hz}, 3 \mathrm{H}), 2.02(\mathrm{br} \mathrm{d}, J=11 \mathrm{~Hz}, 2 \mathrm{H}), 1.93-1.81(\mathrm{~m}, 2 \mathrm{H}), 1.76-1.7(\mathrm{~m}, 1 \mathrm{H}), 1.68-1.58(\mathrm{~m}, 4 \mathrm{H})$, 1.55 (br s, 1H), 1.46 (br dd, $J=14.5,4.7 \mathrm{~Hz}, 1 \mathrm{H}), 1.35$ (br dd, $J=15.0,4.6 \mathrm{~Hz}, 1 \mathrm{H}), 1.16-1.13(\mathrm{~m}, 8 \mathrm{H}), 1.12(\mathrm{~s}, 9 \mathrm{H}), 1.10-1.07$ (m, 10H), 1.03 (br d, $J=7 \mathrm{~Hz}, 6 \mathrm{H}), 0.99$ (br d, $J=7 \mathrm{~Hz}, 4 \mathrm{H}), 0.95$ (br dd, $J=6.4,3.7 \mathrm{~Hz}, 10 \mathrm{H}), 0.78$ (dd, $J=6.9,3.2 \mathrm{~Hz}, 8 \mathrm{H}), 0.76-$ $0.71(\mathrm{~m}, 7 \mathrm{H}), 0.69(\mathrm{br} \mathrm{d}, J=5.5 \mathrm{~Hz}, 3 \mathrm{H})$.

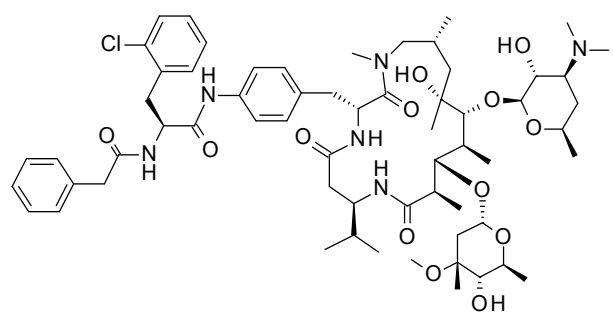

(2S)-3-(2-chlorophenyl)- $N$-[4-[[(3R,7R,10R,11S,12S,13R,14R,16R)-13-( $\beta$-Ddesosaminyl)oxy-14-hydroxy-11-( $\alpha$-L-cladinosyl)oxy-7-isopropyl1,10,12,14,16-pentamethyl-2,5,9-trioxo-1,4,8-triazacycloheptadec-3yl]methyl]phenyl]-2-[(2-phenylacetyl)amino]propanamide (19)

Following general procedure for Step 5: starting from $64(22 \mathrm{mg}, 0.07 \mathrm{mmol})$ and E-19 (60 mg, $0.07 \mathrm{mmol}$ ) title product (14 mg, yield $17 \%$, purity $90.94 \%$ ) was obtained by prep HPLC purification. $\mathrm{ES}^{+} \mathrm{m} / \mathrm{z} 1163.45[\mathrm{M}+\mathrm{H}]^{+}$. Two sets of signals in the NMR (most likely conformers). ${ }^{1} \mathrm{H}$ NMR $\left(500 \mathrm{MHz}\right.$, DMSO- $\mathrm{d}_{6}$ ) $\delta / \mathrm{ppm} 10.04(\mathrm{~s}, 1 \mathrm{H}), 9.99$ (d, $J=9.2 \mathrm{~Hz}, 1 \mathrm{H}), 8.63(\mathrm{br} \mathrm{d}, J=9.5 \mathrm{~Hz}, 2 \mathrm{H}), 8.51(\mathrm{br}$ $\mathrm{dd}, J=8.1,3.2 \mathrm{~Hz}, 2 \mathrm{H}), 8.08$ (br s, 2H), 7.49 (br d, $J=7.6 \mathrm{~Hz}, 2 \mathrm{H}), 7.44$ (br dd, $J=$ 8.4, $4.4 \mathrm{~Hz}, 2 \mathrm{H}), 7.39(\mathrm{~d}, J=7.9 \mathrm{~Hz}, 2 \mathrm{H}), 7.33-7.28(\mathrm{~m}, 3 \mathrm{H}), 7.26-7.06(\mathrm{~m}, 16 \mathrm{H}), 4.92-4.83(\mathrm{~m}, 3 \mathrm{H}), 4.82-4.75(\mathrm{~m}, 2 \mathrm{H}), 4.7(\mathrm{q}, J$ $=7 \mathrm{~Hz}, 2 \mathrm{H}), 4.61(\mathrm{br} \mathrm{d}, J=4.6 \mathrm{~Hz}, 2 \mathrm{H}), 4.43(\mathrm{br} \mathrm{d}, J=7.3 \mathrm{~Hz}, 2 \mathrm{H}), 4.39-4.32(\mathrm{~m}, 2 \mathrm{H}), 4.16-4.1(\mathrm{~m}, 2 \mathrm{H}), 4.04(\mathrm{br} \mathrm{d}, J=8.2 \mathrm{~Hz}$, $4 \mathrm{H}), 3.88-3.81(\mathrm{~m}, 1 \mathrm{H}), 3.72-3.52(\mathrm{~m}, 3 \mathrm{H}), 3.51-3.37(\mathrm{~m}, 5 \mathrm{H}), 3.29-3.25(\mathrm{~m}, 1 \mathrm{H}), 3.2(\mathrm{~d}, J=2.1 \mathrm{~Hz}, 4 \mathrm{H}), 3.18-3(\mathrm{~m}, 8 \mathrm{H}), 2.97-$ $2.8(\mathrm{~m}, 10 \mathrm{H}), 2.80-2.72(\mathrm{~m}, 3 \mathrm{H}), 2.73-2.61(\mathrm{~m}, 2 \mathrm{H}), 2.49-2.35(\mathrm{~m}, 4 \mathrm{H}), 2.29-2.17(\mathrm{~m}, 18 \mathrm{H}), 2.15(\mathrm{br} \mathrm{s}, 1 \mathrm{H}), 2.1(\mathrm{br} \mathrm{s}, 1 \mathrm{H})$, 2.05-1.93 (m, 1H), $1.81(\mathrm{br} \mathrm{s}, 1 \mathrm{H}), 1.62(\mathrm{br} \mathrm{d}, J=10.7 \mathrm{~Hz}, 2 \mathrm{H}), 1.52(\mathrm{br} \mathrm{dd}, J=14.8,4.7 \mathrm{~Hz}, 2 \mathrm{H}), 1.4(\mathrm{br} \mathrm{d}, J=10.7 \mathrm{~Hz}, 2 \mathrm{H}), 1.19-$ 
$1.05(\mathrm{~m}, 27 \mathrm{H}), 1(\mathrm{br} \mathrm{dd}, J=11.7,6.9 \mathrm{~Hz}, 9 \mathrm{H}), 0.92(\mathrm{br} \mathrm{d}, J=6.4 \mathrm{~Hz}, 3 \mathrm{H}), 0.87(\mathrm{~d}, J=6.4 \mathrm{~Hz}, 4 \mathrm{H}), 0.8(\mathrm{br} \mathrm{d}, J=6.7 \mathrm{~Hz}, 3 \mathrm{H}), 0.71$ (br d, $J=6.7 \mathrm{~Hz}, 3 \mathrm{H}), 0.64($ br d, $J=7 \mathrm{~Hz}, 6 \mathrm{H})$.

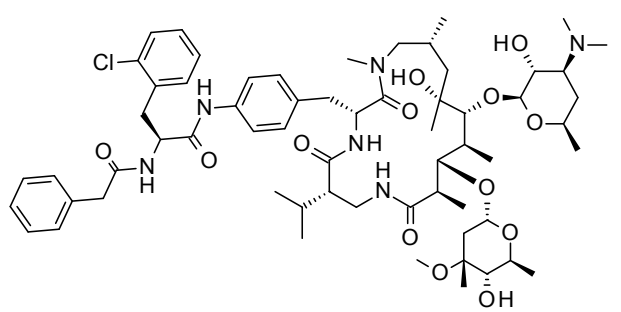

(2S)-3-(2-chlorophenyl)- $N$-[4-[[(3R,6S,10R,11S,12S,13R,14R,16R)-13-( $\beta$-Ddesosaminyl)oxy-14-hydroxy-11-( $\alpha$-L-cladinosyl)oxy-6-isopropyl1,10,12,14,16-pentamethyl-2,5,9-trioxo-1,4,8-triazacycloheptadec-3yl]methyl]phenyl]-2-[(2-phenylacetyl)amino]propanamide (20)

Following general procedure for Step 5: starting from $64(22 \mathrm{mg}, 0.07 \mathrm{mmol})$ and E-20 (60 mg, $0.07 \mathrm{mmol}$ ) title product ( $15 \mathrm{mg}$, yield $18 \%$, purity $98.15 \%$ ) was obtained by prep HPLC purification. $\mathrm{ES}^{+} \mathrm{m} / \mathrm{z} 1163.46[\mathrm{M}+\mathrm{H}]^{+} .{ }^{1} \mathrm{H}$ NMR (600 MHz, DMSO-d 6 ) $\delta / \mathrm{ppm} 10(\mathrm{~s}, 1 \mathrm{H}), 8.6-8.54(\mathrm{~m}, 1 \mathrm{H}), 7.74(\mathrm{br} \mathrm{d}, J=7.3 \mathrm{~Hz}$, $1 \mathrm{H}), 7.47(\mathrm{br} \mathrm{d}, J=8.4 \mathrm{~Hz}, 1 \mathrm{H}), 7.45-7.43(\mathrm{~m}, 1 \mathrm{H}), 7.39(\mathrm{~d}, J=7.7 \mathrm{~Hz}, 1 \mathrm{H}), 7.29$ (br d, $J=7.7 \mathrm{~Hz}, 1 \mathrm{H}$ ), 7.26-7.22 (m, 6H), 7.22-7.17 (m, 3H), 7.15 (br d, $J=7.2 \mathrm{~Hz}, 3 \mathrm{H}$ ), 5.19 (br d, $J=4.6 \mathrm{~Hz}, 1 \mathrm{H}$ ), 4.77 (br d, $J=$ $8.4 \mathrm{~Hz}, 1 \mathrm{H}), 4.72-4.68(\mathrm{~m}, 1 \mathrm{H}), 4.38-4.34(\mathrm{~m}, 1 \mathrm{H}), 4.22(\mathrm{br} \mathrm{d}, J=6.6 \mathrm{~Hz}, 1 \mathrm{H}), 4.09-4.01(\mathrm{~m}, 3 \mathrm{H}), 3.90-3.83(\mathrm{~m}, 1 \mathrm{H}), 3.76(\mathrm{br} \mathrm{d}$, $J=9.7 \mathrm{~Hz}, 1 \mathrm{H}), 3.60-3.54(\mathrm{~m}, 1 \mathrm{H}), 3.5-3.49(\mathrm{~m}, 1 \mathrm{H}), 3.48-3.42(\mathrm{~m}, 3 \mathrm{H}), 3.27-3.22(\mathrm{~m}, 2 \mathrm{H}), 3.22-3.13(\mathrm{~m}, 6 \mathrm{H}), 3.08-3.03(\mathrm{~m}$, $2 \mathrm{H}), 3.01(\mathrm{~d}, J=3.5 \mathrm{~Hz}, 3 \mathrm{H}), 2.91(\mathrm{br} \mathrm{d}, J=14.3 \mathrm{~Hz}, 2 \mathrm{H}), 2.87-2.8(\mathrm{~m}, 1 \mathrm{H}), 2.48-2.39(\mathrm{~m}, 2 \mathrm{H}), 2.3-2.26(\mathrm{~m}, 1 \mathrm{H}), 2.24-2.19(\mathrm{~m}$, $6 \mathrm{H}), 2.19-2.14(\mathrm{~m}, 2 \mathrm{H}), 1.92(\mathrm{td}, J=10.7,6 \mathrm{~Hz}, 1 \mathrm{H}), 1.77-1.7(\mathrm{~m}, 2 \mathrm{H}), 1.57(\mathrm{br} \mathrm{d}, J=14.9 \mathrm{~Hz}, 1 \mathrm{H}), 1.42-1.36(\mathrm{~m}, 1 \mathrm{H}), 1.36-1.3$ $(\mathrm{m}, 1 \mathrm{H}), 1.25-1.21(\mathrm{~m}, 1 \mathrm{H}), 1.2-1.14(\mathrm{~m}, 4 \mathrm{H}), 1.12(\mathrm{br} \mathrm{d}, J=6.1 \mathrm{~Hz}, 4 \mathrm{H}), 1.1(\mathrm{~s}, 4 \mathrm{H}), 1.08(\mathrm{br} \mathrm{d}, J=6.2 \mathrm{~Hz}, 4 \mathrm{H}), 1.06-1.03(\mathrm{~m}$, $3 \mathrm{H}), 1.02-0.95(\mathrm{~m}, 9 \mathrm{H}), 0.89-0.83(\mathrm{~m}, 3 \mathrm{H}), 0.58(\mathrm{br} \mathrm{d}, \mathrm{J}=5 \mathrm{~Hz}, 3 \mathrm{H})$.

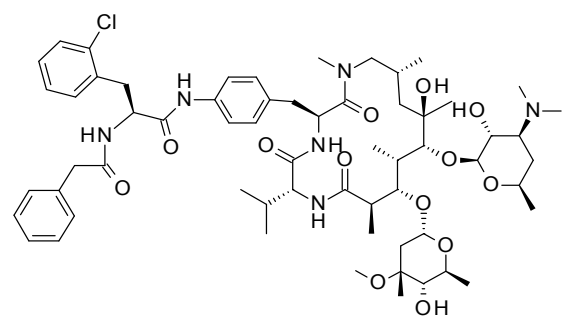

(2S)-3-(2-chlorophenyl)- $N$-[4-[[(3S,6R,9R,10S,11S,12R,13R,15R)-12-( $\beta$-Ddesosaminyl)oxy-13-hydroxy-10-( $\alpha$-L-cladinosyl)oxy-6-isopropyl-1,9,11,13,15pentamethyl-2,5,8-trioxo-1,4,7-triazacyclohexadec-3-yl]methyl] phenyl]-2-[(2phenylacetyl)amino]propanamide (21)

Following general procedure for Step 5: starting from 64 (172 mg, $0.49 \mathrm{mmol}, 1.1$ eq) and E-21 (382 $\mathrm{mg}, 0.45 \mathrm{mmol}$ ) title product ( $40 \mathrm{mg}$, yield $8 \%$, purity $98 \%$ ) was obtained by prep HPLC purification. ES+ m/z $1149.48[\mathrm{M}+\mathrm{H}]^{+} .{ }^{1} \mathrm{H}$ NMR (500 MHz, DMSO-d $\left.\mathrm{d}_{6}\right) \delta / \mathrm{ppm} 9.94(\mathrm{~s}, 1 \mathrm{H}), 8.66-8.56(\mathrm{~m}, 1 \mathrm{H}), 8.48(\mathrm{br} \mathrm{d}, J=8.2 \mathrm{~Hz}, 1 \mathrm{H})$, $8.08(\mathrm{br} \mathrm{t}, J=5.3 \mathrm{~Hz}, 1 \mathrm{H}), 7.43-7.35(\mathrm{~m}, 3 \mathrm{H}), 7.28(\mathrm{~d}, J=7.3 \mathrm{~Hz}, 1 \mathrm{H}), 7.25-7.12(\mathrm{~m}$, $8 \mathrm{H}), 7.09(\mathrm{br} \mathrm{d}, J=7.9 \mathrm{~Hz}, 2 \mathrm{H}), 4.91(\mathrm{br} \mathrm{d}, J=6.1 \mathrm{~Hz}, 1 \mathrm{H}), 4.80-4.73(\mathrm{~m}, 1 \mathrm{H}), 4.66(\mathrm{br} \mathrm{d}, J=4.3 \mathrm{~Hz}, 1 \mathrm{H}), 4.31-4.24(\mathrm{~m}, 2 \mathrm{H}), 4.17$ $(\mathrm{d}, J=2.4 \mathrm{~Hz}, 1 \mathrm{H}), 4.09-3.97(\mathrm{~m}, 2 \mathrm{H}), 3.83(\mathrm{br} \mathrm{s}, 1 \mathrm{H}), 3.74(\mathrm{br} \mathrm{t}, J=6.3 \mathrm{~Hz}, 1 \mathrm{H}), 3.55-3.48(\mathrm{~m}, 1 \mathrm{H}), 3.47-3.37(\mathrm{~m}, 4 \mathrm{H}), 3.2(\mathrm{~s}$, $3 \mathrm{H}), 3.16$ (br dd, $J=14.2,5.6 \mathrm{~Hz}, 1 \mathrm{H}), 3.08-2.98(\mathrm{~m}, 3 \mathrm{H}), 2.93-2.79(\mathrm{~m}, 3 \mathrm{H}), 2.71(\mathrm{~s}, 3 \mathrm{H}), 2.64-2.53(\mathrm{~m}, 1 \mathrm{H}), 2.48-2.42(\mathrm{~m}$, $1 \mathrm{H}), 2.25(\mathrm{br} \mathrm{d}, J=14.6 \mathrm{~Hz}, 1 \mathrm{H}), 2.22(\mathrm{~s}, 6 \mathrm{H}), 1.95(\mathrm{br} \mathrm{s}, 1 \mathrm{H}), 1.83-1.72(\mathrm{~m}, 2 \mathrm{H}), 1.59(\mathrm{br} \mathrm{d}, J=8.5 \mathrm{~Hz}, 1 \mathrm{H}), 1.46(\mathrm{br} \mathrm{dd}, J=14.8$, $4.4 \mathrm{~Hz}, 1 \mathrm{H}), 1.40-1.31(\mathrm{~m}, 1 \mathrm{H}), 1.30-1.21(\mathrm{~m}, 2 \mathrm{H}), 1.19-1.11(\mathrm{~m}, 9 \mathrm{H}), 1.09-1.03(\mathrm{~m}, 9 \mathrm{H}), 0.78(\mathrm{br} \mathrm{d}, J=6.4 \mathrm{~Hz}, 3 \mathrm{H}), 0.69-0.64$ $(\mathrm{m}, 5 \mathrm{H})$. 


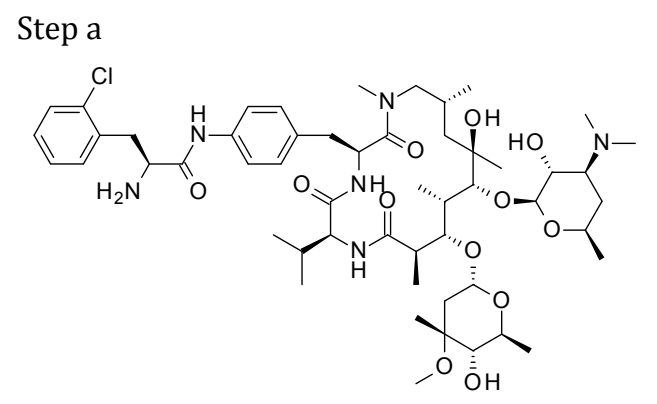

(2S)-2-amino-3-(2-chlorophenyl)- $N$-[4-[[(3S,6S,9R,10S,11S,12R,13R,15R)12-( $\beta$-D-desosaminyl)oxy-13-hydroxy-10-( $\alpha$-L-cladinosyl)oxy-6-isopropyl1,9,11,13,15-pentamethyl-2,5,8-trioxo-1,4,7-triazacyclohexadec-3yl]methyl]phenyl] propanamide (22a)

To a solution of (2S)-3-(2-chlorophenyl)-2-(9H-fluoren-9ylmethoxycarbonylamino)propanoic acid (86.6 mg, $0.2 \mathrm{mmol}$ ), amine E-22 (226 mg, $0.266 \mathrm{mmol})$ and DIPEA $(101.9 \mu \mathrm{L}, 0.585 \mathrm{mmol})$ in dry DMF (2.66 $\mathrm{mL}$ ) HATU (111.2 $\mathrm{mg}, 0.292 \mathrm{mmol}$ ) was added. The reaction mixture was left to stir at room temperature overnight. EtOAc $(30 \mathrm{~mL})$ was added and the organic layer was washed with sat. $\mathrm{NaHCO}_{3}(3 \times 15 \mathrm{~mL})$ and brine $(25 \mathrm{~mL})$. The organic layer was dried over $\mathrm{Na}_{2} \mathrm{SO}_{4}$. Solvent was removed under reduced pressure and the residue $\left(330.8 \mathrm{mg}\right.$; $\mathrm{ES}^{+} \mathrm{m} / \mathrm{z}$ $\left.1253.41[\mathrm{M}+\mathrm{H}]^{+}\right)$was dissolved in dry DCM $(4.33 \mathrm{~mL})$. Piperidine $(131.3 \mu \mathrm{L}, 1.329 \mathrm{mmol})$ was added and the resulting mixture was stirred at room temperature for $2 \mathrm{~h}$. The reaction mixture was concentrated under reduced pressure to afford the yellowish crude product which was purified by flash column chromatography $\left(\mathrm{SiO}_{2}, 12 \mathrm{~g}\right)$ with $\mathrm{DCM}: \mathrm{MeOH}: \mathrm{NH}_{4} \mathrm{OH}=90: 9: 1.5$ as an eluent to give the title product (162.5 mg, yield $59.2 \%$ ) as a white solid foam. ES ${ }^{+} \mathrm{m} / \mathrm{z} 1031.46[\mathrm{M}+\mathrm{H}]^{+}$.

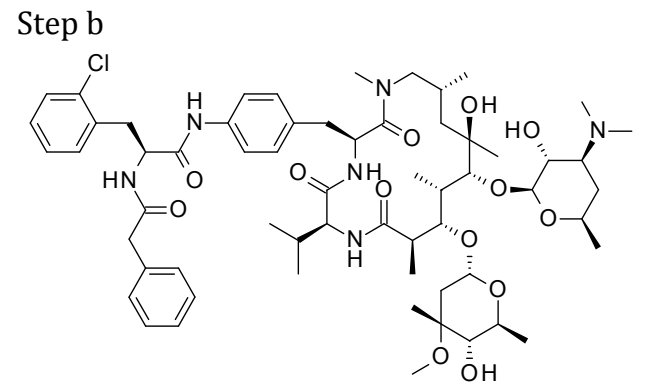

(2S)-3-(2-chlorophenyl)- $N$-[4-[[(3S,6S,9R,10S,11S,12R,13R,15R)-12-( $\beta$-Ddesosaminyl)oxy-13-hydroxy-10-( $\alpha$-L-cladinosyl)oxy-6-isopropyl1,9,11,13,15-pentamethyl-2,5,8-trioxo-1,4,7-triazacyclohexadec-3yl]methyl]phenyl]-2-[(2-phenylacetyl)amino]propanamide (22) PS-Carbodiimide resin ( $81 \mathrm{mg}, 0.089 \mathrm{mmol}$ ) was added to dry reaction vessel. 2-Phenylacetic acid (9.3 $\mathrm{mg}, 0.069 \mathrm{mmol})$ and HOBt $(7.4 \mathrm{mg}, 0.048 \mathrm{mmol})$, dissolved in a mixture of DCM $(1.25 \mathrm{~mL})$ and DMF $(75 \mu \mathrm{L})$, were added to the dry resin. The mixture was stirred at room temperature for $5 \mathrm{~min}$ upon which a solution of 22a (78.6 mg, $0.069 \mathrm{mmol})$ in a mixture of DCM $(1.25 \mathrm{~mL})$ and DMF $(75 \mu \mathrm{L})$ was added. The reaction mixture was left to stir at room temperature overnight. To the reaction a mixture of PS-carbodiimide resin (16.2 $\mathrm{mg}, 0.018 \mathrm{mmol}$ ), 2-phenylacetic acid (1.9 $\mathrm{mg}, 0.014 \mathrm{mmol})$ and HOBt $(1.5 \mathrm{mg}, 0.01 \mathrm{mmol})$ suspended in DCM $(0.5 \mathrm{~mL})$ and DMF (30 $\mu \mathrm{L})$ were added. Stirring at room temperature was continued overnight. The product was separated from the resin by filtration and the resin was washed with DCM $(3 \times 3 \mathrm{~mL}), \mathrm{MeOH}(3 \times 3 \mathrm{~mL})$ and DCM/MeOH 1:1 $(3 \times 3 \mathrm{~mL})$. The combined organic solvents were evaporated under reduced pressure to afford the raw product as a yellowish oil which was then suspended in EtOAc ( $30 \mathrm{~mL}$ ). The organic layer was washed with sat. $\mathrm{NaHCO}_{3}(3 \times 25 \mathrm{~mL})$, brine $(25 \mathrm{~mL})$, dried over anhydrous $\mathrm{Na}_{2} \mathrm{SO}_{4}$ and concentrated under reduced pressure yielding the crude product. The crude product was purified by flash column chromatography with DCM:MeOH: $\mathrm{NH}_{4} \mathrm{OH}=90: 9: 1.5$ as an eluent to give the title product (50 mg, yield 63\%, purity $93.9 \%$ ) as a white solid foam. $\mathrm{ES}^{+} \mathrm{m} / \mathrm{z} 1149.7[\mathrm{M}+\mathrm{H}]^{+}$. Two sets of signals in the NMR (most likely conformers). ${ }^{1} \mathrm{H}$ NMR $\left(500 \mathrm{MHz}, \mathrm{DMSO}-\mathrm{d}_{6}\right) \delta / \mathrm{ppm} 9.97$ $(\mathrm{s}, 1 \mathrm{H}), 9.95(\mathrm{~s}, 1 \mathrm{H}), 8.48(\mathrm{dd}, J=8.3,4.6 \mathrm{~Hz}, 2 \mathrm{H}), 8.45(\mathrm{~d}, J=6.8 \mathrm{~Hz}, 1 \mathrm{H}), 8.16(\mathrm{~d}, J=8.7 \mathrm{~Hz}, 1 \mathrm{H}), 7.82(\mathrm{~s}, 1 \mathrm{H}), 7.5(\mathrm{~s}, 1 \mathrm{H}), 7.43$ $(\mathrm{dd}, J=12.1,8.3 \mathrm{~Hz}, 4 \mathrm{H}), 7.40-7.35(\mathrm{~m}, 2 \mathrm{H}), 7.33-7.26(\mathrm{~m}, 2 \mathrm{H}), 7.26-7.09(\mathrm{~m}, 16 \mathrm{H}), 4.98-4.89(\mathrm{~m}, 1 \mathrm{H}), 4.89-4.81(\mathrm{~m}, 2 \mathrm{H})$, 4.81-4.73 (m, 2H), $4.5(\mathrm{~d}, J=7.2 \mathrm{~Hz}, 1 \mathrm{H}), 4.4(\mathrm{~d}, J=7.3 \mathrm{~Hz}, 2 \mathrm{H}), 4.33(\mathrm{~d}, J=7.8 \mathrm{~Hz}, 1 \mathrm{H}), 4.23(\mathrm{~d}, J=7.5 \mathrm{~Hz}, 1 \mathrm{H}), 4.12(\mathrm{~s}, 2 \mathrm{H})$, 4.10-3.96 (m, 2H), 3.96-3.83 (m, 2H), 3.80-3.56 (m, 4H), 3.54-3.4 (m, 4H), 3.28-3.07 (m, 2H), 3.21 (d, J = 6.7 Hz, 6H), 3.07$2.96(\mathrm{~m}, 4 \mathrm{H}), 2.96-2.85(\mathrm{~m}, 4 \mathrm{H}), 2.81-2.63(\mathrm{~m}, 4 \mathrm{H}), 2.63-2.52(\mathrm{~m}, 1 \mathrm{H}), 2.48-2.35(\mathrm{~m}, 1 \mathrm{H}), 2.34-2.09(\mathrm{~m}, 4 \mathrm{H}), 2.22(\mathrm{~d}, J=9.2$ $\mathrm{Hz}, 12 \mathrm{H}), 2.04-1.91(\mathrm{~m}, 2 \mathrm{H}), 1.85(\mathrm{t}, J=7.4 \mathrm{~Hz}, 2 \mathrm{H}), 1.65-1.45(\mathrm{~m}, 4 \mathrm{H}), 1.38-1.01(\mathrm{~m}, 34 \mathrm{H}), 0.96(\mathrm{dd}, J=10.2,7.3 \mathrm{~Hz}, 6 \mathrm{H}), 0.87$ $(\mathrm{d}, J=6.6 \mathrm{~Hz}, 2 \mathrm{H}), 0.85-0.78(\mathrm{~m}, 6 \mathrm{H}), 0.72(\mathrm{dd}, J=11.0,6.6 \mathrm{~Hz}, 6 \mathrm{H})$.

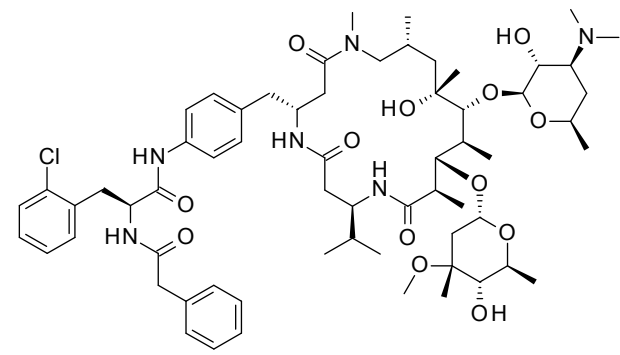

(2R)-3-(2-chlorophenyl)- $N$-[4-[[(4R,8R,11R,12S,13S,14R,15R,17R)-14-( $\beta$-Ddesosaminyl)oxy-15-hydroxy-12-( $\alpha$-L-cladinosyl)oxy-8-isopropyl1,11,13,15,17-pentamethyl-2,6,10-trioxo-1,5,9-triazacycloctadec-4yl]methyl]phenyl]-2-[(2-phenylacetyl)amino]propanamide (23)

Following general procedure for Step 5: starting from 64 (46 mg, $0.13 \mathrm{mmol}$ ) and E-23 (110 mg, $0.13 \mathrm{mmol}$ ) title product (33 mg, yield $21 \%$, purity 85.4 $\%$ ) was obtained by prep HPLC purification. $\mathrm{ES}^{+} \mathrm{m} / \mathrm{z} 1177.83[\mathrm{M}+\mathrm{H}]^{+} .{ }^{1} \mathrm{H}$ NMR (DMSO-d, $500 \mathrm{MHz}) \delta /$ ppm $10(\mathrm{~s}, 1 \mathrm{H}), 9.98(\mathrm{~s}, 1 \mathrm{H}), 8.53-8.48(\mathrm{~m}, 2 \mathrm{H}), 7.83$ (br d, J = 8.9 Hz, 1H), 7.52-7.46 (m, 4H), $7.44(\mathrm{br} \mathrm{d}, \mathrm{J}=7.6 \mathrm{~Hz}, 2 \mathrm{H}), 7.4(\mathrm{br} \mathrm{d}, \mathrm{J}$ $=7.9 \mathrm{~Hz}, 2 \mathrm{H}), 7.33-7.29(\mathrm{~m}, 2 \mathrm{H}), 7.26-7.13(\mathrm{~m}, 20 \mathrm{H}), 7.06(\mathrm{br} \mathrm{d}, \mathrm{J}=8.2 \mathrm{~Hz}$, 2H), 4.82-4.74 (m, 2H), 4.71 (br d, J = 4.6 Hz, 1H), 4.47 (br d, J = 3.4 Hz, 1H), 4.41 (br d, J = 7.3 Hz, 1H), 4.34 (br d, J = 7.3 Hz, $1 \mathrm{H}), 4.25-4.15(\mathrm{~m}, 4 \mathrm{H}), 4.14-3.92(\mathrm{~m}, 8 \mathrm{H}), 3.88(\mathrm{br} \mathrm{d}, \mathrm{J}=7.9 \mathrm{~Hz}, 1 \mathrm{H}), 3.70-3.63(\mathrm{~m}, 3 \mathrm{H}), 3.50-3.41(\mathrm{~m}, 7 \mathrm{H}), 3.30-3.13(\mathrm{~m}$, $13 \mathrm{H}), 3.09-3(\mathrm{~m}, 4 \mathrm{H}), 2.90-2.85(\mathrm{~m}, 6 \mathrm{H}), 2.82-2.78(\mathrm{~m}, 5 \mathrm{H}), 2.76-2.68(\mathrm{~m}, 2 \mathrm{H}), 2.55(\mathrm{br} \mathrm{d}, \mathrm{J}=5.8 \mathrm{~Hz}, 2 \mathrm{H}), 2.48-2.36(\mathrm{~m}, 6 \mathrm{H})$, 2.23 (br d, J = 8.9 Hz, 14H), 2.11-2.01 (m, 4H), 1.65-1.59 (m, 3H), 1.44 (br d, J = 10.4 Hz, 3H), 1.29-1.25 (m, 1H), 1.16-1.11 
(m, 13H), 1.10-1.06 (m, 16H), 0.99-0.94 (m,13H), $0.89(\mathrm{br} \mathrm{d}, \mathrm{J}=6.7 \mathrm{~Hz}, 4 \mathrm{H}), 0.86(\mathrm{br} \mathrm{d}, \mathrm{J}=6.4 \mathrm{~Hz}, 3 \mathrm{H}), 0.8(\mathrm{br} \mathrm{t}, \mathrm{J}=6.6 \mathrm{~Hz}$, $7 \mathrm{H})$.

\section{Preparation of Compound 24}

Step a

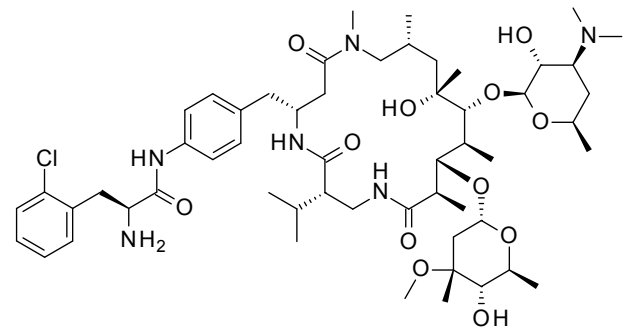

(2S)-2-amino-3-(2-chlorophenyl)- $N$-[4-[[(4R,7S,11R,12S,13S,14R,15R,17R)14-( $\beta$-D-desosaminyl)oxy-15-hydroxy-12-( $\alpha$-L-cladinosyl)oxy-7-isopropyl1,11,13,15,17-pentamethyl-2,6,10-trioxo-1,5,9-triazacyclooctadec-4yl]methyl]phenyl]propanamide (24a)

To a solution of (2S)-3-(2-chlorophenyl)-2-(9H-fluoren-9ylmethoxycarbonylamino) propanoic acid ( $86.6 \mathrm{mg}, 0.2 \mathrm{mmol}), \mathbf{E}-24$ (166.5 $\mathrm{mg}, 0.19 \mathrm{mmol})$ and DIPEA $(72.7 \mu \mathrm{L}, 0.417 \mathrm{mmol})$ in dry DMF $(1.9 \mathrm{~mL}) \mathrm{HATU}$ $(79.3 \mathrm{mg}, 0.209 \mathrm{mmol})$ was added. The reaction mixture was left to stir at room temperature overnight. EtOAc $(30 \mathrm{~mL})$ was added, and the organic layer was washed with sat. $\mathrm{NaHCO}_{3}(3 \times 15 \mathrm{~mL})$ and brine $(25 \mathrm{~mL})$. The organic layer was dried over $\mathrm{Na}_{2} \mathrm{SO}_{4}$. Solvent was removed under reduced pressure and the residue [241.6 mg), ES , $\mathrm{m} / \mathrm{z}$ $\left.1281.49[\mathrm{M}+\mathrm{H}]^{+}\right]$was dissolved in dry DCM $(3.09 \mathrm{~mL})$. Piperidine $(93.6 \mu \mathrm{L}, 0.948 \mathrm{mmol})$ was added and the resulting mixture was stirred at room temperature for $2 \mathrm{~h}$. The reaction mixture was concentrated under reduced pressure to afford the yellowish crude product which was purified by flash column chromatography with DCM:MeOH: $\mathrm{NH}_{4} \mathrm{OH}=90: 9: 1.5$ as an eluent to give the title product (137 mg, yield $68 \%$ ) as a white solid foam. $\mathrm{ES}^{+} \mathrm{m} / \mathrm{z} 1059.46[\mathrm{M}+\mathrm{H}]^{+}$.

Step b

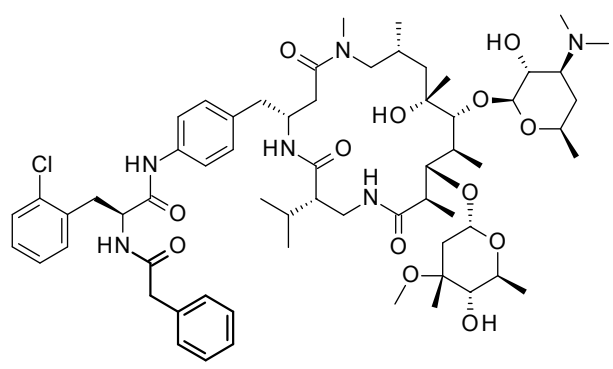

(2S)-3-(2-chlorophenyl)- $N$-[4-[[(4R,7S,11R,12S,13S,14R,15R,17R)-14-( $\beta$-Ddesosaminyl)oxy-15-hydroxy-12-( $\alpha$-L-cladinosyl)oxy-7-isopropyl-

1,11,13,15,17-pentamethyl-2,6,10-trioxo-1,5,9-triazacyclooctadec-4yl]methyl]phenyl]-2-[(2-phenylacetyl)amino]propanamide (24)

PS-Carbodiimide resin $(76.2 \mathrm{mg}, 0.084 \mathrm{mmol})$ was added to a dry reaction vessel. 2-Phenylacetic acid ( $8.8 \mathrm{mg}, 0.064 \mathrm{mmol})$ and HOBt $(6.9 \mathrm{mg}, 0.045$ $\mathrm{mmol})$, dissolved in a mixture of DCM $(1.15 \mathrm{~mL})$ and DMF ( $70 \mu \mathrm{L})$, were added to the dry resin. The mixture was stirred at room temperature for 5 min upon which a solution of $24 a(68.3 \mathrm{mg}, 0.064 \mathrm{mmol})$ in a mixture of DCM $(1.15 \mathrm{~mL})$ and DMF $(70 \mu \mathrm{L})$ was added. The reaction mixture was left to stir at room temperature overnight. The product was separated from the resin by filtration and the resin was washed with DCM $(3 \times 2 \mathrm{~mL}), \mathrm{MeOH}(3 \times 2 \mathrm{~mL})$ and DCM/MeOH 1:1 $(3 \times 2 \mathrm{~mL})$. The combined organic solvents were evaporated under reduced pressure to afford the raw product as a yellowish oil which was then suspended in EtOAc $(25 \mathrm{~mL})$. The organic layer was dried over $\mathrm{Na}_{2} \mathrm{SO}_{4}$ and concentrated under reduced pressure yielding the crude product. The crude product was purified by flash column chromatography with DCM:MeOH: $\mathrm{NH}_{4} \mathrm{OH}=90: 9: 1.5$ as an eluent to give the title product ( $60.2 \mathrm{mg}$, yield $82.4 \%$, purity $95.7 \%$ ) as a white solid foam. ES+ $\mathrm{m} / \mathrm{z} 1177.53$ [M+H] $]^{+}$. Two sets of signals in the NMR (most likely conformers). ${ }^{1} \mathrm{H}$ NMR $\left(500 \mathrm{MHz}\right.$, DMSO-d $\left.\mathrm{d}_{6}\right) \delta / \mathrm{ppm} 10.02(\mathrm{~s}, 1 \mathrm{H}), 9.96(\mathrm{~s}, 1 \mathrm{H}), 8.55-8.47(\mathrm{~m}$, $3 \mathrm{H}), 7.71(\mathrm{br} \mathrm{s}, 1 \mathrm{H}), 7.61-7.53(\mathrm{~m}, 2 \mathrm{H}), 7.5(\mathrm{~d}, J=8.2 \mathrm{~Hz}, 2 \mathrm{H}), 7.48-7.42(\mathrm{~m}, 2 \mathrm{H}), 7.39(\mathrm{~d}, J=7 \mathrm{~Hz}, 2 \mathrm{H}), 7.3(\mathrm{dd}, J=7.6,1.5 \mathrm{~Hz}$, $2 \mathrm{H}), 7.26-7.14(\mathrm{~m}, 13 \mathrm{H}), 7.13-7.08(\mathrm{~m}, 3 \mathrm{H}), 4.93(\mathrm{br} \mathrm{d}, J=4.6 \mathrm{~Hz}, 1 \mathrm{H}), 4.81-4.74(\mathrm{~m}, 2 \mathrm{H}), 4.62(\mathrm{br} \mathrm{d}, J=4.6 \mathrm{~Hz}, 2 \mathrm{H}), 4.42(\mathrm{br}$ d, $J=7.3 \mathrm{~Hz}, 2 \mathrm{H}$ ), 4.37 (br d, $J=7 \mathrm{~Hz}, 2 \mathrm{H}), 4.23-4.17(\mathrm{~m}, 2 \mathrm{H}), 4.15-4.07(\mathrm{~m}, 4 \mathrm{H}), 4.07-3.9(\mathrm{~m}, 4 \mathrm{H}), 3.66$ (br s, 2H), 3.55-3.37 (m, 8H), 3.24-3.15 (m, 8H), 3.14-2.99 (m, 8H), 2.97-2.8 (m, 8H), $2.78(\mathrm{~s}, 2 \mathrm{H}), 2.65$ (br dd, $J=13.6,8.1 \mathrm{~Hz}, 2 \mathrm{H}), 2.60-2.56(\mathrm{~m}$, $1 \mathrm{H}), 2.49-2.42(\mathrm{~m}, 4 \mathrm{H}), 2.38-2.3(\mathrm{~m}, 1 \mathrm{H}), 2.26-2.21(\mathrm{~m}, 14 \mathrm{H}), 2.14-2.02(\mathrm{~m}, 2 \mathrm{H}), 1.97-1.83(\mathrm{~m}, 4 \mathrm{H}), 1.81-1.73(\mathrm{~m}, 1 \mathrm{H}), 1.72-$ $1.54(\mathrm{~m}, 3 \mathrm{H}), 1.48-1.39(\mathrm{~m}, 3 \mathrm{H}), 1.27-1.2(\mathrm{~m}, 3 \mathrm{H}), 1.17-1.07(\mathrm{~m}, 26 \mathrm{H}), 1.05$ (br d, J = 7 Hz, 4H), 1.02-0.94 (m, 13H), 0.9 (br d, $J=6.7 \mathrm{~Hz}, 2 \mathrm{H}), 0.87(\mathrm{~d}, J=6.7 \mathrm{~Hz}, 3 \mathrm{H}), 0.78(\mathrm{br} \mathrm{d}, J=6.4 \mathrm{~Hz}, 3 \mathrm{H}), 0.69(\mathrm{br} \mathrm{d}, J=6.4 \mathrm{~Hz}, 3 \mathrm{H}), 0.64(\mathrm{~d}, J=6.4 \mathrm{~Hz}, 3 \mathrm{H})$.

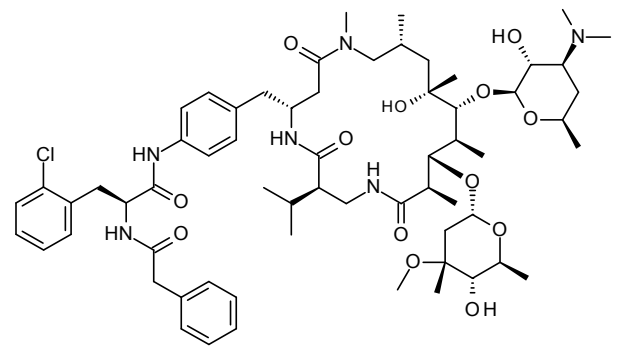

(2S)-3-(2-chlorophenyl)- $N$-[4-[[(4R,7R,11R,12S,13S,14R, 15R,17R)-14-( $\beta$-Ddesosaminyl)oxy-15-hydroxy-12-( $\alpha$-L-cladinosyl)oxy-7-isopropyl1,11,13,15,17-pentamethyl-2,6,10-trioxo-1,5,9-triazacyclooctadec-4yl]methyl]phenyl]-2-[(2-phenylacetyl)amino]propanamide (25) Following general procedure for Step 5: starting from 64 (39.8 mg, 0.125 $\mathrm{mmol}$ ) and E-25 (100 mg, $0.114 \mathrm{mmol}$ ) title product was obtained as a white solid foam (93.7 mg, yield $69.8 \%$, purity $93.1 \%$ ). Purification was performed by flash column chromatography with DCM:MeOH: $\mathrm{NH}_{4} \mathrm{OH}=90: 9: 1.5$ as an eluent. ES ${ }^{+} \mathrm{m} / \mathrm{z} 1177.82[\mathrm{M}+\mathrm{H}]^{+}$. Two sets of signals in the NMR (most likely conformers). ${ }^{1} \mathrm{H}$ NMR (500 MHz, DMSO-d 6 ) $\delta / \mathrm{ppm} 9.96(\mathrm{~s}, 1 \mathrm{H}), 9.95(\mathrm{~s}, 1 \mathrm{H})$,

8.49 (br d, $J=7.3 \mathrm{~Hz}, 2 \mathrm{H}$ ), 7.88 (br d, $J=8.9 \mathrm{~Hz}, 1 \mathrm{H}), 7.82-7.76(\mathrm{~m}, 1 \mathrm{H}), 7.72$ (br d, $J=9.5 \mathrm{~Hz}, 1 \mathrm{H}$ ), 7.48-7.38 (m, 7H), 7.30$7.14(\mathrm{~m}, 20 \mathrm{H}), 7.1(\mathrm{~d}, J=8.5 \mathrm{~Hz}, 2 \mathrm{H}), 4.89-4.85(\mathrm{~m}, 1 \mathrm{H}), 4.80-4.75(\mathrm{~m}, 2 \mathrm{H}), 4.70-4.68(\mathrm{~m}, 2 \mathrm{H}), 4.42-4.36(\mathrm{~m}, 3 \mathrm{H}), 4.35-4.23$ $(\mathrm{m}, 4 \mathrm{H}), 4.12(\mathrm{~d}, J=7.9 \mathrm{~Hz}, 1 \mathrm{H}), 4.07-3.95(\mathrm{~m}, 6 \mathrm{H}), 3.83-3.77(\mathrm{~m}, 1 \mathrm{H}), 3.58(\mathrm{br} \mathrm{d}, J=13.1 \mathrm{~Hz}, 3 \mathrm{H}), 3.50-3.41(\mathrm{~m}, 6 \mathrm{H}), 3.26-$ $3.14(\mathrm{~m}, 10 \mathrm{H}), 3.10-3.01(\mathrm{~m}, 6 \mathrm{H}), 3(\mathrm{~s}, 3 \mathrm{H}), 2.94-2.84(\mathrm{~m}, 3 \mathrm{H}), 2.79(\mathrm{br} \mathrm{d}, J=4 \mathrm{~Hz}, 1 \mathrm{H}), 2.76(\mathrm{~s}, 4 \mathrm{H}), 2.69-2.63(\mathrm{~m}, 2 \mathrm{H}), 2.61-$ 
2.53 (m, 3H), 2.50-2.46 (m, 1H), 2.28 (br s, 1H), 2.23 (br d, J = 2.7 Hz, 12H), 2.13-2.05 (m, 3H), 1.90-1.84 (m, $1 \mathrm{H}), 1.81$ (br s, $1 \mathrm{H}), 1.69-1.58(\mathrm{~m}, 4 \mathrm{H}), 1.56-1.51(\mathrm{~m}, 1 \mathrm{H}), 1.42(\mathrm{td}, J=15.0,4.4 \mathrm{~Hz}, 2 \mathrm{H}), 1.32(\mathrm{br} \mathrm{d}, J=14 \mathrm{~Hz}, 2 \mathrm{H}), 1.26-1.19(\mathrm{~m}, 2 \mathrm{H}), 1.17-$ $1.09(\mathrm{~m}, 25 \mathrm{H}), 1.08-1.02(\mathrm{~m}, 11 \mathrm{H}), 1(\mathrm{br} \mathrm{d}, J=6.7 \mathrm{~Hz}, 3 \mathrm{H}), 0.97-0.92(\mathrm{~m}, 9 \mathrm{H}), 0.81(\mathrm{br} \mathrm{d}, J=6.1 \mathrm{~Hz}, 3 \mathrm{H}), 0.69(\mathrm{br} \mathrm{d}, J=6.7 \mathrm{~Hz}$, $3 \mathrm{H}), 0.57$ (br d, $J=6.4 \mathrm{~Hz}, 3 \mathrm{H}), 0.51(\mathrm{br} \mathrm{d}, J=5.8 \mathrm{~Hz}, 2 \mathrm{H})$.

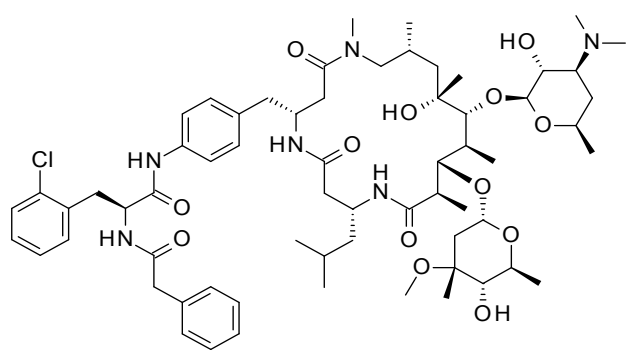

(2S)-3-(2-chlorophenyl)- $N$-[4-[[(4R,8R,11R,12S,13S,14R,15R,17R)-14-( $\beta$-Ddesosaminyl)oxy-15-hydroxy-12-( $\alpha$-L-cladinosyl)oxy-8-isobutyl1,11,13,15,17-pentamethyl-2,6,10-trioxo-1,5,9-triazacyclooctadec-4yl]methyl]phenyl]-2-[(2-phenylacetyl)amino]propanamide (26) Following general procedure for Step 5: starting from $64(25 \mathrm{mg}, 0.08 \mathrm{mmol})$ and E-26 (70 mg, $0.08 \mathrm{mmol})$ title product ( $10 \mathrm{mg}$, yield $11 \%$, purity 95.86 \%) was obtained by prep HPLC purification. $\mathrm{ES}^{+} \mathrm{m} / \mathrm{z} 1191.83[\mathrm{M}+\mathrm{H}]^{+} .{ }^{1} \mathrm{H}$ NMR (600 MHz, DMSO-d 6 ) $\delta / \mathrm{ppm} 10.03$ (s, 1H), $8.51(\mathrm{~d}, J=8.6 \mathrm{~Hz}, 1 \mathrm{H}), 8.14(\mathrm{br} \mathrm{d}$, $J=8.3 \mathrm{~Hz}, 1 \mathrm{H}), 8.01-7.97(\mathrm{~m}, 1 \mathrm{H}), 7.53-7.46(\mathrm{~m}, 2 \mathrm{H}), 7.4(\mathrm{dd}, J=8.0,0.8 \mathrm{~Hz}$, $1 \mathrm{H}), 7.32(\mathrm{br} \mathrm{d}, J=7.5 \mathrm{~Hz}, 1 \mathrm{H}), 7.26-7.22(\mathrm{~m}, 3 \mathrm{H}), 7.22-7.17(\mathrm{~m}, 2 \mathrm{H}), 7.14(\mathrm{br}$ $\mathrm{d}, J=7.2 \mathrm{~Hz}, 2 \mathrm{H}), 7.06(\mathrm{br} \mathrm{d}, J=8.3 \mathrm{~Hz}, 2 \mathrm{H}), 4.85-4.78(\mathrm{~m}, 2 \mathrm{H}), 4.4(\mathrm{br} \mathrm{d}, J=7 \mathrm{~Hz}, 1 \mathrm{H}), 4.28(\mathrm{br} \mathrm{d}, J=8.3 \mathrm{~Hz}, 1 \mathrm{H}), 4.21-4.15(\mathrm{~m}$, $1 \mathrm{H}), 4.11-4.01(\mathrm{~m}, 1 \mathrm{H}), 3.98-3.93(\mathrm{~m}, 1 \mathrm{H}), 3.91-3.86(\mathrm{~m}, 1 \mathrm{H}), 3.82(\mathrm{~s}, 1 \mathrm{H}), 3.64-3.57(\mathrm{~m}, 1 \mathrm{H}), 3.48(\mathrm{br} \mathrm{s}, 2 \mathrm{H}), 3.44-3.41(\mathrm{~m}$, $1 \mathrm{H}), 3.29-3.25(\mathrm{~m}, 1 \mathrm{H}), 3.22(\mathrm{~s}, 3 \mathrm{H}), 3.21-3.19(\mathrm{~m}, 1 \mathrm{H}), 3.18-3.12(\mathrm{~m}, 3 \mathrm{H}), 3.09-3.01(\mathrm{~m}, 2 \mathrm{H}), 2.91-2.87(\mathrm{~m}, 1 \mathrm{H}), 2.85-2.8(\mathrm{~m}$, $1 \mathrm{H}), 2.73(\mathrm{~s}, 3 \mathrm{H}), 2.25-2.22(\mathrm{~m}, 7 \mathrm{H}), 2.06-2.01(\mathrm{~m}, 1 \mathrm{H}), 2-1.95(\mathrm{~m}, 1 \mathrm{H}), 1.85-1.8(\mathrm{~m}, 1 \mathrm{H}), 1.64-1.59(\mathrm{~m}, 1 \mathrm{H}), 1.50-1.44(\mathrm{~m}$, $1 \mathrm{H}), 1.32-1.24$ (m, 3H), 1.19-1.05 (m, 19H), 1.01 (br d, $J=6.8 \mathrm{~Hz}, 5 \mathrm{H}), 0.94-0.87$ (m, 1H), 0.83-0.79 (m, 4H), 0.71 (ddd, $J=$ $12.7,6.6,2.9 \mathrm{~Hz}, 6 \mathrm{H})$.

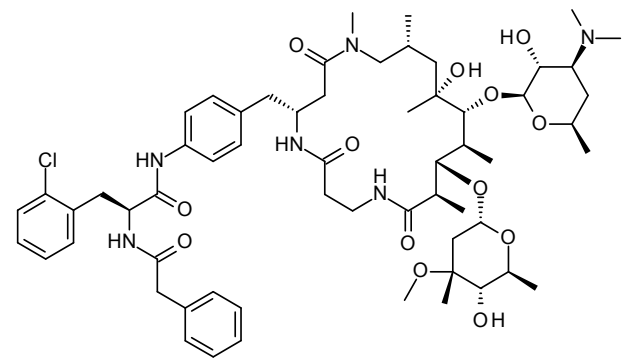

(2S)-3-(2-chlorophenyl)- $N$-[4-[[(4R,11R,12S,13S,14R,15R,17R)-14-( $\beta$-Ddesosaminyl)oxy-15-hydroxy-12-( $\alpha$-L-cladinosyl)oxy-1,11,13,15,17pentamethyl-2,6,10-trioxo-1,5,9-triazacyclooctadec-4-yl]methyl]phenyl]-2[(2-phenylacetyl)amino]propanamide (27)

Following general procedure for Step 5: starting from $64(71 \mathrm{mg}, 0.222 \mathrm{mmol})$ and E-27 (186 mg, $0.222 \mathrm{mmol}$ ) title product ( $55 \mathrm{mg}$, yield $20 \%$, purity 92.3 \%) was obtained by prep HPLC purification. $\mathrm{ES}^{+}, \mathrm{m} / \mathrm{z} 1135.9[\mathrm{M}+\mathrm{H}]^{+} .{ }^{1} \mathrm{H}$ NMR (500 MHz, DMSO-d 6 ) $\delta /$ ppm 10 (br s, $1 \mathrm{H}), 8.51(\mathrm{br} \mathrm{d}, J=8.2 \mathrm{~Hz}, 1 \mathrm{H}), 7.81(\mathrm{br}$ $\mathrm{d}, J=8.9 \mathrm{~Hz}, 1 \mathrm{H}), 7.50-7.45(\mathrm{~m}, 3 \mathrm{H}), 7.4(\mathrm{br} \mathrm{d}, J=7.6 \mathrm{~Hz}, 1 \mathrm{H}), 7.32(\mathrm{br} \mathrm{d}, J=$ $6.4 \mathrm{~Hz}, 1 \mathrm{H}), 7.24(\mathrm{br} \mathrm{d}, J=7.3 \mathrm{~Hz}, 3 \mathrm{H}), 7.21(\mathrm{br} \mathrm{s}, 2 \mathrm{H}), 7.15(\mathrm{br} \mathrm{d}, J=7 \mathrm{~Hz}, 3 \mathrm{H})$ $7.1(\mathrm{br} \mathrm{d}, J=8.2 \mathrm{~Hz}, 2 \mathrm{H}), 4.79(\mathrm{br} \mathrm{d}, J=5.2 \mathrm{~Hz}, 1 \mathrm{H}), 4.71-4.68(\mathrm{~m}, 1 \mathrm{H}), 4.37$ (br d, $J=7 \mathrm{~Hz}, 1 \mathrm{H}), 4.28-4.25(\mathrm{~m}, 2 \mathrm{H}), 4.13(\mathrm{br} \mathrm{d}$, $J=7.9 \mathrm{~Hz}, 1 \mathrm{H}), 4.08-4.02(\mathrm{~m}, 3 \mathrm{H}), 3.53-3.49(\mathrm{~m}, 2 \mathrm{H}), 3.46$ (br d, $J=8.5 \mathrm{~Hz}, 2 \mathrm{H}), 3.40-3.37(\mathrm{~m}, 1 \mathrm{H}), 3.23-3.19(\mathrm{~m}, 4 \mathrm{H}), 3.05$ (br dd, $J=13.3,9 \mathrm{~Hz}, 3 \mathrm{H}), 2.91-2.88(\mathrm{~m}, 2 \mathrm{H}), 2.73(\mathrm{~s}, 4 \mathrm{H}), 2.66(\mathrm{br} \mathrm{d}, J=8.2 \mathrm{~Hz}, 1 \mathrm{H}), 2.30-2.26(\mathrm{~m}, 2 \mathrm{H}), 2.23(\mathrm{br} \mathrm{s}, 8 \mathrm{H}), 2.18$ (br d, $J=11 \mathrm{~Hz}, 1 \mathrm{H}), 2.09-2(\mathrm{~m}, 3 \mathrm{H}), 1.66-1.58(\mathrm{~m}, 1 \mathrm{H}), 1.50-1.43(\mathrm{~m}, 1 \mathrm{H}), 1.29(\mathrm{br} \mathrm{s}, 2 \mathrm{H}), 1.18(\mathrm{~s}, 3 \mathrm{H}), 1.16-1.1(\mathrm{~m}, 10 \mathrm{H})$, $1.07-1.03(\mathrm{~m}, 6 \mathrm{H}), 0.96(\mathrm{br} \mathrm{dd}, J=16.8,6.7 \mathrm{~Hz}, 2 \mathrm{H}), 0.88(\mathrm{br} \mathrm{d}, J=6.7 \mathrm{~Hz}, 2 \mathrm{H})$.

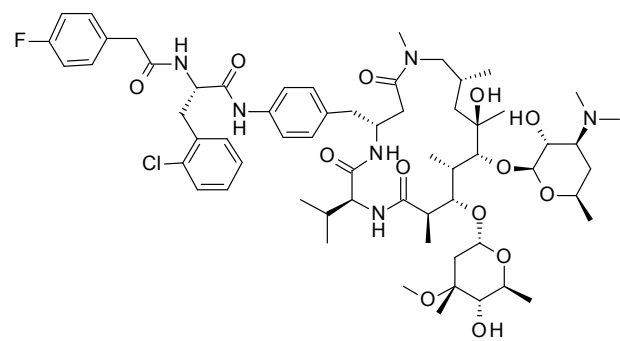

(2S)-3-(2-chlorophenyl)- $N$-[4-[[(2S,5R,10R,12R,13R,14S,15S,16R)-13-( $\beta$-Ddesosaminyl)oxy-12-hydroxy-15-( $\alpha$-L-cladinosyl)oxy-2-isopropyl8,10,12,14,16-pentamethyl-3,7,17-trioxo-1,4,8-triazacycloheptadec-5yl]methyl]phenyl]-2-[[2-(4-fluorophenyl)acetyl]amino]propenamide (34) Starting from 66 (40 mg, $0.12 \mathrm{mmol})$ and E1a $(100 \mathrm{mg}, 0.12 \mathrm{mmol})$ title product (40 mg, yield $28 \%$, purity $89.61 \%$ ) was obtained by prep HPLC purification. $\mathrm{ES}^{+} \mathrm{m} / \mathrm{z}=1181.71[\mathrm{M}+\mathrm{H}]^{+}$. Two sets of signals in the NMR (most likely conformers). ${ }^{1} \mathrm{H}$ NMR (600 MHz, DMSO-d 6 ) $\delta / \mathrm{ppm} 9.99(\mathrm{~s}, 1 \mathrm{H}), 9.95(\mathrm{~s}$, $1 \mathrm{H}), 8.53-8.47(\mathrm{~m}, 3 \mathrm{H}), 8.11(\mathrm{br} \mathrm{s}, 2 \mathrm{H}), 7.45(\mathrm{~d}, J=8.4 \mathrm{~Hz}, 2 \mathrm{H}), 7.42(\mathrm{~d}, J=7.9$ $\mathrm{Hz}, 2 \mathrm{H}), 7.38$ (br d, $J=7.9 \mathrm{~Hz}, 2 \mathrm{H}), 7.27(\mathrm{br} \mathrm{d}, J=7.7 \mathrm{~Hz}, 2 \mathrm{H}), 7.24-7.21(\mathrm{~m}$, 3H), 7.19-7.16 (m, 6H), 7.13-7.1 (m, 6H), $7.06(\mathrm{t}, J=8.6 \mathrm{~Hz}, 4 \mathrm{H}), 4.79-4.76(\mathrm{~m}, 2 \mathrm{H}), 4.65-4.61(\mathrm{~m}, 2 \mathrm{H}), 4.45(\mathrm{~d}, J=7.2 \mathrm{~Hz}, 2 \mathrm{H})$, $4.40-4.35(\mathrm{~m}, 2 \mathrm{H}), 4.29(\mathrm{~d}, J=7.7 \mathrm{~Hz}, 2 \mathrm{H}), 4.23(\mathrm{~d}, J=8.3 \mathrm{~Hz}, 2 \mathrm{H}), 4.17-4.11(\mathrm{~m}, 2 \mathrm{H}), 4.06-4.01(\mathrm{~m}, 4 \mathrm{H}), 3.99-3.94(\mathrm{~m}, 1 \mathrm{H})$, 3.91-3.87 (m, 1H), $3.86(\mathrm{~s}, 2 \mathrm{H}), 3.71(\mathrm{~s}, 1 \mathrm{H}), 3.68-3.64(\mathrm{~m}, 2 \mathrm{H}), 3.51(\mathrm{br} \mathrm{d}, J=7 \mathrm{~Hz}, 2 \mathrm{H}), 3.48(\mathrm{~s}, 1 \mathrm{H}), 3.44(\mathrm{~d}, J=10.1 \mathrm{~Hz}, 5 \mathrm{H})$, 3.22-3.14 (m, 9H), 3.09-3.01 (m, 6H), 3-2.94 (m, 1H), 2.91-2.87 (m, 2H), $2.79(\mathrm{~s}, 3 \mathrm{H}), 2.72-2.67(\mathrm{~m}, 2 \mathrm{H}), 2.62-2.56(\mathrm{~m}, 5 \mathrm{H})$, 2.47 (br s, 3H), 2.40-2.36 (m, 2H), $2.26(\mathrm{br} \mathrm{d}, J=15.2 \mathrm{~Hz}, 2 \mathrm{H}), 2.23(\mathrm{~s}, 13 \mathrm{H}), 2-1.94(\mathrm{~m}, 2 \mathrm{H}), 1.79-1.73(\mathrm{~m}, 1 \mathrm{H}), 1.63-1.58(\mathrm{~m}$, $2 \mathrm{H}), 1.51-1.39(\mathrm{~m}, 2 \mathrm{H}), 1.24$ (br s, 2H), $1.20-1.07(\mathrm{~m}, 30 \mathrm{H}), 0.99(\mathrm{br} \mathrm{d}, J=7.2 \mathrm{~Hz}, 5 \mathrm{H}), 0.94-0.89(\mathrm{~m}, 5 \mathrm{H}), 0.68$ (br d, $J=6.8$ $\mathrm{Hz}, 3 \mathrm{H}), 0.63$ (br d, $J=6.2 \mathrm{~Hz}, 3 \mathrm{H}), 0.57$ (br d, $J=6.8 \mathrm{~Hz}, 3 \mathrm{H}), 0.5(\mathrm{br} \mathrm{d}, J=6.2 \mathrm{~Hz}, 3 \mathrm{H}$ ).

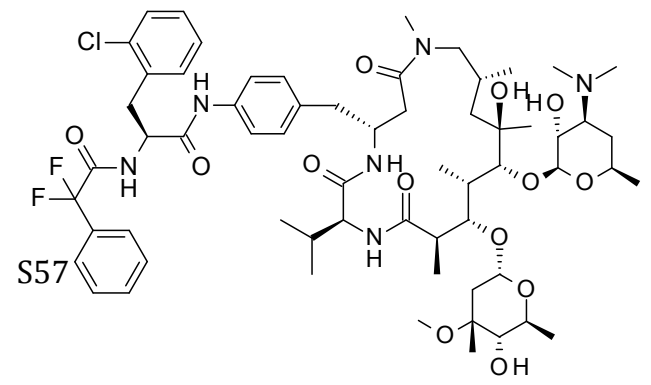

(2R)-3-(2-chlorophenyl)-2-[(2,2-difluoro-2-phenyl-acetyl)amino]- $N$-[4[[(2S,5S,10S,12S,13S,14R,15R,16S)-13-[(2R,3S,4R,6S)-4-(dimethylamino)-3hydroxy-6-methyl-tetrahydropyran-2-yl] oxy-12-hydroxy-15-[(2S,4S,5R,6R)5-hydroxy-4-methoxy-4,6-dimethyl-tetrahydropyran-2-yl]oxy-2-isopropyl8,10,12,14,16-pentamethyl-3,7,17-trioxo-1,4,8-triazacycloheptadec-5yl]methyl]phenyl]propanamide (40) 
Starting from 65 (42 mg, $0.12 \mathrm{mmol}$ ) and E-1a (100 mg, $0.12 \mathrm{mmol}$ ) title product (13 mg, yield $9 \%$, purity $99 \%$ ) was obtained by prep HPLC purification. ES ${ }^{+} \mathrm{m} / \mathrm{z} 1199.74[\mathrm{M}+\mathrm{H}]^{+} .{ }^{1} \mathrm{H}$ NMR $\left(500 \mathrm{MHz}, \mathrm{DMSO}-\mathrm{d}_{6}\right) \delta / \mathrm{ppm} 0.49(\mathrm{~d}, 3 \mathrm{H}, J=6.72), 0.56(\mathrm{~d}, 3 \mathrm{H}, J$ $=6.66), 0.61(\mathrm{~d}, 2 \mathrm{H}, J=6.42), 0.66(\mathrm{~d}, 2 \mathrm{H}, J=6.54), 0.88(\mathrm{~d}, 4 \mathrm{H}, J=6.48), 0.91(\mathrm{~d}, 2 \mathrm{H}, J=6.60), 0.97(\mathrm{~d}, 6 \mathrm{H}, J=7.26), 1.06-1.08$ $(\mathrm{m}, 6 \mathrm{H}), 1.09-1.1(\mathrm{~m}, 5 \mathrm{H}), 1.11-1.12(\mathrm{~m}, 10 \mathrm{H}), 1.14-1.15(\mathrm{~m}, 7 \mathrm{H}), 1.18(\mathrm{~s}, 2 \mathrm{H}), 1.22(\mathrm{~s}, 3 \mathrm{H}), 1.32-1.48(\mathrm{~m}, 3 \mathrm{H}), 1.59-1.63(\mathrm{~m}$, $2 \mathrm{H}), 1.72-1.77(\mathrm{~m}, 1 \mathrm{H}), 1.93-1.99(\mathrm{~m}, 3 \mathrm{H}), 2.06-2.1(\mathrm{~m}, 2 \mathrm{H}), 2.18-2.2(\mathrm{~m}, 1 \mathrm{H}), 2.23(\mathrm{~s}, 12 \mathrm{H}), 2.26(\mathrm{~s}, 1 \mathrm{H}), 2.34-2.38(\mathrm{~m}, 2 \mathrm{H})$, 2.54-2.61 (m, 4H), 2.66-2.71 (m, 1H), $2.75(\mathrm{~d}, 1 \mathrm{H}, J=11.1), 2.78(\mathrm{~s}, 4 \mathrm{H}), 2.84-2.9(\mathrm{~m}, 4 \mathrm{H}), 2.95-3.02(\mathrm{~m}, 2 \mathrm{H}), 3.03-3.12(\mathrm{~m}, 3 \mathrm{H})$, 3.15-3.24 (m, 12H), $3.43(\mathrm{~d}, 1 \mathrm{H}, J=4.98), 3.5(\mathrm{~d}, 1 \mathrm{H}, J=6.78), 3.63-3.67(\mathrm{~m}, 1 \mathrm{H}), 3.68(\mathrm{~s}, 1 \mathrm{H}), 3.82(\mathrm{~d}, 1 \mathrm{H}, J=9.24), 3.87(\mathrm{~s}$, $1 \mathrm{H}), 3.93-3.98(\mathrm{~m}, 1 \mathrm{H}), 3.98-4.05(\mathrm{~m}, 3 \mathrm{H}), 4.07-4.14(\mathrm{~m}, 2 \mathrm{H}), 4.2(\mathrm{~d}, 1 \mathrm{H}, J=10.68), 4.26(\mathrm{~d}, 2 \mathrm{H}, J=6.36), 4.43(\mathrm{~d}, 1 \mathrm{H}, J=7.32)$, 4.77-4.81 (m, 3H), $5.74(\mathrm{~s}, 1 \mathrm{H}), 7.09-7.12(\mathrm{~m}, 6 \mathrm{H}), 7.18-7.21(\mathrm{~m}, 3 \mathrm{H}), 7.23-7.27(\mathrm{~m}, 3 \mathrm{H}), 7.36(\mathrm{~d}, 2 \mathrm{H}, J=7.56), 7.4(\mathrm{~d}, 2 \mathrm{H}, J=$ 7.92), 7.43-7.46 (m, 9H), 7.49-7.53 (m, 2H), $8.1(\mathrm{~d}, 1 \mathrm{H}, 1 \mathrm{H}, J=7.14), 9.21-9.24(\mathrm{~m}, 1 \mathrm{H}), 10(\mathrm{~s}, 1 \mathrm{H})$.

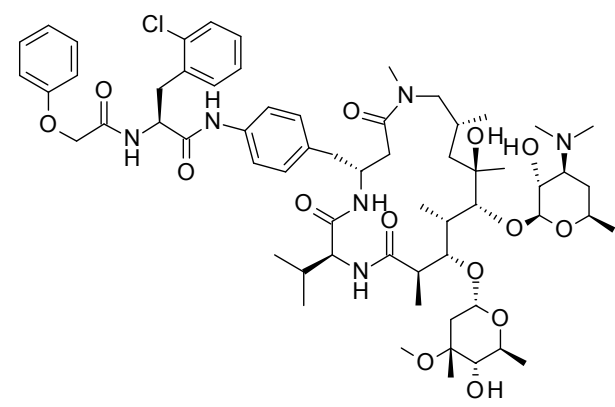

(2S)-3-(2-chlorophenyl)-N-[4-[[(2S,5R,10R,12R,13R,14S,15S,16R)-13-( $\beta$-Ddesosaminyl)oxy-12-hydroxy-15-( $\alpha$-L-cladinosyl)oxy-2-isopropyl8,10,12,14,16-pentamethyl-3,7,17-trioxo-1,4,8-triazacycloheptadec-5yl]methyl]phenyl]-2-[(2-phenoxyacetyl)amino]propanamide (45) Starting from (2S)-3-(2-chlorophenyl)-2-[(2phenoxyacetyl)amino]propanoic acid (43 mg, $0.128 \mathrm{mmol}$ ) and E-1a (100 mg, $0.116 \mathrm{mmol}$ ) title product (13 mg, yield $9.5 \%$, purity $92.98 \%$ ) was obtained by prep HPLC purification. $\mathrm{ES}^{+} \mathrm{m} / \mathrm{z} 1179.61[\mathrm{M}+\mathrm{H}]^{+} .{ }^{1} \mathrm{H}$ NMR $(500 \mathrm{MHz}$, DMSO-d $_{6}$ ) $\delta /$ ppm $10.03(\mathrm{~s}, 1 \mathrm{H}), 9.99(\mathrm{~s}, 1 \mathrm{H}), 8.40-8.27(\mathrm{~m}, 3 \mathrm{H}), 8.21(\mathrm{~s}, 2 \mathrm{H})$, 8.12 (br d, $J=8.9 \mathrm{~Hz}, 2 \mathrm{H}), 7.92$ (br d, $J=9.5 \mathrm{~Hz}, 2 \mathrm{H}), 7.49-7.37(\mathrm{~m}, 5 \mathrm{H}), 7.34-$ $7.19(\mathrm{~m}, 9 \mathrm{H}), 7.17-7.09(\mathrm{~m}, 3 \mathrm{H}), 7.01-6.91(\mathrm{~m}, 2 \mathrm{H}), 6.88(\mathrm{~d}, J=7.9 \mathrm{~Hz}, 3 \mathrm{H})$, 4.93-4.73 (m, 3H), 4.72-4.57 (m, 1H), $4.5(\mathrm{~s}, 3 \mathrm{H}), 4.49-4.43(\mathrm{~m}, 2 \mathrm{H}), 4.38(\mathrm{br} \mathrm{d}, J=6.7 \mathrm{~Hz}, 2 \mathrm{H}), 4.28(\mathrm{br} \mathrm{s}, 2 \mathrm{H}), 4.17-3.96(\mathrm{~m}$, 6H), 3.93-3.82 (m, 2H), 3.69-3.59 (m, 4H), 3.52 (br d, J=6.7 Hz, 3H), 3.46 (br d, J = 5.5 Hz, 3H), 3.40-3.31 (m, 8H), 3.25 (br d, $J=5.5 \mathrm{~Hz}, 2 \mathrm{H}), 3.23-3.21(\mathrm{~m}, 5 \mathrm{H}), 3.19(\mathrm{~s}, 2 \mathrm{H}), 3.13(\mathrm{br} \mathrm{dd}, J=14.3,8.5 \mathrm{~Hz}, 4 \mathrm{H}), 3.08(\mathrm{br} \mathrm{d}, J=7.9 \mathrm{~Hz}, 2 \mathrm{H}), 3.06-2.96(\mathrm{~m}, 3 \mathrm{H})$, 2.95-2.85 (m, 4H), 2.82-2.76 (m, 4H), 2.74-2.53 (m, 6H), 2.43-2.33 (m, 2H), 2.31-2.25 (m, 10H), 2.12-2.05 (m, 2H), 2.03-1.9 $(\mathrm{m}, 2 \mathrm{H}), 1.84-1.71(\mathrm{~m}, 1 \mathrm{H}), 1.64(\mathrm{br} \mathrm{d}, J=6.7 \mathrm{~Hz}, 2 \mathrm{H}), 1.57-1.37(\mathrm{~m}, 3 \mathrm{H}), 1.24(\mathrm{~s}, 6 \mathrm{H}), 1.21-1.07(\mathrm{~m}, 25 \mathrm{H}), 0.99(\mathrm{br} \mathrm{d}, J=7.3$ $\mathrm{Hz}, 6 \mathrm{H}), 0.96-0.85(\mathrm{~m}, 6 \mathrm{H}), 0.69(\mathrm{br} \mathrm{d}, J=6.7 \mathrm{~Hz}, 3 \mathrm{H}), 0.64-0.55(\mathrm{~m}, 5 \mathrm{H}), 0.52(\mathrm{br} \mathrm{d}, J=6.7 \mathrm{~Hz}, 3 \mathrm{H})$.

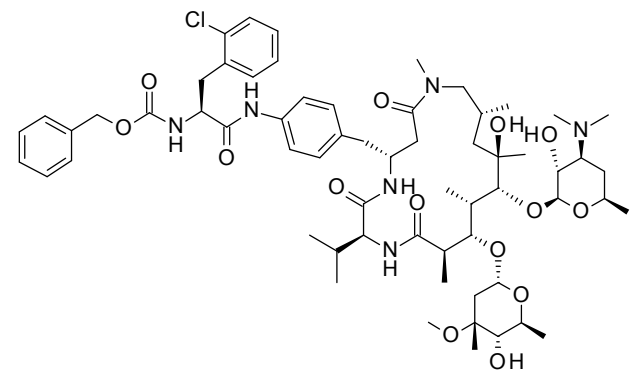

Benzyl- $N$-[(1S)-1-[(2-chlorophenyl $]$

methyl]-2-[4$[[(2 S, 5 R, 10 R, 12 R, 13 R, 14 S, 15 S, 16 R)-13-(\beta-D-d e s o s a m i n y l) o x y-12$-hydroxy15-( $\alpha$-L-cladinosyl)oxy-2-isopropyl-8,10,12,14,16-pentamethyl-3,7,17trioxo-1,4,8-triazacycloheptadec-5-yl]methyl]anilino]-2-oxoethyl]carbamate (46)

Starting from (2S)-2-(benzyloxycarbonylamino)-3-(2chlorophenyl)propanoic acid (43 mg, $0.127 \mathrm{mmol}$ ) and E-1a (100 mg, 0.116 mmol) title product (74 mg, yield $54 \%$, purity $98.23 \%$ ) was obtained by prep HPLC purification.

$\mathrm{ES}^{+} \mathrm{m} / \mathrm{z} 1179.58[\mathrm{M}+\mathrm{H}]^{+} .{ }^{1} \mathrm{H}$ NMR $\left(500 \mathrm{MHz}, \mathrm{DMSO}-\mathrm{d}_{6}\right) \delta / \mathrm{ppm} 9.92(\mathrm{~s}, 1 \mathrm{H})$, $9.88(\mathrm{~s}, 1 \mathrm{H}), 8.1(\mathrm{br} \mathrm{d}, J=8.9 \mathrm{~Hz}, 1 \mathrm{H}), 7.9(\mathrm{br} \mathrm{d}, J=8.9 \mathrm{~Hz}, 1 \mathrm{H}), 7.73-7.65(\mathrm{~m}, 2 \mathrm{H}), 7.46(\mathrm{br} \mathrm{d}, J=8.2 \mathrm{~Hz}, 1 \mathrm{H}), 7.41(\mathrm{br} \mathrm{t}, J=8.1$ $\mathrm{Hz}, 5 \mathrm{H}), 7.37-7.3(\mathrm{~m}, 6 \mathrm{H}), 7.30-7.16(\mathrm{~m}, 12 \mathrm{H}), 7.14-7.07(\mathrm{~m}, 4 \mathrm{H}), 5.04-4.91(\mathrm{~m}, 4 \mathrm{H}), 4.78(\mathrm{br} \mathrm{d}, J=4.6 \mathrm{~Hz}, 1 \mathrm{H}), 4.62(\mathrm{br} \mathrm{d}, J=$ $4 \mathrm{~Hz}, 1 \mathrm{H}), 4.53-4.46(\mathrm{~m}, 2 \mathrm{H}), 4.44(\mathrm{br} \mathrm{d}, J=7.3 \mathrm{~Hz}, 1 \mathrm{H}), 4.36(\mathrm{br} \mathrm{d}, J=7.3 \mathrm{~Hz}, 1 \mathrm{H}), 4.28(\mathrm{~d}, J=7.6 \mathrm{~Hz}, 1 \mathrm{H}), 4.28-4.24(\mathrm{~m}, 1 \mathrm{H})$, $4.22(\mathrm{~d}, J=8.2 \mathrm{~Hz}, 1 \mathrm{H}), 4.16-4.08(\mathrm{~m}, 3 \mathrm{H}), 4.07-3.94(\mathrm{~m}, 5 \mathrm{H}), 3.88(\mathrm{~s}, 1 \mathrm{H}), 3.83(\mathrm{br} \mathrm{d}, J=7.6 \mathrm{~Hz}, 1 \mathrm{H}), 3.69(\mathrm{~s}, 1 \mathrm{H}), 3.66(\mathrm{br} \mathrm{dq}$, $J=10.7,6.1 \mathrm{~Hz}, 1 \mathrm{H}), 3.62-3.55(\mathrm{~m}, 1 \mathrm{H}), 3.51(\mathrm{br} \mathrm{d}, J=7 \mathrm{~Hz}, 1 \mathrm{H}), 3.45(\mathrm{br} \mathrm{d}, J=5.2 \mathrm{~Hz}, 1 \mathrm{H}), 3.24(\mathrm{br} \mathrm{d}, J=8.5 \mathrm{~Hz}, 2 \mathrm{H}), 3.2(\mathrm{~s}$, 4H), 3.18 (s, 2H), 3.17-3.11 (m, 2H), 3.10-3.04 (m, 2H), 3.01 (br dd, J=14.2, $9 \mathrm{~Hz}, 3 \mathrm{H}), 2.96(\mathrm{br} \mathrm{s}, 1 \mathrm{H}), 2.91$ (br t, J = 9.2 Hz, 2H), $2.88(\mathrm{~s}, 2 \mathrm{H}), 2.79(\mathrm{~s}, 4 \mathrm{H}), 2.76(\mathrm{br} \mathrm{d}, J=8.5 \mathrm{~Hz}, 1 \mathrm{H}), 2.69(\mathrm{br} \mathrm{dd}, J=13.4,6.7 \mathrm{~Hz}, 1 \mathrm{H}), 2.63-2.53(\mathrm{~m}, 5 \mathrm{H}), 2.48-2.41(\mathrm{~m}$, $3 \mathrm{H}), 2.37(\mathrm{dt}, J=14.2,7.2 \mathrm{~Hz}, 2 \mathrm{H}), 2.26(\mathrm{~d}, J=15 \mathrm{~Hz}, 2 \mathrm{H}), 2.22(\mathrm{~s}, 11 \mathrm{H}), 2.15-2.07(\mathrm{~m}, 1 \mathrm{H}), 2.04-1.91(\mathrm{~m}, 3 \mathrm{H}), 1.76(\mathrm{dq}, J=$ 13.7, $6.6 \mathrm{~Hz}, 1 \mathrm{H}$ ), 1.6 (br d, $J=7.3 \mathrm{~Hz}, 2 \mathrm{H}), 1.48$ (br dd, $J=14.6,4.9 \mathrm{~Hz}, 1 \mathrm{H}), 1.46-1.4(\mathrm{~m}, 1 \mathrm{H}), 1.38$ (br s, $1 \mathrm{H}), 1.28-1.21(\mathrm{~m}$, $3 \mathrm{H}), 1.20-1.05(\mathrm{~m}, 33 \mathrm{H}), 0.98(\mathrm{br} \mathrm{d}, J=7 \mathrm{~Hz}, 6 \mathrm{H}), 0.92(\mathrm{br} \mathrm{d}, J=6.7 \mathrm{~Hz}, 2 \mathrm{H}), 0.9(\mathrm{br} \mathrm{d}, J=6.4 \mathrm{~Hz}, 4 \mathrm{H}), 0.68(\mathrm{br} \mathrm{d}, J=6.4 \mathrm{~Hz}, 2 \mathrm{H}$ ), $0.62(\mathrm{br} \mathrm{d}, J=6.7 \mathrm{~Hz}, 2 \mathrm{H}), 0.57(\mathrm{br} \mathrm{d}, J=6.4 \mathrm{~Hz}, 4 \mathrm{H}), 0.51(\mathrm{br} \mathrm{d}, J=6.4 \mathrm{~Hz}, 4 \mathrm{H}$ ). 


\section{General procedure for compounds 28-55}
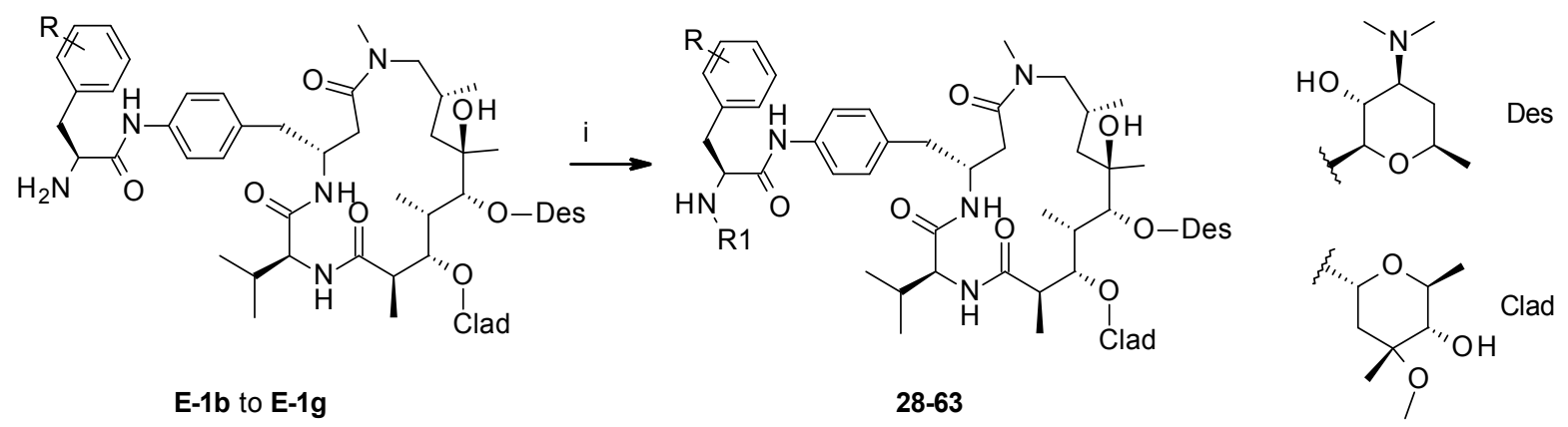

Scheme S8. Synthesis of compounds 28-63

\section{Amide synthesis}

To a solution of E-1b (1 eq) in dry DMF, HATU (1.4 eq), DIPEA (1.7 eq) and corresponding carboxylic acid (1 eq) were added and stirred at room temperature for $1 \mathrm{~h}$. After reaction was complete, DMF was evaporated and then extracted with water and DCM. Organic layer was dried over sodium sulfate, filtered and evaporated to dryness. The crude product was purified by prep HPLC purification (extended A, high $\mathrm{pH}$ ) or by column chromatography using DCM:MeOH: $\mathrm{NH}_{4} \mathrm{OH}=10: 1: 0.1$ as eluent to get title compound.

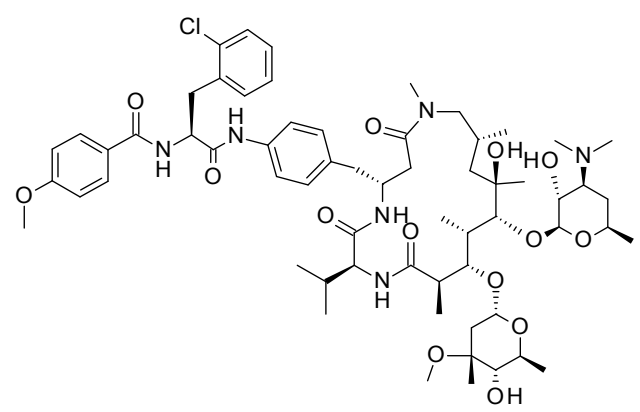

$N$-[(1S)-1-[(2-chlorophenyl)methyl]-2-[4-

[[(2S,5R,10R,12R,13R,14S,15S,16R)-13-( $\beta$-D-desosaminyl)oxy-12-hydroxy15 -( $\alpha$-L-cladinosyl)oxy-2-isopropyl-8,10,12,14,16-pentamethyl-3,7,17trioxo-1,4,8-triazacycloheptadec-5-yl]methyl]anilino]-2-oxo-ethyl]-4methoxy-benzamide (28)

Starting from 4-methoxybenzoic acid $(10.2 \mathrm{mg}, 0.067 \mathrm{mmol})$ and E-1b $(70$ $\mathrm{mg}, 0.067 \mathrm{mmol}$ ) title product ( $48 \mathrm{mg}$, yield $61 \%$, purity $99 \%$ ) was obtained by prep HPLC purification. ES ${ }^{+} \mathrm{m} / \mathrm{z} 1179.6[\mathrm{M}+\mathrm{H}]^{+} .{ }^{1} \mathrm{H}$ NMR (500 MHz, DMSO$\left.\mathrm{d}_{6}\right) \delta / \mathrm{ppm} 9.99(\mathrm{~s}, 1 \mathrm{H}), 9.96(\mathrm{~s}, 1 \mathrm{H}), 8.60-8.56(\mathrm{~m}, 3 \mathrm{H}), 8.11(\mathrm{br} \mathrm{d}, J=8.5 \mathrm{~Hz}$, $2 \mathrm{H}), 7.9$ (br d, $J=9.2 \mathrm{~Hz}, 2 \mathrm{H}), 7.84(\mathrm{~d}, J=7.9 \mathrm{~Hz}, 3 \mathrm{H}), 7.50-7.4(\mathrm{~m}, 8 \mathrm{H}), 7.28$ (br d, $J=8.5 \mathrm{~Hz}, 2 \mathrm{H}), 7.25-7.22(\mathrm{~m}, 2 \mathrm{H}), 7.21(\mathrm{~d}, J=4 \mathrm{~Hz}, 2 \mathrm{H}), 7.14-7.1(\mathrm{~m}$, $3 \mathrm{H}), 6.99(\mathrm{~d}, J=7.9 \mathrm{~Hz}, 3 \mathrm{H}), 4.93(\mathrm{td}, J=8.4,6.1 \mathrm{~Hz}, 2 \mathrm{H}), 4.79(\mathrm{br} \mathrm{d}, J=4.9 \mathrm{~Hz}$, $2 \mathrm{H}), 4.63(\mathrm{br} \mathrm{d}, J=4.3 \mathrm{~Hz}, 2 \mathrm{H}), 4.45(\mathrm{~d}, J=7.3 \mathrm{~Hz}, 2 \mathrm{H}), 4.37(\mathrm{~d}, J=7 \mathrm{~Hz}, 2 \mathrm{H}), 4.29(\mathrm{~d}, J=7.6 \mathrm{~Hz}, 2 \mathrm{H}), 4.23(\mathrm{~d}, J=8.2 \mathrm{~Hz}, 2 \mathrm{H})$, 4.17-4.08 (m, 2H), 4.07-4 (m, 4H), 4-3.94 (m, 2H), 3.89 (s, 1H), 3.85-3.78 (m, 6H), 3.73-3.65 (m, 2H), 3.59 (br dd, $J=11.4$, $6.3 \mathrm{~Hz}, 2 \mathrm{H}), 3.51$ (br d, $J=7 \mathrm{~Hz}, 2 \mathrm{H}), 3.48-3.43(\mathrm{~m}, 2 \mathrm{H}), 3.31-3.23(\mathrm{~m}, 4 \mathrm{H}), 3.22-3.17(\mathrm{~m}, 5 \mathrm{H}), 3.13-2.96(\mathrm{~m}, 5 \mathrm{H}), 2.93-2.85$ (m, 4H), $2.79(\mathrm{~s}, 5 \mathrm{H}), 2.72-2.53(\mathrm{~m}, 5 \mathrm{H}), 2.50-2.34(\mathrm{~m}, 5 \mathrm{H}), 2.28-2.2(\mathrm{~m}, 12 \mathrm{H}), 2.13-2.04(\mathrm{~m}, 2 \mathrm{H}), 2.03-1.94(\mathrm{~m}, 2 \mathrm{H}), 1.77(\mathrm{dq}$, $J=13.8,6.9 \mathrm{~Hz}, 2 \mathrm{H}), 1.6(\mathrm{br} \mathrm{d}, J=7 \mathrm{~Hz}, 2 \mathrm{H}), 1.52-1.37(\mathrm{~m}, 2 \mathrm{H}), 1.30-1.22(\mathrm{~m}, 2 \mathrm{H}), 1.21-1.06(\mathrm{~m}, 30 \mathrm{H}), 0.99(\mathrm{br} \mathrm{d}, J=7.3 \mathrm{~Hz}$, $5 \mathrm{H}), 0.95-0.88(\mathrm{~m}, 5 \mathrm{H}), 0.7(\mathrm{~d}, J=6.7 \mathrm{~Hz}, 3 \mathrm{H}), 0.64(\mathrm{br} \mathrm{d}, J=6.4 \mathrm{~Hz}, 3 \mathrm{H}), 0.58(\mathrm{~d}, J=6.7 \mathrm{~Hz}, 3 \mathrm{H}), 0.52(\mathrm{~d}, J=6.7 \mathrm{~Hz}, 3 \mathrm{H})$.

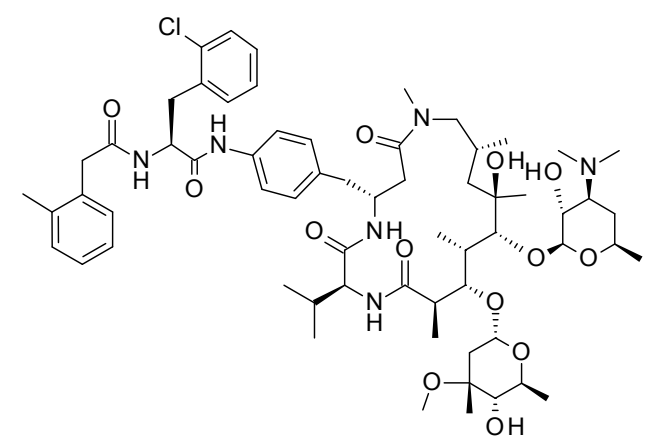

(2S)-3-(2-chlorophenyl)- $N$-[4-[[(2S,5R,10R,12R,13R,14S,15S,16R)-13-( $\beta$ D-desosaminyl)oxy-12-hydroxy-15-( $\alpha$-L-cladinosyl)oxy-2-isopropyl8,10,12,14,16-pentamethyl-3,7,17-trioxo-1,4,8-triazacycloheptadec-5yl]methyl]phenyl]-2-[[2-(o-tolyl)acetyl]amino]propenamide (29)

Starting from 2-(o-tolyl)acetic acid $(10.1 \mathrm{mg}, 0.067 \mathrm{mmol})$ and E-1b $(70 \mathrm{mg}$, $0.067 \mathrm{mmol}$ ) title product ( $25 \mathrm{mg}$, yield $31 \%$, purity $96.27 \%$ ) was obtained by prep HPLC purification. $\mathrm{ES}^{+} \mathrm{m} / \mathrm{z} 1177.41[\mathrm{M}+\mathrm{H}]^{+}$. Two sets of signals in the NMR (most likely conformers). ${ }^{1} \mathrm{H}$ NMR $\left(500 \mathrm{MHz}\right.$, DMSO-d $\left.\mathrm{d}_{6}\right) \delta / \mathrm{ppm}$ $9.98(\mathrm{~s}, 1 \mathrm{H}), 9.94(\mathrm{~s}, 1 \mathrm{H}), 8.41-8.34(\mathrm{~m}, 3 \mathrm{H}), 8.16-8.09(\mathrm{~m}, 2 \mathrm{H}), 7.94-7.89$ $(\mathrm{m}, 1 \mathrm{H}), 7.46(\mathrm{~d}, J=8.5 \mathrm{~Hz}, 2 \mathrm{H}), 7.44-7.38(\mathrm{~m}, 5 \mathrm{H}), 7.34-7.28(\mathrm{~m}, 4 \mathrm{H}), 7.26-$ $7.19(\mathrm{~m}, 4 \mathrm{H}), 7.15-7.08(\mathrm{~m}, 9 \mathrm{H}), 7.07-7.02(\mathrm{~m}, 4 \mathrm{H}), 5.04-4.92(\mathrm{~m}, 1 \mathrm{H}) 4.82-$ $4.77(\mathrm{~m}, 2 \mathrm{H}), 4.68-4.61(\mathrm{~m}, 1 \mathrm{H}), 4.47(\mathrm{br} \mathrm{d}, J=7 \mathrm{~Hz}, 2 \mathrm{H}), 4.39$ (br d, $J=7.3$ $\mathrm{Hz}, 2 \mathrm{H}), 4.29(\mathrm{~d}, J=7.6 \mathrm{~Hz}, 2 \mathrm{H}), 4.23(\mathrm{~d}, J=8.2 \mathrm{~Hz}, 2 \mathrm{H}), 4.16-4.09(\mathrm{~m}, 3 \mathrm{H})$, 4.05 (br d, $J=7 \mathrm{~Hz}, 3 \mathrm{H}), 4.01-3.95(\mathrm{~m}, 1 \mathrm{H}), 3.94-3.89(\mathrm{~m}, 1 \mathrm{H}), 3.84(\mathrm{br} \mathrm{d}, J=7.9 \mathrm{~Hz}, 2 \mathrm{H}), 3.69(\mathrm{~s}, 2 \mathrm{H}), 3.67-3.63(\mathrm{~m}, 2 \mathrm{H}), 3.52$ (br d, $J=7.3 \mathrm{~Hz}, 3 \mathrm{H}), 3.48(\mathrm{~d}, J=3.4 \mathrm{~Hz}, 4 \mathrm{H}), 3.46-3.42(\mathrm{~m}, 1 \mathrm{H}), 3.21(\mathrm{~s}, 3 \mathrm{H}), 3.20-3.18(\mathrm{~m}, 2 \mathrm{H}), 3.18-3.12(\mathrm{~m}, 2 \mathrm{H}), 3.08-3.03$ (m, 2H), 3.02-2.94 (m, 1H), 2.93-2.88 (m, 3H), $2.8(\mathrm{~s}, 3 \mathrm{H}), 2.74-2.66(\mathrm{~m}, 2 \mathrm{H}), 2.65-2.58(\mathrm{~m}, 5 \mathrm{H}), 2.40-2.35(\mathrm{~m}, 2 \mathrm{H}), 2.27(\mathrm{br}$ $\mathrm{d}, J=15 \mathrm{~Hz}, 4 \mathrm{H}), 2.23-2.19(\mathrm{~m}, 1 \mathrm{H}), 2.13(\mathrm{~s}, 5 \mathrm{H}), 2.03-1.94(\mathrm{~m}, 2 \mathrm{H}), 1.81-1.74(\mathrm{~m}, 1 \mathrm{H}), 1.54-1.45(\mathrm{~m}, 2 \mathrm{H}), 1.28-1.23(\mathrm{~m}, 5 \mathrm{H})$, $1.22-1.19(\mathrm{~m}, 4 \mathrm{H}), 1.19-1.16(\mathrm{~m}, 10 \mathrm{H}), 1.15-1.07(\mathrm{~m}, 21 \mathrm{H}), 0.99(\mathrm{br} \mathrm{d}, J=7 \mathrm{~Hz}, 6 \mathrm{H}), 0.94-0.89(\mathrm{~m}, 6 \mathrm{H}), 0.71-0.66(\mathrm{~m}, 3 \mathrm{H})$, $0.64-0.59(\mathrm{~m}, 3 \mathrm{H}), 0.57$ (br d, $J=6.4 \mathrm{~Hz}, 3 \mathrm{H}), 0.51(\mathrm{br} \mathrm{d}, J=6.7 \mathrm{~Hz}, 3 \mathrm{H})$. 


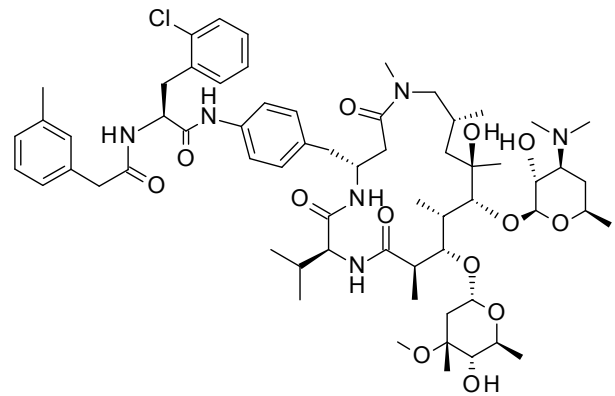

(2S)-3-(2-chlorophenyl)- $N$-[4-[[(2S,5R,10R,12R,13R,14S,15S,16R)-13- ( $\beta$-Ddesosaminyl)oxy-12-hydroxy-15-( $\alpha$-L-cladinosyl)oxy-2-isopropyl8,10,12,14,16-pentamethyl-3,7,17-trioxo-1,4,8-triazacycloheptadec-5yl]methyl]phenyl]-2-[[2-(m-tolyl)acetyl]amino]propanamide (30) Starting from 2 - ( $m$-tolyl)acetic acid $(10 \mathrm{mg}, 0.067 \mathrm{mmol})$ and $\mathbf{E - 1 b}(70 \mathrm{mg}$, $0.067 \mathrm{mmol}$ ) title product ( $46 \mathrm{mg}$, yield $58 \%$, purity $98.6 \%$ ) was obtained by prep HPLC purification. $\mathrm{ES}^{+} \mathrm{m} / \mathrm{z} 1177.56[\mathrm{M}+\mathrm{H}]^{+} .{ }^{1} \mathrm{H}$ NMR $(500 \mathrm{MHz}$, DMSO$\left.\mathrm{d}_{6}\right) \delta / \mathrm{ppm} 9.96(\mathrm{~s}, 1 \mathrm{H}), 9.92(\mathrm{~s}, 1 \mathrm{H}), 8.53-8.35(\mathrm{~m}, 3 \mathrm{H}), 8.09(\mathrm{br} \mathrm{d}, J=8.9 \mathrm{~Hz}$, $2 \mathrm{H}), 7.89$ (br d, $J=9.2 \mathrm{~Hz}, 2 \mathrm{H}), 7.48-7.35(\mathrm{~m}, 6 \mathrm{H}), 7.31-7.25(\mathrm{~m}, 4 \mathrm{H}), 7.24-7.2$ (m, 2H), 7.19-7.14 (m, 2H), 7.14-7.07 (m, 5H), 7.01-6.91 (m, 6H), 4.81-4.7 (m, $3 \mathrm{H}), 4.62(\mathrm{br} \mathrm{d}, J=4 \mathrm{~Hz}, 2 \mathrm{H}), 4.44(\mathrm{br} \mathrm{d}, J=7.3 \mathrm{~Hz}, 2 \mathrm{H}), 4.36(\mathrm{br} \mathrm{d}, J=7.3 \mathrm{~Hz}$, $2 \mathrm{H}), 4.28(\mathrm{~d}, J=7.6 \mathrm{~Hz}, 2 \mathrm{H}), 4.27-4.24(\mathrm{~m}, 1 \mathrm{H}), 4.22(\mathrm{~d}, J=8.2 \mathrm{~Hz}, 2 \mathrm{H}), 4.12(\mathrm{br} \mathrm{s}, 3 \mathrm{H}), 4.07-3.98(\mathrm{~m}, 4 \mathrm{H}), 3.96(\mathrm{br} \mathrm{t}, J=7.5 \mathrm{~Hz}$, $1 \mathrm{H}), 3.88(\mathrm{~s}, 1 \mathrm{H}), 3.82(\mathrm{br} \mathrm{d}, J=7.9 \mathrm{~Hz}, 2 \mathrm{H}), 3.69(\mathrm{~s}, 1 \mathrm{H}), 3.66(\mathrm{br} \mathrm{dq}, J=10.4,6.4 \mathrm{~Hz}, 1 \mathrm{H}), 3.58(\mathrm{br} \mathrm{dq}, J=11.9,7.3 \mathrm{~Hz}, 1 \mathrm{H}), 3.5$ (br d, $J=6.7 \mathrm{~Hz}, 1 \mathrm{H}), 3.46-3.43(\mathrm{~m}, 1 \mathrm{H}), 3.45-3.36(\mathrm{~m}, 3 \mathrm{H}), 3.24$ (br s, 3H), $3.2(\mathrm{~s}, 3 \mathrm{H}), 3.18(\mathrm{~s}, 3 \mathrm{H}), 3.17-3.1(\mathrm{~m}, 2 \mathrm{H}), 3.10-$ $2.99(\mathrm{~m}, 4 \mathrm{H}), 2.96(\mathrm{br} \mathrm{d}, J=11 \mathrm{~Hz}, 1 \mathrm{H}), 2.92-2.88(\mathrm{~m}, 1 \mathrm{H}), 2.89-2.87(\mathrm{~m}, 1 \mathrm{H}), 2.78(\mathrm{~s}, 3 \mathrm{H}), 2.64-2.54(\mathrm{~m}, 4 \mathrm{H}), 2.48-2.41(\mathrm{~m}$, $2 \mathrm{H}), 2.41-2.31(\mathrm{~m}, 2 \mathrm{H}), 2.26(\mathrm{br} \mathrm{d}, J=15 \mathrm{~Hz}, 2 \mathrm{H}), 2.23(\mathrm{~s}, 6 \mathrm{H}), 2.22(\mathrm{~s}, 8 \mathrm{H}), 2.14-2.07(\mathrm{~m}, 2 \mathrm{H}), 1.97(\mathrm{dt}, J=13.5,6.8 \mathrm{~Hz}, 2 \mathrm{H})$, $1.76(\mathrm{dq}, J=13.6,6.8 \mathrm{~Hz}, 2 \mathrm{H}), 1.6(\mathrm{br} \mathrm{d}, J=7.3 \mathrm{~Hz}, 2 \mathrm{H}), 1.47$ (br dd, $J=14.8,5 \mathrm{~Hz}, 2 \mathrm{H}), 1.23(\mathrm{br} \mathrm{s}, 2 \mathrm{H}), 1.20-1.05(\mathrm{~m}, 29 \mathrm{H}), 0.98$ (br d, $J=7.3 \mathrm{~Hz}, 6 \mathrm{H}), 0.92(\mathrm{br} \mathrm{d}, J=6.7 \mathrm{~Hz}, 2 \mathrm{H}), 0.9(\mathrm{br} \mathrm{d}, J=6.4 \mathrm{~Hz}, 4 \mathrm{H}), 0.68(\mathrm{br} \mathrm{d}, J=6.7 \mathrm{~Hz}, 3 \mathrm{H}), 0.62(\mathrm{br} \mathrm{d}, J=6.7 \mathrm{~Hz}, 3 \mathrm{H})$, $0.57(\mathrm{br} \mathrm{d}, J=6.7 \mathrm{~Hz}, 3 \mathrm{H}), 0.49(\mathrm{br} \mathrm{d}, J=6.7 \mathrm{~Hz}, 3 \mathrm{H})$.

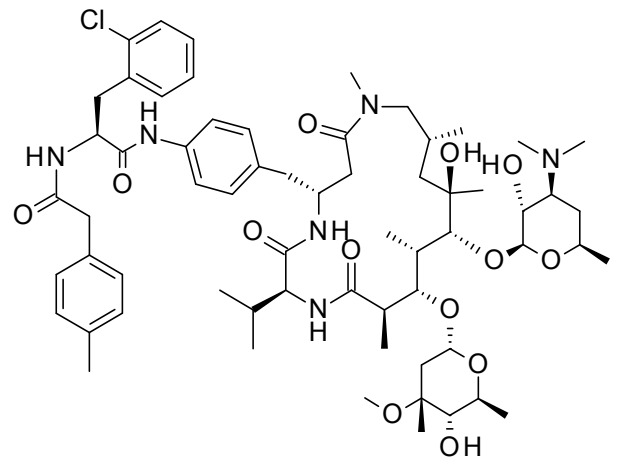

(2S)-3-(2-chlorophenyl)- $N$-[4-[[(2S,5R,10R,12R,13R,14S,15S,16R)-13-( $\beta$-Ddesosaminyl)oxy-12-hydroxy-15-( $\alpha$-L-cladinosyl)oxy-2-isopropyl8,10,12,14,16-pentamethyl-3,7,17-trioxo-1,4,8-triazacycloheptadec-5yl]methyl]phenyl]-2-[[2-(p-tolyl)acetyl]amino]propanamide (31)

Starting from 2-(p-tolyl)acetic acid $(10 \mathrm{mg}, 0.067 \mathrm{mmol})$ and E-1b $(70 \mathrm{mg}$, $0.067 \mathrm{mmol}$ ) title product (50 mg, yield $63 \%$, purity $97.96 \%$ ) was obtained by prep HPLC purification. ES $\mathrm{m} / \mathrm{z} 1177.55[\mathrm{M}+\mathrm{H}]^{+} .{ }^{1} \mathrm{H}$ NMR (500 MHz, DMSO$\left.\mathrm{d}_{6}\right) \delta /$ ppm $9.96(\mathrm{~s}, 1 \mathrm{H}), 9.92(\mathrm{~s}, 1 \mathrm{H}), 8.42(\mathrm{t}, J=7.4 \mathrm{~Hz}, 3 \mathrm{H}), 8.1(\mathrm{br} \mathrm{d}, J=8.9 \mathrm{~Hz}$, $2 \mathrm{H}), 7.9(\mathrm{br} \mathrm{d}, J=9.2 \mathrm{~Hz}, 2 \mathrm{H}), 7.47-7.38(\mathrm{~m}, 6 \mathrm{H}), 7.31-7.14(\mathrm{~m}, 8 \mathrm{H}), 7.13-7.09$ (m, 3H), 7.06-7.02 (m, 7H), 4.82-4.74 (m, 3H), $4.63(\mathrm{br} \mathrm{d}, J=4.3 \mathrm{~Hz}, 2 \mathrm{H}), 4.45$ (d, $J=7.3 \mathrm{~Hz}, 2 \mathrm{H}), 4.37$ (br d, $J=7.3 \mathrm{~Hz}, 2 \mathrm{H}), 4.29$ (d, $J=7.6 \mathrm{~Hz}, 2 \mathrm{H}), 4.23(\mathrm{~d}, J$ $=8.2 \mathrm{~Hz}, 1 \mathrm{H}), 4.15-3.95(\mathrm{~m}, 10 \mathrm{H}), 3.92-3.87(\mathrm{~m}, 1 \mathrm{H}), 3.84(\mathrm{br} \mathrm{d}, J=7 \mathrm{~Hz}, 2 \mathrm{H})$, 3.7 (s, 1H), 3.67 (br dd, $J=10.5,6.6 \mathrm{~Hz}, 2 \mathrm{H}), 3.6(\mathrm{br} \mathrm{dd}, J=11.6,7 \mathrm{~Hz}, 2 \mathrm{H}), 3.52$ (br d, $J=6.7 \mathrm{~Hz}, 2 \mathrm{H}), 3.48-3.43(\mathrm{~m}, 2 \mathrm{H}), 3.4(\mathrm{~d}, J=5.8 \mathrm{~Hz}, 4 \mathrm{H}), 3.21(\mathrm{~s}, 3 \mathrm{H}), 3.20-3.18(\mathrm{~m}, 3 \mathrm{H}), 3.14(\mathrm{~d}, J=6.1 \mathrm{~Hz}, 2 \mathrm{H}), 3.11-$ $2.95(\mathrm{~m}, 5 \mathrm{H}), 2.93-2.86(\mathrm{~m}, 3 \mathrm{H}), 2.8(\mathrm{~s}, 4 \mathrm{H}), 2.77-2.65(\mathrm{~m}, 2 \mathrm{H}), 2.64-2.55(\mathrm{~m}, 5 \mathrm{H}), 2.48-2.33(\mathrm{~m}, 3 \mathrm{H}), 2.24(\mathrm{~d}, J=12.2 \mathrm{~Hz}$, $16 \mathrm{H}), 2.28-2.21(\mathrm{~m}, 1 \mathrm{H}), 2.16-2.09(\mathrm{~m}, 1 \mathrm{H}), 2.08(\mathrm{~s}, 1 \mathrm{H}), 1.98(\mathrm{dt}, J=13.4,6.7 \mathrm{~Hz}, 2 \mathrm{H}), 1.80-1.74(\mathrm{~m}, 1 \mathrm{H}), 1.61$ (br d, $J=7.3$ $\mathrm{Hz}, 2 \mathrm{H}), 1.52-1.34(\mathrm{~m}, 3 \mathrm{H}), 1.32-1.22(\mathrm{~m}, 3 \mathrm{H}), 1.21-1.15(\mathrm{~m}, 12 \mathrm{H}), 1.15-1.06(\mathrm{~m}, 18 \mathrm{H}), 0.99$ (br d, $J=7.3 \mathrm{~Hz}, 5 \mathrm{H}), 0.94-0.89$ $(\mathrm{m}, 4 \mathrm{H}), 0.69(\mathrm{~d}, J=6.7 \mathrm{~Hz}, 3 \mathrm{H}), 0.63(\mathrm{br} \mathrm{d}, J=6.7 \mathrm{~Hz}, 3 \mathrm{H}), 0.60-0.55(\mathrm{~m}, 3 \mathrm{H}), 0.5(\mathrm{~d}, J=7 \mathrm{~Hz}, 3 \mathrm{H})$.

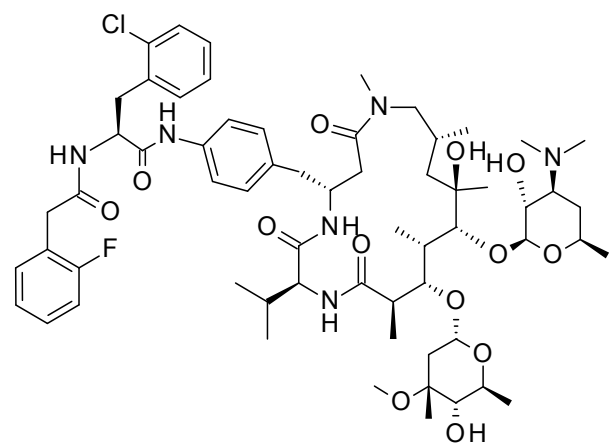

(2S)-3-(2-chlorophenyl)- $N$-[4-[[(2S,5R,10R,12R,13R,14S,15S,16R)-13-( $\beta$-Ddesosaminyl)oxy-12-hydroxy-15-( $\alpha$-L-cladinosyl)oxy-2-isopropyl8,10,12,14,16-pentamethyl-3,7,17-trioxo-1,4,8-triazacycloheptadec-5yl]methyl]phenyl]-2-[[2-(2-fluorophenyl)acetyl]amino]propenamide (32) Starting from 3-fluorophenylacetic acid (11 $\mathrm{mg}, 0.73 \mathrm{mmol})$ and $\mathbf{E}-\mathbf{1 b}(60 \mathrm{mg}$, $0.057 \mathrm{mmol}$ ) title product ( $25 \mathrm{mg}$, yield $37 \%$, purity $99.91 \%$ ) was obtained by prep HPLC purification. ES+ $\mathrm{m} / \mathrm{z} 1181.61[\mathrm{M}+\mathrm{H}]^{+} .{ }^{1} \mathrm{H}$ NMR $(600 \mathrm{MHz}$, DMSO$\left.\mathrm{d}_{6}\right) \delta / \mathrm{ppm} 9.98(\mathrm{~s}, 1 \mathrm{H}), 9.94(\mathrm{~s}, 1 \mathrm{H}), 8.55-8.49(\mathrm{~m}, 3 \mathrm{H}), 8.13-8.1(\mathrm{~m}, 1 \mathrm{H}), 7.88$ (br d, $J=1.7 \mathrm{~Hz}, 1 \mathrm{H}), 7.45(\mathrm{~d}, J=8.1 \mathrm{~Hz}, 3 \mathrm{H}), 7.43-7.39(\mathrm{~m}, 8 \mathrm{H}), 7.31(\mathrm{br} \mathrm{d}, J=$ $7.5 \mathrm{~Hz}, 2 \mathrm{H}), 7.30-7.28(\mathrm{~m}, 2 \mathrm{H}), 7.26-7.2(\mathrm{~m}, 9 \mathrm{H}), 7.19(\mathrm{~s}, 1 \mathrm{H}), 7.14-7.1(\mathrm{~m}$, $11 \mathrm{H}), 7.09(\mathrm{~s}, 1 \mathrm{H}), 4.78(\mathrm{br} \mathrm{d}, J=6.8 \mathrm{~Hz}, 2 \mathrm{H}), 4.45(\mathrm{~d}, J=7.2 \mathrm{~Hz}, 1 \mathrm{H}), 4.31(\mathrm{~d}, J$ $=7.9 \mathrm{~Hz}, 2 \mathrm{H}), 4.17-4.12(\mathrm{~m}, 3 \mathrm{H}), 4.08-4.06(\mathrm{~m}, 3 \mathrm{H}), 4.05-3.99(\mathrm{~m}, 4 \mathrm{H}), 3.92-$ $3.89(\mathrm{~m}, 1 \mathrm{H}), 3.86-3.79(\mathrm{~m}, 2 \mathrm{H}), 3.73-3.69(\mathrm{~m}, 2 \mathrm{H}), 3.57-3.49(\mathrm{~m}, 12 \mathrm{H}), 3.22-$ $3.18(\mathrm{~m}, 12 \mathrm{H}), 3.16(\mathrm{br} \mathrm{d}, J=5.9 \mathrm{~Hz}, 2 \mathrm{H}), 3.07(\mathrm{br} \mathrm{s}, 1 \mathrm{H}), 3.06-3.05(\mathrm{~m}, 3 \mathrm{H}), 3-2.94(\mathrm{~m}, 3 \mathrm{H}), 2.89(\mathrm{br} \mathrm{s}, 2 \mathrm{H}), 2.79(\mathrm{~s}, 5 \mathrm{H}), 2.64-$ $2.56(\mathrm{~m}, 8 \mathrm{H}), 2.29-2.25(\mathrm{~m}, 4 \mathrm{H}), 2.23(\mathrm{~s}, 11 \mathrm{H}), 2.13-2.08(\mathrm{~m}, 2 \mathrm{H}), 2.01-1.95(\mathrm{~m}, 4 \mathrm{H}), 1.81-1.74(\mathrm{~m}, 2 \mathrm{H}), 1.63-1.59(\mathrm{~m}, 2 \mathrm{H})$, $1.52-1.45(\mathrm{~m}, 3 \mathrm{H}), 1.44-1.38(\mathrm{~m}, 1 \mathrm{H}), 1.25(\mathrm{br} \mathrm{d}, J=6.4 \mathrm{~Hz}, 5 \mathrm{H}), 1.2(\mathrm{br} \mathrm{s}, 2 \mathrm{H}), 1.18-1.08(\mathrm{~m}, 55 \mathrm{H}), 0.99(\mathrm{br} \mathrm{d}, J=6.8 \mathrm{~Hz}, 8 \mathrm{H})$, $0.94-0.9(\mathrm{~m}, 10 \mathrm{H}), 0.69(\mathrm{br} \mathrm{d}, J=6.8 \mathrm{~Hz}, 3 \mathrm{H}), 0.65-0.62(\mathrm{~m}, 2 \mathrm{H}), 0.58(\mathrm{br} \mathrm{d}, J$

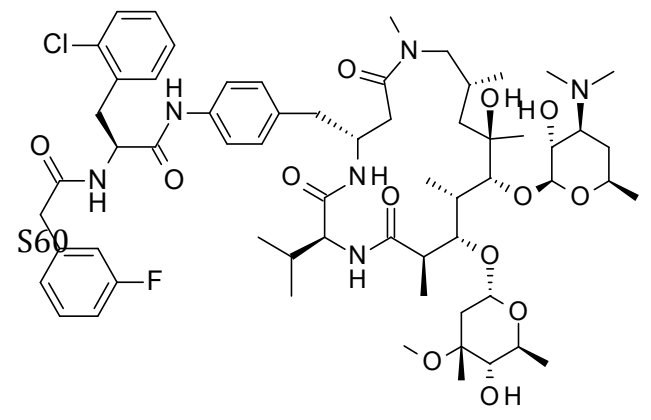
$=6.4 \mathrm{~Hz}, 5 \mathrm{H}), 0.5(\mathrm{br} \mathrm{d}, J=6.6 \mathrm{~Hz}, 5 \mathrm{H})$.

(2S)-3-(2-chlorophenyl)- $N$-[4-[[(2S,5R,10R,12R,13R,14S,15S,16R)-13-( $\beta$-Ddesosaminyl)oxy-12-hydroxy-15-( $\alpha$-L-cladinosyl)oxy-2-isopropyl- 
8,10,12,14,16-pentamethyl-3,7,17-trioxo-1,4,8-triazacycloheptadec-5-yl]methyl]phenyl]-2-[[2-(3-

fluorophenyl)acetyl]amino]propanamide (33)

Starting from 3-fluorophenylacetic acid $(10.17 \mathrm{mg}, 0.07 \mathrm{mmol}$ and E-1b $(70 \mathrm{mg}, 0.07 \mathrm{mmol})$ title product (24.87 mg, yield 30 $\%$, purity $94.68 \%$ ) was obtained by prep HPLC purification. $\mathrm{ES}^{+} \mathrm{m} / \mathrm{z} 1181.52[\mathrm{M}+\mathrm{H}]^{+}$. Two sets of signals in the NMR (most likely conformers). ${ }^{1} \mathrm{H}$ NMR $\left(600 \mathrm{MHz}, \mathrm{DMSO}-\mathrm{d}_{6}\right) \delta / \mathrm{ppm} 10(\mathrm{~s}, 1 \mathrm{H}), 9.97(\mathrm{~s}, 1 \mathrm{H}), 8.56-8.52(\mathrm{~m}, 3 \mathrm{H}), 8.1(\mathrm{br} \mathrm{d}, J=8.4 \mathrm{~Hz}, 2 \mathrm{H})$, $7.9(\mathrm{br} \mathrm{d}, J=9.7 \mathrm{~Hz}, 2 \mathrm{H}), 7.46(\mathrm{~d}, J=8.6 \mathrm{~Hz}, 2 \mathrm{H}), 7.42(\mathrm{~d}, J=8.6 \mathrm{~Hz}, 2 \mathrm{H}), 7.39(\mathrm{~d}, J=8.1 \mathrm{~Hz}, 2 \mathrm{H}), 7.31-7.26(\mathrm{~m}, 5 \mathrm{H}), 7.24-7.19$ (m, 2H), 7.19-7.14 (m, 3H), 7.14-7.1 (m, 3H), 7.05-6.97 (m, 5H), 4.82-4.76 (m, 3H), $4.63(\mathrm{br} \mathrm{d}, J=4.2 \mathrm{~Hz}, 2 \mathrm{H}), 4.45(\mathrm{~d}, J=7.3$ $\mathrm{Hz}, 2 \mathrm{H}), 4.37(\mathrm{~d}, J=7.2 \mathrm{~Hz}, 2 \mathrm{H}), 4.29(\mathrm{~d}, J=7.7 \mathrm{~Hz}, 2 \mathrm{H}), 4.23(\mathrm{~d}, J=8.3 \mathrm{~Hz}, 2 \mathrm{H}), 4.13(\mathrm{br} \mathrm{s}, 2 \mathrm{H}), 4.10-3.94(\mathrm{~m}, 5 \mathrm{H}), 4-3.94(\mathrm{~m}$, $1 \mathrm{H}), 3.89(\mathrm{~s}, 1 \mathrm{H}), 3.84(\mathrm{br} \mathrm{d}, J=8.1 \mathrm{~Hz}, 2 \mathrm{H}), 3.7(\mathrm{~s}, 1 \mathrm{H}), 3.67(\mathrm{br} \mathrm{dd}, J=11.4,6.2 \mathrm{~Hz}, 1 \mathrm{H}), 3.55-3.44(\mathrm{~m}, 6 \mathrm{H}), 3.34-3.34(\mathrm{~m}$, 25H), 3.25-3.15 (m, 7H), 3.12-2.96 (m, 5H), 2.94-2.85 (m, 3H), $2.8(\mathrm{~s}, 3 \mathrm{H}), 2.7$ (br dd, $J=13.5,6.5 \mathrm{~Hz}, 2 \mathrm{H}), 2.64-2.55(\mathrm{~m}, 4 \mathrm{H})$, $2.50-2.35(\mathrm{~m}, 4 \mathrm{H}), 2.28-2.18(\mathrm{~m}, 11 \mathrm{H}), 2.1(\mathrm{~s}, 2 \mathrm{H}), 2.03-1.91(\mathrm{~m}, 2 \mathrm{H}), 1.81-1.72(\mathrm{~m}, 1 \mathrm{H}), 1.61(\mathrm{br} \mathrm{d}, J=6.8 \mathrm{~Hz}, 2 \mathrm{H}), 1.54-1.39$ $(\mathrm{m}, 2 \mathrm{H}), 1.28-1.22(\mathrm{~m}, 2 \mathrm{H}), 1.21-1.07(\mathrm{~m}, 22 \mathrm{H}), 0.99(\mathrm{br} \mathrm{d}, J=7.3 \mathrm{~Hz}, 5 \mathrm{H}), 0.96-0.87(\mathrm{~m}, 5 \mathrm{H}), 0.69(\mathrm{~d}, J=6.8 \mathrm{~Hz}, 3 \mathrm{H}), 0.63(\mathrm{br}$ d, $J=6.8 \mathrm{~Hz}, 3 \mathrm{H}), 0.58(\mathrm{~d}, J=6.8 \mathrm{~Hz}, 3 \mathrm{H}), 0.51(\mathrm{~d}, J=6.8 \mathrm{~Hz}, 3 \mathrm{H})$.

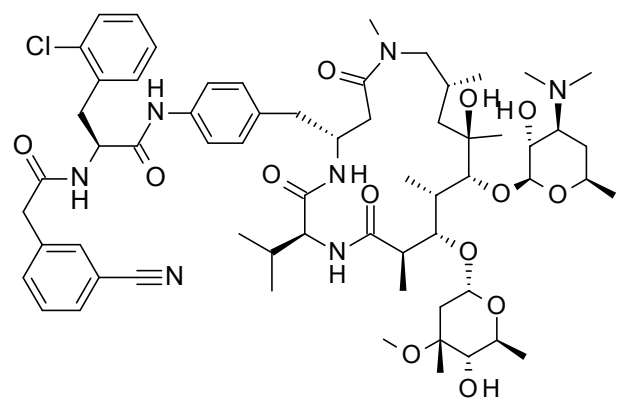

(2S)-3-(2-chlorophenyl)-2-[[2-(3-cyanophenyl)acetyl]amino]- $N$-[4$[[(2 S, 5 R, 10 R, 12 R, 13 R, 14 S, 15 S, 16 R)$-13-( $\beta$-D-desosaminyl)oxy-12-hydroxy15-( $\alpha$-L-cladinosyl)oxy-2-isopropyl-8,10,12,14,16-pentamethyl-3,7,17trioxo-1,4,8-triazacycloheptadec-5-yl]methyl]phenyl]propenamide (35) Starting from 3-cyanophenylacetic acid (11 $\mathrm{mg}, 0.68 \mathrm{mmol})$ and $\mathbf{E - 1 \mathbf { b }}(70 \mathrm{mg}$, $0.067 \mathrm{mmol}$ ) title product (50 $\mathrm{mg}$, yield $63 \%$, purity $98.83 \%$ ) was obtained by prep HPLC purification. ES $\mathrm{m} / \mathrm{z} 1188.35[\mathrm{M}+\mathrm{H}]^{+}$. Two sets of signals in the NMR (most likely conformers). ${ }^{1} \mathrm{H}$ NMR $\left(500 \mathrm{MHz}\right.$, DMSO-d $\left.\mathrm{d}_{6}\right) \delta / \mathrm{ppm} 10.01(\mathrm{~s}$, $1 \mathrm{H}), 9.97(\mathrm{~s}, 1 \mathrm{H}), 8.58(\mathrm{t}, J=7.4 \mathrm{~Hz}, 3 \mathrm{H}), 8.1(\mathrm{br} \mathrm{d}, J=8.9 \mathrm{~Hz}, 2 \mathrm{H}), 7.89(\mathrm{br} \mathrm{d}, J$ $=8.9 \mathrm{~Hz}, 2 \mathrm{H}), 7.71-7.64(\mathrm{~m}, 2 \mathrm{H}), 7.57(\mathrm{~s}, 2 \mathrm{H}), 7.50-7.45(\mathrm{~m}, 5 \mathrm{H}), 7.45-7.4(\mathrm{~m}$, $3 \mathrm{H}), 7.37(\mathrm{~d}, J=7.7 \mathrm{~Hz}, 2 \mathrm{H}), 7.26(\mathrm{t}, J=6.7 \mathrm{~Hz}, 3 \mathrm{H}), 7.23-7.18(\mathrm{~m}, 2 \mathrm{H}), 7.17-$ $7.14(\mathrm{~m}, 2 \mathrm{H}), 7.13-7.08(\mathrm{~m}, 4 \mathrm{H}), 4.81-4.75(\mathrm{~m}, 3 \mathrm{H}), 4.62(\mathrm{br} \mathrm{d}, J=4 \mathrm{~Hz}, 1 \mathrm{H})$, $4.44(\mathrm{br} \mathrm{d}, J=7 \mathrm{~Hz}, 2 \mathrm{H}), 4.36(\mathrm{br} \mathrm{d}, J=7.3 \mathrm{~Hz}, 2 \mathrm{H}), 4.28(\mathrm{~d}, J=7.6 \mathrm{~Hz}, 2 \mathrm{H}), 4.22(\mathrm{~d}, J=8.5 \mathrm{~Hz}, 2 \mathrm{H}), 4.16-4.09(\mathrm{~m}, 2 \mathrm{H}), 4.08-$ $3.99(\mathrm{~m}, 5 \mathrm{H}), 3.98-3.93(\mathrm{~m}, 1 \mathrm{H}), 3.88(\mathrm{~s}, 1 \mathrm{H}), 3.83(\mathrm{br} \mathrm{d}, J=7.3 \mathrm{~Hz}, 2 \mathrm{H}), 3.69(\mathrm{~s}, 1 \mathrm{H}), 3.68-3.63(\mathrm{~m}, 2 \mathrm{H}), 3.59-3.56(\mathrm{~m}, 1 \mathrm{H})$, $3.53(\mathrm{br} \mathrm{d}, J=13.4 \mathrm{~Hz}, 4 \mathrm{H}), 3.50-3.43(\mathrm{~m}, 3 \mathrm{H}), 3.2(\mathrm{~s}, 4 \mathrm{H}), 3.19-3.16(\mathrm{~m}, 2 \mathrm{H}), 3.15(\mathrm{~d}, J=5.5 \mathrm{~Hz}, 1 \mathrm{H}), 3.12-3.07(\mathrm{~m}, 1 \mathrm{H}), 3.06-3$ (m, 3H), 2.99-2.94 (m, 2H), 2.92-2.84 (m, 4H), $2.79(\mathrm{~s}, 4 \mathrm{H}), 2.77-2.71(\mathrm{~m}, 1 \mathrm{H}), 2.70-2.62(\mathrm{~m}, 2 \mathrm{H}), 2.60-2.55(\mathrm{~m}, 4 \mathrm{H}), 2.41-$ $2.33(\mathrm{~m}, 2 \mathrm{H}), 2.28-2.19(\mathrm{~m}, 12 \mathrm{H}), 2.12-2.05(\mathrm{~m}, 4 \mathrm{H}), 2.01-1.93(\mathrm{~m}, 2 \mathrm{H}), 1.79-1.71(\mathrm{~m}, 1 \mathrm{H}), 1.63-1.57(\mathrm{~m}, 2 \mathrm{H}), 1.56-1.38(\mathrm{~m}$, $4 \mathrm{H}), 1.35-1.21(\mathrm{~m}, 8 \mathrm{H}), 1.20-1.12(\mathrm{~m}, 19 \mathrm{H}), 1.11-1.06(\mathrm{~m}, 11 \mathrm{H}), 0.98(\mathrm{br} \mathrm{d}, J=7 \mathrm{~Hz}, 5 \mathrm{H}), 0.95-0.88(\mathrm{~m}, 6 \mathrm{H}), 0.87-0.79(\mathrm{~m}$, $1 \mathrm{H}), 0.68(\mathrm{~d}, J=6.7 \mathrm{~Hz}, 3 \mathrm{H}), 0.62(\mathrm{br} \mathrm{d}, J=6.4 \mathrm{~Hz}, 3 \mathrm{H}), 0.57(\mathrm{~d}, J=6.7 \mathrm{~Hz}, 3 \mathrm{H}), 0.5(\mathrm{~d}, J=6.7 \mathrm{~Hz}, 3 \mathrm{H})$.

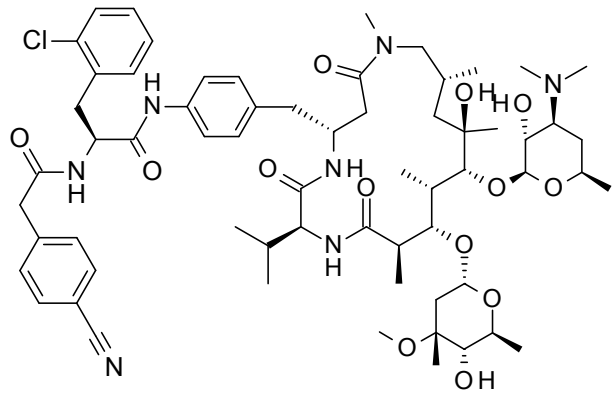

(2S)-3-(2-chlorophenyl)-2-[[2-(4-cyanophenyl)acetyl]amino]- $N$-[4$[[(2 S, 5 R, 10 R, 12 R, 13 R, 14 S, 15 S, 16 R)$-13-( $\beta$-D-desosaminyl)oxy-12-hydroxy15-( $\alpha$-L-cladinosyl)oxy-2-isopropyl-8,10,12,14,16-pentamethyl-3,7,17trioxo-1,4,8-triazacycloheptadec-5-yl]methyl]phenyl]propenamide (36) Starting from 4-cyanophenylac etic acid $(10.8 \mathrm{mg}, 0.067 \mathrm{mmol})$ and $\mathbf{E}-\mathbf{1 b}(70$ $\mathrm{mg}, 0.067 \mathrm{mmol}$ ) title product $(60 \mathrm{mg}$, yield $75 \%$, purity $99.26 \%$ ) was obtained by prep HPLC purification. $\mathrm{ES}^{+} \mathrm{m} / \mathrm{z}=1188.35[\mathrm{M}+\mathrm{H}]^{+}$. Two sets of signals in the NMR (most likely conformers). ${ }^{1} \mathrm{H}$ NMR (500 MHz, DMSO-d $\left.\mathrm{d}_{6}\right)$ $\delta / \mathrm{ppm} 10.02(\mathrm{~s}, 1 \mathrm{H}), 9.98(\mathrm{~s}, 1 \mathrm{H}), 8.65-8.56(\mathrm{~m}, 2 \mathrm{H}), 8.11(\mathrm{br} \mathrm{d}, J=8.9 \mathrm{~Hz}, 2 \mathrm{H})$, $7.9(\mathrm{br} \mathrm{d}, J=8.9 \mathrm{~Hz}, 2 \mathrm{H}), 7.72(\mathrm{~d}, J=8.5 \mathrm{~Hz}, 4 \mathrm{H}), 7.45(\mathrm{~d}, J=8.5 \mathrm{~Hz}, 3 \mathrm{H}), 7.42$ $(\mathrm{d}, J=8.5 \mathrm{~Hz}, 3 \mathrm{H}), 7.38(\mathrm{dd}, J=7.9,1.2 \mathrm{~Hz}, 3 \mathrm{H}), 7.34(\mathrm{~d}, J=8.2 \mathrm{~Hz}, 3 \mathrm{H}), 7.30-$ $7.26(\mathrm{~m}, 3 \mathrm{H}), 7.25-7.2(\mathrm{~m}, 2 \mathrm{H}), 7.20-7.15(\mathrm{~m}, 2 \mathrm{H}), 7.14-7.1(\mathrm{~m}, 3 \mathrm{H}), 4.82-4.77(\mathrm{~m}, 3 \mathrm{H}), 4.63$ (br d, $J=4 \mathrm{~Hz}, 1 \mathrm{H}), 4.45(\mathrm{~d}, J=7$ $\mathrm{Hz}, 1 \mathrm{H}), 4.37(\mathrm{~d}, J=7 \mathrm{~Hz}, 1 \mathrm{H}), 4.29(\mathrm{~d}, J=7.6 \mathrm{~Hz}, 2 \mathrm{H}), 4.23(\mathrm{~d}, J=8.2 \mathrm{~Hz}, 1 \mathrm{H}), 4.15-4.11(\mathrm{~m}, 2 \mathrm{H}), 4.10-4(\mathrm{~m}, 5 \mathrm{H}), 4-3.94(\mathrm{~m}$, $1 \mathrm{H}), 3.89(\mathrm{~s}, 1 \mathrm{H}), 3.84(\mathrm{br} \mathrm{d}, J=8.5 \mathrm{~Hz}, 2 \mathrm{H}), 3.7(\mathrm{~s}, 1 \mathrm{H}), 3.69-3.64(\mathrm{~m}, 1 \mathrm{H}), 3.61(\mathrm{~s}, 1 \mathrm{H}), 3.58(\mathrm{~d}, J=7.3 \mathrm{~Hz}, 3 \mathrm{H}), 3.55-3.5(\mathrm{~m}$, $2 \mathrm{H}), 3.46(\mathrm{br} \mathrm{d}, J=5.2 \mathrm{~Hz}, 1 \mathrm{H}), 3.21(\mathrm{~s}, 3 \mathrm{H}), 3.19(\mathrm{~s}, 4 \mathrm{H}), 3.18-3.13(\mathrm{~m}, 1 \mathrm{H}), 3.12-3.07(\mathrm{~m}, 1 \mathrm{H}), 3.06-3.02(\mathrm{~m}, 2 \mathrm{H}), 3.02-2.94$ (m, 2H), 2.93-2.85 (m, 3H), $2.8(\mathrm{~s}, 3 \mathrm{H}), 2.78-2.67(\mathrm{~m}, 2 \mathrm{H}), 2.65-2.54(\mathrm{~m}, 5 \mathrm{H}), 2.48-2.42(\mathrm{~m}, 2 \mathrm{H}), 2.40-2.33(\mathrm{~m}, 1 \mathrm{H}), 2.29-2.19$ (m, 12H), 2.12-2.05 (m, 1H), 2-1.94 (m, 2H), 1.81-1.72 (m, 2H), 1.66-1.57 (m, 2H), 1.53-1.41 (m, 2H), 1.40-1.33 (m, 1H), 1.31-1.26 (m, 1H), 1.26-1.22 (m, 6H), $1.19(\mathrm{br} \mathrm{d}, J=12.2 \mathrm{~Hz}, 6 \mathrm{H}), 1.17-1.12(\mathrm{~m}, 14 \mathrm{H}), 1.12-1.07(\mathrm{~m}, 12 \mathrm{H}), 0.99(\mathrm{br} \mathrm{d}, J=7 \mathrm{~Hz}$, $5 \mathrm{H}), 0.94-0.84(\mathrm{~m}, 6 \mathrm{H}), 0.68(\mathrm{~d}, J=6.7 \mathrm{~Hz}, 3 \mathrm{H}), 0.63(\mathrm{br} \mathrm{d}, J=6.4 \mathrm{~Hz}, 3 \mathrm{H}), 0.58(\mathrm{~d}, J=6.4 \mathrm{~Hz}, 3 \mathrm{H}), 0.51(\mathrm{~d}, J=6.7 \mathrm{~Hz}, 3 \mathrm{H})$.

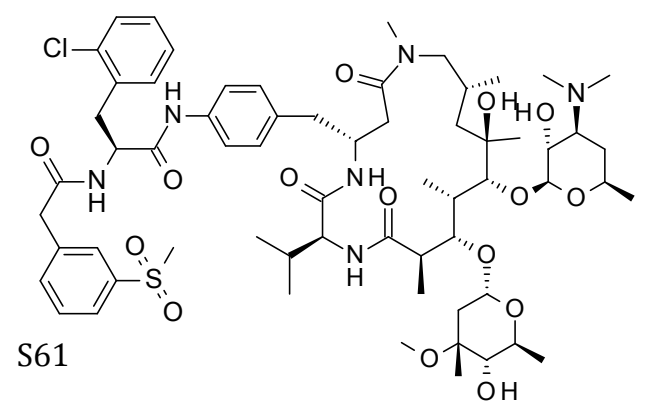

(2S)-3-(2-chlorophenyl)- $N$-[4-[[(2S,5R,10R,12R,13R,14S,15S,16R)-13-( $\beta$-Ddesosaminyl)oxy-12-hydroxy-15-( $\alpha$-L-cladinosyl)oxy-2-isopropyl8,10,12,14,16-pentamethyl-3,7,17-trioxo-1,4,8-triazacycloheptadec-5yl]methyl]phenyl]-2-[[2-(4methylsulfonylphenyl)acetyl]amino]propenamide (37) Starting from 3-(methylsulfonly)phenylacetic acid $(15 \mathrm{mg}, 0.7 \mathrm{mmol}$ ) and E1b $(70 \mathrm{mg}, 0.067 \mathrm{mmol}$ ) title product ( $50 \mathrm{mg}$, yield $60 \%$, purity $98.8 \%$ ) was obtained by prep HPLC purification. $\mathrm{ES}^{+} \mathrm{m} / \mathrm{z} 1241.34[\mathrm{M}+\mathrm{H}]^{+}$. Two sets of 
signals in the NMR (most likely conformers). ${ }^{1} \mathrm{H}$ NMR $\left(500 \mathrm{MHz}, \mathrm{DMSO}-\mathrm{d}_{6}\right) \delta / \mathrm{ppm} 10.01(\mathrm{~s}, 1 \mathrm{H}), 9.97(\mathrm{~s}, 1 \mathrm{H}), 8.64-8.59(\mathrm{~m}$, $2 \mathrm{H}), 8.11(\mathrm{br} \mathrm{d}, J=8.5 \mathrm{~Hz}, 2 \mathrm{H}), 7.9(\mathrm{br} \mathrm{d}, J=8.5 \mathrm{~Hz}, 2 \mathrm{H}), 7.81(\mathrm{~s}, 2 \mathrm{H}), 7.78(\mathrm{~d}, J=7.9 \mathrm{~Hz}, 2 \mathrm{H}), 7.56-7.52(\mathrm{~m}, 2 \mathrm{H}), 7.5(\mathrm{~s}, 1 \mathrm{H})$, $7.48(\mathrm{~s}, 1 \mathrm{H}), 7.45(\mathrm{~d}, J=8.2 \mathrm{~Hz}, 2 \mathrm{H}), 7.42(\mathrm{~d}, J=8.5 \mathrm{~Hz}, 2 \mathrm{H}), 7.37(\mathrm{dd}, J=7.9,1.2 \mathrm{~Hz}, 2 \mathrm{H}), 7.29-7.25(\mathrm{~m}, 3 \mathrm{H}), 7.21(\mathrm{td}, J=7.6$, $1.5 \mathrm{~Hz}, 2 \mathrm{H}), 7.18-7.14(\mathrm{~m}, 2 \mathrm{H}), 7.14-7.09(\mathrm{~m}, 4 \mathrm{H}), 4.80-4.76(\mathrm{~m}, 3 \mathrm{H}), 4.63(\mathrm{br} \mathrm{d}, J=4.3 \mathrm{~Hz}, 1 \mathrm{H}), 4.45(\mathrm{~d}, J=7.3 \mathrm{~Hz}, 1 \mathrm{H}), 4.37$ (br d, $J=7 \mathrm{~Hz}, 1 \mathrm{H}), 4.29(\mathrm{~d}, J=7.6 \mathrm{~Hz}, 2 \mathrm{H}), 4.23(\mathrm{~d}, J=8.5 \mathrm{~Hz}, 1 \mathrm{H}), 4.16-4.09(\mathrm{~m}, 2 \mathrm{H}), 4.08-4(\mathrm{~m}, 5 \mathrm{H}), 3.99-3.94(\mathrm{~m}, 1 \mathrm{H}), 3.91-$ $3.88(\mathrm{~m}, 1 \mathrm{H}), 3.84(\mathrm{br} \mathrm{d}, J=8.5 \mathrm{~Hz}, 2 \mathrm{H}), 3.7(\mathrm{~s}, 1 \mathrm{H}), 3.69-3.63(\mathrm{~m}, 1 \mathrm{H}), 3.61(\mathrm{~s}, 3 \mathrm{H}), 3.58(\mathrm{br} \mathrm{s}, 1 \mathrm{H}), 3.52(\mathrm{br} \mathrm{d}, J=6.7 \mathrm{~Hz}, 3 \mathrm{H})$, $3.46(\mathrm{br} \mathrm{d}, J=5.2 \mathrm{~Hz}, 3 \mathrm{H}), 3.42-3.37(\mathrm{~m}, 2 \mathrm{H}), 3.23-3.2(\mathrm{~m}, 3 \mathrm{H}), 3.19-3.17(\mathrm{~m}, 7 \mathrm{H}), 3.17-3.14(\mathrm{~m}, 1 \mathrm{H}), 3.12-3.08(\mathrm{~m}, 1 \mathrm{H}), 3.07-$ $3.01(\mathrm{~m}, 3 \mathrm{H}), 3-2.94(\mathrm{~m}, 2 \mathrm{H}), 2.94-2.85(\mathrm{~m}, 3 \mathrm{H}), 2.8(\mathrm{~s}, 3 \mathrm{H}), 2.71-2.66(\mathrm{~m}, 2 \mathrm{H}), 2.63-2.55(\mathrm{~m}, 5 \mathrm{H}), 2.43-2.33(\mathrm{~m}, 3 \mathrm{H}), 2.29-$ $2.2(\mathrm{~m}, 12 \mathrm{H}), 2.13-2.07(\mathrm{~m}, 1 \mathrm{H}), 2-1.95(\mathrm{~m}, 2 \mathrm{H}), 1.81-1.72(\mathrm{~m}, 2 \mathrm{H}), 1.68-1.58(\mathrm{~m}, 2 \mathrm{H}), 1.57-1.53(\mathrm{~m}, 2 \mathrm{H}), 1.51-1.45(\mathrm{~m}, 2 \mathrm{H})$, 1.44-1.38 (m, 1H), 1.35-1.28 (m, 3H), 1.24 (br s, 3H), 1.21-1.15 (m, 12H), 1.15-1.07 (m, 18H), 0.99 (br d, J= 7.3 Hz, 5H), 0.94$0.9(\mathrm{~m}, 5 \mathrm{H}), 0.69(\mathrm{~d}, J=6.7 \mathrm{~Hz}, 3 \mathrm{H}), 0.63(\mathrm{br} \mathrm{d}, J=6.7 \mathrm{~Hz}, 3 \mathrm{H}), 0.58(\mathrm{~d}, J=6.7 \mathrm{~Hz}, 3 \mathrm{H}), 0.51(\mathrm{~d}, J=6.7 \mathrm{~Hz}, 3 \mathrm{H})$.

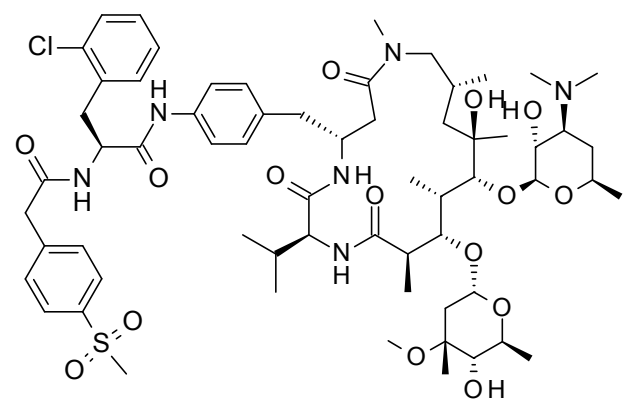

(2S)-3-(2-chlorophenyl)- $N$-[4-[[(2S,5R,10R,12R,13R,14S,15S,16R)-13-( $\beta$-Ddesosaminyl)oxy-12-hydroxy-15-( $\alpha$-L-cladinosyl)oxy-2-isopropyl8,10,12,14,16-pentamethyl-3,7,17-trioxo-1,4,8-triazacycloheptadec-5yl]methyl]phenyl]-2-[[2-(3-

methylsulfonylphenyl)acetyl]amino]propenamide (38)

Starting from 4-(methylsulfonyl)phenylacetic acid (14.3 $\mathrm{mg}, 0.067 \mathrm{mmol})$ and E-1b (70 $\mathrm{mg}, 0.067 \mathrm{mmol}$ ) title product ( $50 \mathrm{mg}$, yield $60 \%$, purity 98.88 $\%$ ) was obtained by prep HPLC purification. $\mathrm{ES}^{+} \mathrm{m} / \mathrm{z} 1241.33[\mathrm{M}+\mathrm{H}]^{+}$. Two sets of signals in the NMR (most likely conformers). ${ }^{1} \mathrm{H}$ NMR (500 MHz, DMSO$\left.\mathrm{d}_{6}\right) \delta / \mathrm{ppm} 10.01(\mathrm{~s}, 1 \mathrm{H}), 9.99(\mathrm{~s}, 1 \mathrm{H}), 8.66-8.6(\mathrm{~m}, 2 \mathrm{H}), 8.11(\mathrm{br} \mathrm{d}, J=8.5 \mathrm{~Hz}$, $2 \mathrm{H}), 7.9(\mathrm{br} \mathrm{d}, J=8.9 \mathrm{~Hz}, 2 \mathrm{H}), 7.81(\mathrm{~d}, J=8.2 \mathrm{~Hz}, 4 \mathrm{H}), 7.48-7.36(\mathrm{~m}, 12 \mathrm{H}), 7.30-$ $7.26(\mathrm{~m}, 3 \mathrm{H}), 7.24-7.1(\mathrm{~m}, 7 \mathrm{H}), 4.83-4.76(\mathrm{~m}, 3 \mathrm{H}), 4.63(\mathrm{br} \mathrm{d}, J=4.3 \mathrm{~Hz}, 1 \mathrm{H}), 4.45(\mathrm{~d}, J=7 \mathrm{~Hz}, 1 \mathrm{H}), 4.37$ (br d, $J=7.3 \mathrm{~Hz}, 1 \mathrm{H})$, $4.29(\mathrm{~d}, J=7.6 \mathrm{~Hz}, 2 \mathrm{H}), 4.23$ (d, $J=8.2 \mathrm{~Hz}, 1 \mathrm{H}), 4.17-4.11(\mathrm{~m}, 2 \mathrm{H}), 4.08-3.99(\mathrm{~m}, 5 \mathrm{H}), 3.97$ (br t, $J=7.5 \mathrm{~Hz}, 1 \mathrm{H}), 3.89(\mathrm{~s}, 1 \mathrm{H})$, $3.84(\mathrm{br} \mathrm{d}, J=7.6 \mathrm{~Hz}, 2 \mathrm{H}), 3.7(\mathrm{~s}, 1 \mathrm{H}), 3.69-3.64(\mathrm{~m}, 1 \mathrm{H}), 3.63(\mathrm{~s}, 1 \mathrm{H}), 3.6(\mathrm{~d}, J=7 \mathrm{~Hz}, 3 \mathrm{H}), 3.56(\mathrm{~s}, 1 \mathrm{H}), 3.52(\mathrm{br} \mathrm{d}, J=6.7 \mathrm{~Hz}$, $2 \mathrm{H}), 3.46(\mathrm{br} \mathrm{d}, J=5.2 \mathrm{~Hz}, 1 \mathrm{H}), 3.21(\mathrm{~s}, 4 \mathrm{H}), 3.19(\mathrm{~s}, 7 \mathrm{H}), 3.16(\mathrm{~d}, J=5.8 \mathrm{~Hz}, 1 \mathrm{H}), 3.11-2.96(\mathrm{~m}, 7 \mathrm{H}), 2.93-2.85(\mathrm{~m}, 3 \mathrm{H}), 2.8(\mathrm{~s}$, $3 \mathrm{H}), 2.65-2.61(\mathrm{~m}, 1 \mathrm{H}), 2.61-2.55(\mathrm{~m}, 3 \mathrm{H}), 2.40-2.34(\mathrm{~m}, 1 \mathrm{H}), 2.29-2.26(\mathrm{~m}, 1 \mathrm{H}), 2.23(\mathrm{~s}, 12 \mathrm{H}), 2.01-1.94(\mathrm{~m}, 2 \mathrm{H}), 1.81-1.73$ (m, 2H), 1.64-1.58 (m, 2H), 1.52-1.45 (m, 1H), 1.45-1.38 (m,1H), 1.36-1.3 (m, 1H), 1.28-1.22 (m, 6H), $1.19(\mathrm{br} \mathrm{d}, J=13.1 \mathrm{~Hz}$, $6 \mathrm{H}), 1.17-1.12(\mathrm{~m}, 14 \mathrm{H}), 1.12-1.07(\mathrm{~m}, 12 \mathrm{H}), 0.99(\mathrm{br} \mathrm{d}, J=7.3 \mathrm{~Hz}, 5 \mathrm{H}), 0.93(\mathrm{br} \mathrm{d}, J=6.7 \mathrm{~Hz}, 2 \mathrm{H}), 0.91(\mathrm{br} \mathrm{d}, J=6.4 \mathrm{~Hz}, 3 \mathrm{H})$, $0.88-0.83(\mathrm{~m}, 2 \mathrm{H}), 0.69(\mathrm{~d}, J=6.7 \mathrm{~Hz}, 3 \mathrm{H}), 0.63(\mathrm{br} \mathrm{d}, J=6.7 \mathrm{~Hz}, 3 \mathrm{H}), 0.58(\mathrm{~d}, J=6.7 \mathrm{~Hz}, 3 \mathrm{H}), 0.51(\mathrm{~d}, J=6.7 \mathrm{~Hz}, 3 \mathrm{H})$.

\section{Preparation of compound 39}

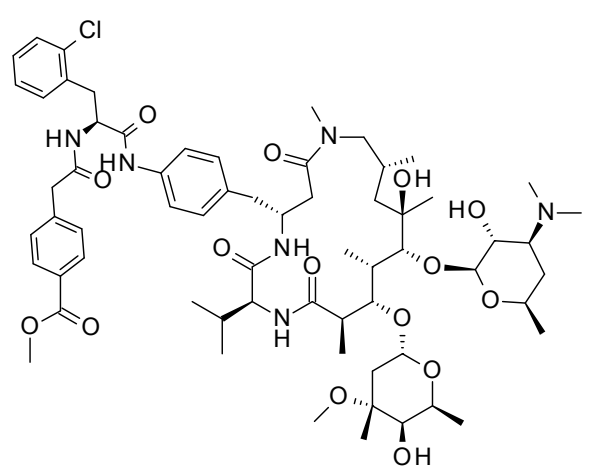

$(2 S, 5 R, 10 R, 12 R, 13 R, 14 S, 15 S, 16 R)-5-[[4-[[(2 S)-2-[[2-(4-$

methoxycarbonylphenyl)acetyl]amino]-3-(2-

chlorophenyl)propanoyl]amino]phenyl]methyl]-15-O-( $\alpha$-L-cladinosyl)-13-

$O$-( $\beta$-D-desasaminyl)-12,13,15-trihydroxy-2-isopropyl-8,10,12,14,16-

pentamethyl-1,4,8-triazacycloheptadecane-3,7,17-trione (39a)

To a solution of (p-methoxycarbony)phenylacetic acid (21 $\mathrm{mg}, 0.11 \mathrm{mmol})$, HOAT ( $7 \mathrm{mg}, 0.05 \mathrm{mmol}$ ) and HATU (42 $\mathrm{mg}, 0.11 \mathrm{mmol})$ in DCM $(1 \mathrm{~mL})$ TMP $(28 \mu \mathrm{L}, 0.175 \mathrm{mmol})$ was added and reaction mixture was stirred at room temperature for $30 \mathrm{~min}$. A solution of E-1b $(105 \mathrm{mg}, 0.1 \mathrm{mmol})$ in DCM (1 mL) was added and reaction mixture was stirred at room temperature for $1 \mathrm{~h}$. Reaction mixture was diluted with DCM $(5 \mathrm{~mL})$ and reaction was quenched with sat. $\mathrm{NaHCO}_{3}(5 \mathrm{~mL})$. Layers were separated and aqueous one was extracted with DCM $(5 \mathrm{~mL})$. Combined organics were washed with water (5 $\mathrm{mL}$ ), dried over $\mathrm{Na}_{2} \mathrm{SO}_{4}$ and evaporated to dryness. Sample was purified by flash chromatography with DCM:MeOH: $\mathrm{NH}_{4} \mathrm{OH}=$ 90:9:1.5 as eluent to yield the title compound as white solid (88 mg). ES ${ }^{+} \mathrm{m} / \mathrm{z} 1221.3[\mathrm{M}+\mathrm{H}]^{+}$.

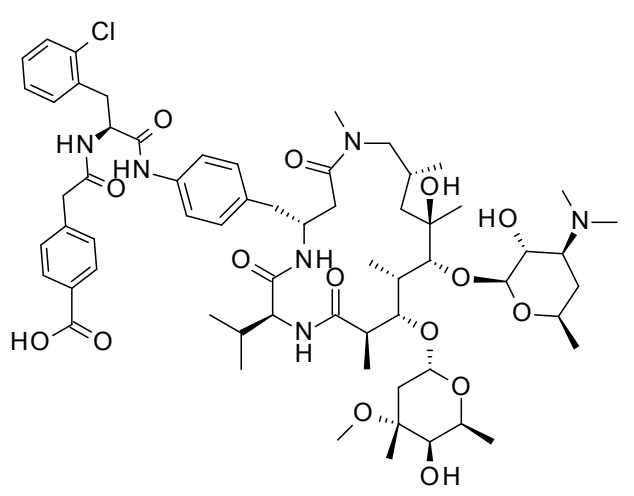

$(2 S, 5 R, 10 R, 12 R, 13 R, 14 S, 15 S, 16 R)-5-[[4-[[(2 S)-2-[[2-(4-$ carboxyphenyl)acetyl]amino]-3-(2-chlorophenyl)propanoyl]amino]phenyl] methyl]-15-O-( $\alpha$-L-cladinosyl)-13-O-( $\beta$-D-desasaminyl)-12,13,15trihydroxy-2-isopropyl-8,10,12,14,16-pentamethyl-1,4,8-triazacyclo heptadecane-3,7,17-trione (39)

To a solution of 39a (70 mg, $0.05 \mathrm{mmol}$ ) in THF ( $3 \mathrm{~mL}$ ) solution of LiOH.H2O $(11 \mathrm{mg}, 0.27 \mathrm{mmol})$ in water $(0.3 \mathrm{~mL})$ was added. Reaction mixture was stirred at room temperature for $24 \mathrm{~h}$. Reaction mixture was diluted with water $(5 \mathrm{~mL})$ and neutralised with sat. $\mathrm{KH}_{2} \mathrm{PO}_{4}$. A white precipitate was formed that was filtered, washed with water and dried to yield title compound ( $35 \mathrm{mg}$, yield $53 \%$, purity $96.6 \%$ ). ES ${ }^{+} \mathrm{m} / \mathrm{z} 1207.49[\mathrm{M}+\mathrm{H}]^{+}$. Two sets of signals in the NMR (most likely conformers). ${ }^{1} \mathrm{H}$ NMR (500 MHz, DMSO- $\mathrm{d}_{6}$ ) $\delta / p p m 10.02$ (s, 1H), 9.99 (s, 1H), 8.64-8.54 (m, 2H), $8.11(\mathrm{br} \mathrm{d}, J=8.9 \mathrm{~Hz}$, 
1H), 7.93-7.87 (m, 1H), 7.81 (d, J= 7.9 Hz, 3H), 7.47-7.37 (m, 5H), 7.31-7.26 (m, 3H), 7.26-7.15 (m, 8H), 7.14-7.09 (m, 3H), 4.84-4.74 (m, 3H), $4.64(\mathrm{br} \mathrm{s}, 1 \mathrm{H}), 4.45(\mathrm{br} \mathrm{d}, J=7.3 \mathrm{~Hz}, 2 \mathrm{H}), 4.38(\mathrm{br} \mathrm{d}, J=6.7 \mathrm{~Hz}, 1 \mathrm{H}), 4.3(\mathrm{br} \mathrm{d}, J=7.3 \mathrm{~Hz}, 2 \mathrm{H}), 4.23(\mathrm{br} \mathrm{d}, J=$ $7.6 \mathrm{~Hz}, 2 \mathrm{H}), 4.13$ (br s, 2H), 4.10-3.95 (m, 5H), 3.91 (br s, 1H), 3.83 (br d, $J=7.9 \mathrm{~Hz}, 2 \mathrm{H}), 3.76-3.64(\mathrm{~m}, 5 \mathrm{H}), 3.62-3.49(\mathrm{~m}$, $13 \mathrm{H}), 3.24-2.84(\mathrm{~m}, 24 \mathrm{H}), 2.8(\mathrm{~s}, 4 \mathrm{H}), 2.74-2.65(\mathrm{~m}, 2 \mathrm{H}), 2.64-2.54(\mathrm{~m}, 5 \mathrm{H}), 2.42-2.33(\mathrm{~m}, 2 \mathrm{H}), 2.26(\mathrm{~s}, 11 \mathrm{H}), 2.15-2.02(\mathrm{~m}$, $2 \mathrm{H}), 2.02-1.94(\mathrm{~m}, 2 \mathrm{H}), 1.82-1.73(\mathrm{~m}, 1 \mathrm{H}), 1.68-1.59(\mathrm{~m}, 2 \mathrm{H}), 1.52-1.44(\mathrm{~m}, 2 \mathrm{H}), 1.45-1.35(\mathrm{~m}, 1 \mathrm{H}), 1.24(\mathrm{br} \mathrm{s}, 4 \mathrm{H}), 1.22-1.06$ (m, 30H), $0.99(\mathrm{br} \mathrm{d}, J=7 \mathrm{~Hz}, 5 \mathrm{H}), 0.96-0.87(\mathrm{~m}, 5 \mathrm{H}), 0.69(\mathrm{br} \mathrm{d}, J=6.4 \mathrm{~Hz}, 2 \mathrm{H}), 0.63(\mathrm{br} \mathrm{d}, J=6.4 \mathrm{~Hz}, 2 \mathrm{H}), 0.58(\mathrm{br} \mathrm{d}, J=6.7$ $\mathrm{Hz}, 3 \mathrm{H}), 0.51$ (br d, $J=6.7 \mathrm{~Hz}, 3 \mathrm{H})$.

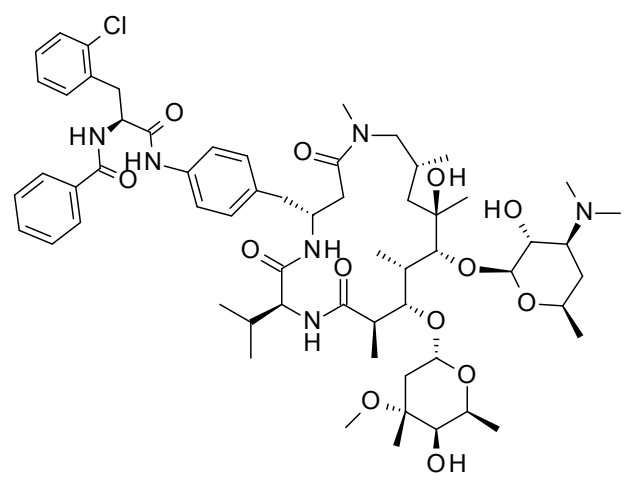

$N-[(1 S)-1-[(2-c h l o r o p h e n y l) m e t h y l]-2-[4-$

[[(2S,5R,10R,12R,13R,14S,15S,16R)-13-( $\beta$-D-desosaminyl)oxy-12-hydroxy15 -[(2R,4R,5S,6S)-5-hydroxy-4-methoxy-4,6-dimethyltetrahydropyran-2yl] oxy-2-isopropyl-8,10,12,14,16-pentamethyl-3,7,17-trioxo-1,4,8triazacycloheptadec-5-yl]methyl]anilino]-2-oxo-ethyl]benzamide (41) Starting from benzoic acid $(8.2 \mathrm{mg}, 0.067 \mathrm{mmol})$ and E-1b $(70 \mathrm{mg}, 0.067$ mmol) title product $(67.1 \mathrm{mg}, 87.1 \%$, purity $95.8 \%$ ) was obtained. Purification was performed by flash column chromatography. $\mathrm{ES}^{+} \mathrm{m} / \mathrm{z}$ $1149.62[\mathrm{M}+\mathrm{H}]^{+}$. Two sets of signals in the NMR (most likely conformers). ${ }^{1} \mathrm{H}$ NMR (500 MHz, DMSO-d $\left.\mathrm{d}_{6}\right) \delta / \mathrm{ppm} 10.01(\mathrm{~s}, 1 \mathrm{H}), 9.97(\mathrm{~s}, 1 \mathrm{H}), 8.76-8.72(\mathrm{~m}$, $3 \mathrm{H}$ ), 8.11 (br d, $J=8.9 \mathrm{~Hz}, 1 \mathrm{H}), 7.9(\mathrm{br} \mathrm{d}, J=8.9 \mathrm{~Hz}, 1 \mathrm{H}), 7.87-7.83(\mathrm{~m}, 4 \mathrm{H})$, 7.56-7.51 (m, 2H), 7.51-7.44 (m, 8H), $7.42(\mathrm{td}, J=4.7,2 \mathrm{~Hz}, 3 \mathrm{H}), 7.29$ (br d, $J$ $=8.5 \mathrm{~Hz}, 1 \mathrm{H}), 7.25-7.2(\mathrm{~m}, 4 \mathrm{H}), 7.15-7.1(\mathrm{~m}, 4 \mathrm{H}), 4.96(\mathrm{td}, J=8.5,5.8 \mathrm{~Hz}, 2 \mathrm{H})$, $4.79(\mathrm{br} \mathrm{d}, J=4.6 \mathrm{~Hz}, 2 \mathrm{H}), 4.63(\mathrm{br} \mathrm{d}, J=4 \mathrm{~Hz}, 1 \mathrm{H}), 4.45(\mathrm{~d}, J=7.3 \mathrm{~Hz}, 2 \mathrm{H}), 4.37(\mathrm{~d}, J=7.3 \mathrm{~Hz}, 2 \mathrm{H}), 4.29(\mathrm{~d}, J=7.9 \mathrm{~Hz}, 1 \mathrm{H}), 4.23$ (d, $J=8.5 \mathrm{~Hz}, 1 \mathrm{H}), 4.16-4.08(\mathrm{~m}, 2 \mathrm{H}), 4.08-4(\mathrm{~m}, 4 \mathrm{H}), 4-3.94(\mathrm{~m}, 1 \mathrm{H}), 3.89(\mathrm{~s}, 1 \mathrm{H}), 3.84(\mathrm{br} \mathrm{d}, J=7.6 \mathrm{~Hz}, 1 \mathrm{H}), 3.7(\mathrm{~s}, 1 \mathrm{H}), 3.67$ (br dd, $J=11.1,6.3 \mathrm{~Hz}, 1 \mathrm{H}), 3.62-3.56(\mathrm{~m}, 1 \mathrm{H}), 3.52(\mathrm{br} \mathrm{d}, J=7 \mathrm{~Hz}, 2 \mathrm{H}), 3.46(\mathrm{br} \mathrm{d}, J=5.5 \mathrm{~Hz}, 1 \mathrm{H}), 3.33-3.22(\mathrm{~m}, 5 \mathrm{H}), 3.21(\mathrm{~s}$, $4 \mathrm{H}), 3.19(\mathrm{~s}, 2 \mathrm{H}), 3.14-3.05(\mathrm{~m}, 3 \mathrm{H}), 3.05-2.94(\mathrm{~m}, 2 \mathrm{H}), 2.93-2.85(\mathrm{~m}, 4 \mathrm{H}), 2.8(\mathrm{~s}, 4 \mathrm{H}), 2.73-2.66(\mathrm{~m}, 1 \mathrm{H}), 2.64-2.55(\mathrm{~m}, 4 \mathrm{H})$, 2.49-2.35 (m, 4H), 2.28-2.17 (m, 14H), 2.09 (s, 2H), 2.03-1.93 (m, 3H), 1.81-1.74 (m, 1H), $1.6(\mathrm{br} \mathrm{d}, J=7.3 \mathrm{~Hz}, 2 \mathrm{H}), 1.51-1.38$ (m, 3H), $1.24(\mathrm{br} \mathrm{s}, 3 \mathrm{H}), 1.22-1.05(\mathrm{~m}, 33 \mathrm{H}), 0.99(\mathrm{br} \mathrm{d}, J=7.3 \mathrm{~Hz}, 6 \mathrm{H}), 0.95-0.89(\mathrm{~m}, 6 \mathrm{H}), 0.7(\mathrm{~d}, J=6.7 \mathrm{~Hz}, 2 \mathrm{H}), 0.64(\mathrm{br} \mathrm{d}, J$ $=6.7 \mathrm{~Hz}, 2 \mathrm{H}), 0.59(\mathrm{~d}, J=6.7 \mathrm{~Hz}, 4 \mathrm{H}), 0.52(\mathrm{~d}, J=6.7 \mathrm{~Hz}, 4 \mathrm{H})$.

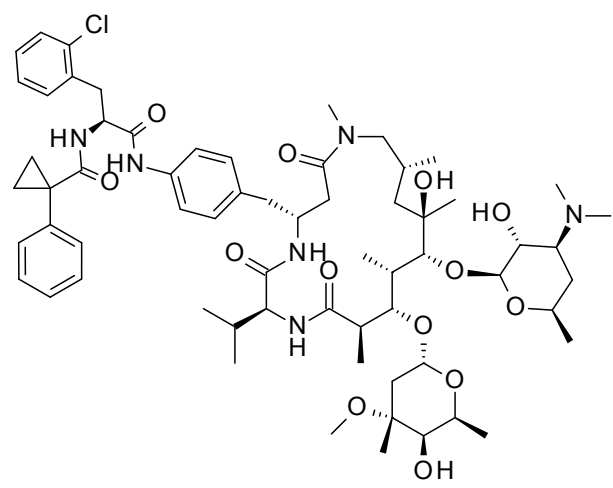

$N-[(1 S)-1-[(2-c h l o r o p h e n y l) m e t h y l]-2-[4-$

$[[(2 S, 5 R, 10 R, 12 R, 13 R, 14 S, 15 S, 16 R)-13-(\beta-D-d e s o s a m i n y l)$ oxy-12-hydroxy15-( $\alpha$-L-cladinosyl)oxy-2-isopropyl-8,10,12,14,16-pentamethyl-3,7,17trioxo-1,4,8-triazacycloheptadec-5-yl]methyl]anilino]-2-oxo-ethyl]-1-(4methoxyphenyl)cyclopropanecarboxamide (42)

Starting from 1-(4-methoxyphenyl)cyclopropanecarboxylic acid $(13 \mathrm{mg}$, $0.067 \mathrm{mmol}$ ) and E-1b (70 mg, $0.067 \mathrm{mmol}$ ) title product (54 mg, yield $66 \%$, purity $96.7 \%$ ) was obtained by prep HPLC purification. $\mathrm{ES}^{+} \mathrm{m} / \mathrm{z} 1219.59$ $[\mathrm{M}+\mathrm{H}]^{+} .{ }^{1} \mathrm{H}$ NMR $\left(500 \mathrm{MHz}\right.$, DMSO-d $\left.{ }_{6}\right) \delta 10.04(\mathrm{~s}, 1 \mathrm{H}), 10.01(\mathrm{~s}, 1 \mathrm{H}), 8.11(\mathrm{br}$ d, $J=8.9 \mathrm{~Hz}, 2 \mathrm{H}), 7.91(\mathrm{br} \mathrm{d}, J=8.5 \mathrm{~Hz}, 2 \mathrm{H}), 7.41-7.35(\mathrm{~m}, 6 \mathrm{H}), 7.30-7.19(\mathrm{~m}$, 9H), 7.16-7.09 (m, 5H), 6.91 (d, $J=8.9 \mathrm{~Hz}, 3 \mathrm{H}), 6.3$ (d, $J=7.9 \mathrm{~Hz}, 3 \mathrm{H}), 4.81-$ $4.73(\mathrm{~m}, 3 \mathrm{H}), 4.63(\mathrm{br} \mathrm{d}, J=4.9 \mathrm{~Hz}, 2 \mathrm{H}), 4.45(\mathrm{~d}, J=7.3 \mathrm{~Hz}, 1 \mathrm{H}), 4.37(\mathrm{br} \mathrm{d}, J=$ $7.3 \mathrm{~Hz}, 2 \mathrm{H}), 4.29$ (d, $J=7.6 \mathrm{~Hz}, 2 \mathrm{H}), 4.23(\mathrm{~d}, J=8.5 \mathrm{~Hz}, 2 \mathrm{H}), 4.13$ (br s, $2 \mathrm{H}$ ), 4.08-4.03 (m, 4H), 4.03-4 (m, 1H), 3.99-3.94 (m, 1H), 3.92-3.87 (m, 1H), $3.83(\mathrm{br} \mathrm{d}, J=7.3 \mathrm{~Hz}, 2 \mathrm{H}), 3.78(\mathrm{~s}, 5 \mathrm{H}), 3.7(\mathrm{~s}, 1 \mathrm{H})$, 3.69-3.63 (m, 2H), 3.62-3.55 (m, 1H), $3.52(\mathrm{br} \mathrm{d}, J=7 \mathrm{~Hz}, 2 \mathrm{H}), 3.48-3.43(\mathrm{~m}, 1 \mathrm{H}), 3.23-3.2(\mathrm{~m}, 4 \mathrm{H}), 3.19(\mathrm{~s}, 2 \mathrm{H}), 3.13-3.07$ $(\mathrm{m}, 3 \mathrm{H}), 3.06-3.01(\mathrm{~m}, 3 \mathrm{H}), 3.01-2.94(\mathrm{~m}, 2 \mathrm{H}), 2.94-2.85(\mathrm{~m}, 4 \mathrm{H}), 2.8(\mathrm{~s}, 4 \mathrm{H}), 2.77-2.73(\mathrm{~m}, 1 \mathrm{H}), 2.72-2.64(\mathrm{~m}, 2 \mathrm{H}), 2.63-2.55$ (m, 5H), 2.49-2.42 (m, 2H), 2.42-2.33 (m, 2H), 2.29-2.19 (m, 13H), 2.11-2.06 (m, 4H), 2-1.94 (m, 2H), 1.76 (dq, J = 13.8, 6.9 $\mathrm{Hz}, 1 \mathrm{H}), 1.61(\mathrm{br} \mathrm{d}, J=7.3 \mathrm{~Hz}, 2 \mathrm{H}), 1.51-1.38(\mathrm{~m}, 3 \mathrm{H}), 1.32-1.26(\mathrm{~m}, 3 \mathrm{H}), 1.26-1.18(\mathrm{~m}, 7 \mathrm{H}), 1.18-1.15(\mathrm{~m}, 9 \mathrm{H}), 1.15-1.11(\mathrm{~m}$, $13 \mathrm{H}), 1.10-1.07(\mathrm{~m}, 6 \mathrm{H}), 0.99(\mathrm{br} \mathrm{d}, J=7.3 \mathrm{~Hz}, 6 \mathrm{H}), 0.94-0.89(\mathrm{~m}, 8 \mathrm{H}), 0.68(\mathrm{~d}, J=6.4 \mathrm{~Hz}, 3 \mathrm{H}), 0.63(\mathrm{br} \mathrm{d}, J=6.7 \mathrm{~Hz}, 3 \mathrm{H}), 0.58$ $(\mathrm{d}, J=6.7 \mathrm{~Hz}, 3 \mathrm{H}), 0.5(\mathrm{~d}, J=6.7 \mathrm{~Hz}, 3 \mathrm{H})$.

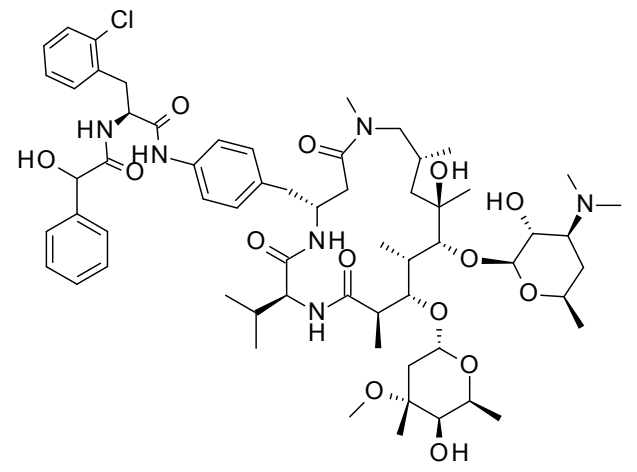

(2S)-3-(2-chlorophenyl)- $N$-[4-[[(2S,5R,10R,12R,13R,14S,15S,16R)-13-( $\beta$-Ddesosaminyl)oxy-12-hydroxy-15-( $\alpha$-L-cladinosyl)oxy-2-isopropyl8,10,12,14,16-pentamethyl-3,7,17-trioxo-1,4,8-triazacycloheptadec-5yl]methyl]phenyl]-2-[(2-hydroxy-2-phenyl-acetyl)amino]propenamide (43) Starting from (rac) mandelic acid (10.2 $\mathrm{mg}, 0.067 \mathrm{mmol})$ and E-1b $(70 \mathrm{mg}$, $0.067 \mathrm{mmol}$ ) title product (50 mg, yield $63 \%$ ) was obtained by prep HPLC purification as two epimers. $\mathrm{ES}^{+} \mathrm{m} / \mathrm{z} 1179.58[\mathrm{M}+\mathrm{H}]^{+} .{ }^{1} \mathrm{H}$ NMR $(600 \mathrm{MHz}$, DMSO-d $\left.\mathrm{d}_{6}\right) \quad 9.99(\mathrm{~s}, 1 \mathrm{H}), 9.97-9.95(\mathrm{~m}, 1 \mathrm{H}), 9.93(\mathrm{~s}, 1 \mathrm{H}), 8.18-8.15(\mathrm{~m}, 1 \mathrm{H})$, 8.13-8.07 (m, 2H), 7.93-7.88 (m, 1H), 7.46 (d, $J=8.6 \mathrm{~Hz}, 1 \mathrm{H}), 7.44-7.41(\mathrm{~m}$, 2H), 7.41-7.4 (m, 1H), 7.40-7.34 (m, 4H), 7.31-7.22 (m, 8H), 7.22-7.17 (m, $4 \mathrm{H}), 7.17-7.1(\mathrm{~m}, 6 \mathrm{H}), 6.36-6.33(\mathrm{~m}, 1 \mathrm{H}), 6.25-6.21(\mathrm{~m}, 1 \mathrm{H}), 4.95(\mathrm{~d}, J=5 \mathrm{~Hz}$, $1 \mathrm{H}), 4.92(\mathrm{~d}, J=4.4 \mathrm{~Hz}, 1 \mathrm{H}), 4.82-4.78(\mathrm{~m}, 2 \mathrm{H}), 4.76-4.71(\mathrm{~m}, 1 \mathrm{H}), 4.63(\mathrm{br} \mathrm{d}$, 
$J=4.4 \mathrm{~Hz}, 1 \mathrm{H}), 4.45(\mathrm{~d}, J=7.3 \mathrm{~Hz}, 1 \mathrm{H}), 4.38(\mathrm{~d}, J=7.3 \mathrm{~Hz}, 1 \mathrm{H}), 4.29(\mathrm{~d}, J=7.7 \mathrm{~Hz}, 2 \mathrm{H}), 4.23(\mathrm{~d}, J=8.4 \mathrm{~Hz}, 1 \mathrm{H}), 4.18-4.11(\mathrm{~m}$, $2 \mathrm{H}), 4.11-4.08(\mathrm{~m}, 1 \mathrm{H}), 4.08-4(\mathrm{~m}, 5 \mathrm{H}), 4-3.95(\mathrm{~m}, 1 \mathrm{H}), 3.89$ (br s, $1 \mathrm{H}), 3.86-3.83(\mathrm{~m}, 1 \mathrm{H}), 3.71(\mathrm{~d}, J=2 \mathrm{~Hz}, 1 \mathrm{H}), 3.70-3.64$ $(\mathrm{m}, 1 \mathrm{H}), 3.63-3.57(\mathrm{~m}, 1 \mathrm{H}), 3.52(\mathrm{br} \mathrm{d}, J=6.8 \mathrm{~Hz}, 1 \mathrm{H}), 3.48-3.44(\mathrm{~m}, 1 \mathrm{H}), 3.28-3.23(\mathrm{~m}, 1 \mathrm{H}), 3.21(\mathrm{~s}, 4 \mathrm{H}), 3.20-3.16(\mathrm{~m}, 6 \mathrm{H})$, 3.15-3.08 (m, 2H), 3.07-2.96 (m, 4H), 2.94-2.85 (m, 4H), $2.8(\mathrm{~d}, J=1.3 \mathrm{~Hz}, 4 \mathrm{H}), 2.78-2.74(\mathrm{~m}, 1 \mathrm{H}), 2.73-2.67(\mathrm{~m}, 1 \mathrm{H}), 2.64-$ $2.57(\mathrm{~m}, 4 \mathrm{H}), 2.50-2.45(\mathrm{~m}, 2 \mathrm{H}), 2.43-2.38(\mathrm{~m}, 2 \mathrm{H}), 2.30-2.21(\mathrm{~m}, 12 \mathrm{H}), 2.30-2.2(\mathrm{~m}, 1 \mathrm{H}), 2.14-2.1(\mathrm{~m}, 1 \mathrm{H}), 2.10-2.07(\mathrm{~m}$, $1 \mathrm{H}), 1.98(\mathrm{td}, J=13.1,6.7 \mathrm{~Hz}, 3 \mathrm{H}), 1.80-1.75(\mathrm{~m}, 1 \mathrm{H}), 1.64-1.59(\mathrm{~m}, 2 \mathrm{H}), 1.58-1.52(\mathrm{~m}, 1 \mathrm{H}), 1.51-1.45(\mathrm{~m}, 2 \mathrm{H}), 1.44-1.38(\mathrm{~m}$, $1 \mathrm{H}), 1.28-1.23(\mathrm{~m}, 3 \mathrm{H}), 1.22-1.19(\mathrm{~m}, 3 \mathrm{H}), 1.18-1.16(\mathrm{~m}, 8 \mathrm{H}), 1.15-1.13(\mathrm{~m}, 10 \mathrm{H}), 1.12-1.1(\mathrm{~m}, 6 \mathrm{H}), 1.09(\mathrm{br} \mathrm{d}, J=6.1 \mathrm{~Hz}, 8 \mathrm{H})$, $1(\mathrm{br} \mathrm{d}, J=7.2 \mathrm{~Hz}, 4 \mathrm{H}), 0.94(\mathrm{br} \mathrm{d}, J=6.2 \mathrm{~Hz}, 2 \mathrm{H}), 0.91(\mathrm{dd}, J=6.6,1.7 \mathrm{~Hz}, 4 \mathrm{H}), 0.69(\mathrm{t}, J=7 \mathrm{~Hz}, 2 \mathrm{H}), 0.66-0.62(\mathrm{~m}, 2 \mathrm{H}), 0.59$ (dd, $J=9.4,6.8 \mathrm{~Hz}, 4 \mathrm{H}), 0.51$ (dd, $J=11.5,6.7 \mathrm{~Hz}, 4 \mathrm{H}$ ).

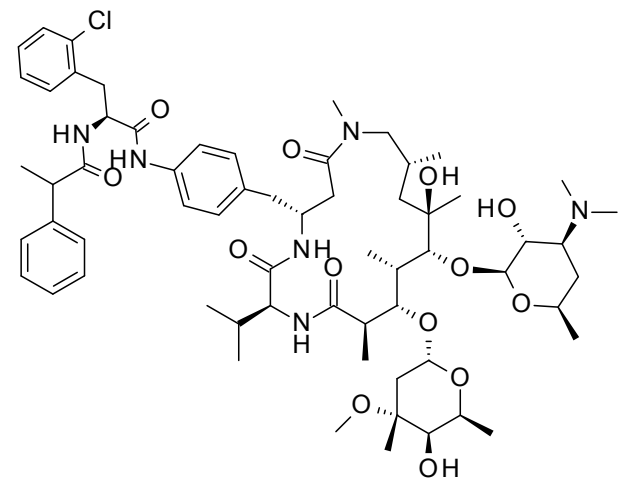

(2S)-3-(2-chlorophenyl)-2-(2-phenylpropanoylamino)- $N$-[4[[(2S,5R,10R,12R,13R,14S,15S,16R)-12-hydroxy-2-isopropyl-8,10,12,14,16pentamethyl-3,7,17-trioxo-13-[(2S,3R,4S,6R)-4-(dimethylamino)-3hydroxy-6-methyl-tetrahydropyran-2-yl]oxy-15-[(2R,4R,5S,6S)-5-hydroxy4-methoxy-4,6-dimethyl-tetrahydropyran-2-yl]oxy-1,4,8triazacycloheptadec-5-yl]methyl]phenyl]propenamide (44) Starting from rac-2-phenylpropionic acid (11mg, $0.73 \mathrm{mmol})$ and E-1b $(60$ $\mathrm{mg}, 0.057 \mathrm{mmol}$ ) title product (30 mg, yield $45 \%$, purity $96.79 \%$ ) was obtained by prep HPLC purification. $\mathrm{ES}^{+} \mathrm{m} / \mathrm{z} 1177.5[\mathrm{M}+\mathrm{H}]^{+}$. Two sets of signals in the NMR (mixture of diasteroisomers). ${ }^{1} \mathrm{H}$ NMR $(500 \mathrm{MHz}$, DMSO$\left.\mathrm{d}_{6}\right) \delta / \mathrm{ppm} 9.98(\mathrm{~s}, 1 \mathrm{H}), 9.93(\mathrm{~s}, 1 \mathrm{H}), 9.89(\mathrm{~m}, 1 \mathrm{H}), 9.85(\mathrm{~s}, 1 \mathrm{H}), 8.38-8.29(\mathrm{~m}$, $3 \mathrm{H}), 8.14-8.06(\mathrm{~m}, 2 \mathrm{H}), 7.93-7.86(\mathrm{~m}, 1 \mathrm{H}), 7.46(\mathrm{~d}, J=8.2 \mathrm{~Hz}, 1 \mathrm{H}), 7.44-7.41$ (m, 3H), 7.41-7.37 (m, 2H), $7.35(\mathrm{br} \mathrm{d}, J=8.5 \mathrm{~Hz}, 2 \mathrm{H}), 7.32(\mathrm{br} \mathrm{d}, J=7 \mathrm{~Hz}, 4 \mathrm{H})$, 7.30-7.2 (m, 24H), 7.20-7.14 (m, 4H), 7.14-7.05 (m, 10H), 7.03-6.97 (m, 2H), 4.81-4.76 (m, 4H), 4.76-4.69 (m, 2H), 4.65-4.6 (m, 2H), 4.45 (br d, $J=7 \mathrm{~Hz}, 2 \mathrm{H}), 4.37(\mathrm{br} \mathrm{d}, J=7 \mathrm{~Hz}, 2 \mathrm{H}), 4.29$ (d, $J=7.9 \mathrm{~Hz}, 3 \mathrm{H}), 4.23(\mathrm{~d}, J=8.2 \mathrm{~Hz}, 2 \mathrm{H}), 4.14-4.01(\mathrm{~m}, 13 \mathrm{H})$, 4-3.93 (m, 2H), 3.89 (br d, $J=2.1 \mathrm{~Hz}, 2 \mathrm{H}), 3.86-3.8(\mathrm{~m}, 4 \mathrm{H}), 3.77-3.68(\mathrm{~m}, 8 \mathrm{H}), 3.68-3.57(\mathrm{~m}, 4 \mathrm{H}), 3.51(\mathrm{br} \mathrm{d}, J=6.1 \mathrm{~Hz}, 4 \mathrm{H})$, 3.45 (br d, $J=2.1 \mathrm{~Hz}, 2 \mathrm{H}), 3.21(\mathrm{~s}, 8 \mathrm{H}), 3.19(\mathrm{~s}, 4 \mathrm{H}), 3.17-3.11(\mathrm{~m}, 2 \mathrm{H}), 3.10-3.03(\mathrm{~m}, 8 \mathrm{H}), 3.02-2.93(\mathrm{~m}, 5 \mathrm{H}), 2.93-2.87(\mathrm{~m}$, $7 \mathrm{H}), 2.79(\mathrm{~d}, J=3.7 \mathrm{~Hz}, 7 \mathrm{H}), 2.71-2.66(\mathrm{~m}, 2 \mathrm{H}), 2.64(\mathrm{br} \mathrm{d}, J=1.8 \mathrm{~Hz}, 2 \mathrm{H}), 2.63-2.55(\mathrm{~m}, 9 \mathrm{H}), 2.49-2.42(\mathrm{~m}, 4 \mathrm{H}), 2.42-2.33(\mathrm{~m}$, $4 \mathrm{H}), 2.25-2.21(\mathrm{~m}, 25 \mathrm{H}), 2.14-2.07(\mathrm{~m}, 3 \mathrm{H}), 2.03-1.93(\mathrm{~m}, 6 \mathrm{H}), 1.82-1.7(\mathrm{~m}, 2 \mathrm{H}), 1.6(\mathrm{br} \mathrm{d}, J=7.9 \mathrm{~Hz}, 4 \mathrm{H}), 1.52-1.44(\mathrm{~m}, 4 \mathrm{H})$, 1.44-1.37 (m, 4H), $1.34(\mathrm{~s}, 2 \mathrm{H}), 1.29(\mathrm{~d}, J=7 \mathrm{~Hz}, 8 \mathrm{H}), 1.27-1.23(\mathrm{~m}, 12 \mathrm{H}), 1.23-1.19(\mathrm{~m}, 12 \mathrm{H}), 1.19-1.15(\mathrm{~m}, 18 \mathrm{H}), 1.15-1.11$ $(\mathrm{m}, 30 \mathrm{H}), 1.09$ (br d, $J=5.8 \mathrm{~Hz}, 14 \mathrm{H}), 0.99(\mathrm{br} \mathrm{d}, J=7 \mathrm{~Hz}, 12 \mathrm{H}), 0.94-0.89(\mathrm{~m}, 10 \mathrm{H}), 0.71-0.66(\mathrm{~m}, 4 \mathrm{H}), 0.65-0.6(\mathrm{~m}, 4 \mathrm{H}), 0.57$ (br dd, $J=9.8,6.7 \mathrm{~Hz}, 7 \mathrm{H}), 0.5$ (br dd, $J=15.0,6.7 \mathrm{~Hz}, 7 \mathrm{H}$ ).

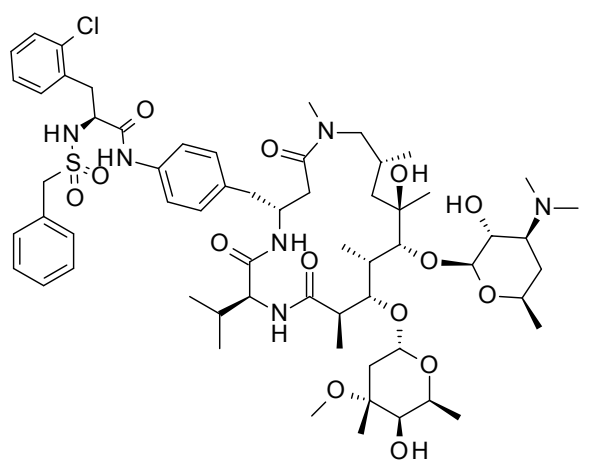

(2S)-2-(benzylsulfonylamino)-3-(2-chlorophenyl)- $N$-[4-

[[(2S,5R,10R,12R,13R,14S,15S,16R)-13-( $\beta$-D-desosaminyl)oxy-12-hydroxy-

15 -( $\alpha$-L-cladinosyl)oxy-2-isopropyl-8,10,12,14,16-pentamethyl-3,7,17-

trioxo-1,4,8-triazacycloheptadec-5-yl]methyl] phenyl]propenamide (47)

To a solution of E-1b (85 mg, $0.08 \mathrm{mmol})$ in dry DCM $(2 \mathrm{~mL})$, TEA $(0.017 \mathrm{~mL}$, $0.14 \mathrm{mmol}$ ) and phenylmethanesulfonly chloride (16 $\mathrm{mg}, 0.08 \mathrm{mmol})$ was added and stirred at RT for $1 \mathrm{~h}$. Reaction mixture was evaporated to obtain crude product. The crude product was purified by prep HPLC purification to get title compound (10 mg, yield $21 \%, 93.86 \%)$. $\mathrm{ES}^{+} \mathrm{m} / \mathrm{z} 1200.31[\mathrm{M}+\mathrm{H}]^{+}$. Two sets of signals in the NMR (most likely conformers). ${ }^{1} \mathrm{H}$ NMR $(500 \mathrm{MHz}$, DMSO-d $\left.\mathrm{d}_{6}\right) \delta / \mathrm{ppm} 10.01(\mathrm{~s}, 1 \mathrm{H}), 9.99(\mathrm{~s}, 1 \mathrm{H}), 8.1(\mathrm{br} \mathrm{d}, J=8.9 \mathrm{~Hz}, 1 \mathrm{H}), 7.96(\mathrm{br}$ $\mathrm{d}, J=8.2 \mathrm{~Hz}, 1 \mathrm{H}), 7.84(\mathrm{br} \mathrm{s}, 2 \mathrm{H}), 7.46-7.42(\mathrm{~m}, 6 \mathrm{H}), 7.42-7.38(\mathrm{~m}, 8 \mathrm{H}), 7.37-$ $7.32(\mathrm{~m}, 3 \mathrm{H}), 7.32-7.28(\mathrm{~m}, 6 \mathrm{H}), 7.28-7.21(\mathrm{~m}, 7 \mathrm{H}), 7.12(\mathrm{~d}, J=8.2 \mathrm{~Hz}, 3 \mathrm{H})$, $4.83(\mathrm{br} \mathrm{d}, J=4.3 \mathrm{~Hz}, 2 \mathrm{H}), 4.72(\mathrm{~s}, 1 \mathrm{H}), 4.70-4.67(\mathrm{~m}, 2 \mathrm{H}), 4.65(\mathrm{~s}, 1 \mathrm{H}), 4.63-4.61(\mathrm{~m}, 1 \mathrm{H}), 4.45(\mathrm{br} \mathrm{d}, J=7 \mathrm{~Hz}, 1 \mathrm{H}), 4.37$ (br dd, $J=10.1,6.4 \mathrm{~Hz}, 2 \mathrm{H}), 4.32-4.28(\mathrm{~m}, 3 \mathrm{H}), 4.20-4.15(\mathrm{~m}, 2 \mathrm{H}), 4.15-4.09(\mathrm{~m}, 4 \mathrm{H}), 4.06-3.99(\mathrm{~m}, 2 \mathrm{H}), 3.92(\mathrm{~s}, 1 \mathrm{H}), 3.86(\mathrm{br} \mathrm{d}, J=$ $7.9 \mathrm{~Hz}, 1 \mathrm{H}), 3.66(\mathrm{~s}, 1 \mathrm{H}), 3.59-3.5(\mathrm{~m}, 2 \mathrm{H}), 3.44(\mathrm{br} \mathrm{d}, J=6.4 \mathrm{~Hz}, 2 \mathrm{H}), 3.42-3.39(\mathrm{~m}, 1 \mathrm{H}), 3.31-3.26(\mathrm{~m}, 1 \mathrm{H}), 3.23-3.21(\mathrm{~m}, 4 \mathrm{H})$, $3.21-3.19(\mathrm{~m}, 1 \mathrm{H}), 3.15-3.03(\mathrm{~m}, 6 \mathrm{H}), 3(\mathrm{br} \mathrm{d}, J=11.6 \mathrm{~Hz}, 1 \mathrm{H}), 2.9(\mathrm{~s}, 1 \mathrm{H}), 2.8(\mathrm{~s}, 4 \mathrm{H}), 2.72(\mathrm{br} \mathrm{d}, J=7.3 \mathrm{~Hz}, 1 \mathrm{H}), 2.61-2.54(\mathrm{~m}$, $4 \mathrm{H}), 2.45-2.37(\mathrm{~m}, 2 \mathrm{H}), 2.33-2.28(\mathrm{~m}, 2 \mathrm{H}), 2.28-2.25(\mathrm{~m}, 9 \mathrm{H}), 2.15-2.08(\mathrm{~m}, 1 \mathrm{H}), 2.01-1.89(\mathrm{~m}, 2 \mathrm{H}), 1.82-1.74(\mathrm{~m}, 1 \mathrm{H}), 1.72-$ $1.65(\mathrm{~m}, 1 \mathrm{H}), 1.65-1.57(\mathrm{~m}, 2 \mathrm{H}), 1.36-1.28(\mathrm{~m}, 2 \mathrm{H}), 1.27-1.23(\mathrm{~m}, 3 \mathrm{H}), 1.21(\mathrm{br} \mathrm{d}, J=5.8 \mathrm{~Hz}, 6 \mathrm{H}), 1.19(\mathrm{br} \mathrm{d}, J=3.1 \mathrm{~Hz}, 3 \mathrm{H})$, 1.18-1.14 (m, 7H), 1.11-1.08 (m, 2H), 1.07-1.02 (m, 7H), 1.01-0.97 (m, 8H), 0.94-0.88 (m, 4H), $0.65(\mathrm{~d}, J=6.4 \mathrm{~Hz}, 3 \mathrm{H}), 0.52$ (br d, $J=6.4 \mathrm{~Hz}, 5 \mathrm{H}), 0.49(\mathrm{br} \mathrm{d}, J=6.7 \mathrm{~Hz}, 4 \mathrm{H})$.

\section{Urea Synthesis}

\section{General procedure for compounds 48-55}

To a solution of E-1b (1 eq) in dry DCM (2 mL), corresponding isocyanate (1 eq) was added and stirred at room temperature for $1 \mathrm{~h}$. Reaction mixture was evaporated to obtain crude product. The crude product was purified by prep HPLC purification (extended A, high $\mathrm{pH}$ ) or by column chromatography using DCM:MeOH: $\mathrm{NH}_{4} \mathrm{OH}=10: 1: 0.1$ as eluent to get title compound. 


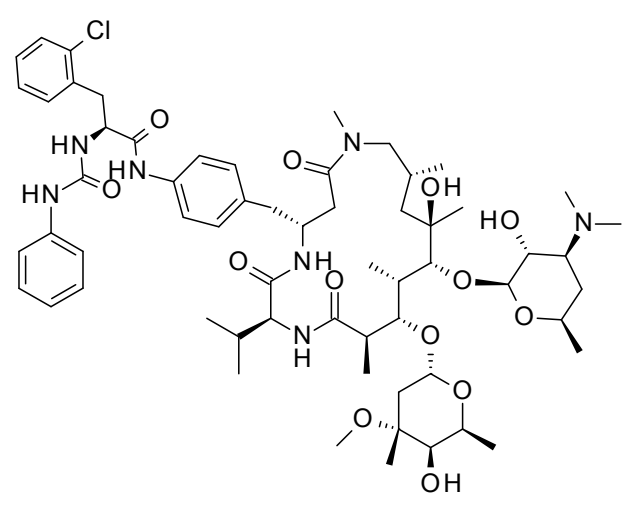

(2S)-3-(2-chlorophenyl)- $N$-[4-[[(2S,5R,10R,12R,13R,14S,15S,16R)-13-( $\beta$-Ddesosaminyl)oxy-12-hydroxy-15-( $\alpha$-L-cladinosyl)oxy-2-isopropyl8,10,12,14,16-pentamethyl-3,7,17-trioxo-1,4,8-triazacycloheptadec-5yl]methyl]phenyl]-2-(phenylcarbamoylamino)propanamide (48) Starting from phenyl isocyanate $(0.0073 \mathrm{~mL}, 0.067 \mathrm{mmol})$ and E- $1 \mathrm{~b}(70 \mathrm{mg}$, $0.067 \mathrm{mmol}$ ) title product ( $71 \mathrm{mg}$, yield $91 \%$, purity $98.5 \%$ ) was obtained by column chromatography purification. $\mathrm{ES}^{+} \mathrm{m} / \mathrm{z} 1164.58[\mathrm{M}+\mathrm{H}]^{+} .{ }^{1} \mathrm{H}$ NMR (500 MHz, DMSO-d $\left.\mathrm{d}_{6}\right) \delta / \mathrm{ppm} 10.11(\mathrm{~m}, 1 \mathrm{H}), 10.07(\mathrm{~s}, 1 \mathrm{H}), 8.7(\mathrm{~s}, 3 \mathrm{H}), 8.11(\mathrm{br}$ $\mathrm{d}, J=8.2 \mathrm{~Hz}, 2 \mathrm{H}), 7.9(\mathrm{br} \mathrm{d}, J=8.9 \mathrm{~Hz}, 2 \mathrm{H}), 7.47-7.37(\mathrm{~m}, 5 \mathrm{H}), 7.36-7.19(\mathrm{~m}$, $13 \mathrm{H}), 7.16-7.08(\mathrm{~m}, 3 \mathrm{H}), 6.9(\mathrm{t}, J=7.3 \mathrm{~Hz}, 2 \mathrm{H}), 6.51(\mathrm{~d}, J=8.5 \mathrm{~Hz}, 2 \mathrm{H}), 4.84-$ $4.69(\mathrm{~m}, 3 \mathrm{H}), 4.63(\mathrm{br} \mathrm{d}, J=4.6 \mathrm{~Hz}, 2 \mathrm{H}), 4.45(\mathrm{~d}, J=7.3 \mathrm{~Hz}, 2 \mathrm{H}), 4.37$ (d, $J=7.3$ $\mathrm{Hz}, 2 \mathrm{H}), 4.29$ (d, $J=7.6 \mathrm{~Hz}, 2 \mathrm{H}), 4.23(\mathrm{~d}, J=8.5 \mathrm{~Hz}, 2 \mathrm{H}), 4.14(\mathrm{br} \mathrm{s}, 2 \mathrm{H}), 4.11-$ $3.95(\mathrm{~m}, 6 \mathrm{H}), 3.89(\mathrm{~s}, 2 \mathrm{H}), 3.83(\mathrm{br} \mathrm{d}, J=7.6 \mathrm{~Hz}, 2 \mathrm{H}), 3.7(\mathrm{~s}, 3 \mathrm{H}), 3.69-3.65(\mathrm{~m}$, $1 \mathrm{H}), 3.63-3.56(\mathrm{~m}, 1 \mathrm{H}), 3.51(\mathrm{br} \mathrm{d}, J=6.7 \mathrm{~Hz}, 2 \mathrm{H}), 3.45(\mathrm{br} \mathrm{d}, J=5.5 \mathrm{~Hz}, 2 \mathrm{H})$, 3.26-3.03 (m, 12H), 3.02-2.95 (m, 2H), 2.94-2.85 (m, 5H), $2.8(\mathrm{~s}, 6 \mathrm{H}), 2.72-2.53(\mathrm{~m}, 5 \mathrm{H}), 2.49-2.46(\mathrm{~m}, 1 \mathrm{H}), 2.44-2.33(\mathrm{~m}$, $3 \mathrm{H}), 2.24(\mathrm{~s}, 10 \mathrm{H}), 2.1(\mathrm{br} \mathrm{s}, 2 \mathrm{H}), 2.03-1.9(\mathrm{~m}, 3 \mathrm{H}), 1.76(\mathrm{dq}, J=13.7,6.7 \mathrm{~Hz}, 2 \mathrm{H}), 1.61(\mathrm{br} \mathrm{d}, J=7 \mathrm{~Hz}, 2 \mathrm{H}), 1.55-1.37(\mathrm{~m}, 3 \mathrm{H})$, $1.31-1.22(\mathrm{~m}, 2 \mathrm{H}), 1.21-1.06(\mathrm{~m}, 26 \mathrm{H}), 0.99(\mathrm{br} \mathrm{d}, J=7.3 \mathrm{~Hz}, 7 \mathrm{H}), 0.96-0.87(\mathrm{~m}, 7 \mathrm{H}), 0.68(\mathrm{~d}, J=6.7 \mathrm{~Hz}, 3 \mathrm{H}), 0.63(\mathrm{br} \mathrm{d}, J=6.7$ $\mathrm{Hz}, 3 \mathrm{H}), 0.58(\mathrm{~d}, J=6.7 \mathrm{~Hz}, 3 \mathrm{H}), 0.5(\mathrm{~d}, J=6.7 \mathrm{~Hz}, 3 \mathrm{H})$.

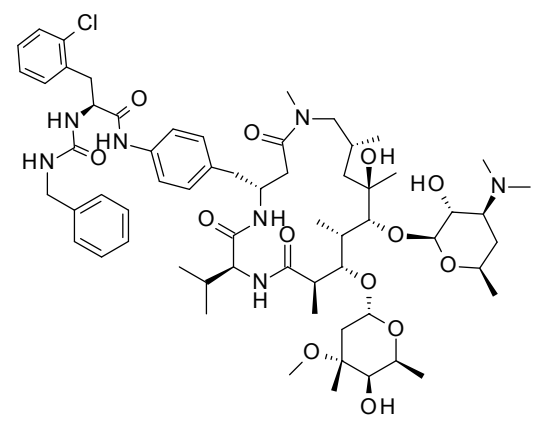

(2S)-2-(benzylcarbamoylamino)-3-(2-chlorophenyl)- $N$-[4-

[[(2S,5R,10R,12R,13R,14S,15S,16R)-13-( $\beta$-D-desosaminyl)oxy-12-hydroxy-15- $(\alpha-$ L-cladinosyl)oxy-2-isopropyl-8,10,12,14,16-pentamethyl-3,7,17-trioxo-1,4,8triazacycloheptadec-5-yl]methyl]phenyl]propanamide (49)

Starting from benzyl isocyanate $(9 \mathrm{mg}, 0.067 \mathrm{mmol})$ and E-1b $(70 \mathrm{mg}, 0.067 \mathrm{mmol})$ title product (62 $\mathrm{mg}$, yield $78 \%$, purity $99.14 \%$ ) was obtained by column chromatography purification. ES $\mathrm{m} / \mathrm{z} 1178.58[\mathrm{M}+\mathrm{H}]^{+} .{ }^{1} \mathrm{H}$ NMR $(500 \mathrm{MHz}$, DMSO$\left.\mathrm{d}_{6}\right) \delta / \mathrm{ppm} 10(\mathrm{~s}, 1 \mathrm{H}), 9.97(\mathrm{~s}, 1 \mathrm{H}), 8.1(\mathrm{br} \mathrm{d}, J=8.5 \mathrm{~Hz}, 2 \mathrm{H}), 7.9(\mathrm{br} \mathrm{d}, J=8.9 \mathrm{~Hz}, 2 \mathrm{H})$, 7.45 (d, $J=8.2 \mathrm{~Hz}, 2 \mathrm{H}), 7.41$ (d, $J=8.5 \mathrm{~Hz}, 2 \mathrm{H}), 7.39$ (dd, $J=7.0,2.1 \mathrm{~Hz}, 2 \mathrm{H}), 7.34-$ $7.29(\mathrm{~m}, 3 \mathrm{H}), 7.27$ (d, $J=7.3 \mathrm{~Hz}, 4 \mathrm{H}), 7.25-7.19(\mathrm{~m}, 6 \mathrm{H}), 7.17(\mathrm{br} \mathrm{d}, J=7.3 \mathrm{~Hz}, 3 \mathrm{H})$, $7.13-7.06(\mathrm{~m}, 4 \mathrm{H}), 6.58(\mathrm{dt}, J=5.9,3 \mathrm{~Hz}, 2 \mathrm{H}), 6.35(\mathrm{br} \mathrm{d}, J=8.5 \mathrm{~Hz}, 2 \mathrm{H}), 6.34(\mathrm{br} \mathrm{d}, J$ $=8.5 \mathrm{~Hz}, 2 \mathrm{H}), 4.79(\mathrm{br} \mathrm{d}, J=4.6 \mathrm{~Hz}, 2 \mathrm{H}), 4.72-4.65(\mathrm{~m}, 2 \mathrm{H}), 4.62(\mathrm{br} \mathrm{d}, J=4.3 \mathrm{~Hz}, 2 \mathrm{H}), 4.44(\mathrm{br} \mathrm{d}, J=7.3 \mathrm{~Hz}, 2 \mathrm{H}), 4.36(\mathrm{br} \mathrm{d}, J=$ $7.3 \mathrm{~Hz}, 2 \mathrm{H}), 4.28(\mathrm{~d}, J=7.9 \mathrm{~Hz}, 2 \mathrm{H}), 4.28-4.24(\mathrm{~m}, 2 \mathrm{H}), 4.22(\mathrm{~d}, J=7.9 \mathrm{~Hz}, 2 \mathrm{H}), 4.18$ (dd, $J=9.0,6.3 \mathrm{~Hz}, 4 \mathrm{H}), 4.14$ (br d, $J=5.8$ $\mathrm{Hz}, 2 \mathrm{H}), 4.08-3.99(\mathrm{~m}, 4 \mathrm{H}), 3.88(\mathrm{~s}, 1 \mathrm{H}), 3.83(\mathrm{br} \mathrm{d}, J=7.9 \mathrm{~Hz}, 1 \mathrm{H}), 3.69(\mathrm{~s}, 1 \mathrm{H}), 3.66(\mathrm{br} \mathrm{dq}, J=10.5,6.3 \mathrm{~Hz}, 1 \mathrm{H}), 3.62-3.55(\mathrm{~m}$, $1 \mathrm{H}), 3.51(\mathrm{br} \mathrm{d}, J=7 \mathrm{~Hz}, 2 \mathrm{H}), 3.45(\mathrm{br} \mathrm{d}, J=5.2 \mathrm{~Hz}, 2 \mathrm{H}), 3.24(\mathrm{br} \mathrm{d}, J=8.9 \mathrm{~Hz}, 2 \mathrm{H}), 3.2(\mathrm{~s}, 4 \mathrm{H}), 3.18(\mathrm{~s}, 2 \mathrm{H}), 3.14-2.99(\mathrm{~m}, 8 \mathrm{H})$, 2.99-2.94 (m, 2H), 2.9 (br t, $J=8.9 \mathrm{~Hz}, 2 \mathrm{H}), 2.88(\mathrm{~s}, 2 \mathrm{H}), 2.79(\mathrm{~s}, 3 \mathrm{H}), 2.63-2.54(\mathrm{~m}, 4 \mathrm{H}), 2.46(\mathrm{br} \mathrm{t}, J=10.5 \mathrm{~Hz}, 2 \mathrm{H}), 2.42-2.32$ $(\mathrm{m}, 2 \mathrm{H}), 2.26(\mathrm{br} \mathrm{d}, J=15 \mathrm{~Hz}, 2 \mathrm{H}), 2.22(\mathrm{~s}, 10 \mathrm{H}), 2.15-2.03(\mathrm{~m}, 2 \mathrm{H}), 2.02-1.91(\mathrm{~m}, 2 \mathrm{H}), 1.76(\mathrm{dq}, J=13.7,6.7 \mathrm{~Hz}, 1 \mathrm{H}), 1.6(\mathrm{br}$ d, $J=7.3 \mathrm{~Hz}, 2 \mathrm{H}), 1.48(\mathrm{br} \mathrm{dd}, J=14.8,4.7 \mathrm{~Hz}, 1 \mathrm{H}), 1.45-1.39(\mathrm{~m}, 1 \mathrm{H}), 1.38(\mathrm{br} \mathrm{s}, 1 \mathrm{H}), 1.29-1.21(\mathrm{~m}, 2 \mathrm{H}), 1.19(\mathrm{~s}, 2 \mathrm{H}), 1.17-$ $1.08(\mathrm{~m}, 20 \mathrm{H}), 1.08(\mathrm{br} \mathrm{d}, J=6.1 \mathrm{~Hz}, 4 \mathrm{H}), 0.98(\mathrm{br} \mathrm{d}, J=7 \mathrm{~Hz}, 8 \mathrm{H}), 0.92(\mathrm{br} \mathrm{d}, J=6.4 \mathrm{~Hz}, 3 \mathrm{H}), 0.9$ (br d, $J=6.4 \mathrm{~Hz}, 3 \mathrm{H}), 0.68(\mathrm{br}$ d, $J=6.7 \mathrm{~Hz}, 3 \mathrm{H}), 0.62(\mathrm{br} \mathrm{d}, J=6.7 \mathrm{~Hz}, 3 \mathrm{H}), 0.57(\mathrm{br} \mathrm{d}, J=6.7 \mathrm{~Hz}, 3 \mathrm{H}), 0.5(\mathrm{br} \mathrm{d}, J=6.7 \mathrm{~Hz}, 3 \mathrm{H})$.

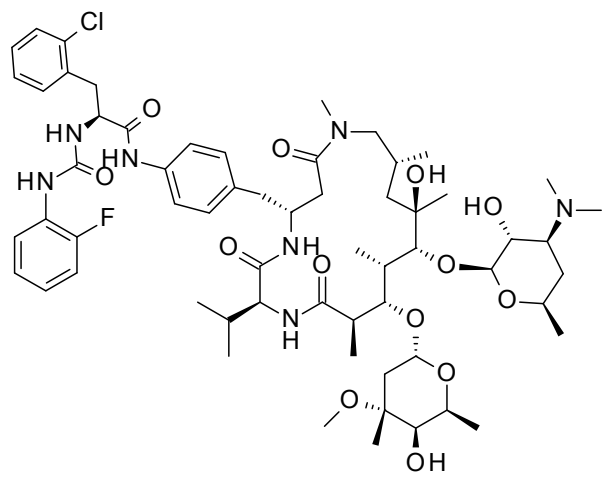

(2S)-3-(2-chlorophenyl)- $N$-[4-[[(2S,5R,10R,12R,13R,14S,15S,16R)-13-( $\beta$-Ddesosaminyl)oxy-12-hydroxy-15-( $\alpha$-L-cladinosyl)oxy-2-isopropyl8,10,12,14,16-pentamethyl-3,7,17-trioxo-1,4,8-triazacycloheptadec-5yl]methyl]phenyl]-2-[(2-fluorophenyl)carbamoylamino]propanamide (50) Starting from 2-fluorophenyl isocyanate $(0.0128 \mathrm{~mL}, 0.11 \mathrm{mmol})$ and $\mathbf{E - 1 b}$ (120 mg, $0.11 \mathrm{mmol}$ ) title product (29 $\mathrm{mg}$, yield $23 \%$, purity $98.1 \%$ ) was obtained by prep HPLC purification. ES ${ }^{+} \mathrm{m} / \mathrm{z} 1183.68[\mathrm{M}+\mathrm{H}]^{+}$. Two sets of signals in the NMR (most likely conformers). ${ }^{1} \mathrm{H}$ NMR (500 MHz, DMSO- $\mathrm{d}_{6}$ ) $\delta / \mathrm{ppm} 10.11(\mathrm{~s}, 1 \mathrm{H}), 10.08(\mathrm{~s}, 1 \mathrm{H}), 8.56(\mathrm{~s}, 3 \mathrm{H}), 8.11(\mathrm{br} \mathrm{d}, \mathrm{J}=8.5 \mathrm{~Hz}, 2 \mathrm{H}), 8.06$ (td, $J=8.3,1.4 \mathrm{~Hz}, 2 \mathrm{H}), 7.9(\mathrm{br} \mathrm{d}, J=10.1 \mathrm{~Hz}, 2 \mathrm{H}), 7.48-7.37(\mathrm{~m}, 5 \mathrm{H}), 7.36-7.3$ (m, 2H), 7.29-7.21 (m, 5H), 7.20-7.1 (m, 7H), $7.06(\mathrm{t}, J=7.6 \mathrm{~Hz}, 2 \mathrm{H}), 6.95-6.9$ (m, 2H), 4.83-4.7 (m, 3H), $4.63(\mathrm{br} \mathrm{d}, J=4.9 \mathrm{~Hz}, 2 \mathrm{H}), 4.45(\mathrm{~d}, J=7.3 \mathrm{~Hz}, 2 \mathrm{H})$, $4.37(\mathrm{br} \mathrm{d}, J=7 \mathrm{~Hz}, 2 \mathrm{H}), 4.29(\mathrm{~d}, J=7.6 \mathrm{~Hz}, 2 \mathrm{H}), 4.23(\mathrm{~d}, J=8.2 \mathrm{~Hz}, 2 \mathrm{H}), 4.13$ (br s, 1H), 4.10-3.95 (m, 5H), 3.89 (s, 1H), $3.83(\mathrm{br} \mathrm{d}, J=8.2 \mathrm{~Hz}, 2 \mathrm{H}), 3.7(\mathrm{~s}, 1 \mathrm{H}), 3.67$ (br dd, $J=10.4,6.1 \mathrm{~Hz}, 2 \mathrm{H}), 3.62-3.56$ (m, 1H), 3.51 (br d, $J=7 \mathrm{~Hz}, 2 \mathrm{H}), 3.48-3.43(\mathrm{~m}, 2 \mathrm{H}), 3.28-3.23(\mathrm{~m}, 1 \mathrm{H}), 3.21(\mathrm{~s}, 3 \mathrm{H}), 3.18(\mathrm{~s}, 3 \mathrm{H}), 3.17-3.05(\mathrm{~m}, 5 \mathrm{H}), 3.04-2.95$ $(\mathrm{m}, 2 \mathrm{H}), 2.94-2.85(\mathrm{~m}, 4 \mathrm{H}), 2.82-2.74(\mathrm{~m}, 4 \mathrm{H}), 2.73-2.66(\mathrm{~m}, 1 \mathrm{H}), 2.63-2.56(\mathrm{~m}, 3 \mathrm{H}), 2.53-2.52(\mathrm{~m}, 1 \mathrm{H}), 2.48-2.39(\mathrm{~m}, 4 \mathrm{H})$, 2.3-2.16 (m, 13H), 2.09 (s, 2H), 2.03-1.89 (m, 3H), $1.76(\mathrm{dq}, J=13.7,6.7 \mathrm{~Hz}, 2 \mathrm{H}), 1.6(\mathrm{br} \mathrm{d}, J=7.3 \mathrm{~Hz}, 2 \mathrm{H}), 1.55-1.37(\mathrm{~m}, 3 \mathrm{H})$, $1.32-1.22(\mathrm{~m}, 3 \mathrm{H}), 1.21-1.06(\mathrm{~m}, 28 \mathrm{H}), 0.99(\mathrm{br} \mathrm{d}, J=7.3 \mathrm{~Hz}, 5 \mathrm{H}), 0.96-0.86(\mathrm{~m}, 6 \mathrm{H}), 0.68(\mathrm{~d}, J=6.7 \mathrm{~Hz}, 3 \mathrm{H}), 0.63(\mathrm{br} d, J=6.7$ $\mathrm{Hz}, 3 \mathrm{H}), 0.58(\mathrm{~d}, J=6.7 \mathrm{~Hz}, 3 \mathrm{H}), 0.5(\mathrm{~d}, J=6.7 \mathrm{~Hz}, 3 \mathrm{H})$. 


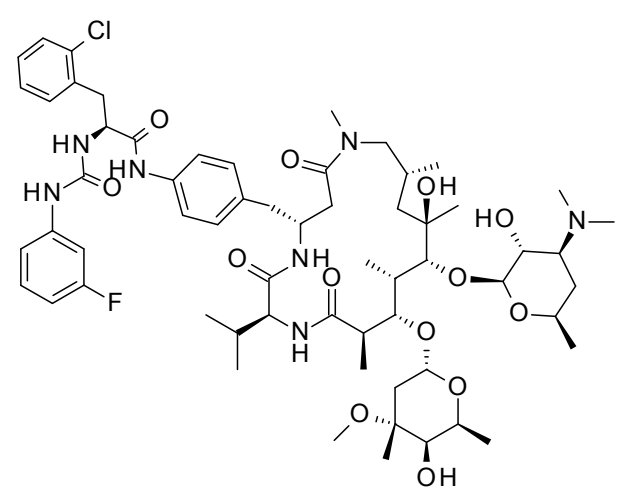

(2S)-3-(2-chlorophenyl)- $N$-[4-[[(2S,5R,10R,12R,13R,14S,15S,16R)-13-( $\beta$-Ddesosaminyl)oxy-12-hydroxy-15-( $\alpha$-L-cladinosyl)oxy-2-isopropyl8,10,12,14,16-pentamethyl-3,7,17-trioxo-1,4,8-triazacycloheptadec-5yl]methyl]phenyl]-2-[(3-fluorophenyl)carbamoylamino]propanamide (51) Starting from 3-fluoro isocyanate (14 mg, $0.12 \mathrm{mmol})$ and E1-b (127 mg, 0.12 mmol) title product ( $50 \mathrm{mg}$, yield $35 \%$, purity $99.1 \%$ ) was obtained by prep HPLC purification. $\mathrm{ES}^{+} \mathrm{m} / \mathrm{z} 1182.52[\mathrm{M}+\mathrm{H}]^{+}$. Two sets of signals in the NMR (most likely conformers). ${ }^{1} \mathrm{H}$ NMR $\left(500 \mathrm{MHz}\right.$, DMSO-d $\left.\mathrm{d}_{6}\right) \delta / \mathrm{ppm} 10.11(\mathrm{~s}, 1 \mathrm{H})$, 10.08 (s, $1 \mathrm{H}$ ), $8.97-8.93(\mathrm{~m}, 2 \mathrm{H}), 8.11$ (br d, $J=8.9 \mathrm{~Hz}, 1 \mathrm{H}$ ), 7.9 (br d, $J=9.5$ $\mathrm{Hz}, 1 \mathrm{H}), 7.45$ (br d, $J=8.2 \mathrm{~Hz}, 1 \mathrm{H}), 7.44-7.38(\mathrm{~m}, 6 \mathrm{H}), 7.35-7.3(\mathrm{~m}, 2 \mathrm{H}), 7.30-$ $7.21(\mathrm{~m}, 8 \mathrm{H}), 7.15-7.07(\mathrm{~m}, 4 \mathrm{H}), 7.01-6.96(\mathrm{~m}, 2 \mathrm{H}), 6.71(\mathrm{td}, J=8.5,2.4 \mathrm{~Hz}$, $2 \mathrm{H}), 6.58(\mathrm{br} \mathrm{d}, J=8.5 \mathrm{~Hz}, 2 \mathrm{H}), 4.79(\mathrm{br} \mathrm{d}, J=4.6 \mathrm{~Hz}, 1 \mathrm{H}), 4.74(\mathrm{q}, J=7.2 \mathrm{~Hz}$, $2 \mathrm{H}), 4.63(\mathrm{br} \mathrm{d}, J=4 \mathrm{~Hz}, 1 \mathrm{H}), 4.45(\mathrm{~d}, J=7 \mathrm{~Hz}, 1 \mathrm{H}), 4.37(\mathrm{br} \mathrm{d}, J=7 \mathrm{~Hz}, 1 \mathrm{H})$, 4.29 (d, J = 7.6 Hz, 2H), 4.25-4.22 (m, 1H), 4.18-4.09 (m, 3H), 4.08-4 (m, 5H), $3.89(\mathrm{~s}, 1 \mathrm{H}), 3.83(\mathrm{br} \mathrm{d}, J=7.9 \mathrm{~Hz}, 1 \mathrm{H}), 3.73-3.63(\mathrm{~m}, 3 \mathrm{H}), 3.51(\mathrm{br} \mathrm{d}, J=7 \mathrm{~Hz}, 2 \mathrm{H}), 3.45$ (br d, $J=4.9 \mathrm{~Hz}, 1 \mathrm{H}), 3.21(\mathrm{~s}, 4 \mathrm{H}), 3.18$ (s, 3H), 3.17-3.1 (m, 4H), 3.10-2.96 (m, 5H), 2.93-2.85 (m, 5H), 2.82-2.76 (m, 5H), 2.75-2.67 (m, 1H), 2.65-2.55 (m, 5H), 2.40-2.35 (m, 3H), 2.23 (s, 14H), 2.02-1.94 (m, 3H), 1.80-1.72 (m, 1H), $1.61(\mathrm{br} \mathrm{d}, J=7.9 \mathrm{~Hz}, 2 \mathrm{H}), 1.52-1.36(\mathrm{~m}, 3 \mathrm{H}), 1.27-$ $1.22(\mathrm{~m}, 2 \mathrm{H}), 1.2(\mathrm{~s}, 2 \mathrm{H}), 1.18-1.15(\mathrm{~m}, 7 \mathrm{H}), 1.15-1.11(\mathrm{~m}, 16 \mathrm{H}), 1.09(\mathrm{br} \mathrm{d}, J=5.5 \mathrm{~Hz}, 7 \mathrm{H}), 0.99(\mathrm{br} \mathrm{d}, J=7 \mathrm{~Hz}, 7 \mathrm{H}), 0.95-0.87$ $(\mathrm{m}, 7 \mathrm{H}), 0.68(\mathrm{br} \mathrm{d}, J=6.7 \mathrm{~Hz}, 2 \mathrm{H}), 0.62(\mathrm{br} \mathrm{d}, J=6.7 \mathrm{~Hz}, 2 \mathrm{H}), 0.57(\mathrm{br} \mathrm{d}, J=6.4 \mathrm{~Hz}, 4 \mathrm{H}), 0.5(\mathrm{br} \mathrm{d}, J=6.4 \mathrm{~Hz}, 4 \mathrm{H})$.

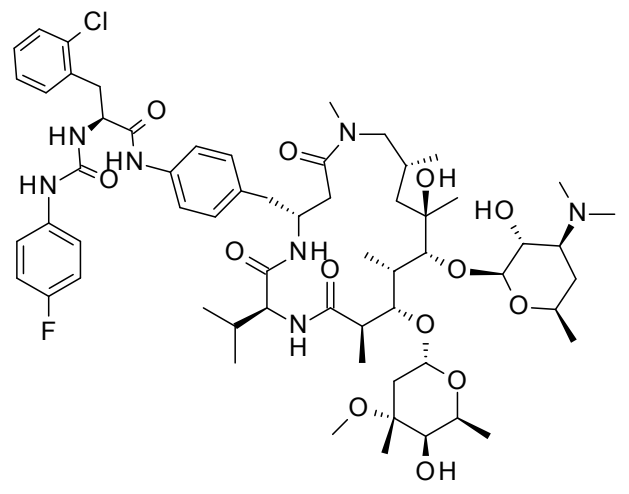

(2S)-3-(2-chlorophenyl)- $N$-[4-[[(2S,5R,10R,12R,13R,14S,15S,16R)-13-( $\beta$-Ddesosaminyl)oxy-12-hydroxy-15-( $\alpha$-L-cladinosyl)oxy-2-isopropyl8,10,12,14,16-pentamethyl-3,7,17-trioxo-1,4,8-triazacycloheptadec-5yl]methyl]phenyl]-2-[(4-fluorophenyl)carbamoylamino]propanamide (52) Starting from 4-fluorophenyl isocyanate $(0.0067 \mathrm{~mL}, 0.059 \mathrm{mmol})$ and $\mathbf{E - 1 b}$ (62.5 mg, $0.059 \mathrm{mmol}$ ) title product $(6.36 \mathrm{mg}$, yield $9 \%$, purity $94 \%$ ) was obtained by prep HPLC purification. $\mathrm{ES}^{+} \mathrm{m} / \mathrm{z} 1182.6[\mathrm{M}+\mathrm{H}]^{+}$. Two sets of signals in the NMR (most likely conformers). ${ }^{1} \mathrm{H}$ NMR (500 MHz, DMSO- $\mathrm{d}_{6}$ ) $\delta /$ ppm 10.09 (s, 1H), 10.05 (s, 1H), 8.78-8.73 (m, 2H), 8.73-8.72 (m, 1H), 8.12 $(\mathrm{d}, J=8.9 \mathrm{~Hz}, 2 \mathrm{H}), 7.9(\mathrm{~d}, J=8.5 \mathrm{~Hz}, 2 \mathrm{H}), 7.46-7.37(\mathrm{~m}, 9 \mathrm{H}), 7.36-7.29(\mathrm{~m}, 9 \mathrm{H})$, 7.28-7.2 (m, 8H), 7.15-7.09 (m, 7H), $7.04(\mathrm{~s}, 2 \mathrm{H}), 7.01(\mathrm{br} \mathrm{d}, J=1.8 \mathrm{~Hz}, 2 \mathrm{H})$, $6.47(\mathrm{~d}, J=8.2 \mathrm{~Hz}, 2 \mathrm{H}), 4.76(\mathrm{~d}, J=4.6 \mathrm{~Hz}, 2 \mathrm{H}), 4.73-4.68(\mathrm{~m}, 2 \mathrm{H}), 4.58(\mathrm{~s}, 1 \mathrm{H})$, $4.44(\mathrm{~d}, J=7.3 \mathrm{~Hz}, 2 \mathrm{H}), 4.40-4.33(\mathrm{~m}, 2 \mathrm{H}), 4.3(\mathrm{~d}, J=8.5 \mathrm{~Hz}, 2 \mathrm{H}), 4.06-3.93(\mathrm{~m}$, 9H), 3.75 (br s, 2H), 3.19 (s, 4H), 3.17 (s, 2H), 3.15-3.05 (m, 8H), 2.93-2.87 (m, 4H), $2.8(\mathrm{~s}, 3 \mathrm{H}), 2.62-2.56(\mathrm{~m}, 4 \mathrm{H}), 2.25-2.21(\mathrm{~m}, 12 \mathrm{H}), 2.01-1.95(\mathrm{~m}, 3 \mathrm{H}), 1.80-1.75(\mathrm{~m}, 2 \mathrm{H}), 1.64-1.58(\mathrm{~m}, 2 \mathrm{H}), 1.52-$ $1.46(\mathrm{~m}, 1 \mathrm{H}), 1.26-1.23(\mathrm{~m}, 4 \mathrm{H}), 1.21-1.15(\mathrm{~m}, 12 \mathrm{H}), 1.15-1.12(\mathrm{~m}, 12 \mathrm{H}), 1.12-1.07(\mathrm{~m}, 12 \mathrm{H}), 0.99(\mathrm{br} \mathrm{d}, J=7.3 \mathrm{~Hz}, 5 \mathrm{H}), 0.94-$ $0.9(\mathrm{~m}, 5 \mathrm{H}), 0.69(\mathrm{~d}, J=6.7 \mathrm{~Hz}, 3 \mathrm{H}), 0.63(\mathrm{~d}, J=6.7 \mathrm{~Hz}, 3 \mathrm{H}), 0.58(\mathrm{~d}, J=6.7 \mathrm{~Hz}, 3 \mathrm{H}), 0.51(\mathrm{~d}, J=6.7 \mathrm{~Hz}, 3 \mathrm{H})$.

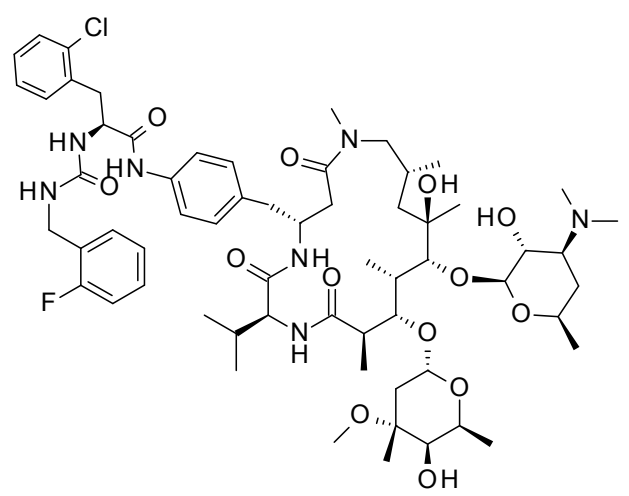

(2S)-3-(2-chlorophenyl)- $N$-[4-[[(2S,5R,10R,12R,13R,14S,15S,16R)-13-( $\beta$-Ddesosaminyl)oxy-12-hydroxy-15-( $\alpha$-L-cladinosyl)oxy-2-isopropyl8,10,12,14,16-pentamethyl-3,7,17-trioxo-1,4,8-triazacycloheptadec-5yl]methyl]phenyl]-2-[(2-

fluorophenyl)methylcarbamoylamino]propanamide (53)

Starting from 2-fluorobenzyl isocyanate $(0.0087 \mathrm{~mL}, 0.078 \mathrm{mmol})$ and $\mathbf{E - 1 \mathbf { b }}$ (85 mg, $0.078 \mathrm{mmol}$ ) title product ( $15.89 \mathrm{mg}$, yield $17 \%$, purity $99.5 \%$ ) was obtained by prep HPLC purification. ES $\mathrm{m} / \mathrm{z} 1197.76[\mathrm{M}+\mathrm{H}]^{+}$. Two sets of signals in the NMR (most likely conformers). ${ }^{1} \mathrm{H}$ NMR (600 MHz, DMSO-d 6 ) $\delta / \mathrm{ppm} 10(\mathrm{~s}, 1 \mathrm{H}), 9.97(\mathrm{~s}, 1 \mathrm{H}), 8.11(\mathrm{br} \mathrm{d}, J=8.4 \mathrm{~Hz}, 2 \mathrm{H}), 7.91(\mathrm{br} \mathrm{d}, J=1.7 \mathrm{~Hz}$, $2 \mathrm{H}), 7.45(\mathrm{~d}, J=8.4 \mathrm{~Hz}, 2 \mathrm{H}), 7.43-7.38(\mathrm{~m}, 4 \mathrm{H}), 7.34-7.26(\mathrm{~m}, 5 \mathrm{H}), 7.26-7.19$ $(\mathrm{m}, 6 \mathrm{H}), 7.16-7.1(\mathrm{~m}, 7 \mathrm{H}), 6.62-6.59(\mathrm{~m}, 2 \mathrm{H}), 6.41(\mathrm{~d}, J=8.9 \mathrm{~Hz}, 2 \mathrm{H}), 4.8(\mathrm{br}$ $\mathrm{d}, J=4.4 \mathrm{~Hz}, 1 \mathrm{H}), 4.70-4.65(\mathrm{~m}, 2 \mathrm{H}), 4.64(\mathrm{br} \mathrm{d}, J=2 \mathrm{~Hz}, 1 \mathrm{H}), 4.45(\mathrm{~d}, J=7.2$ $\mathrm{Hz}, 1 \mathrm{H}), 4.37$ (d, $J=7.2 \mathrm{~Hz}, 1 \mathrm{H}), 4.29(\mathrm{~d}, J=7.7 \mathrm{~Hz}, 2 \mathrm{H}), 4.27-4.25(\mathrm{~m}, 1 \mathrm{H})$, $4.25-4.21(\mathrm{~m}, 4 \mathrm{H}), 4.2(\mathrm{br} \mathrm{d}, J=6.2 \mathrm{~Hz}, 1 \mathrm{H}), 4.13(\mathrm{br} \mathrm{s}, 2 \mathrm{H}), 4.10-4.01(\mathrm{~m}, 5 \mathrm{H}), 3.98(\mathrm{br} \mathrm{d}, J=10.5 \mathrm{~Hz}, 1 \mathrm{H}), 3.89(\mathrm{br} \mathrm{d}, J=0.7$ $\mathrm{Hz}, 1 \mathrm{H}), 3.84(\mathrm{br} \mathrm{d}, J=8.1 \mathrm{~Hz}, 1 \mathrm{H}), 3.7(\mathrm{~s}, 1 \mathrm{H}), 3.69-3.66(\mathrm{~m}, 1 \mathrm{H}), 3.59(\mathrm{br} \mathrm{d}, J=12.5 \mathrm{~Hz}, 1 \mathrm{H}), 3.52(\mathrm{br} \mathrm{d}, J=7 \mathrm{~Hz}, 2 \mathrm{H}), 3.46(\mathrm{br}$ $\mathrm{d}, J=5.1 \mathrm{~Hz}, 1 \mathrm{H}), 3.21(\mathrm{~s}, 4 \mathrm{H}), 3.19(\mathrm{~s}, 2 \mathrm{H}), 3.13-3.01(\mathrm{~m}, 7 \mathrm{H}), 2.98(\mathrm{br} \mathrm{d}, J=10.3 \mathrm{~Hz}, 1 \mathrm{H}), 2.93-2.86(\mathrm{~m}, 4 \mathrm{H}), 2.82-2.76(\mathrm{~m}$, $4 \mathrm{H}), 2.73-2.68(\mathrm{~m}, 1 \mathrm{H}), 2.64-2.56(\mathrm{~m}, 5 \mathrm{H}), 2.50-2.35(\mathrm{~m}, 6 \mathrm{H}), 2.27(\mathrm{br} \mathrm{d}, J=14.7 \mathrm{~Hz}, 1 \mathrm{H}), 2.25-2.22(\mathrm{~m}, 12 \mathrm{H}), 2.11(\mathrm{br} \mathrm{s}, 1 \mathrm{H})$, 2.01-1.94 (m, 2H), 1.80-1.74 (m, 1H), $1.61(\mathrm{br} \mathrm{d}, J=7.2 \mathrm{~Hz}, 2 \mathrm{H}), 1.51-1.39(\mathrm{~m}, 4 \mathrm{H}), 1.25(\mathrm{br} \mathrm{d}, J=8.1 \mathrm{~Hz}, 2 \mathrm{H}), 1.2(\mathrm{~s}, 3 \mathrm{H}), 1.18-$ $1.15(\mathrm{~m}, 8 \mathrm{H}), 1.15-1.12(\mathrm{~m}, 10 \mathrm{H}), 1.12-1.1(\mathrm{~m}, 5 \mathrm{H}), 1.09(\mathrm{~d}, J=6.1 \mathrm{~Hz}, 6 \mathrm{H}), 0.99(\mathrm{br} \mathrm{d}, J=7.3 \mathrm{~Hz}, 6 \mathrm{H}), 0.96-0.88(\mathrm{~m}, 6 \mathrm{H}), 0.69$ $(\mathrm{d}, J=6.8 \mathrm{~Hz}, 3 \mathrm{H}), 0.63(\mathrm{br} \mathrm{d}, J=6.8 \mathrm{~Hz}, 3 \mathrm{H}), 0.58(\mathrm{~d}, J=6.8 \mathrm{~Hz}, 3 \mathrm{H}), 0.51(\mathrm{~d}, J=6.8 \mathrm{~Hz}, 3 \mathrm{H})$. 


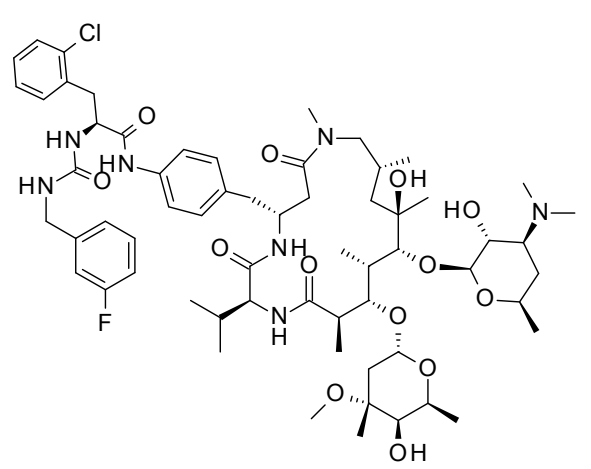

(2S)-3-(2-chlorophenyl)- $N$-[4-[[(2S,5R,10R,12R,13R,14S,15S,16R)-13-( $\beta$-Ddesosaminyl)oxy-12-hydroxy-15-( $\alpha$-L-cladinosyl)oxy-2-isopropyl-

8,10,12,14,16-pentamethyl-3,7,17-trioxo-1,4,8-triazacycloheptadec-5yl]methyl]phenyl]-2-[(3-

fluorophenyl)methylcarbamoylamino]propanamide (54)

Starting from 3-fluorobenzyl isocyanate $(0.0076 \mathrm{~mL}, 0.059 \mathrm{mmol})$ and $\mathbf{E - 1 b}$ ( $62.5 \mathrm{mg}, 0.059 \mathrm{mmol}$ ) title product ( $13.13 \mathrm{mg}$, yield $18 \%$, purity $95 \%$ ) was obtained by prep HPLC purification. $\mathrm{ES}^{+} \mathrm{m} / \mathrm{z} 1196.86[\mathrm{M}+\mathrm{H}]^{+}$. Two sets of signals in the NMR (most likely conformers). ${ }^{1} \mathrm{H}$ NMR (500 MHz, DMSO- $\mathrm{d}_{6}$ ) $\delta /$ ppm $10(\mathrm{br} \mathrm{s}, 1 \mathrm{H}), 9.98(\mathrm{~s}, 1 \mathrm{H}), 8.27-8.26(\mathrm{~m}, 2 \mathrm{H}), 8.13(\mathrm{br} \mathrm{d}, J=10.7 \mathrm{~Hz}$, $2 \mathrm{H}), 7.93$ (br s, 4H), 7.45-7.37 (m, 5H), $7.34(\mathrm{br} \mathrm{d}, J=5.5 \mathrm{~Hz}, 2 \mathrm{H}), 7.27-7.19$ (m, 5H), 7.14-7.09 (m, 7H), 6.97 (s, 1H), 6.71-6.66 (m, 3H), 6.37 (br s, 1H), $4.76(\mathrm{~d}, J=4.6 \mathrm{~Hz}, 2 \mathrm{H}), 4.68(\mathrm{br} \mathrm{s}, 2 \mathrm{H}), 4.47-4.42(\mathrm{~m}, 3 \mathrm{H}), 4.36(\mathrm{~s}, 3 \mathrm{H}), 4.3(\mathrm{br}$ s, 3H), 4.25-4.22 (m, 4H), 4.19 (dd, $J=9.3,6.3 \mathrm{~Hz}, 2 \mathrm{H}), 4.16-4.14(\mathrm{~m}, 5 \mathrm{H}), 4.11-4.07(\mathrm{~m}, 5 \mathrm{H}), 4.06$ (br s, 3H), $3.93(\mathrm{br} \mathrm{s}, 3 \mathrm{H})$, 3.75 (br s, 3H), 3.21-3.16 (m, 3H), 3.13-3 (m, 3H), 2.99-2.84 (m, 4H), 2.77 (s, 4H), 2.62-2.55 (m, 5H), 2.48-2.41 (m, 4H), 2.30$2.23(\mathrm{~m}, 12 \mathrm{H}), 2.21(\mathrm{~s}, 3 \mathrm{H}), 2.11-2.05(\mathrm{~m}, 2 \mathrm{H}), 2.02-1.92(\mathrm{~m}, 3 \mathrm{H}), 1.77-1.69(\mathrm{~m}, 2 \mathrm{H}), 1.65-1.57(\mathrm{~m}, 3 \mathrm{H}), 1.51-1.35(\mathrm{~m}, 3 \mathrm{H})$, $1.24(\mathrm{br} \mathrm{s}, 3 \mathrm{H}), 1.19-1.05(\mathrm{~m}, 29 \mathrm{H}), 0.97(\mathrm{br} \mathrm{d}, J=7.3 \mathrm{~Hz}, 5 \mathrm{H}), 0.93-0.88(\mathrm{~m}, 6 \mathrm{H}), 0.69-0.65(\mathrm{~m}, 3 \mathrm{H}), 0.61(\mathrm{~d}, J=6.4 \mathrm{~Hz}, 3 \mathrm{H})$, $0.57(\mathrm{~d}, J=6.7 \mathrm{~Hz}, 3 \mathrm{H}), 0.47(\mathrm{~d}, J=6.7 \mathrm{~Hz}, 3 \mathrm{H})$.

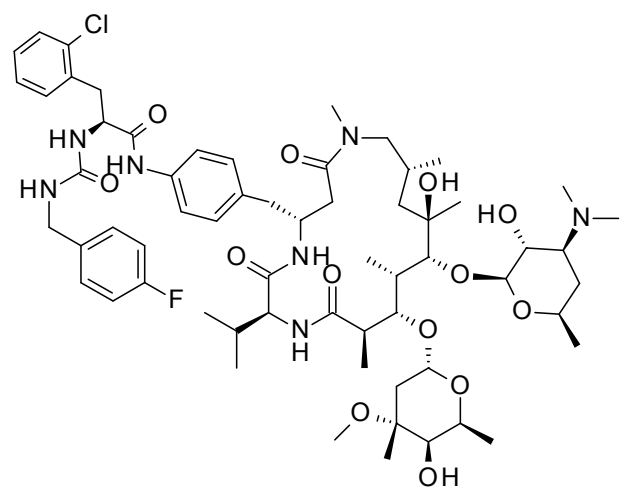

(2S)-3-(2-chlorophenyl)- $N$-[4-[[(2S,5R,10R,12R,13R,14S,15S,16R)-13-( $\beta$-Ddesosaminyl)oxy-12-hydroxy-15-( $\alpha$-L-cladinosyl)oxy-2-isopropyl8,10,12,14,16-pentamethyl-3,7,17-trioxo-1,4,8-triazacycloheptadec-5yl]methyl]phenyl]-2-[(4fluorophenyl)methylcarbamoylamino]propenamide (55)

Starting from 3-fluorobenzyl isocyanate $(0.0087 \mathrm{~mL}, 0.078 \mathrm{mmol})$ and $\mathbf{E - 1 \mathbf { b }}$ ( $85 \mathrm{mg}, 0.078 \mathrm{mmol}$ ) title product ( $25.58 \mathrm{mg}$, yield $26 \%$, purity $94.4 \%$ ) was obtained by prep HPLC purification. $\mathrm{ES}^{+} \mathrm{m} / \mathrm{z} 1196.8[\mathrm{M}+\mathrm{H}]^{+}$. Two sets of signals in the NMR (most likely conformers). ${ }^{1} \mathrm{H}$ NMR (500 MHz, DMSO- $\mathrm{d}_{6}$ ) $\delta / \mathrm{ppm} 10.01(\mathrm{~s}, 1 \mathrm{H}), 9.98(\mathrm{~s}, 1 \mathrm{H}), 8.11(\mathrm{br} \mathrm{d}, J=8.9 \mathrm{~Hz}, 2 \mathrm{H}), 7.9$ (br d, $J=9.5$ $\mathrm{Hz}, 2 \mathrm{H}), 7.46(\mathrm{~d}, J=8.5 \mathrm{~Hz}, 2 \mathrm{H}), 7.44-7.4(\mathrm{~m}, 3 \mathrm{H}), 7.39(\mathrm{~d}, J=2.4 \mathrm{~Hz}, 2 \mathrm{H}), 7.34-$ $7.3(\mathrm{~m}, 2 \mathrm{H}), 7.28(\mathrm{br} \mathrm{d}, J=8.5 \mathrm{~Hz}, 2 \mathrm{H}), 7.27-7.18(\mathrm{~m}, 8 \mathrm{H}), 7.16-7.08(\mathrm{~m}, 7 \mathrm{H})$, $6.62(\mathrm{brt}, J=6 \mathrm{~Hz}, 2 \mathrm{H}), 6.37(\mathrm{~d}, J=8.2 \mathrm{~Hz}, 2 \mathrm{H}), 4.8(\mathrm{br} \mathrm{d}, J=4.6 \mathrm{~Hz}, 2 \mathrm{H}), 4.72-$ $4.65(\mathrm{~m}, 2 \mathrm{H}), 4.63(\mathrm{br} \mathrm{d}, J=4.9 \mathrm{~Hz}, 2 \mathrm{H}), 4.45(\mathrm{~d}, J=7 \mathrm{~Hz}, 2 \mathrm{H}), 4.37(\mathrm{~d}, J=7.3$ $\mathrm{Hz}, 2 \mathrm{H}), 4.29(\mathrm{~d}, J=7.6 \mathrm{~Hz}, 2 \mathrm{H}), 4.23(\mathrm{~d}, J=8.2 \mathrm{~Hz}, 2 \mathrm{H}), 4.2(\mathrm{br} \mathrm{d}, J=6.1 \mathrm{~Hz}, 2 \mathrm{H}), 4.19-4.11(\mathrm{~m}, 5 \mathrm{H}), 4.08-4(\mathrm{~m}, 4 \mathrm{H}), 4-3.94(\mathrm{~m}$, $1 \mathrm{H}), 3.89(\mathrm{~s}, 1 \mathrm{H}), 3.84(\mathrm{br} \mathrm{d}, J=7.6 \mathrm{~Hz}, 1 \mathrm{H}), 3.7(\mathrm{~s}, 1 \mathrm{H}), 3.67(\mathrm{br} \mathrm{dd}, J=9.8,6.7 \mathrm{~Hz}, 1 \mathrm{H}), 3.62-3.57(\mathrm{~m}, 1 \mathrm{H}), 3.52(\mathrm{br} \mathrm{d}, J=6.7$ $\mathrm{Hz}, 2 \mathrm{H}), 3.48-3.43(\mathrm{~m}, 1 \mathrm{H}), 3.21(\mathrm{~s}, 4 \mathrm{H}), 3.19(\mathrm{~s}, 2 \mathrm{H}), 3.12(\mathrm{br} \mathrm{d}, J=6.4 \mathrm{~Hz}, 1 \mathrm{H}), 3.10-3.07(\mathrm{~m}, 2 \mathrm{H}), 3.06-3.01(\mathrm{~m}, 3 \mathrm{H}), 3-2.95$ (m, 1H), 2.94-2.85 (m, 4H), 2.82-2.74 (m, 4H), 2.73-2.67 (m, 1H), 2.66-2.63 (m, 1H), 2.62-2.56 (m, 3H), 2.48-2.44 (m, 2H), 2.44-2.39 (m, 1H), 2.38-2.34 (m, 2H), 2.29-2.17 (m, 13H), 2.09 (br s, 2H), 1.98 (dt, $J=13.4,6.7 \mathrm{~Hz}, 3 \mathrm{H}), 1.77$ (dq, $J=13.8,6.8$ $\mathrm{Hz}, 1 \mathrm{H}), 1.6(\mathrm{br} \mathrm{d}, J=7 \mathrm{~Hz}, 2 \mathrm{H}), 1.55-1.37(\mathrm{~m}, 3 \mathrm{H}), 1.32-1.22(\mathrm{~m}, 3 \mathrm{H}), 1.21-1.06(\mathrm{~m}, 30 \mathrm{H}), 0.99(\mathrm{br} \mathrm{d}, J=7.3 \mathrm{~Hz}, 6 \mathrm{H}), 0.96-$ $0.88(\mathrm{~m}, 6 \mathrm{H}), 0.69(\mathrm{~d}, J=6.7 \mathrm{~Hz}, 3 \mathrm{H}), 0.63(\mathrm{br} \mathrm{d}, J=6.7 \mathrm{~Hz}, 3 \mathrm{H}), 0.58(\mathrm{~d}, J=6.7 \mathrm{~Hz}, 3 \mathrm{H}), 0.51(\mathrm{~d}, J=6.7 \mathrm{~Hz}, 3 \mathrm{H})$.

\section{General procedure for compounds 56-63}

Corresponding acid (1.1 eq) in dry DCM was activated with HATU (1.2 eq), HOAt (1.2 eq) and TMP (2.5 eq) for 15 min. Then solution of E-1b-E-1g (1 eq) in DCM was added and reaction mixture was stirred for $1 \mathrm{~h}$ at room temperature. Sat. NaHCO3 was added, layers were separated, and organic layer was dried over anhydrous sodium sulfate, filtered and evaporated to dryness to get crude material. Crude was purified by column chromatography using DCM:MeOH: $\mathrm{NH}_{4} \mathrm{OH}=10: 1: 0.1$ as eluent or by prep HPLC purification (extended A, high pH) or by column chromatography using DCM:MeOH: $\mathrm{NH}_{4} \mathrm{OH}=10: 1: 0.1$ as eluent to get title product.to get title compound.

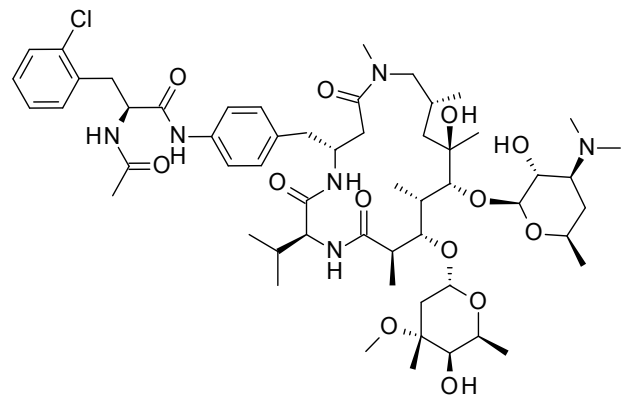

(2S)-2-acetamido-3-(2-chlorophenyl)- $N$-[4-

$[[(2 S, 5 R, 10 R, 12 R, 13 R, 14 S, 15 S, 16 R)$-13-( $\beta$-D-desosaminyl)oxy-12-hydroxy-

15 -( $\alpha$-L-cladinosyl)oxy-2-isopropyl-8,10,12,14,16-pentamethyl-3,7,17-

trioxo-1,4,8-triazacycloheptadec-5-yl]methyl]phenyl]propanamide (56)

Starting from acetic acid $(0.0038 \mathrm{~mL}, 0.067 \mathrm{mmol})$ and E-1b $(70 \mathrm{mg}, 0.067$ mmol) title product (31 mg, yield $43 \%$, purity $98.2 \%$ ) was obtained by prep HPLC purification. ES $\mathrm{m} / \mathrm{z} 1087.63[\mathrm{M}+\mathrm{H}]^{+} .{ }^{1} \mathrm{H}$ NMR $\left(500 \mathrm{MHz}, \mathrm{DMSO}-\mathrm{d}_{6}\right)$ $\delta /$ ppm $9.93(\mathrm{~s}, 1 \mathrm{H}), 9.89(\mathrm{~s}, 1 \mathrm{H}), 8.28(\mathrm{br} \mathrm{d}, J=8.2 \mathrm{~Hz}, 1 \mathrm{H}), 8.27$ (br d, $J=8.2$ $\mathrm{Hz}, 1 \mathrm{H}$ ), 8.09 (br d, $J=8.5 \mathrm{~Hz}, 1 \mathrm{H}$ ), 7.89 (br d, $J=8.9 \mathrm{~Hz}, 1 \mathrm{H}$ ), 7.44 (br d, $J=8.5$ $\mathrm{Hz}, 2 \mathrm{H}), 7.42-7.4(\mathrm{~m}, 2 \mathrm{H}), 7.40-7.38(\mathrm{~m}, 2 \mathrm{H}), 7.33-7.29(\mathrm{~m}, 2 \mathrm{H}), 7.27$ (br d, J $=8.5 \mathrm{~Hz}, 2 \mathrm{H}), 7.24-7.22(\mathrm{~m}, 2 \mathrm{H}), 7.21(\mathrm{~s}, 2 \mathrm{H}), 7.1(\mathrm{br} \mathrm{d}, J=8.5 \mathrm{~Hz}, 2 \mathrm{H}), 7.10-$ $7.07(\mathrm{~m}, 2 \mathrm{H}), 4.78(\mathrm{br} \mathrm{d}, J=4.9 \mathrm{~Hz}, 1 \mathrm{H}), 4.76-4.7(\mathrm{~m}, 2 \mathrm{H}), 4.62(\mathrm{br} \mathrm{d}, J=4.3 \mathrm{~Hz}, 1 \mathrm{H}), 4.44(\mathrm{~d}, J=7.3 \mathrm{~Hz}, 1 \mathrm{H}), 4.36(\mathrm{br} \mathrm{d}, J=7.3$ $\mathrm{Hz}, 1 \mathrm{H}), 4.28$ (d, J = 7.6 Hz, 1H), 4.26-4.24 (m, 1H), 4.21 (d, $J=8.2 \mathrm{~Hz}, 1 \mathrm{H}), 4.16-4.11(\mathrm{~m}, 1 \mathrm{H}), 4.10-4.08(\mathrm{~m}, 1 \mathrm{H}), 4.08-4.03$ 
(m, 2H), 4.03-3.99 (m, 1H), 3.96 (br t, $J=7.5 \mathrm{~Hz}, 1 \mathrm{H}), 3.82$ (br d, $J=7.6 \mathrm{~Hz}, 1 \mathrm{H}), 3.66$ (br dd, $J=10.2,6.6 \mathrm{~Hz}, 1 \mathrm{H}$ ), 3.62-3.57 (m, 1H), 3.5 (br d, $J=6.7 \mathrm{~Hz}, 1 \mathrm{H}), 3.45$ (br d, $J=5.5 \mathrm{~Hz}, 1 \mathrm{H}), 3.26-3.22(\mathrm{~m}, 2 \mathrm{H}), 3.2(\mathrm{~s}, 3 \mathrm{H}), 3.17$ (s, $3 \mathrm{H}), 3.13(\mathrm{br} \mathrm{dd}, J=14.2$, $6.3 \mathrm{~Hz}, 2 \mathrm{H}), 3.10-3.04(\mathrm{~m}, 2 \mathrm{H}), 3.04-3.02(\mathrm{~m}, 1 \mathrm{H}), 2.98(\mathrm{br} \mathrm{dd}, J=14.2,8.4 \mathrm{~Hz}, 2 \mathrm{H}), 2.91(\mathrm{br} \mathrm{d}, J=8.9 \mathrm{~Hz}, 2 \mathrm{H}), 2.88(\mathrm{~s}, 3 \mathrm{H})$, $2.78(\mathrm{~s}, 3 \mathrm{H}), 2.72-2.54(\mathrm{~m}, 6 \mathrm{H}), 2.47-2.42(\mathrm{~m}, 2 \mathrm{H}), 2.41-2.32(\mathrm{~m}, 4 \mathrm{H}), 2.29-2.23(\mathrm{~m}, 2 \mathrm{H}), 2.23(\mathrm{~s}, 12 \mathrm{H}), 2.13-2.1(\mathrm{~m}, 1 \mathrm{H})$, 2.09-2.06 (m, 1H), 2.02-1.98 (m, 2H), 1.97-1.91 (m, 1H), $1.81(\mathrm{~s}, 6 \mathrm{H}), 1.78-1.72(\mathrm{~m}, 1 \mathrm{H}), 1.64-1.56(\mathrm{~m}, 2 \mathrm{H}), 1.51-1.43(\mathrm{~m}$, $1 \mathrm{H}), 1.42-1.35(\mathrm{~m}, 1 \mathrm{H}), 1.26-1.21(\mathrm{~m}, 4 \mathrm{H}), 1.19(\mathrm{~s}, 3 \mathrm{H}), 1.15(\mathrm{~s}, 3 \mathrm{H}), 1.17-1.14(\mathrm{~m}, 3 \mathrm{H}), 1.13-1.1(\mathrm{~m}, 18 \mathrm{H}), 1.10-1.09(\mathrm{~m}, 2 \mathrm{H})$, 1.08 (br d, $J=5.8 \mathrm{~Hz}, 3 \mathrm{H}), 0.98$ (br d, $J=7.3 \mathrm{~Hz}, 6 \mathrm{H}), 0.92(\mathrm{br} \mathrm{d}, J=6.4 \mathrm{~Hz}, 3 \mathrm{H}), 0.9(\mathrm{br} \mathrm{d}, J=6.7 \mathrm{~Hz}, 3 \mathrm{H}), 0.68(\mathrm{br} \mathrm{d}, J=6.7 \mathrm{~Hz}$, $3 \mathrm{H}), 0.62(\mathrm{br} \mathrm{d}, J=6.7 \mathrm{~Hz}, 3 \mathrm{H}), 0.57(\mathrm{brd}, J=6.7 \mathrm{~Hz}, 3 \mathrm{H}), 0.5(\mathrm{br} \mathrm{d}, J=6.7 \mathrm{~Hz}, 3 \mathrm{H})$.

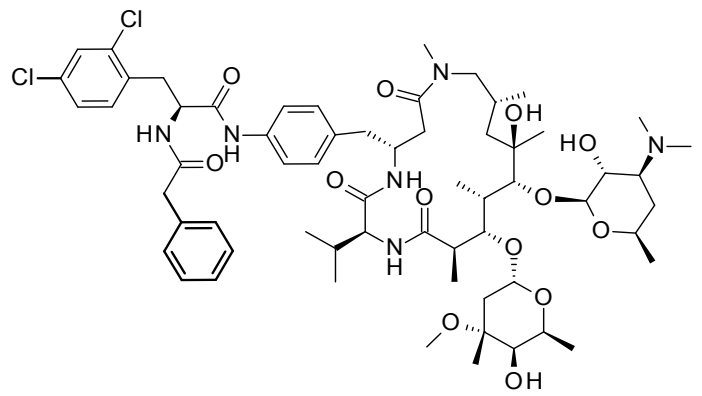

(2S)-3-(2,4-dichlorophenyl)- $N$-[4-[[(2S,5R,10R,12R,13R,14S,15S,16R)13- $\quad(\beta$-D-desosaminyl)oxy-12-hydroxy-15-( $\alpha$-L-cladinosyl)oxy-2isopropyl-8,10,12,14,16-pentamethyl-3,7,17-trioxo-1,4,8triazacycloheptadec-5-yl]methyl]phenyl]-2-[(2phenylacetyl)amino]propanamide (57) Starting from phenylacetic acid (10.71 $\mathrm{mg}, 0.078 \mathrm{mmol}$ ) and E-1c (85 $\mathrm{mg}, 0.078 \mathrm{mmol}$ ) title product (21 mg, yield $22 \%$, purity $98 \%$ ) was obtained by prep HPLC purification. ES ${ }^{+} \mathrm{m} / \mathrm{z} 1197.8[\mathrm{M}+\mathrm{H}]^{+}$. Two sets of signals in the NMR (most likely conformers). ${ }^{1} \mathrm{H}$ NMR $(500 \mathrm{MHz}$, DMSO$\left.\mathrm{d}_{6}\right) \delta / \mathrm{ppm} 9.99(\mathrm{~s}, 1 \mathrm{H}), 9.96(\mathrm{~s}, 1 \mathrm{H}), 8.50-8.45(\mathrm{~m}, 3 \mathrm{H}), 8.11(\mathrm{br} \mathrm{d}, J=8.9$ $\mathrm{Hz}, 2 \mathrm{H}), 7.93-7.87(\mathrm{~m}, 1 \mathrm{H}), 7.5(\mathrm{~d}, J=2.1 \mathrm{~Hz}, 2 \mathrm{H}), 7.53-7.49(\mathrm{~m}, 1 \mathrm{H})$, 7.45-7.35 (m, 4H), 7.29-7.17 (m, 11H), 7.15-7.08 (m, 8H), 4.78-4.72 (m, 3H), $4.61(\mathrm{~d}, J=4.3 \mathrm{~Hz}, 2 \mathrm{H}), 4.44(\mathrm{~d}, J=7.3 \mathrm{~Hz}, 2 \mathrm{H})$, 4.39-4.35 (m, 2H), $4.3(\mathrm{~d}, J=8.2 \mathrm{~Hz}, 2 \mathrm{H}), 4.28-4.22(\mathrm{~m}, 2 \mathrm{H}), 4.18-4.1(\mathrm{~m}, 4 \mathrm{H}), 4.08-3.92(\mathrm{~m}, 6 \mathrm{H}), 3.75(\mathrm{~s}, 2 \mathrm{H}), 3.77(\mathrm{br} \mathrm{s}, 2 \mathrm{H})$, $3.45-3.39(\mathrm{~m}, 12 \mathrm{H}), 3.2(\mathrm{~s}, 4 \mathrm{H}), 3.17(\mathrm{~s}, 1 \mathrm{H}), 3.16-3.1(\mathrm{~m}, 4 \mathrm{H}), 3.10-3.04(\mathrm{~m}, 2 \mathrm{H}), 3(\mathrm{br} d \mathrm{~d}, J=14.0,8.5 \mathrm{~Hz}, 3 \mathrm{H}), 2.94-2.84(\mathrm{~m}$, $5 \mathrm{H}), 2.77(\mathrm{~s}, 3 \mathrm{H}), 2.62-2.56(\mathrm{~m}, 4 \mathrm{H}), 2.24(\mathrm{~s}, 11 \mathrm{H}), 2-1.93(\mathrm{~m}, 2 \mathrm{H}), 1.76-1.68(\mathrm{~m}, 1 \mathrm{H}), 1.65-1.58(\mathrm{~m}, 2 \mathrm{H}), 1.52-1.36(\mathrm{~m}, 2 \mathrm{H})$, $1.24-1.21(\mathrm{~m}, 3 \mathrm{H}), 1.18(\mathrm{~s}, 2 \mathrm{H}), 1.17-1.06(\mathrm{~m}, 34 \mathrm{H}), 0.98(\mathrm{br} \mathrm{d}, J=7.3 \mathrm{~Hz}, 5 \mathrm{H}), 0.89(\mathrm{~d}, J=6.7 \mathrm{~Hz}, 3 \mathrm{H}), 0.66(\mathrm{~d}, J=6.7 \mathrm{~Hz}, 3 \mathrm{H})$, $0.61(\mathrm{br} \mathrm{d}, J=6.7 \mathrm{~Hz}, 3 \mathrm{H}), 0.56(\mathrm{~d}, J=6.7 \mathrm{~Hz}, 3 \mathrm{H}), 0.46(\mathrm{~d}, J=6.7 \mathrm{~Hz}, 3 \mathrm{H})$.

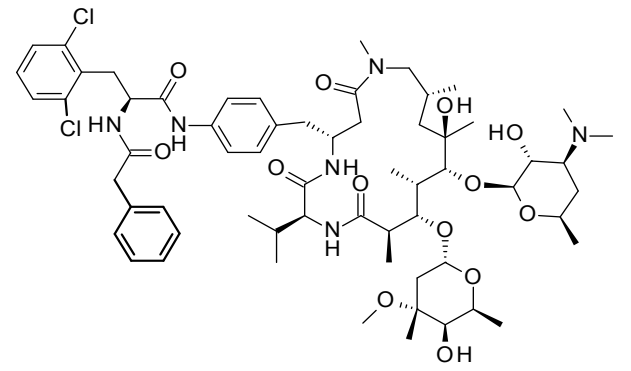

(2S)-3-(2,6-dichlorophenyl)- $N$-[4-[[(2S,5R,10R,12R,13R,14S,15S,16R)-13-( $\beta$ D-desosaminyl)oxy-12-hydroxy-15-( $\alpha$-L-cladinosyl)oxy-2-isopropyl8,10,12,14,16-pentamethyl-3,7,17-trioxo-1,4,8-triazacycloheptadec-5yl]methyl]phenyl]-2-[(2-phenylacetyl)amino]propanamide (58)

Starting from phenylacetic acid (10.71 mg, $0.078 \mathrm{mmol}$ ) and E-1d (85 mg, $0.078 \mathrm{mmol}$ ) title product (28 mg, yield $30 \%$, purity $97.55 \%$ ) was obtained by prep HPLC purification. $\mathrm{ES}^{+} \mathrm{m} / \mathrm{z} 1197.7[\mathrm{M}+\mathrm{H}]^{+}$. Two sets of signals in the NMR (most likely conformers). ${ }^{1} \mathrm{H}$ NMR (500 MHz, DMSO-d $\left.\mathrm{d}_{6}\right) \delta 10(\mathrm{~s}, 1 \mathrm{H}), 9.95$ (s, 1H), 8.50-8.44 (m, 3H), 8.13-8.08 (m, 1H), 7.93 (br s, 1H), 7.53-7.49 (m, $3 \mathrm{H}), 7.44-7.37(\mathrm{~m}, 5 \mathrm{H}), 7.28-7.19(\mathrm{~m}, 6 \mathrm{H}), 7.14-7.1(\mathrm{~m}, 12 \mathrm{H}), 4.71(\mathrm{br} \mathrm{d}, J=$ $0.9 \mathrm{~Hz}, 3 \mathrm{H}), 4.62-4.59(\mathrm{~m}, 2 \mathrm{H}), 4.44(\mathrm{~d}, J=7 \mathrm{~Hz}, 2 \mathrm{H}), 4.37(\mathrm{t}, J=6.4 \mathrm{~Hz}, 2 \mathrm{H}), 4.09(\mathrm{~s}, 2 \mathrm{H}), 4.07-4.01(\mathrm{~m}, 4 \mathrm{H}), 4.01-3.92(\mathrm{~m}, 1 \mathrm{H})$, 3.75 (br s, 3H), 3.48-3.38 (m, 51H), 3.20-3.15 (m, 15H), 3.10-3.05 (m, 3H), 3.03-2.97 (m, 2H), 2.87 (s, $4 \mathrm{H}), 2.77$ (s, $7 \mathrm{H}), 2.60-$ $2.56(\mathrm{~m}, 4 \mathrm{H}), 2.28-2.24(\mathrm{~m}, 2 \mathrm{H}), 2.21(\mathrm{~s}, 24 \mathrm{H}), 2-1.94(\mathrm{~m}, 3 \mathrm{H}), 1.75-1.7(\mathrm{~m}, 1 \mathrm{H}), 1.64-1.57(\mathrm{~m}, 2 \mathrm{H}), 1.51-1.36(\mathrm{~m}, 1 \mathrm{H}), 1.22$ (br d, $J=4.6 \mathrm{~Hz}, 4 \mathrm{H}), 1.18(\mathrm{~s}, 4 \mathrm{H}), 1.16-1.06(\mathrm{~m}, 62 \mathrm{H}), 0.97(\mathrm{br} \mathrm{d}, J=7.3 \mathrm{~Hz}, 9 \mathrm{H}), 0.93-0.88(\mathrm{~m}, 10 \mathrm{H}), 0.66(\mathrm{~d}, J=6.7 \mathrm{~Hz}, 3 \mathrm{H})$, $0.61(\mathrm{~d}, J=7 \mathrm{~Hz}, 3 \mathrm{H}), 0.56(\mathrm{~d}, J=6.7 \mathrm{~Hz}, 3 \mathrm{H}), 0.46(\mathrm{~d}, J=6.7 \mathrm{~Hz}, 3 \mathrm{H})$.

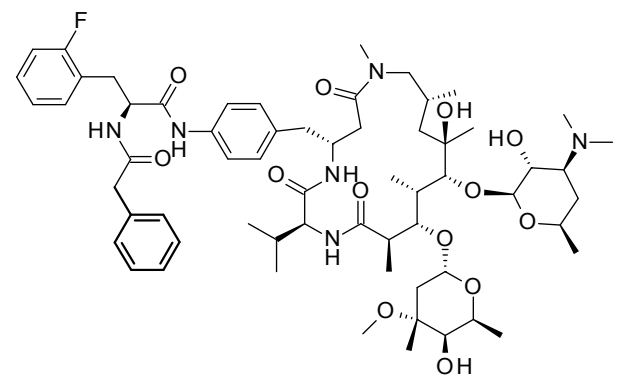

$(2 S)-N$-[4-[[(2S,5R,10R,12R,13R,14S,15S,16R)-13-( $\beta$-D-desosaminyl)oxy12-hydroxy-15-( $\alpha$-L-cladinosyl)oxy-2-isopropyl-8,10,12,14,16-pentamethyl3,7,17-trioxo-1,4,8-triazacycloheptadec-5-yl]methyl]phenyl]-3-[2-

fluorophenyl)-2-[(2-phenylacetyl)amino]propanamide (59)

Starting from phenylacetic acid $(9.3 \mathrm{mg}, 0.068 \mathrm{mmol})$ and E-1e $(66.7 \mathrm{mg}$, $0.065 \mathrm{mmol}$ ) title product (40 mg, yield $54 \%$, purity $94.49 \%$ ) was obtained using column chromatography for purification. $\mathrm{ES}^{+} \mathrm{m} / \mathrm{z} 1147.5[\mathrm{M}+\mathrm{H}]^{+}$. Two sets of signals in the NMR (most likely conformers). ${ }^{1} \mathrm{H}$ NMR (500 MHz, DMSO$\left.\mathrm{d}_{6}\right) \delta / \mathrm{ppm} 10(\mathrm{~s}, 1 \mathrm{H}), 9.97(\mathrm{~s}, 1 \mathrm{H}), 8.45-8.4(\mathrm{~m}, 3 \mathrm{H}), 8.13(\mathrm{br} \mathrm{d}, J=8.2 \mathrm{~Hz}, 2 \mathrm{H})$, 7.91 (br d, $J=8.9 \mathrm{~Hz}, 2 \mathrm{H}), 7.43-7.37(\mathrm{~m}, 3 \mathrm{H}), 7.31-7.27(\mathrm{~m}, 1 \mathrm{H}), 7.26-7.2(\mathrm{~m}$, 7H), 7.20-7.16 (m, 2H), 7.14-7.01 (m, 10H), $4.81(\mathrm{br} \mathrm{d}, J=4.3 \mathrm{~Hz}, 2 \mathrm{H}), 4.77-$ $4.69(\mathrm{~m}, 2 \mathrm{H}), 4.66$ (br d, $J=4 \mathrm{~Hz}, 2 \mathrm{H}), 4.47$ (br d, $J=7 \mathrm{~Hz}, 2 \mathrm{H}), 4.4$ (br d, $J=7 \mathrm{~Hz}, 2 \mathrm{H}), 4.31-4.19$ (m, 2H), 4.1 (br s, 1H), $4.08-$ 3.97 (m, 4H), 3.95-3.9 (m, 1H), 3.84 (br d, J = 8.2 Hz, 2H), 3.71 (br s, 1H), 3.67 (s, 1H), 3.56-3.37 (m, 8H), 3.24-3.15 (m, 7H), 3.06 (br dd, $J=13.9,6 \mathrm{~Hz}, 3 \mathrm{H}), 3.01-2.83(\mathrm{~m}, 8 \mathrm{H}), 2.8(\mathrm{~s}, 4 \mathrm{H}), 2.77-2.66(\mathrm{~m}, 2 \mathrm{H}), 2.63-2.53(\mathrm{~m}, 6 \mathrm{H}), 2.48-2.45(\mathrm{~m}, 4 \mathrm{H}), 2.40-$ $2.31(\mathrm{~m}, 4 \mathrm{H}), 2.31-2.19(\mathrm{~m}, 2 \mathrm{H}), 2.1(\mathrm{br} \mathrm{s}, 1 \mathrm{H}), 1.99(\mathrm{~s}, 2 \mathrm{H}), 1.96(\mathrm{br} \mathrm{d}, J=6.7 \mathrm{~Hz}, 2 \mathrm{H}), 1.77$ (br dd, $J=13.3,6.6 \mathrm{~Hz}, 3 \mathrm{H}), 1.70-$ $1.63(\mathrm{~m}, 1 \mathrm{H}), 1.56-1.38(\mathrm{~m}, 4 \mathrm{H}), 1.38-1.25(\mathrm{~m}, 9 \mathrm{H}), 1.21-1.08(\mathrm{~m}, 30 \mathrm{H}), 0.98(\mathrm{br} \mathrm{d}, J=7.3 \mathrm{~Hz}, 6 \mathrm{H}), 0.95-0.85(\mathrm{~m}, 6 \mathrm{H}), 0.67(\mathrm{br}$ $\mathrm{d}, J=6.4 \mathrm{~Hz}, 3 \mathrm{H}), 0.58(\mathrm{br} \mathrm{d}, J=6.4 \mathrm{~Hz}, 3 \mathrm{H}), 0.54(\mathrm{br} \mathrm{d}, J=6.7 \mathrm{~Hz}, 3 \mathrm{H}), 0.5(\mathrm{br} \mathrm{d}, J=6.7 \mathrm{~Hz}, 3 \mathrm{H})$. 


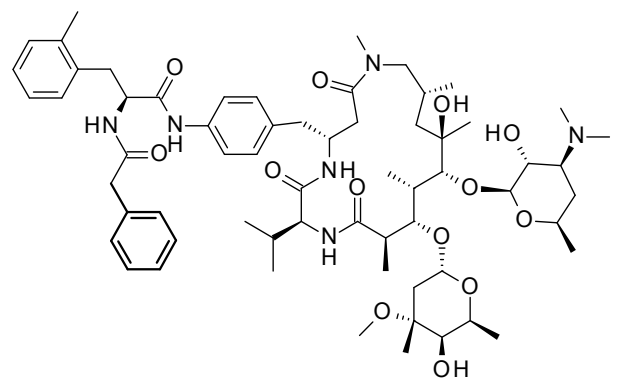

(2S)- $N$-[4-[[(2S,5R,10R,12R,13R,14S,15S,16R)-13-( $\beta$-D-desosaminyl)oxy-12hydroxy-15-( $\alpha$-L-cladinosyl)oxy-2-isopropyl-8,10,12,14,16-pentamethyl3,7,17-trioxo-1,4,8-triazacycloheptadec-5-yl]methyl]phenyl]-3-(o-tolyl)-2[(2-phenylacetyl)amino]propanamide (60)

Starting from phenylacetic acid ( $15 \mathrm{mg}, 0.112 \mathrm{mmol}$ ) and E-1f (110 mg, 0.107 mmol) title product (32 mg, yield $26 \%$, purity $99.4 \%$ ) was obtained by prep HPLC purification. $\mathrm{ES}^{+} \mathrm{m} / \mathrm{z} 1143.64[\mathrm{M}+\mathrm{H}]^{+}$. Two sets of signals in the NMR (most likely conformers). ${ }^{1} \mathrm{H}$ NMR $\left(500 \mathrm{MHz}\right.$, DMSO-d $\left.\mathrm{d}_{6}\right) \delta / \mathrm{ppm} 9.95(\mathrm{~s}, 1 \mathrm{H})$, $9.91(\mathrm{~s}, 1 \mathrm{H}), 8.50-8.45$ (m, 3H), 8.09 (br d, $J=8.5 \mathrm{~Hz}, 1 \mathrm{H}$ ), 7.89 (br d, $J=8.5$ $\mathrm{Hz}, 1 \mathrm{H}), 7.44-7.36(\mathrm{~m}, 3 \mathrm{H}), 7.29-7.2(\mathrm{~m}, 5 \mathrm{H}), 7.20-6.96(\mathrm{~m}, 15 \mathrm{H}), 4.79$ (br d, $J=4.6 \mathrm{~Hz}, 2 \mathrm{H}), 4.72-4.66(\mathrm{~m}, 2 \mathrm{H}), 4.62(\mathrm{br} \mathrm{d}, J=4.6 \mathrm{~Hz}, 2 \mathrm{H}), 4.44(\mathrm{~d}, J=7 \mathrm{~Hz}$, $2 \mathrm{H}), 4.36(\mathrm{~d}, J=7.3 \mathrm{~Hz}, 2 \mathrm{H}), 4.28(\mathrm{~d}, J=7.6 \mathrm{~Hz}, 2 \mathrm{H}), 4.25-4.14(\mathrm{~m}, 1 \mathrm{H}), 4.11(\mathrm{br} \mathrm{s}, 2 \mathrm{H}), 4.08-3.94(\mathrm{~m}, 4 \mathrm{H}), 3.88(\mathrm{~s}, 1 \mathrm{H}), 3.83$ (br d, $J=7.6 \mathrm{~Hz}, 2 \mathrm{H}), 3.69$ (s, 1H), 3.68-3.64 (m, 1H), 3.61-3.55 (m, 1H), 3.53-3.4 (m, 6H), 3.24 (br dd, $J=9.0,5.6 \mathrm{~Hz}, 2 \mathrm{H}$ ), 3.22-3.17 (m, 5H), 3.13-2.94 (m, 6H), 2.92-2.85 (m, 5H), 2.80-2.73 (m, 4H), 2.71-2.53 (m, 5H), 2.42-2.33 (m, 3H), $2.3(\mathrm{~s}, 5 \mathrm{H})$, 2.24 (s, 9H), 2.09 (br d, $J=8.5 \mathrm{~Hz}, 2 \mathrm{H}), 2.03-1.88(\mathrm{~m}, 3 \mathrm{H}), 1.76$ (dq, $J=13.7,6.8 \mathrm{~Hz}, 2 \mathrm{H}), 1.61(\mathrm{br} \mathrm{d}, J=7 \mathrm{~Hz}, 2 \mathrm{H}), 1.55-1.36$ $(\mathrm{m}, 3 \mathrm{H}), 1.28-1.21(\mathrm{~m}, 5 \mathrm{H}), 1.20-1.06(\mathrm{~m}, 27 \mathrm{H}), 0.98(\mathrm{br} \mathrm{d}, J=7.3 \mathrm{~Hz}, 5 \mathrm{H}), 0.94-0.83(\mathrm{~m}, 8 \mathrm{H}), 0.67(\mathrm{~d}, J=6.7 \mathrm{~Hz}, 3 \mathrm{H}), 0.61(\mathrm{br}$ d, $J=6.7 \mathrm{~Hz}, 3 \mathrm{H}), 0.57(\mathrm{~d}, J=6.7 \mathrm{~Hz}, 3 \mathrm{H}), 0.49(\mathrm{~d}, J=6.7 \mathrm{~Hz}, 3 \mathrm{H})$.

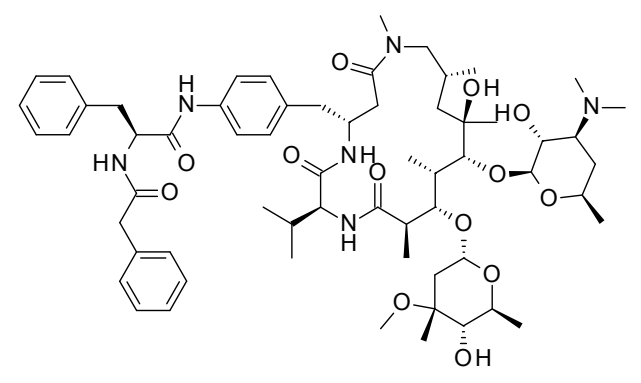

$(2 S, 5 R, 10 R, 12 R, 13 R, 14 S, 15 S, 16 R)-5-[[4-[[(2 S)-3-p h e n y l-2-[(2-$ phenylacetyl)amino]phenyl]methyl]-15-O-( $\alpha$ - $L$-cladinosyl)-13-O-( $\beta-D$ desosaminyl)-12,13,15-trihydroxy-2-isopropyl-8,10,12,14,16-pentamethyl1,4,8-triazacycloheptadecane-3,7,17-trione (61)

Starting from 2-phenylacetic acid (8.8 $\mathrm{mg}, 0.065 \mathrm{mmol})$ and E-1g $(65.3 \mathrm{mg}$, $0.065 \mathrm{mmol}$ ) title product was obtained $(60.1 \mathrm{mg}, 81.9 \%$, purity $92.47 \%$ ) as a yellowish solid foam. $\mathrm{ES}^{+} \mathrm{m} / \mathrm{z} 1129.65[\mathrm{M}+\mathrm{H}]^{+}$. Two sets of signals in the NMR (most likely conformers). ${ }^{1} \mathrm{H}$ NMR $\left(500 \mathrm{MHz}\right.$, DMSO-d $\left.\mathrm{d}_{6}\right) \delta / \mathrm{ppm} 10.05$ (s, $1 \mathrm{H}), 10.02(\mathrm{~s}, 1 \mathrm{H}), 8.48-8.45(\mathrm{~m}, 3 \mathrm{H}), 8.11(\mathrm{br} \mathrm{d}, J=8.5 \mathrm{~Hz}, 1 \mathrm{H}), 7.93-7.88(\mathrm{~m}$, $1 \mathrm{H}), 7.48-7.42(\mathrm{~m}, 3 \mathrm{H}), 7.35-7.15(\mathrm{~m}, 15 \mathrm{H}), 7.14-7.1(\mathrm{~m}, 6 \mathrm{H}), 4.8(\mathrm{br} \mathrm{d}, J=$ $4.6 \mathrm{~Hz}, 1 \mathrm{H}), 4.68(\mathrm{td}, J=8.7,5.5 \mathrm{~Hz}, 2 \mathrm{H}), 4.63(\mathrm{br} \mathrm{d}, J=4.3 \mathrm{~Hz}, 1 \mathrm{H}), 4.45(\mathrm{~d}, J=$ $7.3 \mathrm{~Hz}, 1 \mathrm{H}), 4.37(\mathrm{~d}, J=7 \mathrm{~Hz}, 1 \mathrm{H}), 4.29(\mathrm{~d}, J=7.6 \mathrm{~Hz}, 1 \mathrm{H}), 4.23(\mathrm{~d}, J=8.5 \mathrm{~Hz}, 1 \mathrm{H}), 4.17-4.08(\mathrm{~m}, 2 \mathrm{H}), 4.08-4(\mathrm{~m}, 4 \mathrm{H}), 3.98(\mathrm{br}$ $\mathrm{t}, J=7.2 \mathrm{~Hz}, 1 \mathrm{H}), 3.91-3.88(\mathrm{~m}, 1 \mathrm{H}), 3.84(\mathrm{br} \mathrm{d}, J=7.9 \mathrm{~Hz}, 1 \mathrm{H}), 3.71(\mathrm{~s}, 1 \mathrm{H}), 3.70-3.64(\mathrm{~m}, 1 \mathrm{H}), 3.62-3.57(\mathrm{~m}, 1 \mathrm{H}), 3.54-3.5(\mathrm{~m}$, $1 \mathrm{H}), 3.49-3.44(\mathrm{~m}, 2 \mathrm{H}), 3.43-3.39(\mathrm{~m}, 2 \mathrm{H}), 3.25(\mathrm{br} \mathrm{d}, J=10.1 \mathrm{~Hz}, 1 \mathrm{H}), 3.21(\mathrm{~s}, 3 \mathrm{H}), 3.19(\mathrm{~s}, 2 \mathrm{H}), 3.13-2.96(\mathrm{~m}, 5 \mathrm{H}), 2.93-2.84$ (m, 5H), $2.8(\mathrm{~s}, 3 \mathrm{H}), 2.78-2.65(\mathrm{~m}, 2 \mathrm{H}), 2.64-2.55(\mathrm{~m}, 4 \mathrm{H}), 2.49-2.35(\mathrm{~m}, 4 \mathrm{H}), 2.28-2.2(\mathrm{~m}, 11 \mathrm{H}), 2.16-2.05(\mathrm{~m}, 2 \mathrm{H}), 2.03-1.94$ $(\mathrm{m}, 2 \mathrm{H}), 1.82-1.72(\mathrm{~m}, 1 \mathrm{H}), 1.61(\mathrm{br} \mathrm{dd}, J=10.8,3.2 \mathrm{~Hz}, 2 \mathrm{H}), 1.52-1.37(\mathrm{~m}, 2 \mathrm{H}), 1.24(\mathrm{br} \mathrm{s}, 2 \mathrm{H}), 1.20-1.06(\mathrm{~m}, 27 \mathrm{H}), 1(\mathrm{br} \mathrm{d}, J$ $=7.3 \mathrm{~Hz}, 5 \mathrm{H}), 0.95-0.86(\mathrm{~m}, 6 \mathrm{H}), 0.71-0.68(\mathrm{~m}, 3 \mathrm{H}), 0.64(\mathrm{br} \mathrm{d}, J=6.7 \mathrm{~Hz}, 3 \mathrm{H}), 0.59(\mathrm{~d}, J=6.7 \mathrm{~Hz}, 3 \mathrm{H}), 0.51(\mathrm{~d}, J=6.7 \mathrm{~Hz}, 3 \mathrm{H})$. 
Step a. Cladinose removal
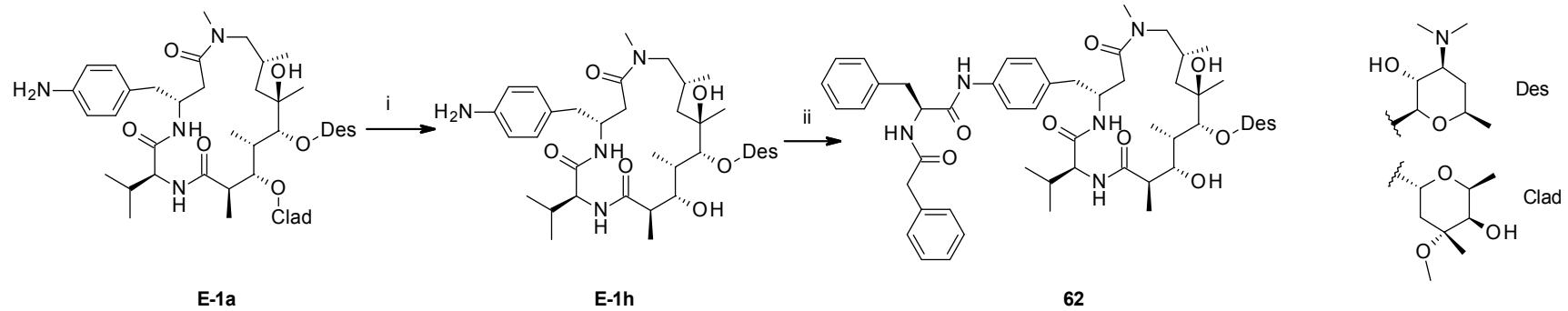

Scheme S9. Synthesis of compound 62

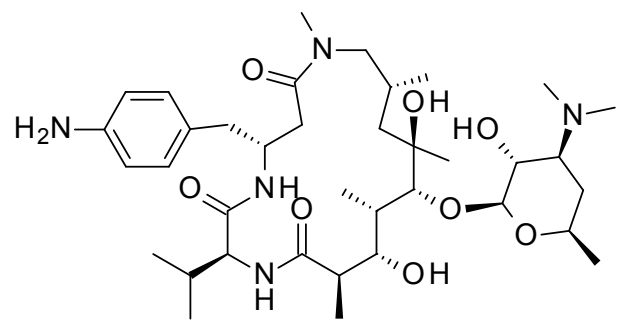

$(2 S, 5 R, 10 R, 12 R, 13 R, 14 S, 15 S, 16 R)-5$-[(4-aminophenyl)methyl]-13-( $\beta$-Ddesosaminyl)oxy-12,15-dihydroxy-2-isopropyl-8,10,12,14,16-pentamethyl1,4,8-triazacycloheptadecane-3,7,17-trione (E-1h)

To the solution of E-1a (260 mg, $0.19 \mathrm{mmol})$ in acetonitrile $(6 \mathrm{~mL})$ was added $6 \mathrm{M} \mathrm{HCl}(11.4 \mathrm{~mL}, 22.8 \mathrm{mmol})$. Reaction mixture was stirred at room temperature overnight. $\mathrm{pH}$ was adjusted to 10 and extracted with DCM (3 x $20 \mathrm{~mL})$. Organic layers were combined and dried $\left(\mathrm{Na}_{2} \mathrm{SO}_{4}\right)$, filtered and concentrated under vacuum to get compound E-1h $(220 \mathrm{mg})$. ES+ m/z 706.56 $[\mathrm{M}+\mathrm{H}]^{+}$.

Step b. Amidation

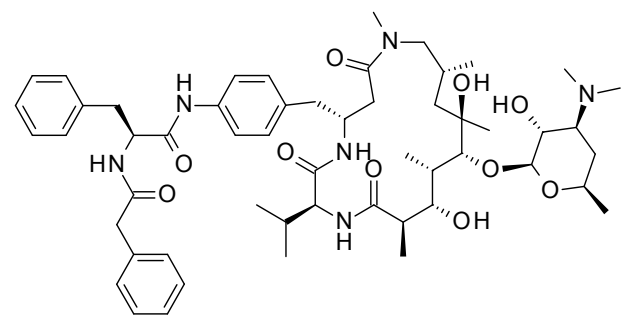

(2S)-3-(2-chlorophenyl)- $N$-[4-[[(2S,5R,10R,12R,13R,14S,15S,16R)-13-( $\beta$-Ddesosaminyl)oxy-12,15-dihydroxy-2-isopropyl-8,10,12,14,16-pentamethyl3,7,17-trioxo-1,4,8-triazacycloheptadec-5-yl]methyl]phenyl]-2-[(2phenylacetyl)amino]propanamide (62)

Following general procedure for step 5 (Scheme S3), starting from 64 (54 mg, $0.17 \mathrm{mmol}$ ) and E-1h (120 mg, $0.17 \mathrm{mmol}$ ) title product was obtained (28 $\mathrm{mg}$, yield $16 \%$, purity $93.6 \%$ ) by prep HPLC purification. $\mathrm{ES}^{+} \mathrm{m} / \mathrm{z} 1005.65$ $[\mathrm{M}+\mathrm{H}]^{+} .{ }^{1} \mathrm{H}$ NMR $\left(500 \mathrm{MHz}, \mathrm{DMSO}-\mathrm{d}_{6}\right) \delta / \mathrm{ppm} 0.46(\mathrm{~d}, 3 \mathrm{H}, J=6.72), 0.55(\mathrm{t}, 2 \mathrm{H}$, $J=5.64,6.42), 0.57(\mathrm{~d}, 3 \mathrm{H}, J=6.66), 0.69-0.71(\mathrm{~m}, 5 \mathrm{H}), 0.78(\mathrm{~d}, 3 \mathrm{H}, J=6.9)$, $0.91(\mathrm{t}, 6 \mathrm{H}, J=5.76,6.36), 1.1(\mathrm{~d}, 6 \mathrm{H}, \mathrm{J}=4.92), 1.14(\mathrm{t}, 9 \mathrm{H}, J=5.88,6.72), 1.2(\mathrm{~d}, 3 \mathrm{H}, J=6.12), 1.2-1.21(\mathrm{~m}, 2 \mathrm{H}) .1 .49-1.52(\mathrm{~m}$, $1 \mathrm{H}), 1.69-1.72(\mathrm{~m}, 4 \mathrm{H}), 1.94-1.99(\mathrm{~m}, 1 \mathrm{H}), 2.06(\mathrm{~d}, 2 \mathrm{H}, J=7.44), 2.16-2.2(\mathrm{~m}, 1 \mathrm{H}), 2.22(\mathrm{~d}, 12 \mathrm{H}, J=7.92), 2.24-2.25(\mathrm{~m}, 1 \mathrm{H})$, 2.42-2.43 (m, 2H), 2.45-2.46 (br. s. 1H), 5.51 (br. s. 1h), 2.54-2.57 (m, 1H), 2.58-2.61 (m, 1H),2.62-2.64 (m, 1H), 2.65-2.69 (m, $1 \mathrm{H}), 2.74(\mathrm{~d}, 3 \mathrm{H}, J=26.46), 2.79(\mathrm{~s}, 3 \mathrm{H}), 2.88-2.9(\mathrm{~m}, 2 \mathrm{H}), 3-3.04(\mathrm{~m}, 2 \mathrm{H}), 3.13-3.19(\mathrm{~m}, 5 \mathrm{H}), 3.4-3.47(\mathrm{~m}, 6 \mathrm{H}), 3.66-3.69(\mathrm{~m}$, $6 \mathrm{H}), 3.95(\mathrm{t}, 1 \mathrm{H}, J=8.16,8.34), 4.18-4.3(\mathrm{~m}, 3 \mathrm{H}), 4.31(\mathrm{~d}, 1 \mathrm{H}, J=7.38), 4.37(\mathrm{dd}, 1 \mathrm{H}, J=7.38,9.06), 4.61(\mathrm{~s}, 1 \mathrm{H}) .4 .75-4.78(\mathrm{~m}$, $3 \mathrm{H}), 4.87(\mathrm{~d}, 1 \mathrm{H}, J=4.98), 5.29(\mathrm{~s}, 1 \mathrm{H}), 5.41(\mathrm{~s}, 1 \mathrm{H}), 6.89(\mathrm{~d}, 1 \mathrm{H}, J=8.7), 7.11-7.14(\mathrm{~m}, 8 \mathrm{H}), 7.16-7.18(\mathrm{~m}, 5 \mathrm{H}), 7.2-7.24(\mathrm{~m}, 6 \mathrm{H})$, 7.26-7.29 (t, 2H, $J=7.32,7.5), 7.36-7.4(\mathrm{~m}, 4 \mathrm{H}), 7.44(\mathrm{~d}, 2 \mathrm{H}, J=8.46), 7.92(\mathrm{~m}, 1 \mathrm{H}), 8.07(\mathrm{~d}, 1 \mathrm{H}, J=8.82), 8.44-8.49(\mathrm{~m}, 2 \mathrm{H})$, $9.91(\mathrm{~s}, 1 \mathrm{H}), 9.97(\mathrm{~s}, 1 \mathrm{H})$. 


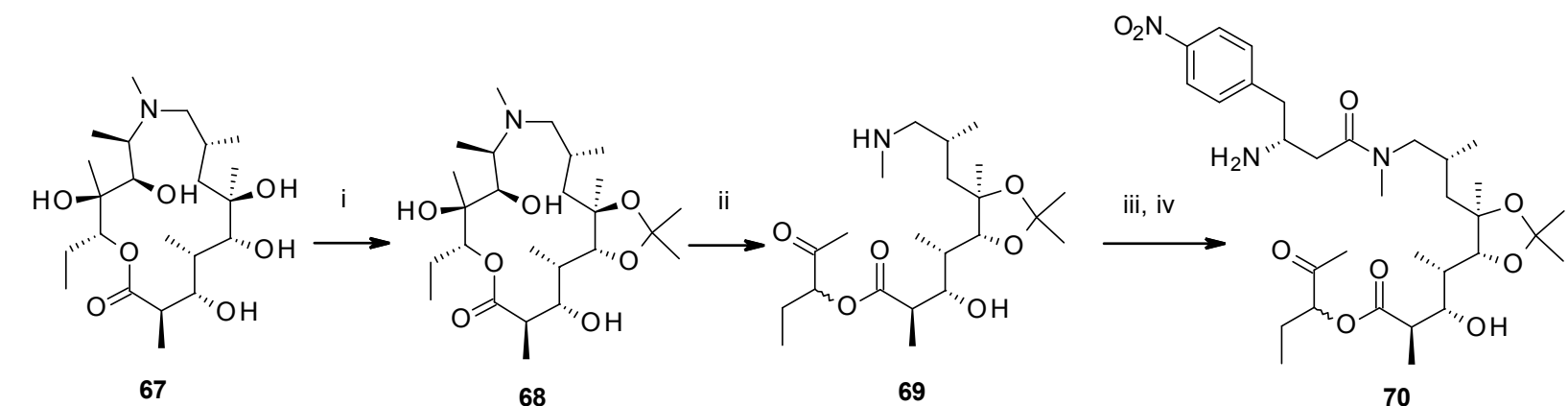

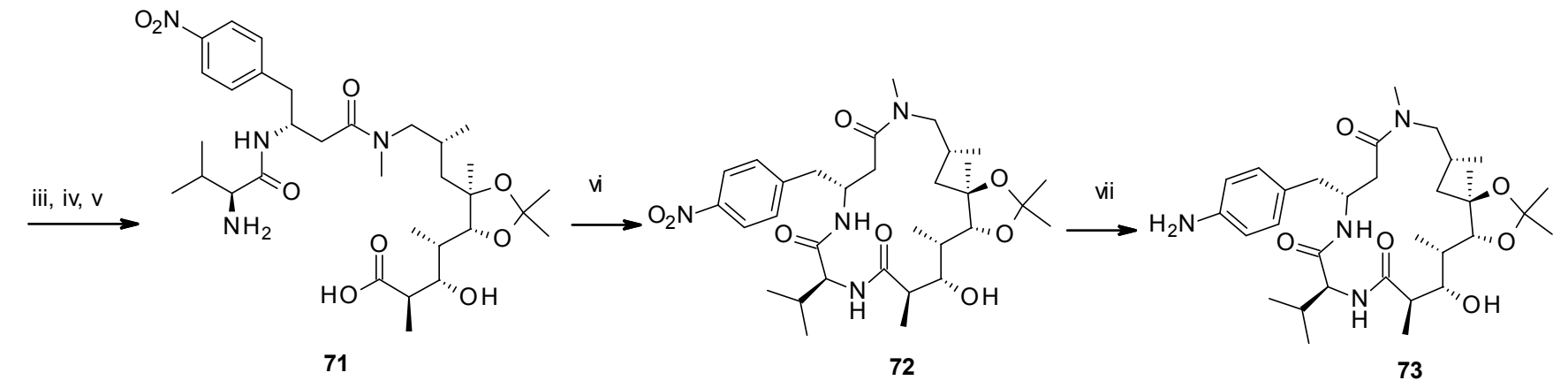

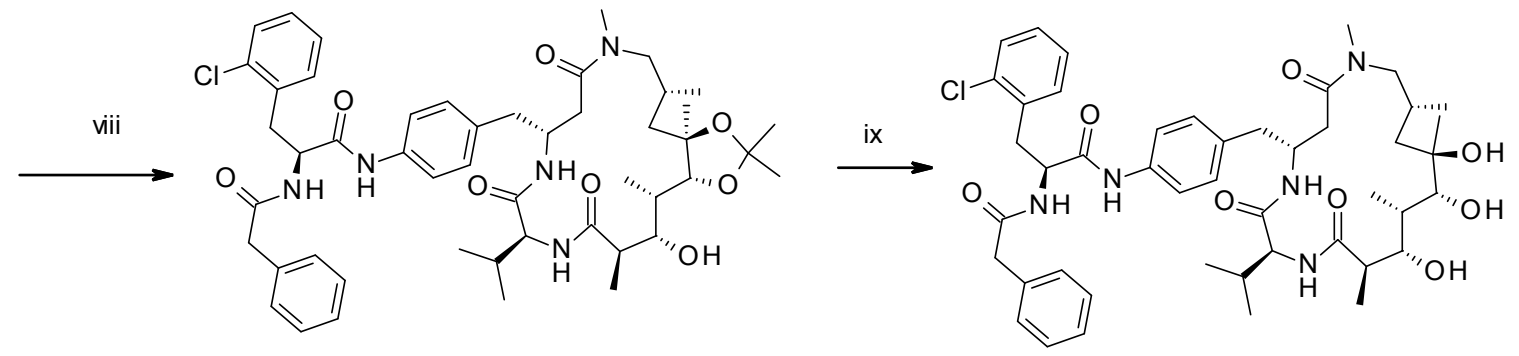

74

63

Scheme S10. Synthesis of compound 63

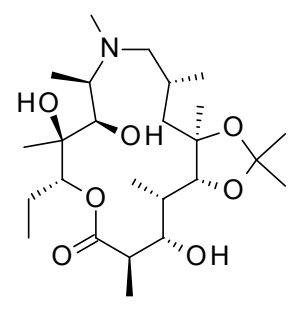

5,6-O-isopropylidene-9a-methyl-9-deoxo-9a-aza-9a-homoerythronolide (68)

Compound $67^{15}$ ( $2 \mathrm{~g}, 4.6 \mathrm{mmol}$ ) was dissolved in dry DCM (40 mL). Rac-camphorsulfonic acid (1.6 g, $6.9 \mathrm{mmol})$ and 2,2-dimethoxypropane $(1.69 \mathrm{~mL}, 13.8 \mathrm{mmol})$ were added. Reaction mixture was stirred at room temperature for $3 \mathrm{~h}$. 2.2-Dimethoxiethane $(0.56 \mathrm{~mL}, 4.6 \mathrm{mmol})$ was added and stirring proceeded for $24 \mathrm{~h}$. Reaction was quenched with sat. aq. $\mathrm{NaHCO}_{3}(40 \mathrm{~mL})$. Layers were separated and aqueous phase was extracted with DCM $(40 \mathrm{~mL})$. Organic extracts were evaporated under reduced pressure to yield the title product as white foam (2.18 g). Analytical sample was purified by flash chromatography and eluted with mixtures of DCM and methanolic ammonia. Title compound was obtained as a white foam. $\mathrm{ES}^{+} \mathrm{m} / \mathrm{z} 474.42[\mathrm{M}+\mathrm{H}]^{+} .{ }^{1} \mathrm{H}-\mathrm{NMR}\left(400 \mathrm{MHz}, \mathrm{DMSO}-\mathrm{d}_{6}\right) \delta / \mathrm{ppm} 4.88(\mathrm{dd}, J=$ $10.4 \mathrm{~Hz}, \mathrm{~J}=2.4 \mathrm{~Hz}, 1 \mathrm{H}) ; 4.42(\mathrm{~d}, J=6.7 \mathrm{~Hz}, 1 \mathrm{H}) ; 4.22$ (bs, $1 \mathrm{H}) ; 4.19(\mathrm{~d}, J=7.2 \mathrm{~Hz}, 1 \mathrm{H}) ; 3.9(\mathrm{t}, J=5.2 \mathrm{~Hz}, 1 \mathrm{H}) ; 3.71(\mathrm{~d}, J=5.6 \mathrm{~Hz}$, $1 \mathrm{H}) ; 3.45(\mathrm{dd}, J=7.5 \mathrm{~Hz}, J=3 \mathrm{~Hz}, 1 \mathrm{H}) ; 2.79(\mathrm{~m}, 1 \mathrm{H}) ; 2.46(\mathrm{~m}, 1 \mathrm{H}) ; 2.28(\mathrm{dd}, J=12.5 \mathrm{~Hz}, J=4 \mathrm{~Hz}, 1 \mathrm{H}) ; 2.18(\mathrm{~s}, 3 \mathrm{H}) ; 2(\mathrm{dd}, J=$ $12.5 \mathrm{~Hz}, J=8.5 \mathrm{~Hz}, 1 \mathrm{H}) ; 1.82(\mathrm{~d}, J=14.6 \mathrm{~Hz}, 1 \mathrm{H}) ; 1.66-1.78(\mathrm{~m}, 3 \mathrm{H}) ; 1.43(\mathrm{~m}, 1 \mathrm{H}) ; 1.3(\mathrm{~s}, 3 \mathrm{H}) ; 1.22(\mathrm{~s}, 3 \mathrm{H}) ; 1.21(\mathrm{~m}, 1 \mathrm{H}) ; 1.24$ $(\mathrm{d}, J=6.9 \mathrm{~Hz}, 3 \mathrm{H}) ; 1.02(\mathrm{~s}, 3 \mathrm{H}) ; 1.01(\mathrm{~s}, 3 \mathrm{H}) ; 0.95(\mathrm{~d}, J=6.8 \mathrm{~Hz}, 6 \mathrm{H}) ; 0.79(\mathrm{t}, J=7.2 \mathrm{~Hz}, 3 \mathrm{H}) ; 0.78(\mathrm{~d}, J=6.6 \mathrm{~Hz}, 3 \mathrm{H}) .{ }^{13} \mathrm{C}-\mathrm{NMR}$ $\left(100\right.$ MHz, DMSO-d $\left.{ }_{6}\right) \delta / p p m ~ 174.0 ; 105.0 ; 82.4 ; 80.7 ; 78.2 ; 75.3 ; 74.6 ; 71.3 ; 62.7 ; 62.4,45.0 ; 42.3,37.5 ; 37.1 ; 28.7 ; 28.1 ; 26.8$; $24.5 ; 22.3 ; 21.4 ; 12.7 ; 11.5 ; 10.0 ; 7.35$.<smiles>CCC(OC(=O)C(C)[C@@H](C)[C@@H](C)[C@H]1OC(C)(C)O[C@@H]1C[C@H](C)CNC)C(C)=O</smiles>

(1-ethyl-2-oxo-propyl)-(2R,3S,4S,5R,6R,8R)-3,5,6-trihydroxy-2,4,6,8-tetramethyl-9(methylamino)nonanoate (69)

Compound 68 (2.2 g, $4.18 \mathrm{mmol}, 90 \%$ purity) was dissolved in chloroform (115 mL). Solution was cooled to $0{ }^{\circ} \mathrm{C}$ and lead(IV) acetate $(2.4 \mathrm{~g}, 5 \mathrm{mmol}, 1.2 \mathrm{eq})$ was added. Reaction mixture was stirred at room temperature for $3 \mathrm{~h}$. Reaction mixture was re-cooled to $0{ }^{\circ} \mathrm{C}$ and lead(IV) acetate (200 mg, $0.4 \mathrm{mmol}, 0.1 \mathrm{eq}$ ) was added and stirring continued for another $2.5 \mathrm{~h}$ at room temperature. The white precipitate formed in the course of the reaction was filtered off and 
washed with chloroform. Filtrate was evaporated and residue was purified by flash chromatography on $\mathrm{SiO}_{2}$ and eluted with DCM:MeOH: $\mathrm{NH}_{4} \mathrm{OH}=$ 90:9:1.5. Title product was obtained as brownish viscous syrup (850 mg, yield 49\%). $\mathrm{ES}^{+} \mathrm{m} / \mathrm{z}=416.39$ $[\mathrm{M}+\mathrm{H}]^{+} .{ }^{1} \mathrm{H}-\mathrm{NMR}(500 \mathrm{MHz}$, DMSO-d 6 ) $\delta / \mathrm{ppm} 4.96(\mathrm{dd}, J=7.3 \mathrm{~Hz}, J=4.7 \mathrm{~Hz}, 1 \mathrm{H}) ; 3.79(\mathrm{~d}, J=9.2 \mathrm{~Hz}, 1 \mathrm{H}) ; 3.61(\mathrm{~d}, J=9.7 \mathrm{~Hz}$, $1 \mathrm{H}) ; 2.59(\mathrm{dq}, J=9.7 \mathrm{~Hz}, J=6.7 \mathrm{~Hz}, 1 \mathrm{H}) ; 2.36(\mathrm{dd}, J=11.8 \mathrm{~Hz}, J=5.1 \mathrm{~Hz}, 1 \mathrm{H}) ; 2.31(\mathrm{dd}, J=11.8 \mathrm{~Hz}, J=8.4 \mathrm{~Hz}, 1 \mathrm{H}) ; 2.3(\mathrm{~s}, 3 \mathrm{H})$; $2.15(\mathrm{~s}, 3 \mathrm{H}) ; 1.72-1.87(\mathrm{~m}, 4 \mathrm{H}) ; 1.69$ (dd, $J=14.8 \mathrm{~Hz}, J=2.4 \mathrm{~Hz}, 1 \mathrm{H}) ; 1.43$ (dd, $J=14.8 \mathrm{~Hz}, J=7.5 \mathrm{~Hz}, 1 \mathrm{H}) ; 1.34(\mathrm{~s}, 3 \mathrm{H}) ; 1.27(\mathrm{~s}$, $3 \mathrm{H}) ; 1.23(\mathrm{~d}, J=6.7 \mathrm{~Hz}, 1 \mathrm{H}) ; 1.06(\mathrm{~s}, 3 \mathrm{H}) ; 1.01(\mathrm{~d}, J=6.5 \mathrm{~Hz}, 1 \mathrm{H}) ; 0.97(\mathrm{~d}, J=6.6 \mathrm{~Hz}, 1 \mathrm{H}) ; 0.91(\mathrm{t}, J=7.5 \mathrm{~Hz}, 1 \mathrm{H}) .{ }^{13} \mathrm{C}-\mathrm{NMR}(125$ MHz, DMSO-d ${ }_{6}$ ) $\delta /$ ppm 204.1; 174.2; 104.5; 87.7; 80.9; 78.9; 69.4; 58.3; 43.4; 43.2; 36.2; 36.1; 28.9; 28.6; 26.7; 26.0; 22.8; $22.7 ; 20.9 ; 15.4 ; 10.2 ; 9.1$.

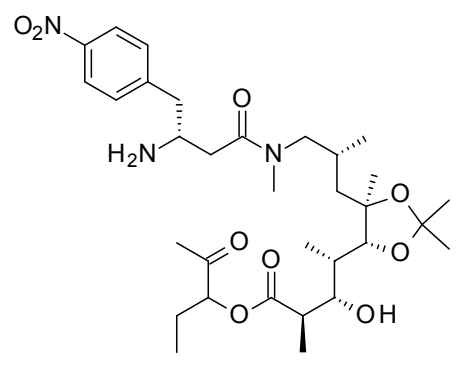

(1-ethyl-2-oxo-propyl)-(2R,3S,4S,5R,6R,8R,13R)-13-amino-3,5,6-trihydroxy-2,4,6,8,105,6-O-isopropylidene-pentamethyl-14-(4-nitrophenyl)-11-oxo-tetradecanoate (70) (3R)-3-(Fmoc-amino)-4-(4-nitrophenyl)butanoic acid (785 $\mathrm{mg}, 1.76 \mathrm{mmol}$ ) was suspended in DCM (10 mL). TMP ( $635 \mu \mathrm{L}, 4 \mathrm{mmol})$, HOAt (109 $\mathrm{mg}, 0.87 \mathrm{mmol})$ and HATU $(640 \mathrm{mg}, 1.76 \mathrm{mmol})$ were added and clear, yellow reaction mixture was stirred at room temperature for $30 \mathrm{~min}$. A solution of $\mathbf{6 9}(640 \mathrm{mg}, 1.6 \mathrm{mmol})$ in DCM was added dropwise and solution was stirred for $3 \mathrm{~h}$ at room temperature. Piperidine ( $925 \mu \mathrm{L}, 9.6 \mathrm{mmol})$ was added and reaction mixture was stirred at room temperature overnight. Reaction mixture was extracted with sat. $\mathrm{NaHCO}_{3}(10 \mathrm{~mL})$ and washed with water $(3 \times 10 \mathrm{~mL})$. Organics were evaporated under reduced pressure and residue was purified by SPE and eluted with mixtures of DCM and methanolic ammonia. Title product was obtained as yellowish foam $(830 \mathrm{mg})$ and used in the next synthetic step without further purification. $\mathrm{ES}^{+} \mathrm{m} / \mathrm{z} 622.45[\mathrm{M}+\mathrm{H}]^{+}$.

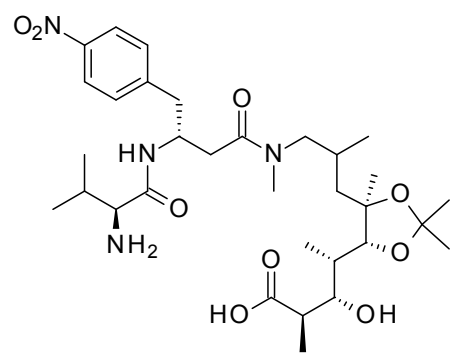

$(2 R, 3 S, 4 S, 5 R, 6 R, 8 R, 13 R, 16 S)$-16-amino-13-[(4-nitrophenyl)methyl]-3,5,6-trihydroxy5,6-O-isopropylidene-2,4,6,8,10,17-hexamethyl-11,15-dioxo-10,14-diaza-octadecanoic acid (71)

Fmoc- $(S)$-Val (500 mg, $1.47 \mathrm{mmol})$ was suspended in DCM $(10 \mathrm{~mL})$. TMP (532 $\mu \mathrm{L}, 3.35$ $\mathrm{mmol}$ ), HOAt ( $91 \mathrm{mg}, 0.64 \mathrm{mmol}$ ) and HATU ( $560 \mathrm{mg}, 1.47 \mathrm{mmol}$ ) were added and clear, yellow reaction mixture was stirred at room temperature for $30 \mathrm{~min}$. A solution of $\mathbf{7 0}$ (830 $\mathrm{mg}, 1.34 \mathrm{mmol})$ in DCM $(10 \mathrm{~mL})$ was added dropwise and solution was stirred for $1.5 \mathrm{~h}$ at room temperature. Piperidine $(775 \mu \mathrm{L}, 8 \mathrm{mmol})$ was added and reaction mixture was stirred at room temperature overnight. After complete Fmoc deprotection reaction mixture was washed with sat. $\mathrm{NaHCO}_{3}(10 \mathrm{~mL})$ and water $(3 \times 10 \mathrm{~mL})$. Solvent was removed under reduced pressure and residue was dissolved in THF. A solution of LiOH (270 mg, $6.7 \mathrm{mmol})$ in water ( $2 \mathrm{~mL})$ was added and reaction mixture was stirred at room temperature for $1 \mathrm{~h}$. Reaction mixture was neutralised with sat. $\mathrm{KH}_{2} \mathrm{PO}_{4}$ and solvent removed under reduced pressure. Residue was extracted with acetone $(3 \times 20 \mathrm{~mL})$. Solids were filtered off while filtrate was evaporated and residue was purified by SPE and eluted with mixture of DCM and methanolic ammonia. Title product was obtained as yellow foam $\left(500 \mathrm{mg}\right.$ ) that was used in the next synthetic step without further purification. $\mathrm{ES}^{+} \mathrm{m} / \mathrm{z}$ $637.44[\mathrm{M}+\mathrm{H}]^{+}$.

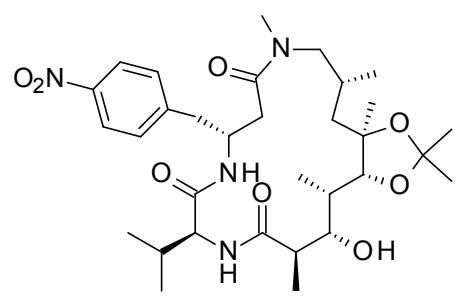

$(2 S, 5 R, 10 R, 12 R, 13 R, 14 S, 15 S, 16 R)$-12,13,15-trihydroxy-2-isopropyl-12,13-Oisopropylidene-8,10,12,14,16-pentamethyl-5-[(4-nitroophenyl) methyl]-1,4,8triazacycloheptadecane-3,7,17-trione (72)

A flask was charged under argon with HATU ( $355 \mathrm{mg}, 0.94 \mathrm{mmol}$ ), DMF (1 mL) and DIPEA (150 $\mu$ l, $0.86 \mathrm{mmol})$. Reaction mixture turned orange-brown. 71 (496 mg, $0.78 \mathrm{mmol}$ ) was dissolved in DMF ( $2 \mathrm{~mL}$ ) and this solution was added via syringe pump to the solution of the coupling reagents ( $35 \mu \mathrm{L} / \mathrm{min})$. Reaction mixture was stirred at room temperature for $4 \mathrm{~h}$. Reaction was quenched with sat. $\mathrm{NaHCO}_{3}(10 \mathrm{~mL})$ and mixture was extracted with DCM $(3 \times 10 \mathrm{~mL})$. Combined organics were washed with water $(3 \times 10 \mathrm{~mL})$ and solvent removed under reduced pressure. The residue was purified by SPE on $\mathrm{SiO}_{2}$ and eluted with mixtures of cyclohexane:EtOAc (0-60 \%). Title product was obtained as yellow foam (165 mg, $34 \%)$. ES ${ }^{+} \mathrm{m} / \mathrm{z} 619.43[\mathrm{M}+\mathrm{H}]^{+}$.

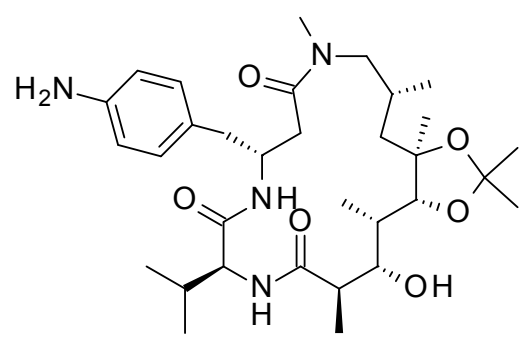

$(2 S, 5 R, 10 R, 12 R, 13 R, 14 S, 15 S, 16 R)-5-[(4-a m i n o p h e n y l) m e t h y l]-12,13,15-$ trihydroxy-2-isopropyl-12,13-O-isopropylidene-8,10,12,14,16-pentamethyl-1,4,8triazacycloheptadecane-3,7,17-trione (73)

Compound 72 (160 mg, $0.26 \mathrm{mmol}$ ) was dissolved in EtOAc ( $3 \mathrm{~mL})$. Ammonium formate $(82 \mathrm{mg}, 1.3 \mathrm{mmol})$ and palladium on carbon $(15 \mathrm{mg})$ were added and reaction mixture was stirred at $100{ }^{\circ} \mathrm{C}$ in a $\mathrm{MW}$ reactor for $35 \mathrm{~min}$. Catalyst was filtered off and new portions of ammonium formate $(82 \mathrm{mg}, 1.3 \mathrm{mmol})$ and palladium on carbon (15 mg) were added. Reaction was performed under the above mentioned conditions for 20 min more. Solids were filtered off and filtrate evaporated to dryness. Crude product thus obtained (130 mg) was used in the next synthetic step without further purification. $\mathrm{ES}^{+} \mathrm{m} / \mathrm{z} 589.43[\mathrm{M}+\mathrm{H}]^{+}$. 


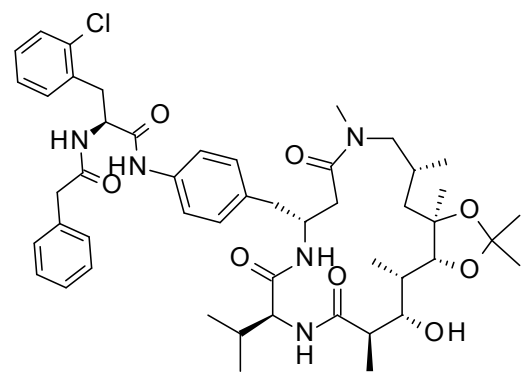

$(2 S, 5 R, 10 R, 12 R, 13 R, 14 S, 15 S, 16 R)-5-[[44-[[(2 S)-3-(2-c h l o r o p h e n y l)-2-[(2-$ phenylacetyl)amino]propanoyl]amino]phenyl]methyl]-12,13,15-trihydroxy-2isopropyl-12,13-O-isopropylidene-8,10,12,14,16-pentamethyl-1,4,8triazacycloheptadecane-3,7,17-trione (74) Compound 73 (126 mg, $0.21 \mathrm{mmol}$ ) was dissolved in DMF (1 mL). 64 (73 mg, 0.23 mmol), DIPEA (71 $\mu \mathrm{L}, 0.42 \mathrm{mmol})$ and HATU (104 mg, $0.27 \mathrm{mmol}$ ) were added and yellow reaction mixture was stirred at room temperature for $1.5 \mathrm{~h}$. Reaction was quenched with sat. NaHCO3 $(10 \mathrm{~mL})$ and extracted with DCM $(10+2 \times 5 \mathrm{~mL})$, combined organics were washed with water $(3 \times 5 \mathrm{~mL})$ and solvent evaporated under reduce pressure. Residue was preabsorbed on SiO2 and purified by SPE on $\mathrm{SiO} 2$ (2 g) and eluted with mixtures of DCM and methanolic ammonia (0-2.4 \%, 0.6 \% step, $25 \mathrm{~mL}$ each, $3 \%, 100 \mathrm{~mL}$ ). Title product was obtained as off-white foam $150 \mathrm{mg}$. A sample (25 mg,) was purified by prep HPLC-MS (purity $96.2 \%$ ). ES+ m/z 888.21/890.21 [M+H]+,

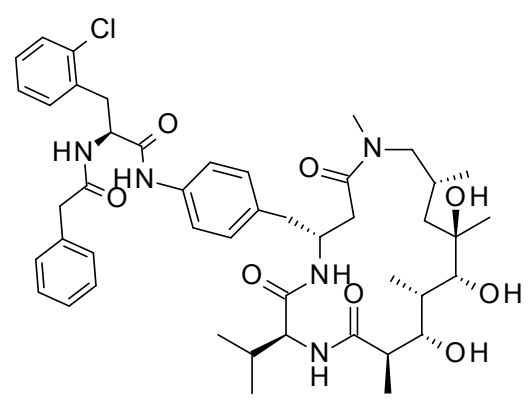

$(2 S, 5 R, 10 R, 12 R, 13 R, 14 S, 15 S, 16 R)-5-[[4-[[(2 S)-3-(2-$ chlorophenyl)-2-[(2phenylacetyl)amino]propanoyl]amino]phenyl]methyl]-12,13,15-trihydroxy-2isopropyl-8,10,12,14,16-pentamethyl-1,4,8-triazacycloheptadecane-3,7,17-trione (63)

Compound 74 (124 mg, $0.14 \mathrm{mmol}$ ) was dissolved in THF (2 mL). 1N HCl (2 mL) was added and reaction mixture was stirred at room temperature for $4 \mathrm{~h}$. After neutralisation with $1 \mathrm{~N} \mathrm{NaOH}$ it was extracted with DCM $(3 \times 5 \mathrm{~mL})$. Combined organics were washed with water $(3 \times 5 \mathrm{~mL})$ and brine $(5 \mathrm{~mL})$. Solvent was removed under reduced pressure and residue was purified by prep HPLC-MS. Title product was obtained as white powder (35 mg, purity $91.9 \%$ ). $\mathrm{ES}^{+} \mathrm{m} / \mathrm{z}$ 848.39/850.4 $[\mathrm{M}+\mathrm{H}]^{+}$. Two sets of signals in the NMR (most likely conformers). ${ }^{1} \mathrm{H}-\mathrm{NMR}(500 \mathrm{MHz}$, DMSO-d $)_{6} \delta: 4.96(\mathrm{dd}, J=7.3 \mathrm{~Hz}, J=4.7 \mathrm{~Hz}, 1 \mathrm{H}) ; 3.79(\mathrm{~d}, J=9.2 \mathrm{~Hz}, 1 \mathrm{H}) ; 3.61(\mathrm{~d}, J=9.7 \mathrm{~Hz}, 1 \mathrm{H}) ; 2.59(\mathrm{dq}, J=9.7 \mathrm{~Hz}, J=6.7 \mathrm{~Hz}$, $1 \mathrm{H}) ; 2.36(\mathrm{dd}, J=11.8 \mathrm{~Hz}, J=5.1 \mathrm{~Hz}, 1 \mathrm{H}) ; 2.31(\mathrm{dd}, J=11.8 \mathrm{~Hz}, J=8.4 \mathrm{~Hz}, 1 \mathrm{H}) ; 2.3(\mathrm{~s}, 3 \mathrm{H}) ; 2.15(\mathrm{~s}, 3 \mathrm{H}) ; 1.72-1.87(\mathrm{~m}, 4 \mathrm{H}) ; 1.69$ $(\mathrm{dd}, J=14.8 \mathrm{~Hz}, J=2.4 \mathrm{~Hz}, 1 \mathrm{H}) ; 1.43(\mathrm{dd}, J=14.8 \mathrm{~Hz}, J=7.5 \mathrm{~Hz}, 1 \mathrm{H}) ; 1.34(\mathrm{~s}, 3 \mathrm{H}) ; 1.27(\mathrm{~s}, 3 \mathrm{H}) ; 1.23(\mathrm{~d}, J=6.7 \mathrm{~Hz}, 1 \mathrm{H}) ; 1.06(\mathrm{~s}$, $3 \mathrm{H}) ; 1.01(\mathrm{~d}, J=6.5 \mathrm{~Hz}, 1 \mathrm{H}) ; 0.97(\mathrm{~d}, J=6.6 \mathrm{~Hz}, 1 \mathrm{H}) ; 0.91(\mathrm{t}, J=7.5 \mathrm{~Hz}, 1 \mathrm{H})$. 


\section{REFERENCES}

(1) Villar, E. A.; Beglov, D.; Chennamadhavuni, S.; Porco, J. A. Jr; Kozakov, D.; Vajda, S.; Whitty, A. How proteins bind macrocycles. Nat. Chem. Biol. 2014, 10(9), 723-731.

(2) Giordanetto, F.; Kihlberg, J. Macrocyclic Drugs and Clinical Candidates: What Can Medicinal Chemists Learn from Their Properties? J. Med. Chem. 2014, 57(2), 278-295.

(3) Ting, J. P.; Tung, F.; Antonysamy, S.; Wasserman, S.; Jones, S. B.; Zhang, F. F.; Espada, A.; Broughton, H.; Chalmers, M. J.; Woodman, M. E.; Holly A. Bina, Dodge, J. A.; Benach, J.; Zhang, A.; Groshong, C.; Manglicmot, D.; Russell, M.; Afshar, S. Utilization of peptide phage display to investigate hotspots on IL-17A and what it means for drug discovery. PLoS One. 2018, 13, e0190850/1-e0190850/18.

(4) Liu, S.; Dakin, L. A.; Xing, L.; Withka, J. M.; Sahasrabudhe, P. V.; Li, W.; Banker, M. E.; Balbo, P.; Shanker, S.; Chrunyk, B. A.; Guo, Z.; Chen, J. M.; Young, J. A.; Bai, G.; Starr, J. T.;Wright, S. W.; Bussenius, J.; Tan, S.; Gopalsamy, A.; Lefker, B. A.; Vincent, F.; Jones, L. H.; Xu, H.; Hoth, L. R.; Geoghegan, K. F.; Qiu, X.; Bunnage, M. E.; Thorarensen, A. Binding site elucidation and structure guided design of macrocyclic IL-17A antagonists. Sci. Rep. 2016, 6, 30859.

(5) Berman, H. M.; Westbrook, J.; Feng, Z.; Gilliland, G.; Bhat, T. N.; Weissig, H.; Shindyalov, I. N.; Bourne, P. E. The Protein Data Bank. Nucleic Acids Res. 2000, 28, 235-242.

(6) Friesner, R. A.; Murphy, R. B.; Repasky, M. P.; Frye, L. L.; Greenwood, J. R.; Halgren, T. A.; Sanschagrin, P. C.; Mainz, D. T. Extra precision Glide: docking and scoring incorporating a model of hydrophobic enclosure for protein-ligand complexes. J. Med. Chem. 2006, 49, 6177-6196.

(7) Friesner, R. A.; Banks, J. L.; Murphy, R. B.; Halgren, T. A.; Klicic, J. J.; Mainz, D. T.; Repasky, M. P.; Knoll, E. H.; Shaw, D. E.; Shelley, M.; Perry, J. K.; Francis, P.; Shenkin, P. S. Glide: A new approach for rapid, accurate docking and scoring. 1. Method and assessment of docking accuracy. J. Med. Chem. 2004, 47, 1739-1749.

(8) Schrödinger Release 2018-1: Maestro, Schrödinger, LLC, New York, NY, 2018.

(9) Li, J.; Abel, R.; Zhu, K.; Cao, Y.; Zhao, S.; Friesner, R. A. The VSGB 2.0 model: A next generation energy model for high resolution protein structure modelling. Proteins. 2011, 79, 2794-2812.

(10) Shivakumar, D.; Williams, J.; Wu, Y.; Damm, W.; Shelley, J.; Sherman, W. Prediction of absolute solvation free energies using molecular dynamics free energy perturbation and the OPLS force field. J. Chem. Theory Comput. 2010, 6, 1509-1519.

(11) Harder, E.; Damm, W.; Maple, J.; Wu, C.; Reboul, M.; Xiang, J. Y.; Wang, L.; Lupyan, D.; Dahlgren, M. K.; Knight, J. L.; Kaus, J. W.; Cerutti, D.; Krilov, G.; Jorgensen, W. L.; Abel, R.; Friesner, R. A. OPLS3: a force field providing broad coverage of drug-like small molecules and proteins. J. Chem. Theory Comput. 2016, 12, 281-296.

(12) Taylor M.; Terrett, N. K.; Connors, W. H.; Shortsleeves, K. C.; Seigal, B. A.; Snedeker, C.; Hale, S. P.; Briggs, T. F.; Favaloro, F. G.; Cipriani, T. J.; Yan, D; Alexander, S. L.; Thorarensen, A.; Xing, L. Preparation of Macrocyclic Compounds as IL-17 Modulators. Int. Pat. Appl. W02013116682A1, 2013.

(13) Nožinić, D.; Milić, A.; Mikac, L.; Ralić, J.; Padovan, J.; Antolović, R. Assessment of macrolide transport using PAMPA, Caco-2 and MDCKII-hMDR1 assays. Croat. Chem. Acta. 2010, 83, 323-331.

(14) Piper, D. R.; Duff, S. R.; Eliason, H. C.; Frazee, W. J.; Frey, E. A.; Fuerstenau-Sharp, M.; Jachec, C.; Marks, B. D.; Pollok, B. A.; Shekhani, M. S.; Thompson, D. V.; Whitney, P.; Vogel, K. W.; Hess. S. D. Development of the Predictor hERG Fluorescence Polarization Assay Using a Membrane Protein Enrichment Approach. Assay Drug Dev. Techn. 2008, 6, 213-223.

(15) Djokić, S; Kobrehel, G.; Lopotar, N.; Kamenar, B.; Nagl, A.; Mrvos, D., Erythromycin series. Part 13. Synthesis and structure elucidation of 10-dihydro-10-deoxo-11-methyl-11-azaerythromycin A. J. Chem. Res. Synopses. 1988, 5, 152-153. 